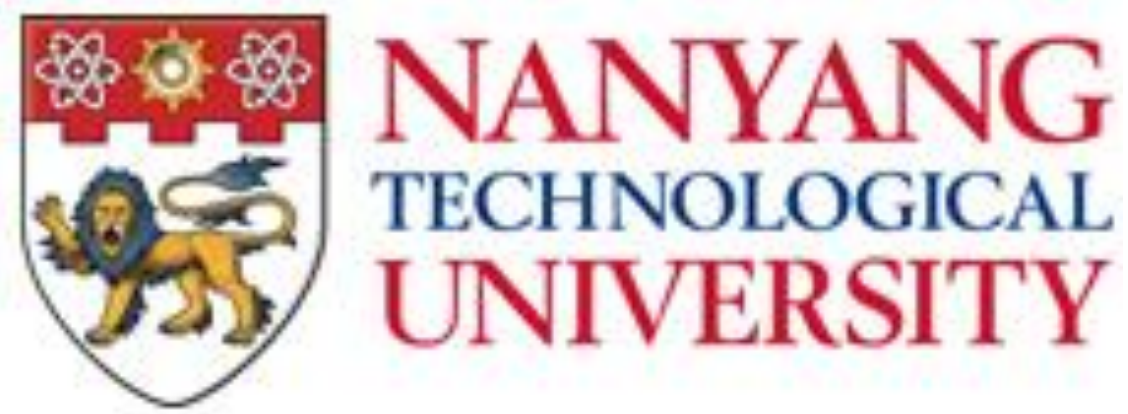

DEVELOPMENT OF PHOSPHAPALLADACYCLES

AS POTENTIAL CATALYSTS

FOR ASYMMETRIC SYNTHESIS

CHIEW JUN XUAN

SCHOOL OF PHYSICAL AND MATHEMATICAL SCIENCES 


\section{DEVELOPMENT OF PHOSPHAPALLADACYCLES AS POTENTIAL CATALYSTS \\ FOR ASYMMETRIC SYNTHESIS}

\section{CHIEW JUN XUAN}

B.Sc. (Hons)

School of Physical and Mathematical Sciences

A thesis submitted to the Nanyang Technological University in partial fulfilment of the requirement for the degree of Doctor of Philosophy 


\section{Acknowledgements}

I would like to express my sincere gratitude to my supervisor, Professor Leung Pak-Hing, for his patient guidance and support throughout the course of my study.

I would like to thank Dr. Sumod A. Pullarkat for his care and concern, frequently enquiring about my progress.

My heartfelt thanks go to Dr. Chen Shuli whose advice and encouragement inspired me to further my studies, and Dr. Huang Yinhua whose invaluable assistance during the early stages of my work helped me to get on track. I thank my laboratory mates Kennard, Xiangyuan, Binbin, Yuxiang, Jonathan, Jeremy, Esther and Xirui for lending their helping hands.

I would like to thank Dr. Li Yongxin and Dr. Rakesh Ganguly for their help in carrying out the X-ray crystallographic studies. I appreciate Ms Goh Ee Ling and Ms Pui Pang Yi for their technical support in NMR and elemental analysis.

I am grateful to Nanyang Technological University for the award of a research scholarship.

Last but not least, I am very grateful for the unconditional love and support of my family and friends, especially my mother, without whom the pursuance of my PhD study would have been impossible. 


\section{Table of Contents}

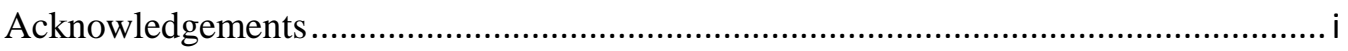

Abbreviations and Symbols ….............................................................................. iv

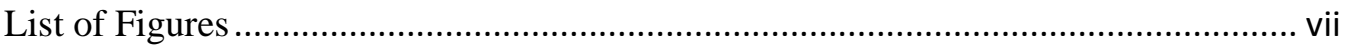

List of Tables ......................................................................................................... vii

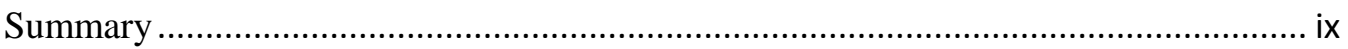

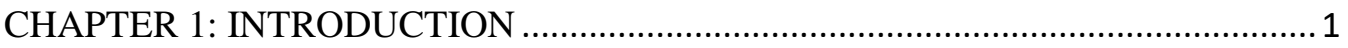

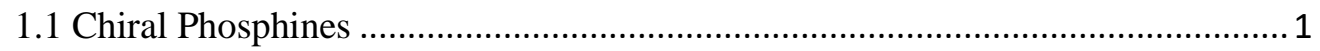

1.1.1 Methods of Preparation of Chiral Phosphines ........................................... 2

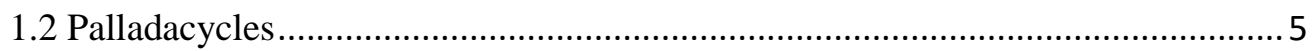

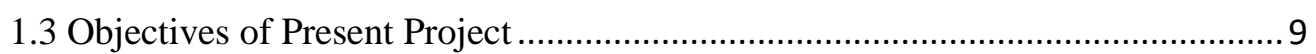

CHAPTER 2: CYCLOPALLADATION OF 1-[(2,5-

DIISOPROPYLPHENYL)ETHYL]DIPHENYLPHOSPHINE .................................. 11

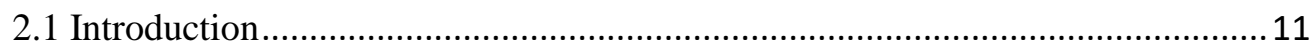

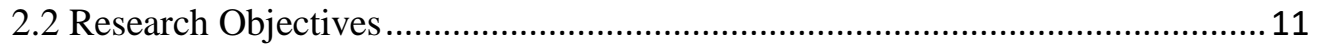

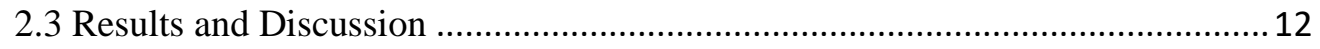

2.3.1 Synthesis of the racemic phosphine ligand 11 ....................................... 12

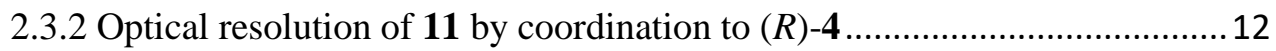

2.3.3 Removal of naphthylamine auxiliary and ortho-palladation........................14

2.3.4 Coordination to $\mathbf{1}$ and cyclopalladation of $\mathbf{1 1}$............................................ 15

2.3.5 Coordination of $(S, S)$-14 with triphenylphosphine and dppe ...................... 16

2.3.6 Use of bis(acetonitrile) complex of $(S, S)-\mathbf{1 4}$ in promoting asymmetric

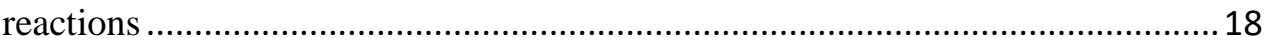

2.3.6.1 Asymmetric hydrophosphination reaction of trans-chalcone ................... 19

2.3.6.2 Asymmetric synthesis of P-chiral diarylphosphinites .............................. 19

2.3.6.2.1 (9-Phenanthryl)phenylphosphine with 2,5-diphenylbenzoquinone ....... 20

2.3.6.2.2 (1-Naphthyl)phenylphosphine with 2,5-diphenylbenzoquinone ............ 22

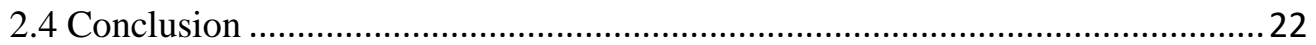

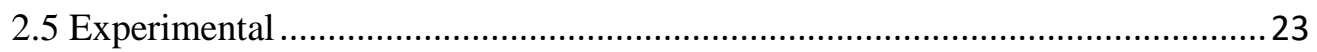


CHAPTER 3: SYNTHESIS OF CP-PALLADACYCLES FROM CHIRAL PHOSPHINES VIA CATALYTIC ASYMMETRIC HYDROPHOSPHINATION

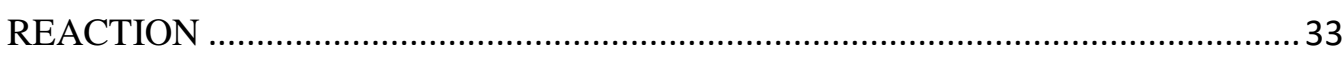

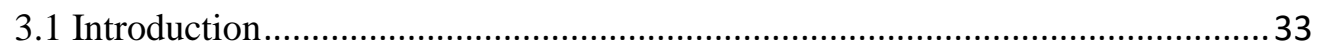

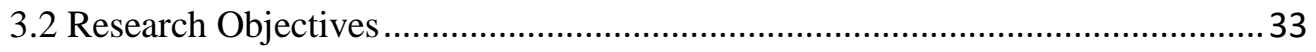

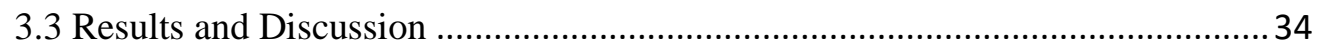

3.3.1.1 Asymmetric catalytic hydrophosphination reaction with

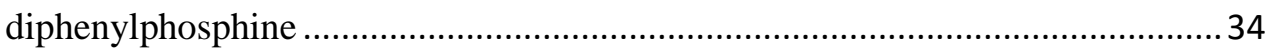

3.3.1.2 Coordination to $(R)-4$ and cyclopalladation of 29................................... 35

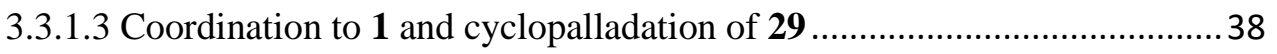

3.3.1.4 Coordination of $(S, S)$-32 with triphenylphosphine and dppe ................... 40

3.3.2.1 Asymmetric catalytic hydrophosphination reaction with $o$ -

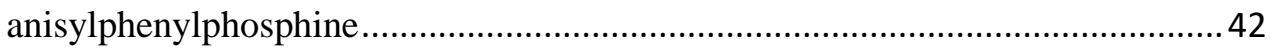

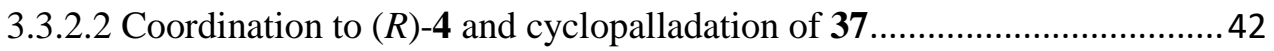

3.3.2.3 Coordination to $\mathbf{1}$ and cyclopalladation of $\mathbf{3 7}$........................................ 46

3.3.2.4 Coordination of $\left(S_{\mathrm{C}}, S_{\mathrm{P}}, S_{\mathrm{C}}, S_{\mathrm{P}}\right)-\mathbf{4 0}$ with triphenylphosphine and dppe ...... 50

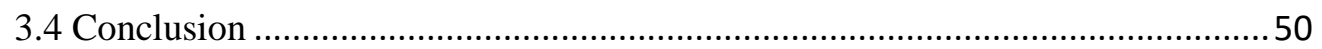

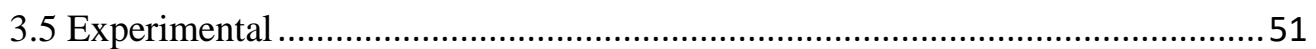

CHAPTER 4: ASYMMETRIC SYNTHESIS OF ISOQUINOLINE-BASED CHIRAL

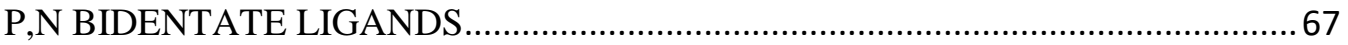

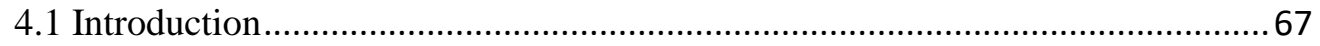

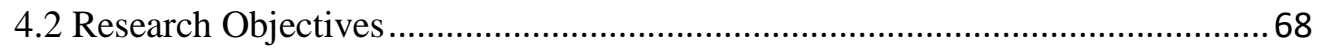

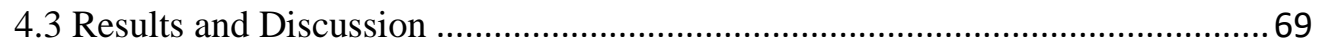

4.3.1.1 Asymmetric hydrophosphination with diphenylphosphine promoted by

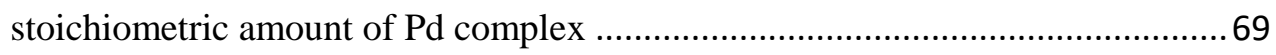

4.3.1.2 Catalytic asymmetric hydrophosphination with diphenylphosphine promoted by catalytic amount of Pd complex...................................................... 73

4.3.2.1 Asymmetric hydrophosphination with $o$-anisylphenylphosphine promoted by stoichiometric amount of Pd complex ...................................................... 74

4.3.2.2 Catalytic asymmetric hydrophosphination with $o$-anisylphenylphosphine promoted by catalytic amount of Pd complex................................................... 77

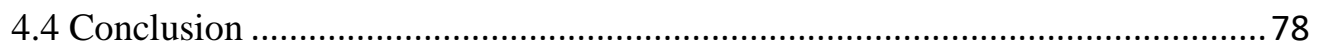

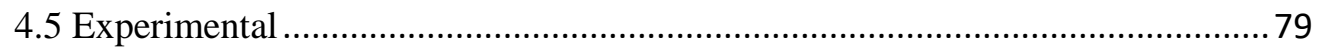

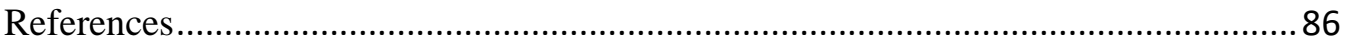

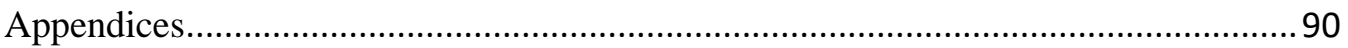




\section{Abbreviations and Symbols}

\begin{tabular}{|c|c|}
\hline Ad & adamantyl \\
\hline An & anisoyl \\
\hline $\mathrm{Ar}$ & aryl \\
\hline $\mathrm{Bn}$ & benzyl \\
\hline $\mathrm{Bu}$ & butyl \\
\hline$c a$. & about (Latin $\operatorname{circa}$ ) \\
\hline calcd & calculated \\
\hline conc. & concentrated \\
\hline $\mathrm{Cp}$ & cyclopentadienyl \\
\hline CSA & 10-camphorsulfonic acid \\
\hline $\mathrm{Cy}$ & cyclohexyl \\
\hline $\mathrm{d}$ & doublet, day(s) \\
\hline $\mathrm{dba}$ & trans,trans-dibenzylideneacetone \\
\hline DBTA & dibenzoyltartaric acid \\
\hline DBU & 1,8-diazabicyclo[5.4.0]undec-7-ene \\
\hline DCM & dichloromethane \\
\hline dd & doublet of a doublet \\
\hline ddd & doublet of a doublet of a doublet \\
\hline de & diastereomeric excess \\
\hline dec & decomposed \\
\hline $\operatorname{deg}$ & degree(s) \\
\hline $\mathrm{dm}$ & decimeter \\
\hline DMPP & 3,4-dimethyl-1-phenylphosphole \\
\hline dppe & 1,2-bis(diphenylphosphino)ethane \\
\hline
\end{tabular}




\begin{tabular}{|c|c|}
\hline $\mathrm{dr}$ & diastereomeric ratio \\
\hline ee & enantiomeric excess \\
\hline eq & equatorial \\
\hline equiv. & equivalent \\
\hline Et & ethyl \\
\hline et. al. & and others (Latin alii) \\
\hline $\mathrm{g}$ & $\operatorname{gram}(\mathrm{s})$ \\
\hline $\mathrm{h}$ & hour(s) \\
\hline Hex & hexyl \\
\hline $\mathrm{Hz}$ & hertz \\
\hline i.e. & that is (Latin id est) \\
\hline $\mathrm{i}$ & iso \\
\hline IPA & isopropyl alcohol \\
\hline$J$ & coupling constant \\
\hline $\mathrm{m}$ & multiplet \\
\hline$m$ & meta \\
\hline $\mathrm{Me}$ & methyl \\
\hline Men & menthyl \\
\hline $\min$ & minute(s) \\
\hline $\mathrm{mp}$ & melting point \\
\hline $\operatorname{MS}(\mathrm{ESI})$ & Mass Spectrometry (Electrospray Ionization) \\
\hline $\mathrm{MS}(\mathrm{FAB})$ & Mass Spectrometry (Fast Atom Bombardment) \\
\hline$n$ & straight chain \\
\hline NMR & Nuclear Magnetic Resonance \\
\hline NOE & Nuclear Overhauser Effect \\
\hline
\end{tabular}




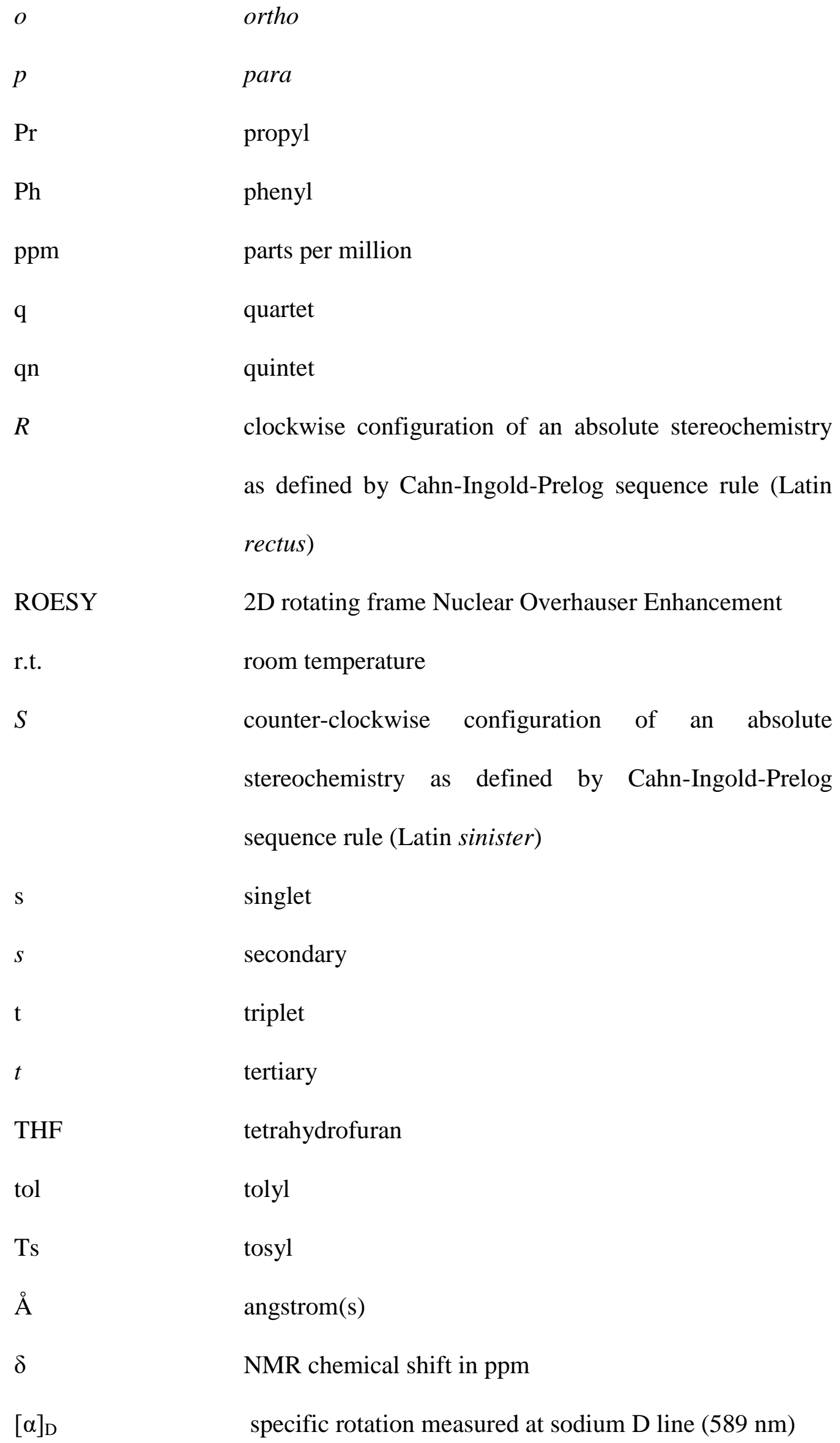




\section{List of Figures}

Figure 1.1 Examples of chiral phosphines $\quad 2$

Figure 2.1 X-ray molecular structure of $(R, S)$-12 13

$\begin{array}{ll}\text { Figure 2.2 X-ray molecular structure of }(S)-\mathbf{1 8} & 17\end{array}$

Figure 2.3 X-ray molecular structure of rac-24 21

Figure 3.1 X-ray molecular structure of $(R, S)$-30 37

Figure 3.2 ${ }^{31} \mathrm{P}\left\{{ }^{1} \mathrm{H}\right\}$ NMR spectrum of $(S)-35\left(\mathrm{CDCl}_{3}, 202 \mathrm{MHz}\right)$

Figure 3.3 ${ }^{31} \mathrm{P}\left\{{ }^{1} \mathrm{H}\right\}$ NMR spectrum of $\mathbf{4 1}\left(\mathrm{CDCl}_{3}, 202 \mathrm{MHz}\right)$

Figure 3.4 X-ray molecular structure of cis-rac-41 45

Figure 3.5 X-ray molecular structure of $(Z)-\left(S_{\mathrm{C}}, S_{\mathrm{P}}, S_{\mathrm{N}}\right)-\mathbf{4 3}$

Figure 4.1 X-ray molecular structure of $(R, S)-46 \quad 70$

Figure 4.2 X-ray molecular structure of $\mathrm{rac}-\mathbf{4 7} \quad 72$

Figure 4.3 X-ray molecular structure of $\left(R, R_{\mathrm{C}}, R_{\mathrm{P}}\right)-\mathbf{5 0} \quad 75$ 


\section{List of Tables}

Table 2.1 Selected bond lengths $(\AA)$ and angles $\left({ }^{\circ}\right)$ of $(R, S)-12 \quad 13$

Table 2.2 Selected bond lengths $(\AA)$ and angles $\left({ }^{\circ}\right)$ of $(S)-\mathbf{1 8} \quad 18$

Table 2.3 Screening of reaction conditions for the formation of $24 \quad 20$

Table 2.4 Selected bond lengths $(\AA)$ and angles $\left(^{\circ}\right)$ of $\mathrm{rac}-\mathbf{2 4} 21$

Table 2.5 Screening of reaction conditions for the formation of $27 \quad 22$

Table 3.1 Screening of reaction conditions for the formation of 29

Table 3.2 Selected bond lengths $(\AA)$ and angles $\left(^{\circ}\right)$ of $(R, S)-30$

Table 3.3 Screening of reaction conditions for the formation of $37 \quad 42$

Table 3.4 Selected bond lengths $(\AA)$ and angles $\left({ }^{\circ}\right)$ of $c i s-r a c-41$

Table 3.5 Selected bond lengths $(\AA)$ and angles $\left({ }^{\circ}\right)$ of $(Z)-\left(S_{\mathrm{C}}, S_{\mathrm{P}}, S_{\mathrm{N}}\right)-\mathbf{4 3} \quad 49$

Table 4.1 Selected bond lengths $(\AA)$ and angles $\left({ }^{\circ}\right)$ of $(R, S)-\mathbf{4 6} \quad 70$

Table 4.2 Selected bond lengths $(\AA)$ and angles $\left(^{\circ}\right)$ of rac-47 72

Table 4.3 Selected bond lengths $(\AA)$ and angles $\left({ }^{\circ}\right)$ of $\left(R, R_{\mathrm{C}}, R_{\mathrm{P}}\right)-\mathbf{5 0} \quad 75$ 


\section{Summary}

This thesis describes the design and synthesis of chiral phosphapalladacycles and their applications in catalytic asymmetric reactions.

An introduction on the syntheses and applications of chiral phosphines and phosphapallacycles, as well as the research development and the objective of this project were presented in Chapter 1.

Chapter 2 describes the synthesis of a 5-membered ortho-palladated complex derived from the chiral ligand 1-(2', 5'diisopropylphenyl)ethyldiphenylphosphine. The phosphine was synthesized as a racemate by treating 1-chloro-1-(2', 5'-diisopropylphenyl)ethane with sodium diphenylphosphide. The ligand was optically resolved using the naphthylamine

palladium template $\quad(R, R)$-di- $\mu$-chlorobis $\{1-[1-(N, N-$ dimethylamino)ethyl]naphthyl- $C, N\}$ dipalladium(II), $(R)-4$. The diastereomeric products were separated by column chromatography and fractional crystallization. The naphthylamine auxiliary was removed chemoselectively by treatment with concentrated hydrochloric acid. Ortho-palladation of the coordinated ligand was accomplished by stirring with silver(II) hexafluorophosphate followed by lithium chloride to form an optically active chloro-bridged dimeric complex. Alternatively, the free phosphine was coordinated to an achiral benzylamine template di- $\mu$-chlorobis $\{[(N, N-$ dimethylamino)methyl]phenyl- $C, N\}$ dipalladium(II), $\mathbf{1}$ as the palladium source for ortho-palladation. The resulting racemic chloro-bridged dimeric complexes were resolved by conversion to their $(S)$-prolinate derivatives followed by fractional crystallization. The optically active chloro-bridged dimeric complex 
was converted to its bis(acetonitrile) derivative for use as catalyst in promoting the asymmetric synthesis of P-stereogenic diarylphosphinites.

In Chapter 3, a phosphapalladacycle was prepared from a chiral phosphine ligand synthesized by catalytic asymmetric hydrophosphination reaction of a 1-naphthyl-based enone with diphenylphosphine. The template (R)-4 was used to optically purify the phosphine ligand as well as providing a palladium source for ortho-palladation to form the palladacycle. Alternatively, 1 was used as the palladium source and the palladacycles could be optically purified by conversion to their $(S)$-proline derivatives followed by fractional crystallization. The hydrophosphination reaction of the 1-naphthyl-based enone was repeated with the racemic mixture of a chiral secondary phosphine $o$ anisylphenylphosphine. The resulting $\mathrm{C}^{*}-\mathrm{P}^{*}$ phosphine ligand was coordinated to $(R)-\mathbf{4}$ for separation of stereoisomers and ortho-palladation, however the separation could not be done cleanly and ortho-palladation resulted in a racemic complex. The achiral 1 was used to coordinate to the free phosphine ligand and the diastereomeric pairs of the stereoisomers could then be separated by column chromatography. The major pair of enantionmers was ortho-palladated to form a racemic chloro-bridged dimeric complex, followed by conversion to their $(S)$ prolinate derivatives and separation by fractional crystallization to give an optically pure $\mathrm{C}^{*}-\mathrm{P}^{*}$ palladacycle with a $\mathrm{C}$ chiral centre and a $\mathrm{P}$ chiral centre.

In Chapter 4, the syntheses of isoquinoline-based palladium complexes were attempted. The asymmetric hydrophosphination reactions of an isoquinoline-based enone with secondary phosphines could be promoted with stoichiometric or catalytic amount of the bis(acetonitrile) naphthylamine complex $(R)-5$. The stoichiometric reaction stereoselectively produced a $\mathrm{P}, \mathrm{N}$ 
bidentate ligand coordinated to the metal complex. The stereoisomers were separated by column chromatography and fractional crystallization. Attempts to chemoselectively remove the naphthylamine auxiliary by treatment with concentrated hydrochloric acid resulted in a dichloro complex which racemized when left standing in solution. The catalytic reaction produced the free P,N ligand which readily racemized in solution. 


\section{CHAPTER 1: INTRODUCTION}

\subsection{Chiral Phosphines}

In the past decades, selective preparation of optically pure compounds has become the focus of organic synthesis. Asymmetric catalysis has been found to be an economical and efficient way to achieve this goal. Transition metal complexes containing chiral phosphine ligands are known to be effective catalysts in asymmetric hydrogenation reactions. ${ }^{1}$ The importance of chiral phosphine ligands in these reactions has led to the design and synthesis of a huge number of ligands. ${ }^{2}$

The optical activity of a phosphine can be derived from a P-stereogenic centre, chirality in the side chain (centre, axial or planar chirality), or less commonly a combination of a P-chiral centre and side chain chirality. The most prominent P-stereogenic chiral phosphine is DIPAMP developed by Knowles et al. in $1975,{ }^{3}$ which has found application in the asymmetric hydrogenation synthesis of L-DOPA used in treating Parkinson's Disease. ${ }^{4-5}$ An important chiral phosphine with axial chirality in the side chain is BINAP developed by Noyori in $1980,{ }^{6-7}$ which was used in the asymmetric hydrogenation of various olefins and ketones as well as other asymmetric reactions. ${ }^{8}$ For their work on chirally catalyzed hydrogenation reactions, Knowles and Noyori were awarded the Nobel Prize in Chemistry in 2001. ${ }^{9}$ Other notable chiral phosphines include DIOP,${ }^{10}$ DuPhos, ${ }^{11}$ Chiraphos, ${ }^{12}$ Josiphos, ${ }^{13}$ TangPhos, ${ }^{14}$ and DuanPhos ${ }^{15}$ (Figure 1.1). 


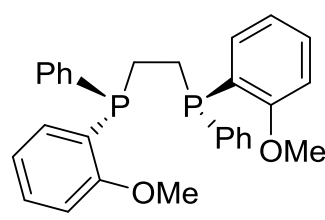

DIPAMP

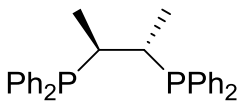

Chiraphos

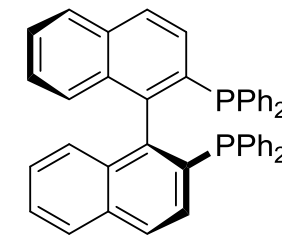

BINAP

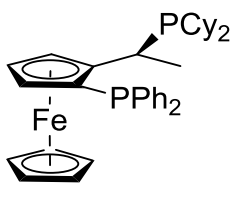

Josiphos<smiles>CC1(C)OC(CP)C(CP)O1</smiles>

DIOP

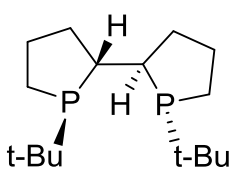

TangPhos<smiles>[R]C1CCC([R])P1c1ccccc1P1C([R])CCC1[R]</smiles>

DuPhos

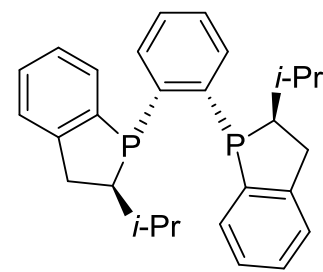

DuanPhos

Figure 1.1 Examples of chiral phosphines

\subsubsection{Methods of Preparation of Chiral Phosphines}

The importance of chiral phosphine ligands in asymmetric synthesis has led to various attempts at developing synthetic strategies to produce them efficiently. However, the lack of a natural pool of chirality, as well as the high chemical reactivity and configurational instability of the phosphorus stereocenters, ${ }^{16-17}$ makes the synthesis of this class of compounds a challenging process. There are two methods to prepare chiral phosphines: (1) chiral resolution and (2) asymmetric induction.

\section{(1) Chiral resolution}

The chiral resolution process is used to prepare an optically active compound from its racemic mixture. First, the compound is prepared in its racemic form from prochiral starting materials. A racemic mixture of a chiral compound contains equal amounts of its enantiomers. Enantiomers have identical chemical and physical properties, except for their ability to rotate plane-polarized light in equal amounts but in opposite directions, which make them difficult to separate. In the chiral resolution process, the enantiomers are 
converted into a diastereomeric mixture through coordination with an optically pure resolving agent. Examples of resolving agents used are $(R, R)$ dibenzoyltartaric acid ((-)-DBTA) and (S)-(+)-10-camphorsulfonic acid ((+)CSA). As diastereomers have different physical properties, the mixture can then be separated via column chromatography and fractional crystallization. After the separation is complete, the resolving agent is removed to give the desired optically pure product.

The synthesis of BINAP as reported by Noyori involves chiral resolution by either (+)-CSA or (-)-DBTA (Scheme 1.1$){ }^{7}$

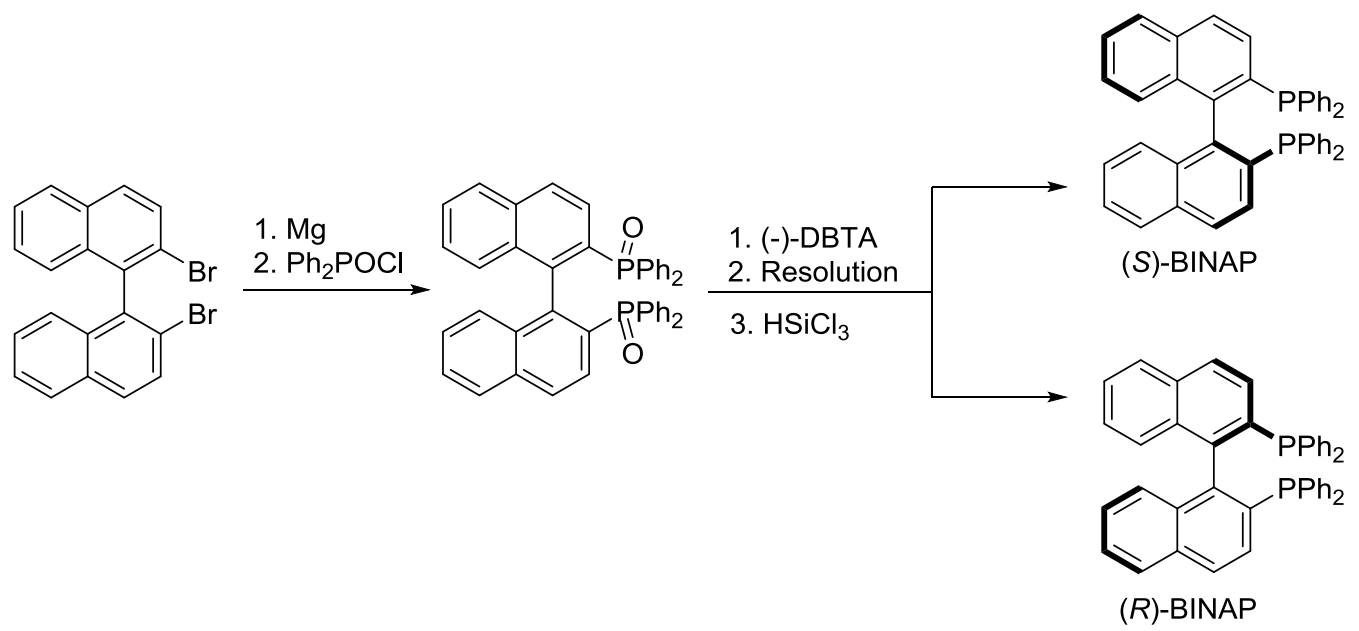

\section{Scheme 1.1}

\section{(2) Asymmetric induction}

Asymmetric induction refers to the preferential formation of one enantionmer or disastereomer in a chemical reaction by the influence of a chiral feature present in the substrate, reagent, catalyst or environment. ${ }^{18}$ There are three principle ways to introduce chirality in the product: (i) internal asymmetric induction, (ii) relayed asymmetric induction and (iii) external asymmetric induction. ${ }^{19}$ 
In internal asymmetric induction, the chiral centre of the chiral substrate is incorporated into the final product. For example, $(S, S)$-Chiraphos can be synthesized from $(2 R, 3 R)$-2,3-butanediol through reaction with tosyl chloride and lithium diphenylphosphide (Scheme 1.2). ${ }^{12}$

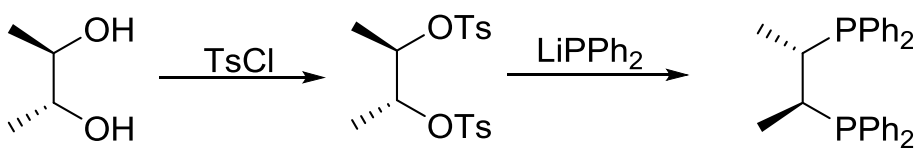

$(S, S)$-Chiraphos

\section{Scheme 1.2}

In relayed asymmetric induction, chirality is relayed through the use of a chiral auxiliary. The chiral auxiliary is introduced prior to the chirality generation step, and is removed after the new chiral centres are formed (Scheme 1.3). ${ }^{20}$

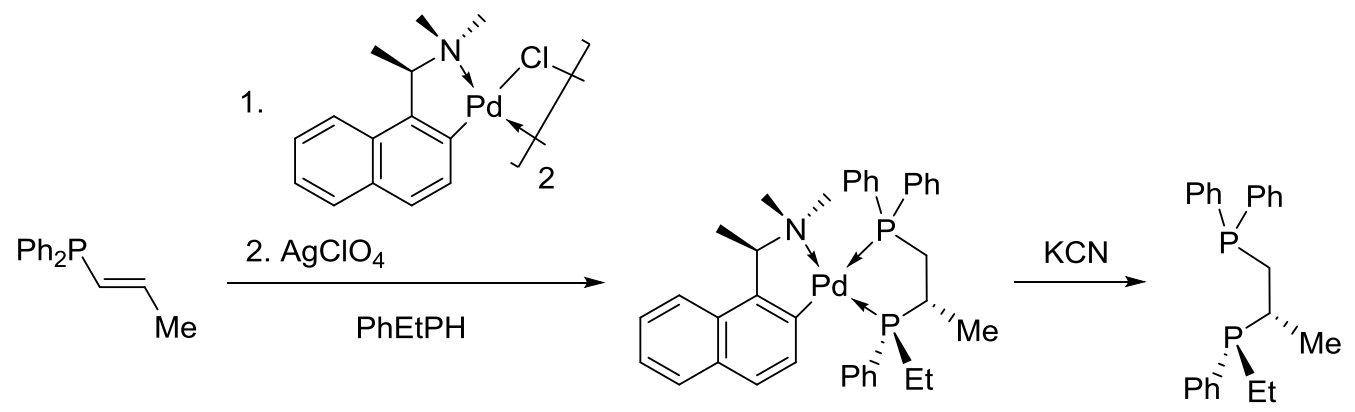

\section{Scheme 1.3}

In external asymmetric induction, a chiral catalyst is used to control the stereoselectivity of the reaction in the transition state. As the catalyst is not consumed in the asymmetric catalytic process, only a small amount is needed in the reaction to give the product with high enantioselectivity (Scheme 1.4). ${ }^{21}$ 


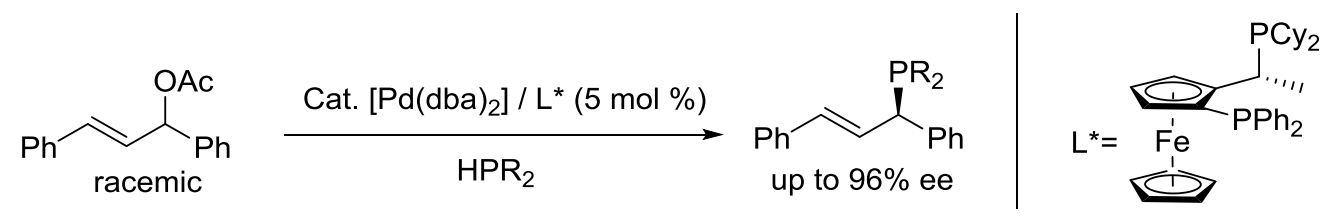

Scheme 1.4

\subsection{Palladacycles}

Palladium compounds containing at least one metal-carbon bond intramolecularly stabilized by at least one donor atom, termed cyclopalladated compounds or palladacycles, are one of the most popular classes of organopalladium derivatives. $^{22}$

Palladacycles can be divided into two types: the anionic four-electron donor or CY type; and the anionic six-electron donor or YCY type, also known as the pincer type. ${ }^{22}$<smiles>[X][P+]1([X])CCCC1</smiles>

CY type<smiles>[Y][Pb]1([X])[Y]CCC1</smiles>

YCY type

This thesis focuses on the discussion of the CY type of palladacycles.

In 1968, Cope reported the cyclopalladation of $N, N-$ dimethylbenzylamine with a palladium salt, lithium tetrachloropalladate(II), to form a benzylamine palladacycle 1 (Scheme 1.5$){ }^{23}$

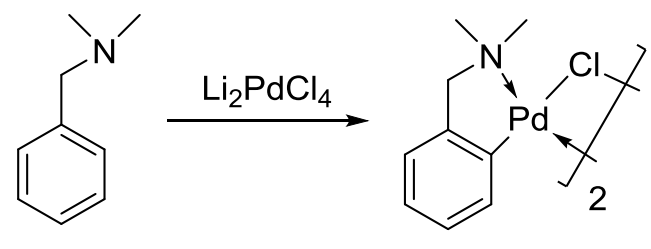

Scheme 1.5 
In 1971, Otsuka reported the formation of a chiral benzylamine palladacycle $(S)-\mathbf{2}$ by the treatment of a chiral benzylamine with sodium tetrachloropalladate(II) (Scheme 1.6). ${ }^{24}$ This chiral palladacycle (S)-2 was used in the chiral resolution of various tertiary phosphines.
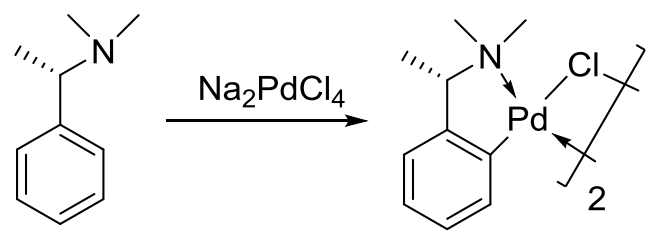

(S)-2

\section{Scheme 1.6}

In 1977, Tani reported a naphthalene-based chiral palladacycle $(S)-3$ synthesized from the reaction between a chiral naphthylamine and sodium tetrachloropalladate(II) in the presence of triethylamine (Scheme 1.7). ${ }^{25}$
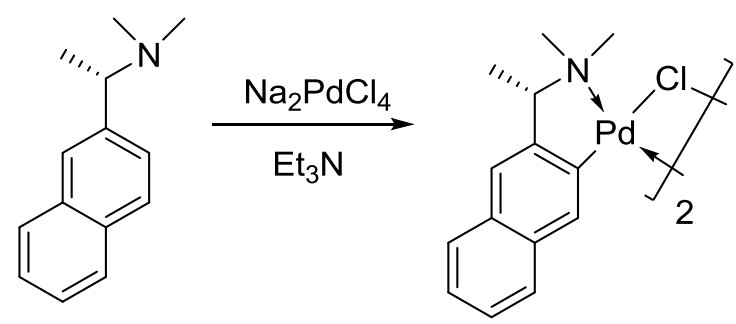

(S)-3

\section{Scheme 1.7}

In 1982, Wild and co-workers reported a chiral naphthalene-based palladacycle $(R)-\mathbf{4}$ by treating a chiral naphthylamine with lithium tetrachloropalladate(II) (Scheme 1.8). ${ }^{26}$

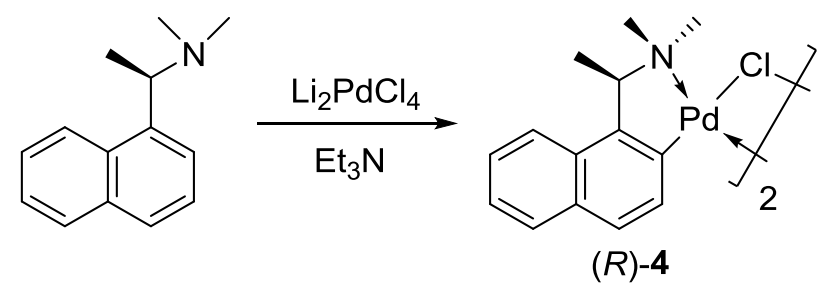

Scheme 1.8 
Complex $(R)-4$ was found to be more efficient in the chiral resolution process than the benzylamine analogue $(S)-2$. The interaction between the $\mathrm{H}(8)$ on the naphthyl ring with the methyl group on 5-membered palladacycle ring forces the methyl group to adopt the axial position, and locking the 5membered ring in the $\delta$ position. On the other hand, the 5-membered ring on the benzylamine counterpart undergoes rapid transformation between the $\delta$ and $\lambda$ conformations in solution, making it less effective in controlling stereoselectivity. $^{27}$

In 1992, Leung and co-workers reported the conversion of chlorobridged $(R)-\mathbf{4}$ into its bis(acetonitrile) derivative $(R)-\mathbf{5}$ (Scheme 1.9), providing two active sites for the coordination of phosphines and other functional groups. $^{28}$

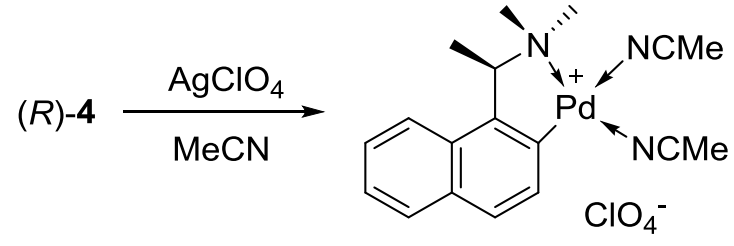

$(R)-5$

\section{Scheme 1.9}

Complex $(R)-5$ was successfully used as a stoichiometric template to control the stereoselectivity of various reactions such as Diels-Alder, hydroamination, hydrophosphination and hydroarsination reactions. ${ }^{16}$ In 2010 , the use of $(R)-5$ was extended to catalyze asymmetric hydrophosphination reactions in a catalytic amount. ${ }^{29}$

In 2003, Leung and co-workers reported the synthesis of a phosphine analogue of $(R)-\mathbf{4}$ via a multi-step approach, forming the complex $(R)-6 .{ }^{30}$ The 
phosphapalladacycle $(R)-6$ was converted to its bis(acetonitrile) complex $(R)-7$ to be used in catalytic hydrophosphination reactions (Scheme 1.10). ${ }^{31}$

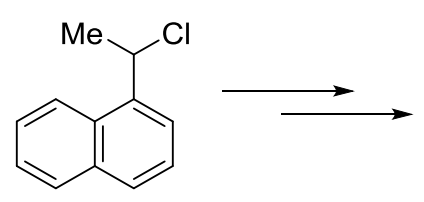

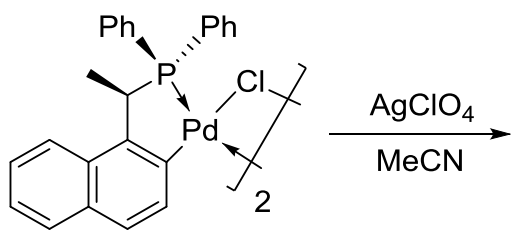

$(R)-6$<smiles>C[C@H]1c2c(ccc3ccccc23)[P+](N(C)C)(N(C)c2ccccc2)[P+]1(c1ccccc1)N(C)C</smiles>

$(R)-7$

\section{Scheme 1.10}

Comparing $(R)-\mathbf{5}$ and $(R)-\mathbf{7},(R)-\mathbf{7}$ was found to be the better performing catalyst, as it offers a higher yield, higher stereoselectivity and faster reaction time (Scheme 1.11). ${ }^{32}$

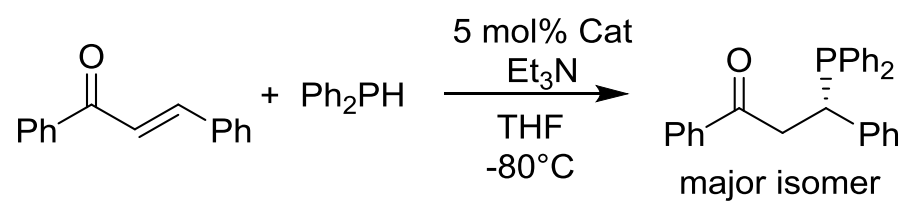

Cat:<smiles>CN[P+]1(NC)c2ccc3ccccc3c2C(C)N1C</smiles>

$(R)-5$

yield $=65 \%$, ee $=77 \%, 23 \mathrm{~h}$<smiles>CC1c2c(ccc3ccccc23)[P+](c2ccccc2)(N(C)C)P1c1ccccc1</smiles>

$(R)-7$

\section{Scheme 1.11}

The enhanced reactivity of $(R)-7$ is due to the ability of the phosphorus in the palladacycle ring to accommodate extensive back-donation from the metal centre, making the activation of the diphenylphosphine and its nucleophilic attack on the trans-chalcone substrate more facile. The faster reaction time can be attributed to the classic features that trans $\mathrm{P}-\mathrm{Pd}-\mathrm{P}$ bonds are less stable than trans N-Pd-P bonds, thus resulting in faster product elimination in the catalytic cycle. In addition, the larger phenyl groups in $(R)-7$ 
are able to project greater stereochemical influence on the reaction site, giving an increased stereoselectivity. ${ }^{33}$

The enantiomeric excess (ee) was determined by coordinating the free phosphines to $(R)-4$ to form diastereomeric complexes (Scheme 1.12), which would exhibit different ${ }^{31} \mathrm{P}\left\{{ }^{1} \mathrm{H}\right\}$ NMR chemical shifts. The ee values can then be calculated from the integral values of the NMR peaks. ${ }^{32}$

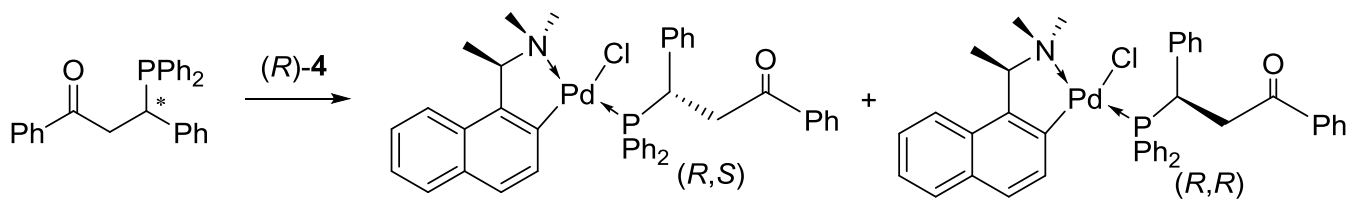

\section{Scheme 1.12}

\subsection{Objectives of Present Project}

Over the past decades, many efforts had been made in developing chiral palladacycles and their applications as efficient promoters in the synthesis of chiral phosphines and arsines by means of Diels-Alder, hydroamination, hydrophosphination, and hydroarsination reactions. This project is targeted at the development of asymmetric $\mathrm{C}-\mathrm{P}$ bond formation via hydrophosphination for the efficient synthesis of chiral tertiary phosphines, as well as the development of palladacycles as promoters or catalysts for this kind of reaction.

Palladacycles are useful in promoting asymmetric synthesis in both stoichoimetric and catalytic amounts. In particular, $(R)-\mathbf{7}$ has been demonstrated to have very good catalytic properties with up to $99 \%$ ee. However, $(R)-7$ is prepared via tedious chiral resolution of a racemic phosphine which yields at most $50 \%$ of the desired enantiomer. The aim of this project is to develop new 
phosphapalladacycles via asymmetric synthesis to simplify or eliminate the process of separating the enantionmers.

This thesis is divided into four chapters. Chapter 2 describes the synthesis of a new phosphapalladacycle via chiral resolution and its application in catalytic asymmetric synthesis. Chapter 3 deals with the preparation of a new naphthalene-based phosphapalladacycle via catalytic asymmetric synthesis of an enone, and the development of a $\mathrm{C}^{*}-\mathrm{P}^{*}$ palladacycle using the same method. Chapter 4 investigates the formation of isoquinoline-based $\mathrm{P}-\mathrm{N}$ bidentate ligands via asymmetric synthesis controlled by a palladacycle in both stoichiometric and catalytic amounts. 


\section{CHAPTER 2: CYCLOPALLADATION OF 1-[(2,5- DIISOPROPYLPHENYL)ETHYL]DIPHENYLPHOSPHINE}

\subsection{Introduction}

The naphthylamine template $(R)-\mathbf{4}$ has been shown to be effective in controlling stereoselectivity of various reactions, including Diels-Alder reactions to form diphosphines. ${ }^{34-36}$

In addition to the steric effect by $\mathrm{H}(8)$ on the naphthyl ring, the regioselectivity in the Diels-Alders reaction is also influenced by the substituent on the $\mathrm{C}(3)$ position. The synthesis of a 3,6-dimethylnaphthylamine template and its use in Diels-Alder reactions showed a repulsion between the methyl group on $\mathrm{C}(3)$ and the phosphines that affected the selectivity of the reaction. ${ }^{37}$

In this chapter, a 3,6-diisopropylbenzylphosphine template is designed to incorporate an isopropyl group in the $\mathrm{C}(3)$ position, another isopropyl group in the $\mathrm{C}(6)$ position to provide the steric effect to lock the palladacycle ring, as well as a diphenylphosphine group as phosphine-based templates have been showed to have a better stereoselectivity than amine-based templates. The new template is tested as a catalyst in hydrophosphination reaction as well as the asymmetric synthesis of P-chiral diarylphosphinites to study its effectiveness.

\subsection{Research Objectives}

The research objectives are to synthesize the phosphine analogue of the 3,6-dimethylnaphthylamine, and to attempt cyclopalladation of the phosphine to form a phosphapalladacycle. The properties of the phosphapalladacycle are then studied. 


\subsection{Results and Discussion}

\subsubsection{Synthesis of the racemic phosphine ligand 11}

The phosphine ligand was synthesized via a multistep approach. Aldehyde $\mathbf{8}$ was treated with methyl magnesium bromide to form a racemic alcohol ( \pm -9. The chlorination of $( \pm)-9$ was done by adding phosphorus trichloride, resulting in $( \pm)-\mathbf{1 0}$. The chloride underwent nucleophilic displacement by sodium diphenylphosphide to yield the racemic tertiary phosphine ( \pm )-11 (Scheme 2.1).<smiles>CCCc1ccc(C(=O)c2ccccc2)c(C(C)=O)c1</smiles>

8<smiles>CCCc1ccc(C(C)C)c(C(C)O)c1</smiles>

$( \pm)-9$<smiles>CCCc1ccc(C(C)C)c(C(C)Cl)c1</smiles>

$( \pm)-10$

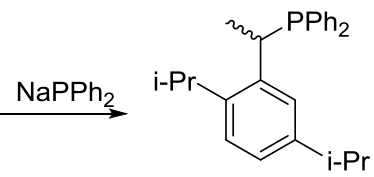

$( \pm)-11$

Scheme 2.1

\subsubsection{Optical resolution of 11 by coordination to $(R)-4$}

The free phosphines were coordinated to $(R)-\mathbf{4}$ and separated by column chromatography and fractional crystallization (Scheme 2.2).

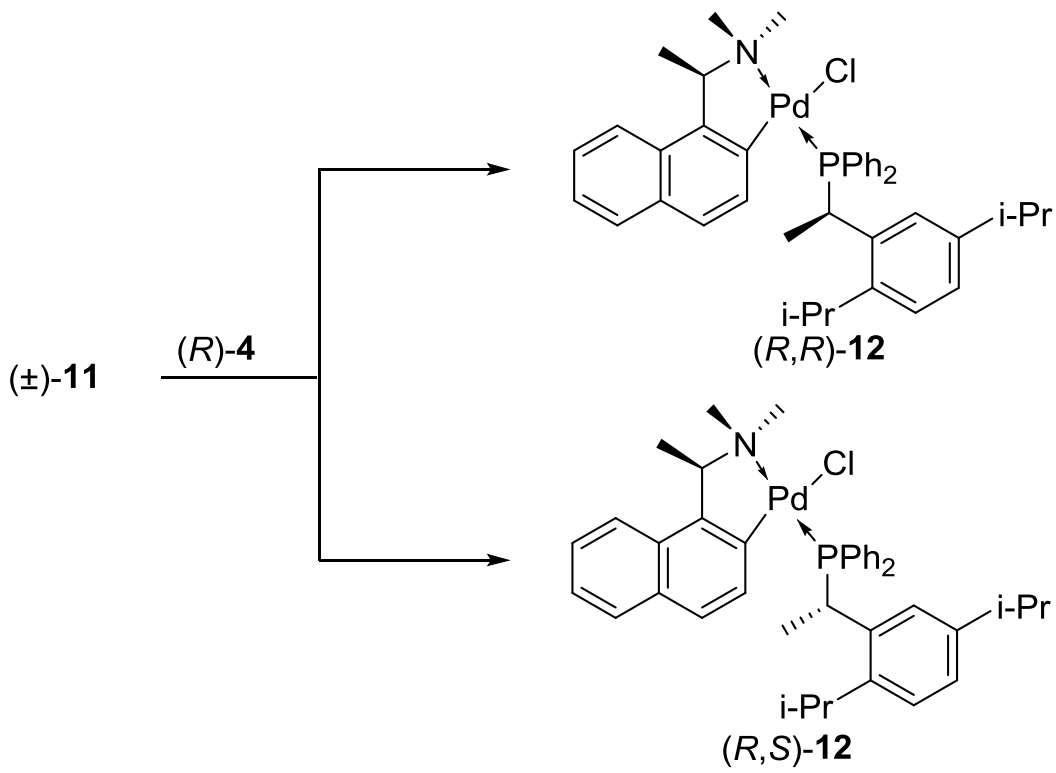

Scheme 2.2 
Both disastereomers $(R, R)-\mathbf{1 2}$ and $(R, S)-\mathbf{1 2}$ were successfully crystallized as yellow crystals. The less soluble $(R, S)-\mathbf{1 2}$ crystallized first as fine yellow needles and X-ray crystallography was performed to confirm the stereoconfiguration (Figure 2.1).

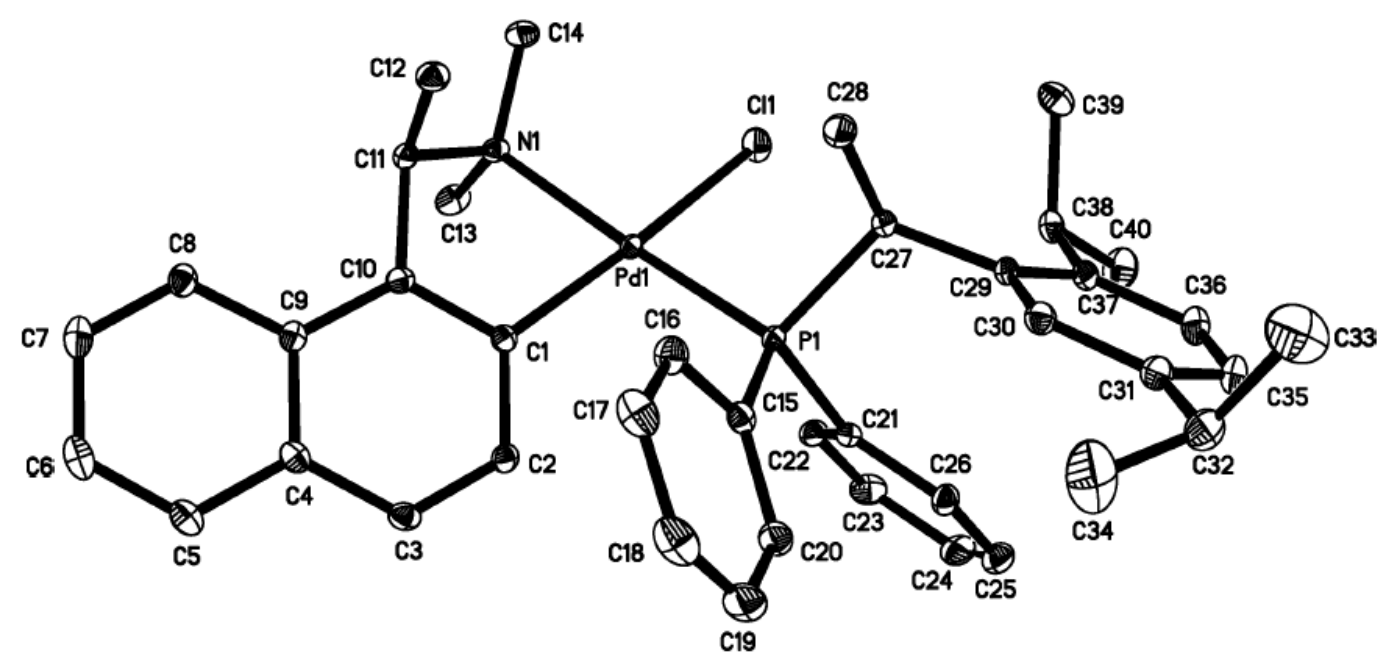

Figure 2.1 X-ray molecular structure of $(R, S)-12$

Table 2.1 Selected bond lengths $(\AA)$ and angles $\left({ }^{\circ}\right)$ of $(R, S)-12$

\begin{tabular}{llll}
\hline $\mathrm{Pd}(1)-\mathrm{C}(1)$ & $1.999(2)$ & $\mathrm{Pd}(1)-\mathrm{N}(1)$ & $2.1474(17)$ \\
$\mathrm{Pd}(1)-\mathrm{P}(1)$ & $2.2634(6)$ & $\mathrm{Pd}(1)-\mathrm{Cl}(1)$ & $2.4091(5)$ \\
$\mathrm{C}(11)-\mathrm{N}(1)$ & $1.511(3)$ & $\mathrm{C}(13)-\mathrm{N}(1)$ & $1.478(3)$ \\
$\mathrm{C}(14)-\mathrm{N}(1)$ & $1.488(3)$ & $\mathrm{C}(15)-\mathrm{P}(1)$ & $1.832(2)$ \\
$\mathrm{C}(21)-\mathrm{P}(1)$ & $1.824(2)$ & $\mathrm{C}(27)-\mathrm{P}(1)$ & $1.871(2)$ \\
$\mathrm{C}(27)-\mathrm{C}(29)$ & $1.510(3)$ & $\mathrm{C}(29)-\mathrm{C}(30)$ & $1.399(3)$ \\
& & & \\
$\mathrm{C}(1)-\mathrm{Pd}(1)-\mathrm{N}(1)$ & $81.22(8)$ & $\mathrm{C}(1)-\mathrm{Pd}(1)-\mathrm{P}(1)$ & $95.61(6)$ \\
$\mathrm{N}(1)-\mathrm{Pd}(1)-\mathrm{P}(1)$ & $169.12(5)$ & $\mathrm{C}(1)-\mathrm{Pd}(1)-\mathrm{Cl}(1)$ & $169.02(6)$ \\
$\mathrm{N}(1)-\mathrm{Pd}(1)-\mathrm{Cl}(1)$ & $91.68(5)$ & $\mathrm{P}(1)-\mathrm{Pd}(1)-\mathrm{Cl}(1)$ & $92.862(19)$ \\
$\mathrm{C}(15)-\mathrm{P}(1)-\mathrm{Pd}(1)$ & $117.65(8)$ & $\mathrm{C}(21)-\mathrm{P}(1)-\mathrm{Pd}(1)$ & $113.69(8)$ \\
$\mathrm{C}(27)-\mathrm{P}(1)-\mathrm{Pd}(1)$ & $105.87(7)$ & $\mathrm{C}(29)-\mathrm{C}(27)-\mathrm{P}(1)$ & $113.83(15)$ \\
$\mathrm{C}(30)-\mathrm{C}(29)-\mathrm{C}(27)$ & $119.82(19)$ & & \\
\hline
\end{tabular}

The X-ray crystallographic study showed that the chiral centre at $\mathrm{C}(27)$ adopts the $S$ configuration. 


\subsubsection{Removal of naphthylamine auxiliary and ortho-palladation}

The naphthylamine auxiliary was removed upon the addition of concentrated hydrochloric acid to $(R, S)-\mathbf{1 2}$ to give $(S, S)$-13 (Scheme 2.3). The reaction proceeded in very high yield of $99 \%$.

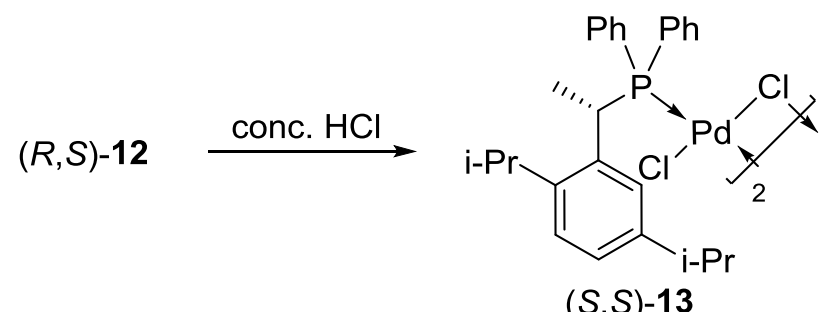

Scheme 2.3

Two methods were used to generate the ortho-palladation product. In the first method, $(S, S)$-13 was heated to reflux in ethanol in the presence of sodium acetate trihydrate. $(S, S)-\mathbf{1 4}$ was formed in the yield of $32 \%$ (Scheme 2.4).

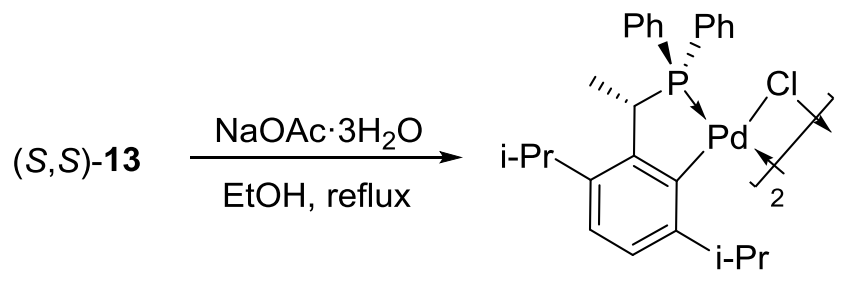

$(S, S)-14$

\section{Scheme 2.4 Method 1}

In the second method, $(S, S)-\mathbf{1 3}$ was stirred with silver(I) hexafluorophosphate, then followed by lithium chloride to form $(S, S)-\mathbf{1 4}$, giving a yield of 35\% (Scheme 2.5). 


$$
(S, S)-13 \underset{\text { 2. } \mathrm{LiCl}}{\stackrel{\text { 1. } \mathrm{AgPF}_{6}}{\longrightarrow}}(S, S)-14
$$

\section{Scheme 2.5 Method 2}

\subsubsection{Coordination to 1 and cyclopalladation of 11}

An alternative approach was explored by using achiral benzylamine template $\mathbf{1}$ as palladium source (Scheme 2.6).<smiles>CCCc1ccc(C(C)C)c([C@H](C)c2ccccc2P[P+](Cl)(c2ccccc2)N(C)C)c1</smiles>

$( \pm)-15$

\section{Scheme 2.6}

The benzylamine auxiliary was removed by concentrated hydrochloric acid and ortho-palladation was carried out by refluxing with sodium acetate trihydrate in ethanol to form the racemic dimer 14 (Scheme 2.7).

$( \pm)-15$

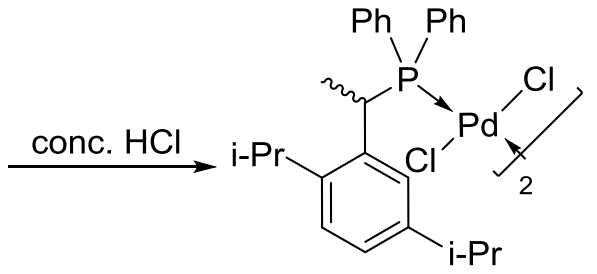

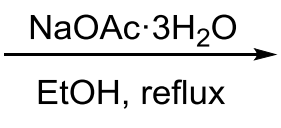

13

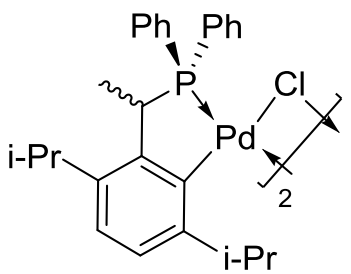

14

Scheme 2.7 
Optical resolution of the racemic dimer $\mathbf{1 4}$ was attempted by using potassium (S)-prolinate to form the diastereomers $\left(R, S_{\mathrm{N}}\right)-\mathbf{1 6}$ and $\left(S, S_{\mathrm{N}}\right)-\mathbf{1 6}$ (Scheme 2.8).

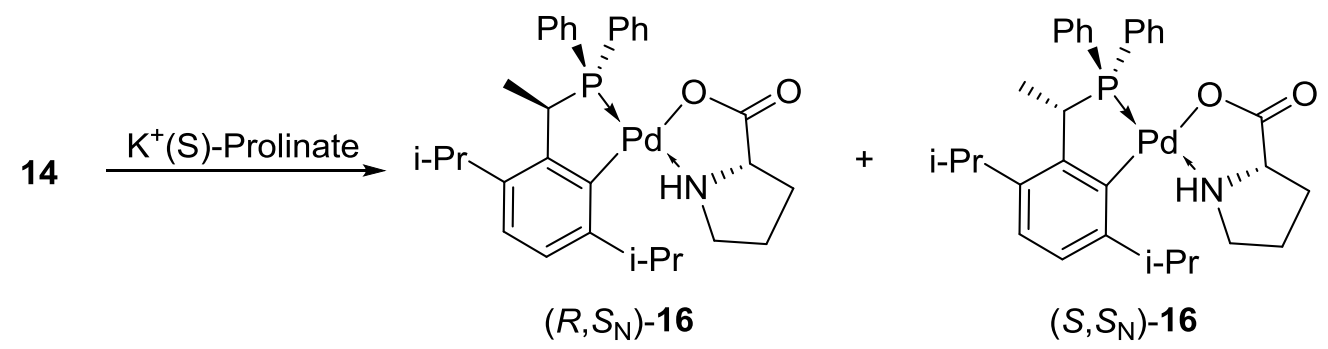

Scheme 2.8

Attempts to separate the diastereomers by crystallization using various solvents were unsuccessful.

\subsubsection{Coordination of $(S, S)$-14 with triphenylphosphine and dppe}

The properties of $(S, S)$-14 were studied by coordination to triphenylphosphine and 1,2-bis(diphenylphosphino)ethane (dppe).

Triphenylphosphine was added to $(S, S)$-14 to give a mixture of trans and cis products (Scheme 2.9), however they could not be induced to crystallized.

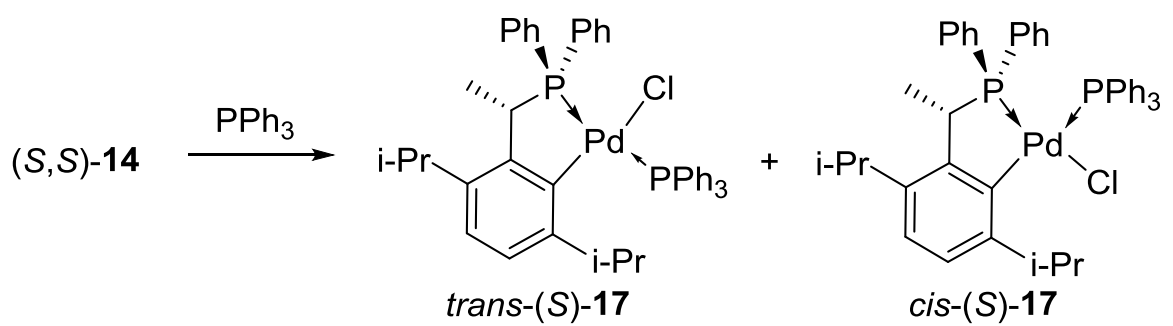

Scheme 2.9 
The bidentate ligand dppe was coordinated to $(S, S)-\mathbf{1 4}$ to form the monomer complex $(S)$-18 (Scheme 2.10).

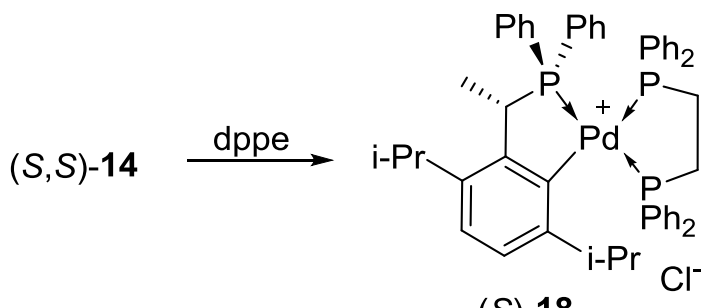

(S)-18

Scheme 2.10

Complex $(S)$-18 was successfully crystallized from dichloromethanehexane to give yellow crystals, and X-ray crystallographic study was performed (Figure 2.2).

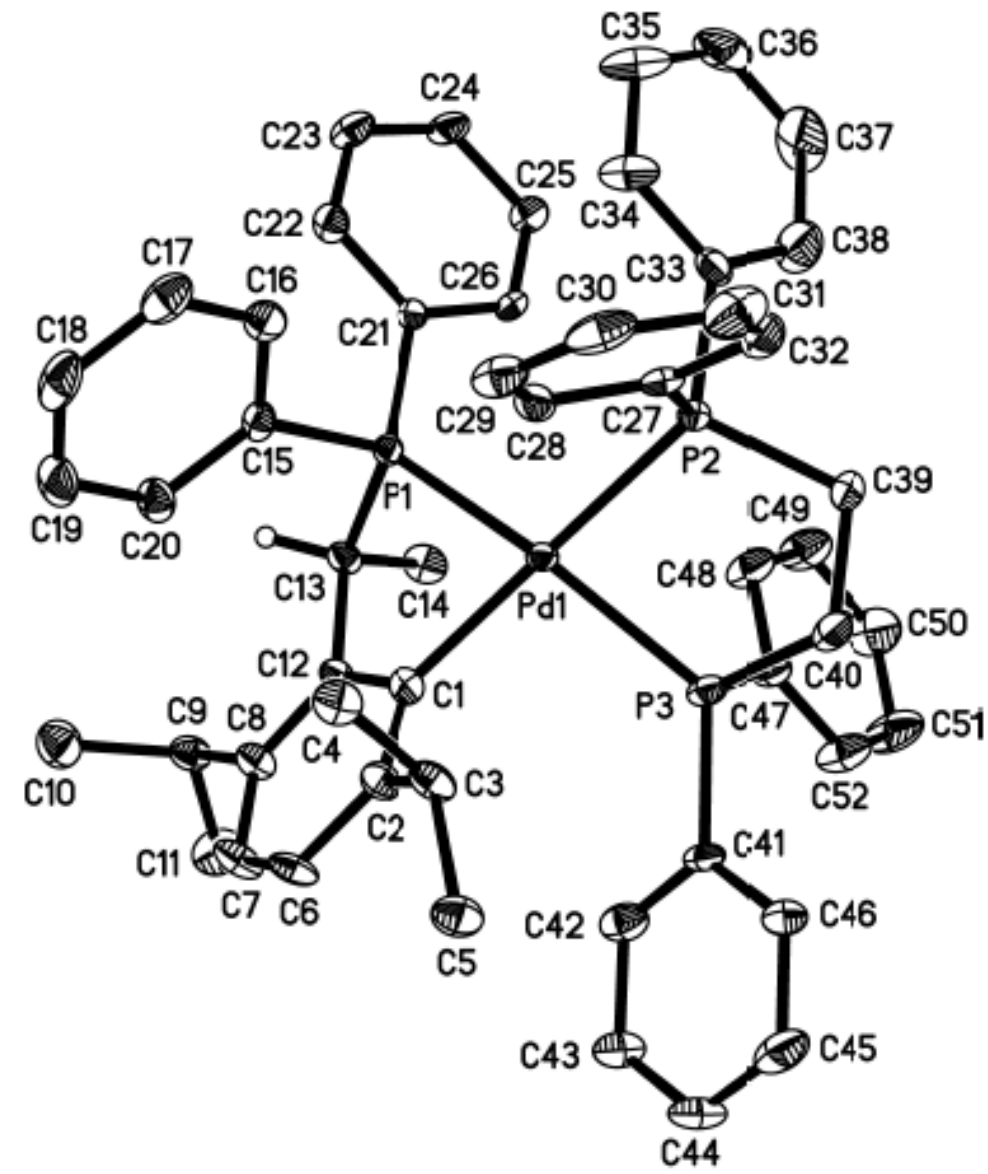

Figure 2.2 X-ray molecular structure of $(S)-18$ 
Table 2.2 Selected bond lengths $(\AA)$ and angles $\left(^{\circ}\right)$ of $(S)-18$

\begin{tabular}{llll}
\hline $\mathrm{Pd}(1)-\mathrm{C}(1)$ & $2.082(4)$ & $\mathrm{Pd}(1)-\mathrm{P}(1)$ & $2.2738(12)$ \\
$\mathrm{Pd}(1)-\mathrm{P}(3)$ & $2.3130(12)$ & $\mathrm{Pd}(1)-\mathrm{P}(2)$ & $2.3473(12)$ \\
$\mathrm{C}(1)-\mathrm{C}(12)$ & $1.406(6)$ & $\mathrm{C}(12)-\mathrm{C}(13)$ & $1.527(6)$ \\
$\mathrm{C}(13)-\mathrm{P}(1)$ & $1.856(4)$ & $\mathrm{C}(15)-\mathrm{P}(1)$ & $1.822(4)$ \\
$\mathrm{C}(21)-\mathrm{P}(1)$ & $1.803(5)$ & $\mathrm{C}(39)-\mathrm{C}(40)$ & $1.531(6)$ \\
$\mathrm{C}(39)-\mathrm{P}(2)$ & $1.839(4)$ & $\mathrm{C}(40)-\mathrm{P}(3)$ & $1.828(5)$ \\
& & & \\
$\mathrm{C}(1)-\mathrm{Pd}(1)-\mathrm{P}(1)$ & $76.24(13)$ & $\mathrm{C}(1)-\mathrm{Pd}(1)-\mathrm{P}(3)$ & $97.32(13)$ \\
$\mathrm{P}(1)-\mathrm{Pd}(1)-\mathrm{P}(3)$ & $156.70(4)$ & $\mathrm{C}(1)-\mathrm{Pd}(1)-\mathrm{P}(2)$ & $168.31(13)$ \\
$\mathrm{P}(1)-\mathrm{Pd}(1)-\mathrm{P}(2)$ & $108.15(4)$ & $\mathrm{P}(3)-\mathrm{Pd}(1)-\mathrm{P}(2)$ & $82.68(4)$ \\
$\mathrm{C}(12)-\mathrm{C}(1)-\mathrm{Pd}(1)$ & $119.4(3)$ & $\mathrm{C}(1)-\mathrm{C}(12)-\mathrm{C}(13)$ & $116.1(4)$ \\
$\mathrm{C}(12)-\mathrm{C}(13)-\mathrm{P}(1)$ & $102.7(3)$ & $\mathrm{C}(13)-\mathrm{P}(1)-\mathrm{Pd}(1)$ & $98.96(15)$ \\
$\mathrm{C}(40)-\mathrm{C}(39)-\mathrm{P}(2)$ & $109.3(3)$ & $\mathrm{C}(39)-\mathrm{C}(40)-\mathrm{P}(3)$ & $108.2(3)$ \\
$\mathrm{C}(39)-\mathrm{P}(2)-\mathrm{Pd}(1)$ & $109.52(15)$ & $\mathrm{C}(40)-\mathrm{P}(3)-\mathrm{Pd}(1)$ & $108.30(15)$ \\
\hline
\end{tabular}

X-ray structure analysis of $(S)-\mathbf{1 8}$ showed that the stereogenic centre at C(13) adopts the $S$ absolute configuration. The crystal structure obtained confirmed the formation of the cyclopalladated 5-membered ring structure. The geometry at the Pd centre is distorted square planar with angles of 76.24(13)$108.15(4)^{\circ}$ and $156.70(4)-168.31(13)^{\circ}$. The $\mathrm{C}(14)$ methyl group is in the axial position, suggesting that steric repulsion with the isopropyl group on $\mathrm{C}(8)$ took place as expected.

\subsubsection{Use of bis(acetonitrile) complex of $(S, S)$-14 in promoting asymmetric reactions}

The dichloro-bridge complex $(S, S)-\mathbf{1 4}$ can be converted to a bis(acetonitrile) complex (S)-19 by treatment with a silver(I) salt in the presence of acetonitrile (Scheme 2.11). 


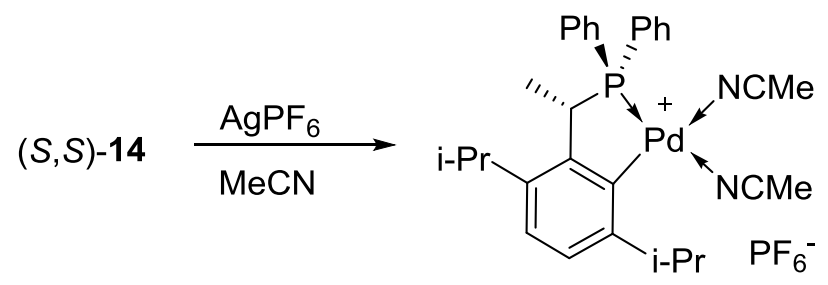

$(S)-19$

\section{Scheme 2.11}

\subsubsection{Asymmetric hydrophosphination reaction of trans-chalcone}

The hydrophosphination reaction of trans-chalcone with diphenylphosphine was attempted using $(S)$-19 as the catalyst for comparison with $(R)-5$ and $(R)-7$ (Scheme 2.12).

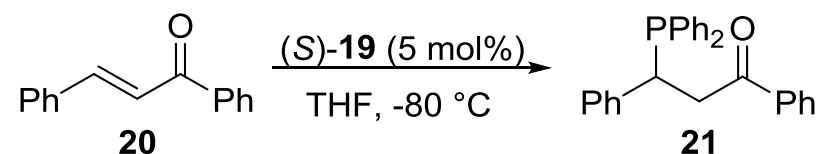

\section{Scheme 2.12}

The reaction was found to be completed within 20 hours, indicated by formation of a new peak at $\delta-1.7$ and the absence of the free diphenylphosphine peak in the ${ }^{31} \mathrm{P}\left\{{ }^{1} \mathrm{H}\right\}$ NMR spectrum. The calculated yield from the spectrum is $95 \%$. The complex $(R)-4$ was added to the free phosphine 21 to determine the ee of the reaction. The ${ }^{31} \mathrm{P}\left\{{ }^{1} \mathrm{H}\right\}$ NMR spectrum $(202 \mathrm{MHz}$, $\left.\mathrm{CDCl}_{3}\right)$ showed two product peaks at $\delta 44.9$ and 49.0 in the ratio of $1: 1.34$, giving an ee of $14.5 \%$. This is very low compared to the $77 \%$ ee achieved by $(R)-5^{29}$ and the $98 \%$ ee achieved by $(R)-7 .^{32}$

\subsubsection{Asymmetric synthesis of P-chiral diarylphosphinites}

Bis(acetonitrile) complex (S)-19 was also used in the asymmetric synthesis between racemic secondary phosphines and 2,5- 
diphenylbenzoquinone for P-O bond formation. The resulting P-chiral diarylphosphinites can be functionalized by undergoing $S_{N} 2$ reaction to generate various P-chiral phosphines derivatives.

\subsubsection{1 (9-Phenanthryl)phenylphosphine with 2,5-diphenylbenzoquinone}
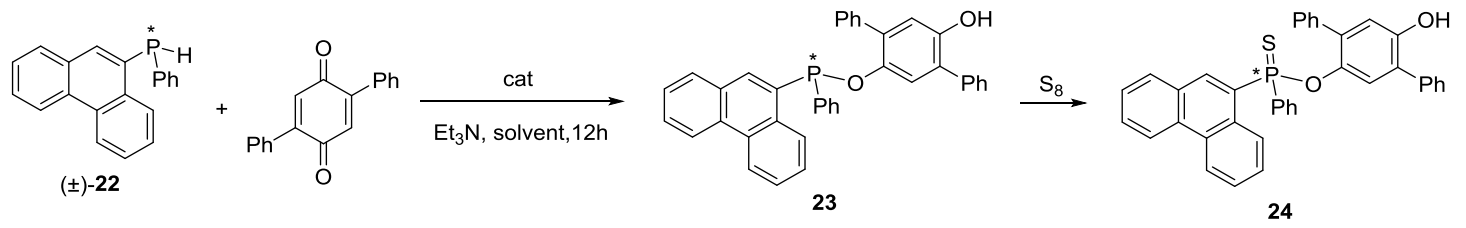

Scheme 2.13

Table 2.3 Screening of reaction conditions for the formation of 24

\begin{tabular}{ccccc}
\hline Entry & Catalyst & Solvent & Temp $\left({ }^{\circ} \mathrm{C}\right)$ & ee $(\%)^{\mathrm{a}}$ \\
\hline $1^{\mathrm{b}}$ & $\mathrm{Pd}(\mathrm{OAc})_{2}$ & $\mathrm{CHCl}_{3}$ & r.t. & - \\
2 & $(S)-\mathbf{7}$ & $\mathrm{CHCl}_{3}$ & -45 & 25 \\
3 & $(S)-\mathbf{7}$ & $\mathrm{DCM}$ & -45 & 25 \\
4 & $(S)-\mathbf{7}$ & $\mathrm{DCM}$ & -80 & 27 \\
5 & $(S)-\mathbf{7}$ & $\mathrm{THF}$ & -80 & -5 \\
6 & $(R)-\mathbf{7}$ & $\mathrm{CHCl}_{3}$ & -45 & -25 \\
7 & $(S)-\mathbf{1 9}$ & $\mathrm{CHCl}_{3}$ & -45 & 2 \\
8 & $(S)-\mathbf{1 9}$ & $\mathrm{CHCl}_{3}$ & -60 & -22 \\
\hline
\end{tabular}

${ }^{\mathrm{a}}$ Determined by chiral HPLC analysis of 24. IC column was used with eluant hexane:IPA = 98:2.

${ }^{\mathrm{b}}$ Reaction to produce racemic product for comparison purposes. Reaction completed in 2 hours at r.t.

The reaction between (9-phenanthryl)phenylphosphine with 2,5diphenylbenzoquinone proceeded smoothly. $(S)$-19 in entry 8 , while requiring a lower temperature, produce similar selectivity with $(R) /(\mathrm{S})-7$.

The phosphinite sulfide $\mathbf{2 4}$ was crystallized as a racemic crystal and Xray crystallography was performed (Figure 2.3). 


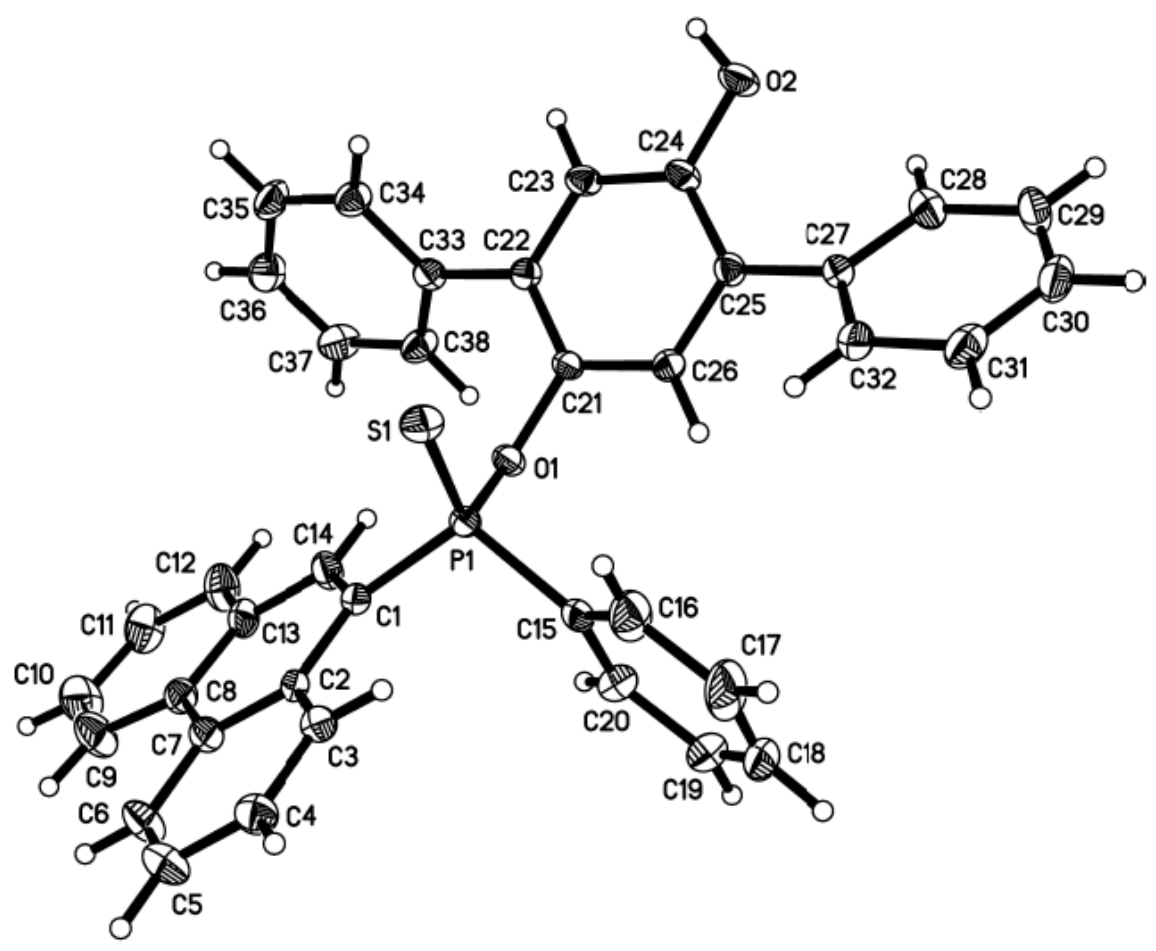

Figure 2.3 X-ray molecular structure of rac-24

Table 2.4 Selected bond lengths $(\AA)$ and angles $\left(^{\circ}\right)$ of rac-24

\begin{tabular}{llll}
\hline $\mathrm{C}(1)-\mathrm{P}(1)$ & $1.8117(18)$ & $\mathrm{C}(15)-\mathrm{P}(1)$ & $1.8103(19)$ \\
$\mathrm{O}(1)-\mathrm{P}(1)$ & $1.6198(14)$ & $\mathrm{P}(1)-\mathrm{S}(1)$ & $1.9399(7)$ \\
$\mathrm{C}(21)-\mathrm{O}(1)$ & $1.408(2)$ & $\mathrm{C}(21)-\mathrm{C}(22)$ & $1.396(2)$ \\
$\mathrm{C}(22)-\mathrm{C}(23)$ & $1.392(3)$ & $\mathrm{C}(23)-\mathrm{C}(24)$ & $1.397(2)$ \\
$\mathrm{C}(24)-\mathrm{C}(25)$ & $1.400(3)$ & $\mathrm{C}(25)-\mathrm{C}(26)$ & $1.399(2)$ \\
$\mathrm{C}(21)-\mathrm{C}(26)$ & $1.386(2)$ & $\mathrm{C}(24)-\mathrm{O}(2)$ & $1.365(2)$ \\
$\mathrm{C}(22)-\mathrm{C}(33)$ & $1.488(2)$ & $\mathrm{C}(25)-\mathrm{C}(27)$ & $1.486(2)$ \\
& & & \\
$\mathrm{O}(1)-\mathrm{P}(1)-\mathrm{C}(15)$ & $104.29(8)$ & $\mathrm{O}(1)-\mathrm{P}(1)-\mathrm{C}(1)$ & $99.50(8)$ \\
$\mathrm{C}(15)-\mathrm{P}(1)-\mathrm{C}(1)$ & $109.24(9)$ & $\mathrm{O}(1)-\mathrm{P}(1)-\mathrm{S}(1)$ & $115.58(5)$ \\
$\mathrm{C}(15)-\mathrm{P}(1)-\mathrm{S}(1)$ & $111.37(7)$ & $\mathrm{C}(1)-\mathrm{P}(1)-\mathrm{S}(1)$ & $115.71(6)$ \\
$\mathrm{C}(21)-\mathrm{O}(1)-\mathrm{P}(1)$ & $119.94(11)$ & $\mathrm{C}(26)-\mathrm{C}(21)-\mathrm{C}(22)$ & $121.69(16)$ \\
$\mathrm{C}(26)-\mathrm{C}(21)-\mathrm{O}(1)$ & $119.06(15)$ & $\mathrm{C}(22)-\mathrm{C}(21)-\mathrm{O}(1)$ & $119.25(15)$ \\
$\mathrm{O}(2)-\mathrm{C}(24)-\mathrm{C}(23)$ & $121.29(16)$ & $\mathrm{O}(2)-\mathrm{C}(24)-\mathrm{C}(25)$ & $118.28(16)$ \\
$\mathrm{C}(23)-\mathrm{C}(24)-\mathrm{C}(25)$ & $120.43(17)$ & & \\
\hline
\end{tabular}


While the absolute stereoconfiguration was indeterminate, the crystal structure obtained confirmed the formation of the product with the presence of the P-O bond.

\subsubsection{2 (1-Naphthyl)phenylphosphine with 2,5-diphenylbenzoquinone}

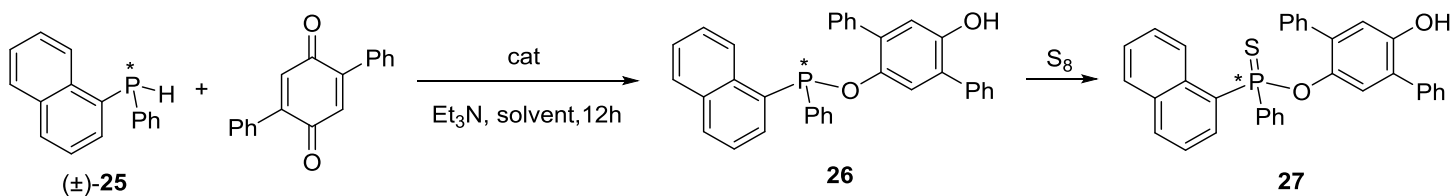

Scheme 2.14

Table 2.5 Screening of reaction conditions for the formation of 27

\begin{tabular}{ccccc}
\hline Entry & Catalyst & Solvent & Temp $\left({ }^{\circ} \mathrm{C}\right)$ & ee $(\%)^{\mathrm{a}}$ \\
\hline $1^{\mathrm{b}}$ & $\mathrm{Pd}(\mathrm{OAc})_{2}$ & $\mathrm{CHCl}_{3}$ & r.t. & - \\
2 & $(R)-\mathbf{7}$ & $\mathrm{CHCl}_{3}$ & -45 & $24^{\mathrm{c}}$ \\
3 & $(S)-\mathbf{7}$ & $\mathrm{CHCl}_{3}$ & -45 & -13 \\
4 & $(S)-\mathbf{1 9}$ & $\mathrm{CHCl}_{3}$ & -45 & 25 \\
5 & $(S)-\mathbf{1 9}$ & $\mathrm{CHCl}_{3}$ & -60 & 27 \\
6 & $(S)-\mathbf{1 9}$ & $\mathrm{CHCl}_{3}$ & -80 & 31 \\
7 & $(S)-\mathbf{1 9}$ & $\mathrm{THF}$ & -45 & 51 \\
\hline
\end{tabular}

${ }^{\mathrm{a}}$ Determined by chiral HPLC analysis of 27 . AD-H column was used with eluant hexane:IPA $=$ 95:5.

${ }^{\mathrm{b}}$ Reaction to produce racemic product for comparison purposes. Reaction completed in 2 hours at r.t.

${ }^{\mathrm{c}}$ Literature value ${ }^{38}$

The reaction between (1-naphthyl)phenylphosphine with 2,5diphenylbenzoquinone proceeded smoothly. The performance of $(S)-\mathbf{1 9}$ in entries 6 and 7 exceeds those of $(R) /(\mathrm{S})-7$.

\subsection{Conclusion}

1-[(2,5-Diisopropylphenyl)ethyl]diphenylphosphine was successfully synthesized as a racemate and optical resolution was done by using $(R)-\mathbf{4}$ as the 
resolving agent. After the naphtylamine auxiliary was removed, orthopalladation proceeded successfully to form the optically pure chloro-bridged dimer $(S, S)$-14 with a cyclopalladated 5-membered ring. The structure of the cyclopalladated ring and the absolute configuration at the $\mathrm{C}$ chiral centre were confirmed by the X-ray crystal structure analysis of the dppe derivative $(S)$-18.

The phosphapalladacycles $(S, S)-\mathbf{1 4}$ was converted to its bis(acetonitrile) derivative $(S)-\mathbf{1 9}$ to be used a catalyst in the asymmetric synthesis of P-chiral diarylphosphinites. The stereoselectivity of the new catalyst was found to be comparable to the catalyst $(S)-7$. The results could be further improved through the optimization of reaction conditions. The use of $(S)-\mathbf{1 9}$ as a catalyst in other reactions such as Diel-Alders reactions remains to be investigated.

\subsection{Experimental}

Reactions involving air-sensitive materials were performed under a positive pressure of nitrogen. NMR spectra were recorded on Bruker Avance 300, 400 and 500 spectrometers. ${ }^{1} \mathrm{H}$ and ${ }^{31} \mathrm{P}\left\{{ }^{1} \mathrm{H}\right\}$ NMR chemical shifts were referenced relative to $\mathrm{SiMe}_{4}$ and $\mathrm{H}_{3} \mathrm{PO}_{4}$ respectively. Melting points were determined on SRS-Optimelt MPA-100 apparatus and were uncorrected. Optical rotations were measured on the specified solution in a $0.1 \mathrm{dm}$ cell at $25^{\circ} \mathrm{C}$ with Atago AP-300 Automatic Polarimeter. Elemental Analyses and single crystal X-ray diffraction studies were performed by the Elemental Analysis Laboratory and X-ray Diffraction Laboratory, respectively, of the Division of Chemistry and Biological Chemistry at Nanyang Technological University. The starting materials, diphenylphosphine, ${ }^{39}$ racemic $1-(2,5-$ diisopropylphenyl)ethanol, ${ }^{40}$

9 , di- $\mu$-chlorobis $\{[(N, N$ - 
dimethylamino)methyl]phenyl- $C, N\}$ dipalladium(II) ${ }^{23} \quad \mathbf{1}, \quad(R, R)$-di- $\mu$ chlorobis $\left\{1-\left[1-(N, N\right.\right.$-dimethylamino)ethyl]naphthyl- $C, N\}$ dipalladium(II) ${ }^{26}(R)$ 4, racemic (1-naphthyl)phenylphosphine, ${ }^{38,41} \mathbf{2 5}$, and bis(acetonitrile) $\{(R)-1$ [1-(diphenylphosphino)ethyl]naphthyl- $C, P$ \} palladium(II) perchlorate, $^{31}(R)-7$, were prepared according to literature procedures.

Racemic 1-chloro-1-(2,5-diisopropylphenyl)ethane, ( 1$)-10 . \quad$ A dichloromethane solution $(380 \mathrm{~mL})$ of racemic $1-(2,5-$ diisopropylphenyl)ethanol, 9 (1.03 g, $5 \mathrm{mmol})$ was added very slowly dropwise to excess $\mathrm{PCl}_{3}(5 \mathrm{~mL})$ dissolved in the same solvent $(250 \mathrm{~mL})$ with vigorous stirring. The mixture was allowed to stir at r.t. for another $16 \mathrm{~h}$. Water was then added to the mixture dropwise (to hydrolyse the excess $\mathrm{PCl}_{3}$ ) with stirring. The organic phase was separated, further washed with water $(3 \times 100 \mathrm{~mL})$, dried with anhydrous $\mathrm{MgSO}_{4}$ and filtered. The dichloromethane was removed and the product was finally obtained as a colourless liquid upon distillation under reduced pressure, bp $62-64{ }^{\circ} \mathrm{C}, 0.3 \mathrm{mbar}, 0.99 \mathrm{~g}(88 \%) .{ }^{1} \mathrm{H}$ NMR (400 MHz, $\left.\mathrm{CDCl}_{3}\right) \delta 1.24-1.32\left(\mathrm{~m}, 12 \mathrm{H}, \mathrm{CH}\left(\mathrm{CH}_{3}\right)_{2}\right), 2.09\left(\mathrm{~d},{ }^{3} \mathrm{~J}_{\mathrm{H}-\mathrm{H}}=6.8 \mathrm{~Hz}, 3 \mathrm{H}\right.$, $\left.\mathrm{CH}\left(\mathrm{CH}_{3}\right) \mathrm{Cl}\right), 2.91\left(\mathrm{sep},{ }^{3} \mathrm{~J}_{\mathrm{H}-\mathrm{H}}=6.9 \mathrm{MHz}, 1 \mathrm{H}, \mathrm{CH}\left(\mathrm{CH}_{3}\right)_{2}\right), 3.30\left(\mathrm{sep},{ }^{3} \mathrm{~J}_{\mathrm{H}-\mathrm{H}}=6.8\right.$ $\left.\mathrm{MHz}, 1 \mathrm{H}, \mathrm{CH}\left(\mathrm{CH}_{3}\right)_{2}\right), 5.59\left(\mathrm{q},{ }^{3} \mathrm{~J}_{\mathrm{H}-\mathrm{H}}=6.9 \mathrm{MHz}, 1 \mathrm{H}, \mathrm{CH}\left(\mathrm{CH}_{3}\right) \mathrm{Cl}\right), 7.15(\mathrm{dd}$, $\left.{ }^{3} \mathrm{~J}_{\mathrm{H}, \mathrm{H}}=8.0 \mathrm{~Hz},{ }^{4} \mathrm{~J}_{\mathrm{H}, \mathrm{H}}=1.6 \mathrm{~Hz}, 1 \mathrm{H}, \operatorname{Ar}-\mathrm{C}_{5} H\right), 7.20\left(\mathrm{~d},{ }^{3} \mathrm{~J}_{\mathrm{H}, \mathrm{H}}=8.0 \mathrm{~Hz}, 1 \mathrm{H}\right.$, Ar$\left.\mathrm{C}_{6} H\right), 7.42\left(\mathrm{~d},{ }^{4} \mathrm{~J}_{\mathrm{H}, \mathrm{H}}=1.2 \mathrm{~Hz}, 1 \mathrm{H}, \operatorname{Ar}-\mathrm{C}_{3} H\right)$.

Racemic 1-(2,5-diisopropylphenyl)ethyldiphenylphosphine ( \pm )-11. A dried THF solution $(20 \mathrm{~mL})$ of sodium diphenylphosphide, freshly prepared from sodium $(0.15 \mathrm{~g})$ and diphenylphosphine $(0.75 \mathrm{~g}, 4.05 \mathrm{mmol})$, was added 
dropwise to a solution of racemic 1-chloro-1-(2,5-diisopropylphenyl)ethane, $\mathbf{1 0}$ $(0.91 \mathrm{~g}, 4.05 \mathrm{mmol})$ in dried THF $(20 \mathrm{~mL})$ with rapid stirring at r.t. White suspension obtained was evaporated until most of the THF has been removed. Fresh degassed water $(40 \mathrm{~mL})$ was added with stirring and the mixture was extracted with dichloromethane $(3 \times 40 \mathrm{~mL})$. The combined organic extracts were dried by anhydrous $\mathrm{MgSO}_{4}$, filtered and evaporated to give a colourless and air-sensitive liquid. The product was not isolated and directly used in further reactions.

Optical resolution of $( \pm)-11$. Isolation of chloro\{(R)-1-[1- $(N, N-$ dimethylamino)ethyl]naphthyl- $C, N\}[(R)-1-(2,5)-$

diisopropylphenyl)ethyldiphenylphosphine]palladium(II), $(R, R)-12$ and chloro $\{(R)-1-[1-(N, N$-dimethylamino $)$ ethyl]naphthyl- $C, N\}[(S)-1-(2,5-$

diisopropylphenyl)ethyldiphenylphosphine]palladium(II), $(\boldsymbol{R}, S)-12$. The racemic phosphine 11 was added with chiral template $(R)-\mathbf{4}(1.38 \mathrm{~g}, 2.03 \mathrm{mmol})$ in dichloromethane $(5 \mathrm{~mL})$. The resulting yellow solution was stirred for 30 min. The solvent was removed under reduced pressure to give a yellow solid; ${ }^{31} \mathrm{P}\left\{{ }^{1} \mathrm{H}\right\}$ NMR $\left(202 \mathrm{MHz}, \mathrm{CDCl}_{3}\right) \quad \delta 45.8$ (s) and $\delta 49.6$ (s) in 1:1 ratio. The combined product was separated and purified by silica gel column chromatography using hexanes/dichloromethane/acetone $(5: 1: 0.5, \mathrm{v} / \mathrm{v})$ as eluant.

\section{Chloro\{ $\{(R)-1-[1-(N, N-$ dimethylamino $)$ ethyl $]$ naphthyl- $C, N\}[(S)-1-(2,5-$}

diisopropylphenyl)ethyldiphenylphosphine]palladium(II), $(\boldsymbol{R}, S)-12$. The product was recrystallized from dichloromethane-diethyl ether to give yellow crystals $(1.26 \mathrm{~g}, 87 \%) . \mathrm{mp} 224-227{ }^{\circ} \mathrm{C} ;{ }^{31} \mathrm{P}\left\{{ }^{1} \mathrm{H}\right\}$ NMR $\left(202 \mathrm{MHz}, \mathrm{CDCl}_{3}\right) \delta$ $49.6(\mathrm{~s})$. 


\section{Chloro $\{(R)-1-[1-(N, N$-dimethylamino $)$ ethyl]naphthyl- $C, N\}[(R)-1-(2,5-$}

diisopropylphenyl)ethyldiphenylphosphine]palladium(II), (R,R)-12. The product was recrystallized from dichloromethane-diethyl ether to give yellow crystals $(1.23 \mathrm{~g}, 85 \%)$ mp 192-194 ${ }^{\circ} \mathrm{C} ;{ }^{31} \mathrm{P}\left\{{ }^{1} \mathrm{H}\right\}$ NMR $\left(202 \mathrm{MHz}, \mathrm{CDCl}_{3}\right) \delta$ $45.8(\mathrm{~s})$.

\section{$(S, S)$-Dichlorodi- $\mu$-chlorobis[1-(2,5-}

diisopropylphenyl)ethyldiphenylphosphine]dipalladium(II), (S,S)-13. Conc. $\mathrm{HCl}(1 \mathrm{~mL})$ was added to a solution of $(R, S)-12(0.40 \mathrm{~g}, 0.56 \mathrm{mmol})$ in dichloromethane $(5 \mathrm{~mL})$. The yellow solution turned orange upon adding the conc. $\mathrm{HCl}$. The solution was stirred for an hour, and then quenched by water (50 mL). The organic phase was separated, further washed with water $(2 \times 50$ $\mathrm{mL}$ ), dried with anhydrous $\mathrm{MgSO}_{4}$ and filtered. The solvent was removed under reduced pressure to give an orange solid $(0.31 \mathrm{~g}, 99 \%)$. mp $169-172{ }^{\circ} \mathrm{C} ;{ }^{31} \mathrm{P}\left\{{ }^{1} \mathrm{H}\right\}$ NMR (202 MHz, $\left.\mathrm{CDCl}_{3}\right) \delta 43.1(\mathrm{~s})$.

$(S, S)$-di- $\mu$-chlorobis $\{1$-[1-(diphenylphosphino)ethyl]-3,6-diisopropylphenylC,P palladium(II), $(S, S)-14$. Method 1: $(S, S)-13(0.19 \mathrm{~g}, 0.17 \mathrm{mmol})$ was suspended in ethanol $(25 \mathrm{~mL})$ with sodium acetate trihydrate $(0.7 \mathrm{~g})$. The mixture was heated at reflux for $2 \mathrm{~h}$, the solvent was then removed under reduced pressure. The crude product was redissolved in DCM, washed with water $\left(50 \mathrm{~mL}\right.$ x 2) and dried with anhydrous $\mathrm{MgSO}_{4}$. The product was purified by silica gel column chromatography to give a yellow solid (0.056 g, 32\%). Method 2: $(S, S)-13(0.17 \mathrm{~g}, 0.16 \mathrm{mmol})$ was dissolved in dichloromethane (5 $\mathrm{mL}) . \operatorname{AgPF}_{6}(0.16 \mathrm{~g}, 0.63 \mathrm{mmol}, 4$ equiv. $)$ in water $(1 \mathrm{~mL})$ was added to the solution in darkness, and the solution was stirred for $2 \mathrm{~h}$. The product mixture was washed with water $(50 \mathrm{~mL}$ x 2$)$ and dried with anhydrous $\mathrm{MgSO}_{4}$. The 
organic extract was combined and the solvent was removed under reduced pressure. The product was redissolved in methanol $(5 \mathrm{~mL})$ and excess $\mathrm{LiCl}(0.3$ g) was added. The solution was stirred overnight. The solvent was removed under reduced pressure. The product was redissolved in dichloromethane (5 $\mathrm{mL}$ ), washed with water (50 mL x 2) and dried with anhydrous $\mathrm{MgSO}_{4}$. The product was purified by silica gel column chromatography to give a yellow solid (0.056g, 35\%). ${ }^{31} \mathrm{P}\left\{{ }^{1} \mathrm{H}\right\} \mathrm{NMR}\left(202 \mathrm{MHz}, \mathrm{CDCl}_{3}\right) \delta 57.3$ (s).

\section{Racemic} chloro $\{[(N, N$-dimethylamino $)$ methyl $]$ phenyl- $C, N\}[1-(2,5-$ diisopropylphenyl)ethyldiphenylphosphine]palladium(II), ( \pm )-15 The racemic phosphine $\mathbf{1 1}$ as prepared from $\mathbf{1 0}(0.91 \mathrm{~g}, 4.05 \mathrm{mmol})$ and sodium diphenylphosphide (4.05 mmol) was added with achiral template $\mathbf{1}(1.12 \mathrm{~g}, 2.03$ $\mathrm{mmol})$ in dichloromethane $(5 \mathrm{~mL})$. The resulting yellow solution was stirred for $30 \mathrm{~min}$. The solvent was removed under reduced pressure to give a yellow solid. Recrystallization from dichloromethane-hexane gave orange crystals (1 g, 38\%). NMR calculated conversion: 90\%, calculated yield 43\%; mp 139-142 ${ }^{\circ} \mathrm{C}$; Anal. Calcd. for $\mathrm{C}_{35} \mathrm{H}_{43} \mathrm{ClNPPd}$ : C, 64.62; H, 6.66; N, 2.15. Found: C, 64.00; H, 6.68; $\mathrm{N}, 2.27 .{ }^{31} \mathrm{P}\left\{{ }^{1} \mathrm{H}\right\}$ NMR $\left(202 \mathrm{MHz}, \mathrm{CDCl}_{3}\right) \delta 51.0(\mathrm{~s})$.

\section{Dichlorodi- $\mu$-chlorobis[1-(2,5-}

diisopropylphenyl)ethyldiphenylphosphine]dipalladium(II), 13. Conc. $\mathrm{HCl}$ $(1 \mathrm{~mL})$ was added to a solution of $15(0.52 \mathrm{~g}, 0.79 \mathrm{mmol})$ in dichloromethane (5 mL). The yellow solution turned orange upon adding the conc. $\mathrm{HCl}$. The solution was stirred for an hour, and then quenched by water $(50 \mathrm{~mL})$. The organic phase was separated, further washed with water $(2 \times 50 \mathrm{~mL})$, dried with anhydrous $\mathrm{MgSO}_{4}$ and filtered. The solvent was removed under reduced 
pressure to give an orange solid $(0.43 \mathrm{~g}, 99 \%) .{ }^{31} \mathrm{P}\left\{{ }^{1} \mathrm{H}\right\} \mathrm{NMR}(202 \mathrm{MHz}$, $\left.\mathrm{CDCl}_{3}\right) \delta 43.0(\mathrm{~s}), 43.1(\mathrm{~s})$.

\section{Di- $\mu$-chlorobis\{1-[1-(diphenylphosphino)ethyl]-3,6-diisopropylphenyl-}

C,P \}dipalladium(II), 14. Product $13(0.43 \mathrm{~g}, 0.39 \mathrm{mmol})$ was suspended in ethanol $(50 \mathrm{~mL})$ with sodium acetate trihydrate $(1.7 \mathrm{~g})$. The mixture was heated at reflux for $2 \mathrm{~h}$, the solvent was then removed under reduced pressure. The crude product was redissolved in $\mathrm{DCM}$, washed with water $(50 \mathrm{~mL} \times 2)$ and dried with anhydrous $\mathrm{MgSO}_{4}$. The product was purified by silica gel column chromatography with hexanes/dichloromethane/acetone $(5: 1: 0.5, \mathrm{v} / \mathrm{v})$ as eluant to give a yellow solid $(0.19 \mathrm{~g}, 47 \%) .{ }^{31} \mathrm{P}\left\{{ }^{1} \mathrm{H}\right\}$ NMR $\left(202 \mathrm{MHz}, \mathrm{CDCl}_{3}\right) 4$ signals in ca. $3.5: 1: 1.2: 5.1$ ratio, $\delta 55.7(\mathrm{~s}), 56.2(\mathrm{~s}), 56.4(\mathrm{~s}), 57.3$ (s).

\section{[(S)-Prolinato]\{1-[1-(diphenylphosphino)ethyl]-3,6-diisopropylphenyl-}

$\boldsymbol{C , P}$ \}palladium(II), 16. The racemic complex $14(0.18 \mathrm{~g}, 0.17 \mathrm{mmol})$ in dichloromethane $(5 \mathrm{~mL})$ was added to a solution of excess potassium $(S)$ prolinate generated from $\mathrm{KOH}(0.02 \mathrm{~g})$ and $(S)$-proline $(0.04 \mathrm{~g})$ in methanol (5 $\mathrm{mL}$ ). The combined solution was stirred for $2 \mathrm{~h}$. The solvent was removed under reduced pressure, redissolved in dichloromethane, washed with water (50 $\mathrm{mL}$ x 2) and dried with anhydrous $\mathrm{MgSO}_{4}$. The dichloromethane was removed under reduced pressure to give a white solid. The products cannot be induced to crystallize despite the use of a variety of solvents. ${ }^{31} \mathrm{P}\left\{{ }^{1} \mathrm{H}\right\} \mathrm{NMR}(202 \mathrm{MHz}$, $\left.\mathrm{CDCl}_{3}\right) 4$ signals in ca. $4.1: 1.3: 2.3: 1$ ratio, $\delta 55.2(\mathrm{~s}), 54.6(\mathrm{~s}), 56.6(\mathrm{~s}), 60.4$ (s). 


\section{Chloro\{(S)-1-[1-(diphenylphosphino)ethyl]-3,6-diisopropylphenyl-}

$\boldsymbol{C , P}$ \}(triphenylphosphine)palladium(II), (S)-17. Triphenylphosphine $(0.08 \mathrm{~g}$ $0.31 \mathrm{mmol})$ was added to a solution of $(S, S)-14(0.16 \mathrm{~g}, 0.155 \mathrm{mmol})$ in dichloromethane $(5 \mathrm{~mL})$. After stirring for $30 \mathrm{~min}$, the solvent was removed under reduced pressure to give a yellow solid. The product cannot be induced to crystallize despite the use of a variety of solvents. ${ }^{31} \mathrm{P}\left\{{ }^{1} \mathrm{H}\right\}$ NMR $(202 \mathrm{MHz}$, $\left.\mathrm{CDCl}_{3}\right) \delta 19.8\left(\mathrm{~d},{ }^{2} J_{\mathrm{PP}}=444.4 \mathrm{~Hz}\right.$, coordinated $\mathrm{PPh}_{3}$ ligand of trans geometric isomer), $49.3\left(\mathrm{~d},{ }^{2} J_{\mathrm{PP}}=444.4 \mathrm{~Hz}\right.$, phosphapalladacycle $P$ of trans geometric isomer).

\section{[1,2-Bis(diphenylphosphino)ethane-P,P']\{(S)-1-[1-}

\section{(diphenylphosphino)ethyl]-3,6-diisopropylphenyl-C,P \}palladium(II)}

chloride, $(\boldsymbol{S})$-18. 1,2-Bis(diphenylphosphino)ethane $(0.1 \mathrm{~g}, 0.25 \mathrm{mmol})$ was added to a solution of $(S, S)-\mathbf{1 4}(0.13 \mathrm{~g}, 0.13 \mathrm{mmol})$ in dichloromethane $(5 \mathrm{~mL})$. After stirring for $1 \mathrm{~h}$, the solvent was removed under reduced pressure to give a yellow solid. The product was recrystallized from dichloromethane-hexane to give yellow crystals $(0.053 \mathrm{~g}, 23 \%) .{ }^{31} \mathrm{P}\left\{{ }^{1} \mathrm{H}\right\} \mathrm{NMR}\left(202 \mathrm{MHz}, \mathrm{CDCl}_{3}\right) \delta 33.3$ $\left(\mathrm{dd},{ }^{2} J_{\mathrm{P}-\mathrm{P}(\text { trans })}=358.0 \mathrm{~Hz},{ }^{2} J_{\mathrm{P}(\text { trans }) \mathrm{P}(\text { cis })}=30.1 \mathrm{~Hz}\right.$, coordinated dppe ligand $P$ trans to phosphapalladacycle $\mathrm{P}), 40.4\left(\mathrm{dd},{ }^{2} J_{\mathrm{P}(\text { trans }) \mathrm{P}(\text { cis })}=30.1 \mathrm{~Hz},{ }^{2} J_{\mathrm{P}-\mathrm{P}(\text { cis })}=\right.$ 15.7 Hz, coordinated dppe ligand $P$ cis to phosphapalladacycle P), 57.3 (dd, ${ }^{2} J_{\mathrm{P}-}$ $\mathrm{P}($ trans $)=358.0 \mathrm{~Hz},{ }^{2} J_{\mathrm{P}-\mathrm{P}(\text { cis })}=15.7 \mathrm{~Hz}$, phosphapalladacycle $\left.P\right)$.

\section{Bis(acetonitrile)\{(S)-1-[1-(diphenylphosphino)ethyl]-3,6-diisopropylphenyl-}

$\boldsymbol{C , P}$ \}palladium(II) hexafluorophosphate, $(\boldsymbol{S})$-19. The dimeric complex $(S, S)$ $14(0.11 \mathrm{~g}, 0.11 \mathrm{mmol})$ was dissolved in dichloromethane $(5 \mathrm{~mL})$ and acetonitrile $(1 \mathrm{~mL})$. A solution of silver(II) hexafluorophosphate $(0.068 \mathrm{~g}, 0.27$ mmol, 2.4 equiv.) in water $(1 \mathrm{~mL})$ was added. The mixture was stirred 
vigorously for $2 \mathrm{~h}$ in darkness. The crude product was filtered through Celite, washed with water $\left(50 \mathrm{~mL}\right.$ x 2) and dried with anhydrous $\mathrm{MgSO}_{4}$. The solvent was removed to give a yellow solid $(0.077 \mathrm{~g}, 49 \%)$. mp $112-114{ }^{\circ} \mathrm{C}$ (dec); ${ }^{31} \mathrm{P}\left\{{ }^{1} \mathrm{H}\right\} \mathrm{NMR}\left(162 \mathrm{MHz}, \mathrm{CDCl}_{3}\right) \delta 60.1$ (s), -144.3 (septet, $\left.J=712.1 \mathrm{~Hz}, \mathrm{PF}_{6}{ }^{-}\right)$.

Asymmetric catalytic hydrophosphination of trans-chalcone, 20 with diphenylphosphine. Formation of 3-(diphenylphosphino)-1,3diphenylpropan-1-one, 21. To a solution of diphenylphosphine $(0.070 \mathrm{~g}, 0.37$ mmol) in dichloromethane $(5 \mathrm{~mL})$, the catalyst $(S)-19(0.013 \mathrm{~g}, 0.0187 \mathrm{mmol}, 5$ mol\%) was added. The solution was stirred at r.t. for 5 min and then was cooled to $-80{ }^{\circ} \mathrm{C}$. Subsequently, 20 (0.086 g, $0.41 \mathrm{mmol}, 1.1$ equiv.) was added, followed by $\mathrm{Et}_{3} \mathrm{~N}(0.019 \mathrm{~g}, 0.0187 \mathrm{mmol}, 0.5$ equiv.) in DCM (1 mL) dropwise. The solution was subsequently stirred at $-80{ }^{\circ} \mathrm{C}$ and the reaction was monitored by ${ }^{31} \mathrm{P}\left\{{ }^{1} \mathrm{H}\right\}$ NMR. The reaction was found to be completed at $20 \mathrm{~h}$. NMR calculated yield: $95 \% ;{ }^{31} \mathrm{P}\left\{{ }^{1} \mathrm{H}\right\}$ NMR $\left(202 \mathrm{MHz}, \mathrm{CDCl}_{3}\right) \delta-1.7$ (s).

Determination of ee of 21 by coordination to $(\boldsymbol{R})-\mathbf{4}$. The complex $(R)-4(0.14$ g, 0.205 mmol, 0.55 equiv.) in DCM (5 mL) was added to the free phosphine 21. The solvent was removed to give a yellow solid. ${ }^{31} \mathrm{P}\left\{{ }^{1} \mathrm{H}\right\} \mathrm{NMR}(202 \mathrm{MHz}$, $\left.\mathrm{CDCl}_{3}\right) \delta 44.9$ (s), 49.0 (s) in $1: 1.34$ ratio, $14.5 \%$ ee.

(9-Phenanthryl)phenylphosphine, 22. Mg turnings (0.7 g, 29 mmol, 1.5 equiv. of 9-phenanthryl bromide) and a few $\mathrm{I}_{2}$ crystals were heated while stirring in dry THF $(25 \mathrm{~mL})$ until the mixture turned cloudy and slightly yellow. A solution of 9-phenanthryl bromide (5 g, $19 \mathrm{mmol})$ in dry THF $(20 \mathrm{~mL})$ was added dropwise into the mixture. The brown mixture was heated for $1 \mathrm{~h}$ and allowed to cool down to r.t. The resulting Grignard reagent was added dropwise 
to a solution of dichlorophenylphosphine in dry THF at $-78{ }^{\circ} \mathrm{C}$ over a period of $3 \mathrm{~h}$, followed by an excess of $\mathrm{LiAlH}_{4}$ at $-78^{\circ} \mathrm{C}$, yielding a grey suspension. The mixture was allowed to warm up to r.t. and stirred for another $2 \mathrm{~h}$. The reaction was quenched by a cautious addition of $\mathrm{NH}_{4} \mathrm{Cl}$ in degassed water, followed by the removal of THF by distillation. The product was extracted with diethyl ether $(3 \times 50 \mathrm{~mL})$ and the combined organic layers were dried with anhydrous $\mathrm{MgSO}_{4}$. The diethyl ether was removed by distillation to give a white solid as product $(5.2 \mathrm{~g}, 93 \%) .{ }^{31} \mathrm{P}\left\{{ }^{1} \mathrm{H}\right\} \mathrm{NMR}\left(202 \mathrm{MHz}, \mathrm{CDCl}_{3}\right) \delta-48.0(\mathrm{~s})$.

\section{[4-(2,5-Diphenylphenol)oxy](9-phenanthryl)phenylphosphine, 23. To a} solution of (9-phenanthryl)phenylphosphine $(0.098 \mathrm{~g}, 0.34 \mathrm{mmol})$ in degassed DCM (7 mL), the catalyst $(S)-7(0.011 \mathrm{~g}, 0.017 \mathrm{mmol}, 5 \mathrm{~mol} \%)$ was added. The solution was stirred at r.t. for $2 \mathrm{~min}$ before it was cooled to $-80{ }^{\circ} \mathrm{C}$. $2,5-$ Diphenyl-1,4-benzoquinone (0.098 g, $0.38 \mathrm{mmol}, 1.1$ equiv.) was added, followed by dropwise addition of $\mathrm{Et}_{3} \mathrm{~N}(0.034 \mathrm{~g}, 0.34 \mathrm{mmol})$ in the solvent $(0.5$ $\mathrm{mL})$. The solution was subsequently stirred for $12 \mathrm{~h}$ and the ${ }^{31} \mathrm{P}\left\{{ }^{1} \mathrm{H}\right\} \mathrm{NMR}$ spectrum was recorded. ${ }^{31} \mathrm{P}\left\{{ }^{1} \mathrm{H}\right\} \mathrm{NMR}\left(202 \mathrm{MHz}, \mathrm{CDCl}_{3}\right) \delta 111.0$ (s).

[4-(2,5-Diphenylphenol)oxy](9-phenanthryl)phenylphosphine sulfide, 24. Excess sulfur was added to $\mathbf{2 3}$. The solvent was removed and the crude product was purified by silica gel column chromatography to give a yellow solid $(0.097$ g, 49\%). mp 184-186 ${ }^{\circ} \mathrm{C} ;{ }^{31} \mathrm{P}\left\{{ }^{1} \mathrm{H}\right\}$ NMR (202 MHz, $\left.\mathrm{CDCl}_{3}\right) \delta 80.0$ (s). HPLC (Daicel Chiralpak IC), hexane/IPA = 98/2, flow $1.0 \mathrm{~mL} / \mathrm{min}, 280 \mathrm{~nm}, t_{l}=36.9$ $\min$ (minor), $t_{2}=40.7 \mathrm{~min}$ (major) for $27 \%$ ee.

[4-(2,5-Diphenylphenol)oxy](1-naphthyl)phenylphosphine, 26. To a solution of (1-naphthyl)phenylphosphine $(0.06 \mathrm{~g}, 0.26 \mathrm{mmol})$ in degassed solvent (7 
$\mathrm{mL})$, the catalyst $(S)-19(0.009 \mathrm{~g}, 0.013 \mathrm{mmol}, 5 \mathrm{~mol} \%)$ was added. The solution was stirred at r.t. for 2 min before it was cooled to $-45{ }^{\circ} \mathrm{C}$. $2,5-$ Diphenyl-1,4-benzoquinone (0.073 g, $0.28 \mathrm{mmol}, 1.1$ equiv.) was added, followed by dropwise addition of $\mathrm{Et}_{3} \mathrm{~N}(0.026 \mathrm{~g}, 0.26 \mathrm{mmol})$ in the solvent $(0.5$ $\mathrm{mL})$. The solution was subsequently stirred for $12 \mathrm{~h}$ and the ${ }^{31} \mathrm{P}\left\{{ }^{1} \mathrm{H}\right\} \mathrm{NMR}$ spectrum was recorded. ${ }^{31} \mathrm{P}\left\{{ }^{1} \mathrm{H}\right\} \mathrm{NMR}\left(202 \mathrm{MHz}, \mathrm{CDCl}_{3}\right) \delta 110.2$ (s).

[4-(2,5-Diphenylphenol)oxy](1-naphthyl)phenylphosphine sulfide, 27. Excess sulfur was added to $\mathbf{2 6}$. The solvent was removed and the crude product was purified by silica gel column chromatography to give a yellow solid $(0.085$ g, 63\%). ${ }^{31} \mathrm{P}\left\{{ }^{1} \mathrm{H}\right\}$ NMR (202 MHz, $\left.\mathrm{CDCl}_{3}\right) \delta 81.1$ (s). HPLC (Daicel Chiralpak AD-H), hexane/IPA = 95/5, flow $1.0 \mathrm{~mL} / \mathrm{min}, 280 \mathrm{~nm}, t_{1}=39.8 \mathrm{~min}$ (major), $t_{2}$ $=46.2 \min ($ minor $)$ for $51 \%$ ee. 


\section{CHAPTER 3: SYNTHESIS OF CP- PALLADACYCLES FROM CHIRAL PHOSPHINES VIA CATALYTIC ASYMMETRIC HYDROPHOSPHINATION REACTION}

\subsection{Introduction}

Asymmetric hydrophosphination reaction controlled by a chiral template has been found to be an efficient way of generating a large class of chiral phosphines.

The multi-step approach to synthesize chiral phosphapalladacycles involves the synthesis of a racemic phosphine followed by a tedious optical resolution process.

In this chapter, a new method of synthesizing CP-palladacycles from catalytic asymmetric hydrophosphination reaction is explored. Through the optimization of reaction conditions, the chiral phosphines produced from the reaction can be directly cyclopalladated without the need of optical resolution. As 1-naphthyl-based palladacycles had been very effective in controlling stereoselectivity, a 1-naphthyl-based enone is used in the hydrophosphination reactions to synthesize 1-naphthyl-based palladacycles.

\subsection{Research Objectives}

The research objectives are to synthesize phosphapalladacycles from the phosphine products of catalytic asymmetric hydrophosphination reaction of 1naphthyl based enones. The reaction conditions of hydrophosphination reaction are screened to optimize conditions for enantioenriched or enantiopure 
phosphine products, reducing the complexities or eliminating the need to separate the enantiomers of the products.

The catalytic asymmetric hydrophosphination is extended to use a Pchiral secondary phosphine, $o$-anisylphenylphosphine, in place of diphenylphosphine, resulting in $\mathrm{C}^{*}$ - $\mathrm{P}^{*}$ phosphapalladacycles with two chiral centres at the carbon and phosphorus atoms.

\subsection{Results and Discussion}

\subsubsection{Asymmetric catalytic hydrophosphination reaction with diphenylphosphine}

Diphenylphosphine was dissolved in degassed dichloromethane and the catalyst (10-20 mol\%) was added. The reaction was cooled to $-80{ }^{\circ} \mathrm{C}$ and $E-3-$ (1-naphthyl)-1-(4-chlorophenyl)-2-propen-1-one $\mathbf{2 8}$ was added. This was followed by the dropwise addition of the base triethylamine into the reaction mixture. The reaction was monitored by ${ }^{31} \mathrm{P}\left\{{ }^{1} \mathrm{H}\right\}$ NMR spectroscopy (Scheme $3.1)$.<smiles>CCN(CC)CCCCC(C)(C)C</smiles>

Scheme 3.1

Table 3.1 Screening of reaction conditions for the formation of 29

\begin{tabular}{ccccccc}
\hline Entry & Catalyst & Cat mol \% & Time $(\mathrm{h})$ & Yield $(\%)^{\mathrm{a}}$ & Major isomer & ee $(\%)$ \\
\hline 1 & $(R)-5$ & 20 & 2 & 71 & $S$ & 66 \\
2 & $(S)-7$ & 10 & 26 & 83 & $R$ & 70 \\
\hline${ }^{\mathrm{a}}$ Calculated from ${ }^{31} \mathrm{P}\left\{{ }^{1} \mathrm{H}\right\}$ NMR. & & &
\end{tabular}


As shown in Table 3.1, the reaction was first carried out using the $(R)-5$ catalyst with $20 \mathrm{~mol} \%$ equivalent. The reaction was found to be completed within 2 hours. Monitoring by ${ }^{31} \mathrm{P}\left\{{ }^{1} \mathrm{H}\right\}$ NMR showed a single peak at $\delta$ 2.0.

The reaction was repeated using the $(S)-7$ catalyst under the same reaction conditions but with only $10 \mathrm{~mol} \%$ equivalent. The reaction took 26 hours to complete due to the low amount of catalyst used.

The reaction yield is calculated from the integration values of the various phosphorus peaks in the NMR spectra. It was found that the reaction catalyzed by $(S)-7$ showed a higher yield at $83 \%$.

\subsubsection{Coordination to $(R)-4$ and cyclopalladation of 29}

From entry 1, the enantioenriched free phosphine $\mathbf{2 9}$ was coordinated to $(R)-\mathbf{4}$, and the resulting complexes were separated by column chromatography and fractional crystallization (Scheme 3.2). 


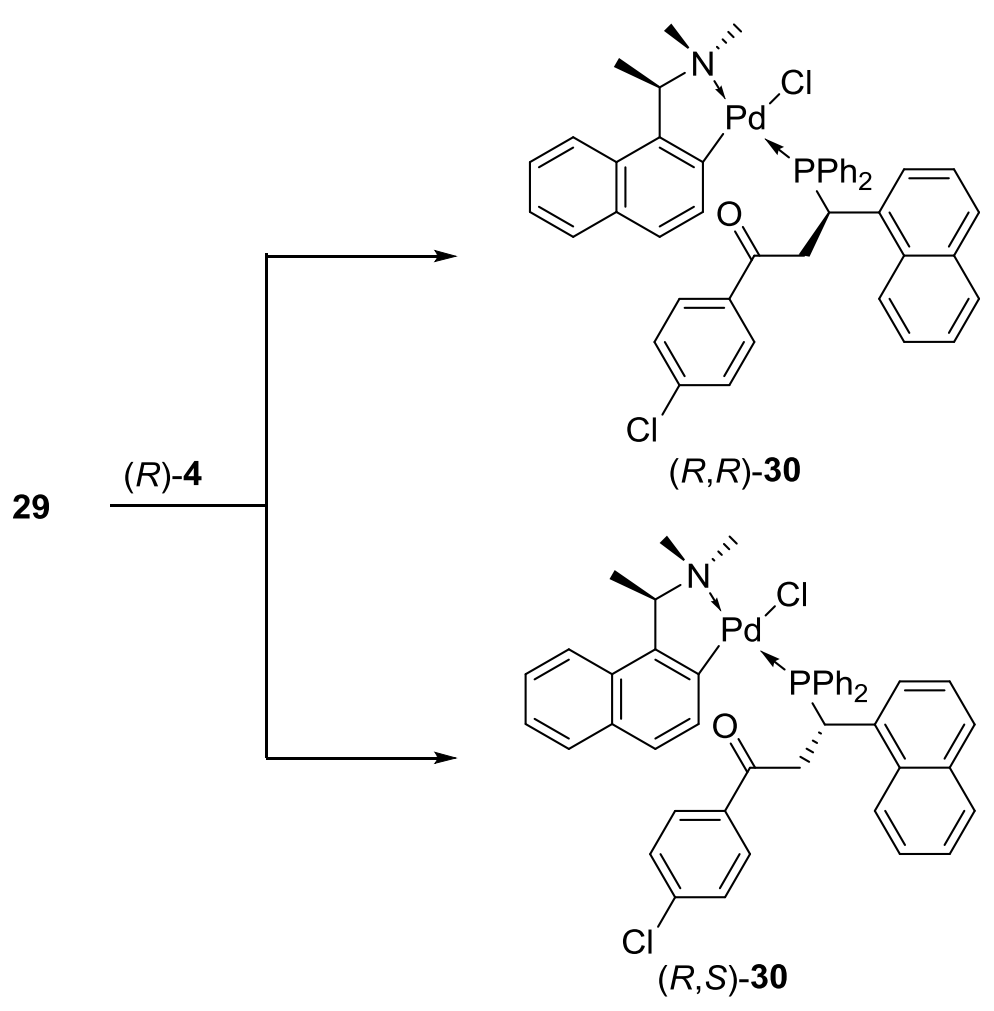

Scheme 3.2

Both diastereomers $(R, R)$-30 and $(R, S)$-30 were successfully crystallized as yellow crystals. The less soluble major product $(R, S)-\mathbf{3 0}$ crystallized first and X-ray crystallography was performed to confirm the stereoconfiguration (Figure 3.1). 


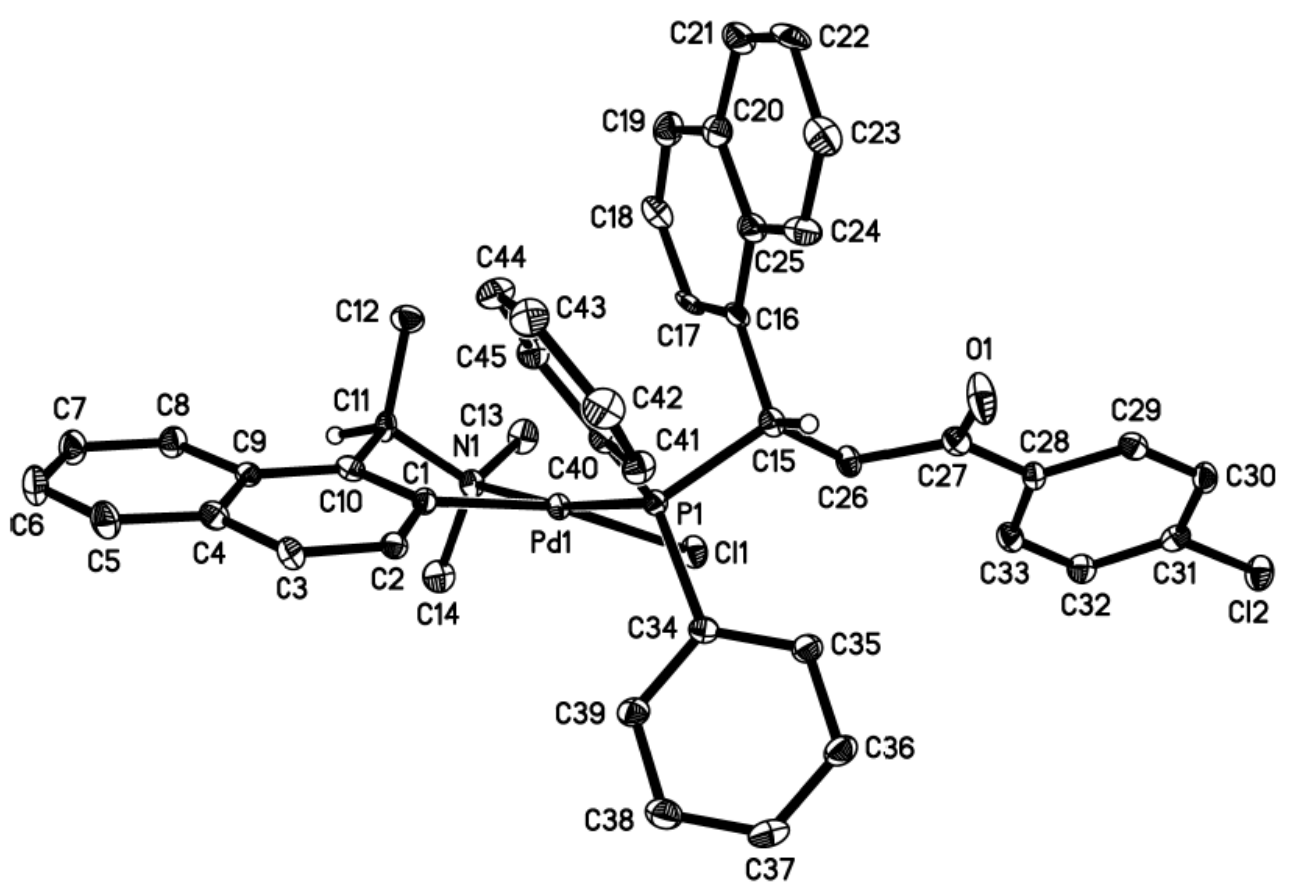

Figure 3.1 X-ray molecular structure of $(R, S)-30$

Table 3.2 Selected bond lengths $(\AA)$ and angles $\left(^{\circ}\right)$ of $(R, S)-30$

\begin{tabular}{llll}
\hline $\mathrm{Pd}(1)-\mathrm{C}(1)$ & $1.999(3)$ & $\mathrm{Pd}(1)-\mathrm{N}(1)$ & $2.134(3)$ \\
$\mathrm{Pd}(1)-\mathrm{P}(1)$ & $2.2552(8)$ & $\mathrm{Pd}(1)-\mathrm{Cl}(1)$ & $2.4234(7)$ \\
$\mathrm{C}(11)-\mathrm{N}(1)$ & $1.511(4)$ & $\mathrm{C}(13)-\mathrm{N}(1)$ & $1.493(4)$ \\
$\mathrm{C}(14)-\mathrm{N}(1)$ & $1.490(4)$ & $\mathrm{C}(15)-\mathrm{P}(1)$ & $1.858(3)$ \\
$\mathrm{C}(34)-\mathrm{P}(1)$ & $1.837(3)$ & $\mathrm{C}(40)-\mathrm{P}(1)$ & $1.834(3)$ \\
$\mathrm{C}(15)-\mathrm{C}(16)$ & $1.526(8)$ & $\mathrm{C}(16)-\mathrm{C}(17)$ & $1.381(9)$ \\
$\mathrm{C}(15)-\mathrm{C}(26)$ & $1.532(4)$ & $\mathrm{C}(26)-\mathrm{C}(27)$ & $1.504(5)$ \\
$\mathrm{C}(27)-\mathrm{O}(1)$ & $1.214(4)$ & $\mathrm{C}(27)-\mathrm{C}(28)$ & $1.497(4)$ \\
& & & \\
$\mathrm{C}(1)-\mathrm{Pd}(1)-\mathrm{N}(1)$ & $81.22(11)$ & $\mathrm{C}(1)-\mathrm{Pd}(1)-\mathrm{P}(1)$ & $96.82(9)$ \\
$\mathrm{N}(1)-\mathrm{Pd}(1)-\mathrm{P}(1)$ & $169.86(8)$ & $\mathrm{C}(1)-\mathrm{Pd}(1)-\mathrm{Cl}(1)$ & $164.22(9)$ \\
$\mathrm{N}(1)-\mathrm{Pd}(1)-\mathrm{Cl}(1)$ & $91.86(7)$ & $\mathrm{P}(1)-\mathrm{Pd}(1)-\mathrm{Cl}(1)$ & $92.38(3)$ \\
$\mathrm{C}(40)-\mathrm{P}(1)-\mathrm{Pd}(1)$ & $118.58(10)$ & $\mathrm{C}(34)-\mathrm{P}(1)-\mathrm{Pd}(1)$ & $115.39(11)$ \\
$\mathrm{C}(15)-\mathrm{P}(1)-\mathrm{Pd}(1)$ & $115.19(10)$ & $\mathrm{C}(16)-\mathrm{C}(15)-\mathrm{P}(1)$ & $107.6(3)$ \\
$\mathrm{C}(17)-\mathrm{C}(16)-\mathrm{C}(15)$ & $118.9(7)$ & $\mathrm{C}(16)-\mathrm{C}(15)-\mathrm{C}(26)$ & $111.4(3)$ \\
$\mathrm{C}(27)-\mathrm{C}(26)-\mathrm{C}(15)$ & $112.2(3)$ & $\mathrm{O}(1)-\mathrm{C}(27)-\mathrm{C}(28)$ & $120.5(3)$ \\
$\mathrm{O}(1)-\mathrm{C}(27)-\mathrm{C}(26)$ & $122.1(3)$ & $\mathrm{C}(28)-\mathrm{C}(27)-\mathrm{C}(26)$ & $117.5(3)$ \\
\hline
\end{tabular}

The X-ray crystallographic study showed that the chiral centre at $\mathrm{C}(15)$ adopts the $S$ configuration. 
The naphthylamine auxiliary on $(R, S)$-30 was removed by concentrated hydrochloric acid and the resulting complex $(S, S)-31$ was refluxed in ethanol in the presence of sodium acetate trihydrate to give the ortho-palladated product (S,S)-32 (Scheme 3.3).

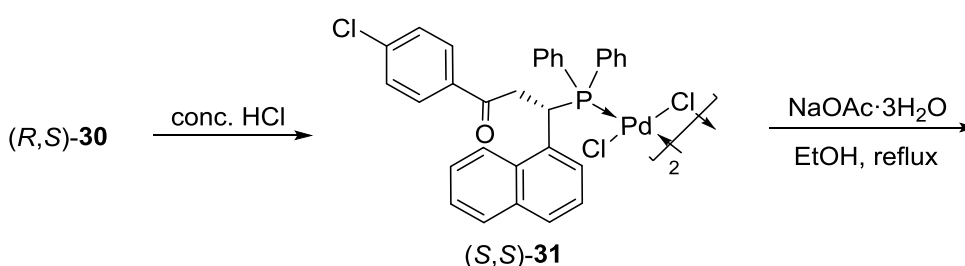

Scheme 3.3

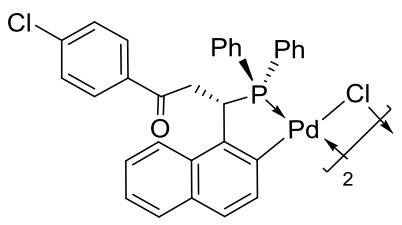

$(S, S)-32$

3.3.1.3 Coordination to 1 and cyclopalladation of 29

Cyclopalladation of $\mathbf{2 9}$ generated from entry 1 was attempted by using the achiral benzylamine complex $\mathbf{1}$ in place of the naphthylamine complex $(R)$ 4 (Scheme 3.4).

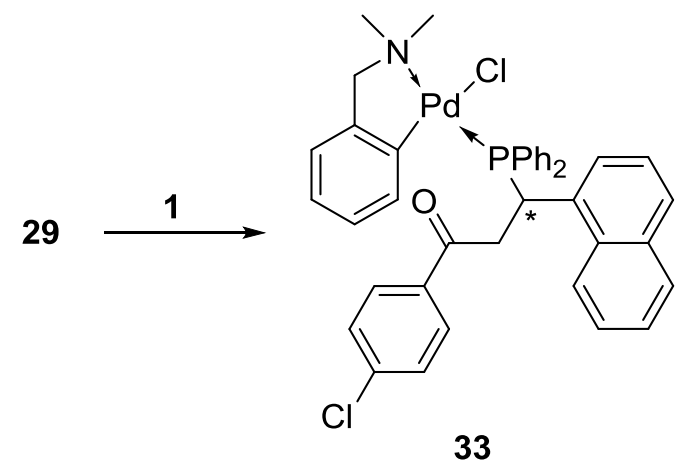

\section{Scheme 3.4}

The resulting complex $\mathbf{3 3}$ was treated with concentrated hydrochloric acid to remove the benzylamine auxiliary, and then refluxed in ethanol in the presence of sodium acetate trihydrate to give the enantioenriched dimer $\mathbf{3 2}$ (Scheme 3.5). 


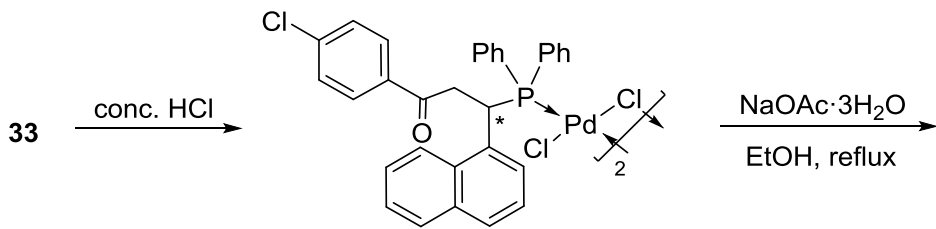

31

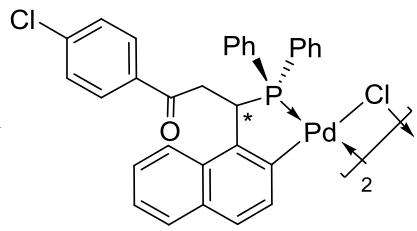

32

Scheme 3.5

The ortho-palladated dimer product 32 was coordinated to $(S)$-proline to attempt separation of the enantiomers (Scheme 3.6).

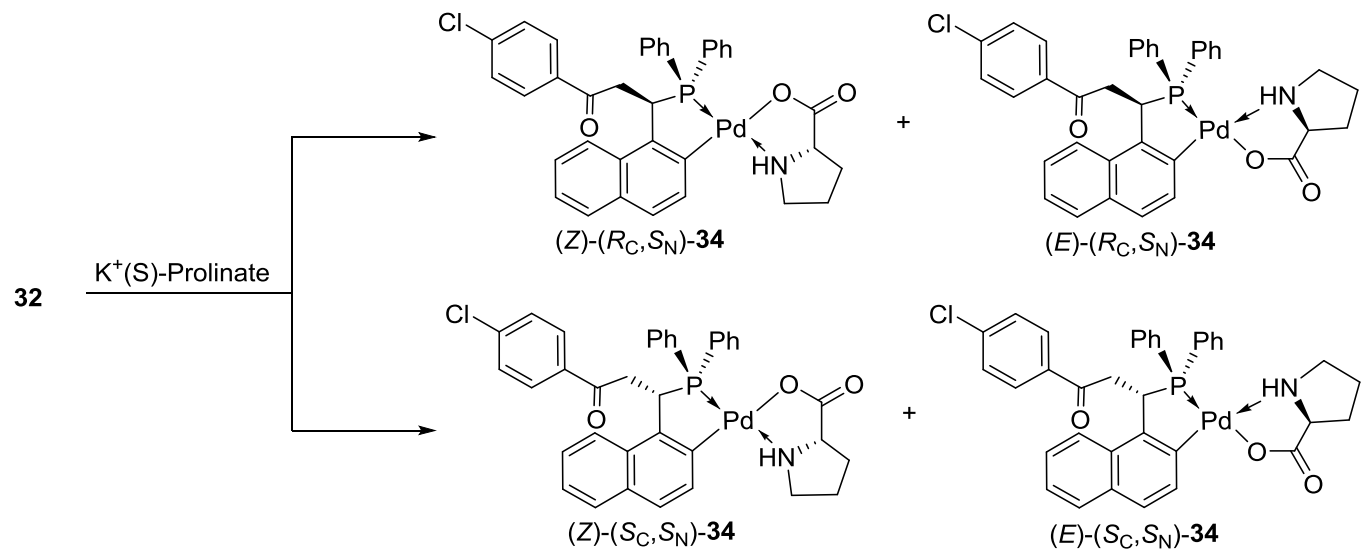

Scheme 3.6

The major isomers $(\mathrm{Z}) /(E)-\left(S_{\mathrm{C}}, S_{\mathrm{N}}\right)-\mathbf{3 4}$ were crystallized first to give white crystals, but the crystals were not suitable for X-ray crystallographic study. The stereoconfiguration of the crystallized product was corroborated by the coordination of $(S, S)$-32 as synthesized in section 3.3.1.2 to $(S)$-proline and the ${ }^{31} \mathrm{P}\left\{{ }^{1} \mathrm{H}\right\}$ NMR spectra were compared.

$(\mathrm{Z}) /(E)-\left(S_{\mathrm{C}}, S_{\mathrm{N}}\right)-34$ can be converted to the dichloro-bridged dimer $(S, S)$ 32 with the treatment of $1 \mathrm{M}$ hydrochloric acid to remove the $(S)$-proline auxiliary (Scheme 3.7). 


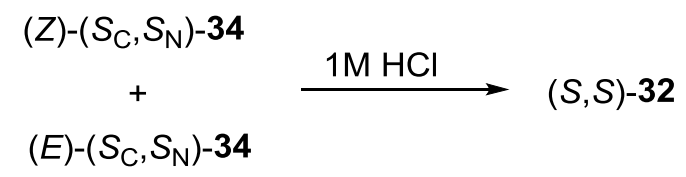

\section{Scheme 3.7}

\subsubsection{Coordination of $(S, S)$-32 with triphenylphosphine and dppe}

The properties of $(S, S)$-32 were studied by coordination to triphenylphosphine and 1,2-bis(diphenylphosphino)ethane (dppe).

Triphenylphosphine was added to $(S, S)$-14 to give a mixture of trans and cis products (Scheme 3.8).

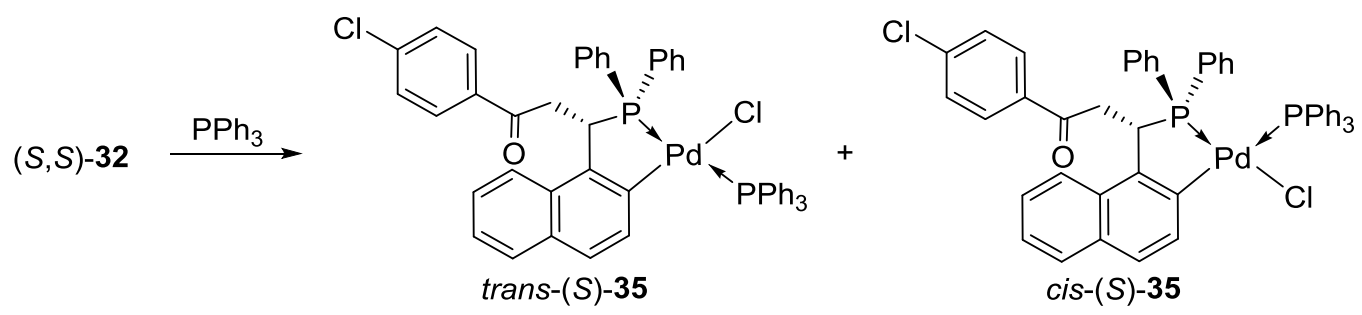

\section{Scheme 3.8}

The ${ }^{31} \mathrm{P}\left\{{ }^{1} \mathrm{H}\right\}$ NMR spectrum indicates the formation of a mixture of cis $(\delta 63.7$ and 17.0) and trans-(P,P) $(\delta 53.2$ and 25.6) isomers in the ratio of $1.4: 1$ in favour of the cis isomer. The peaks can be identified by their ${ }^{2} \mathbf{J}_{\mathrm{P}, \mathrm{P}}$ coupling constants. These were determined to be $26.7 \mathrm{~Hz}$ for cis- $(S)-35$ and $424.9 \mathrm{~Hz}$ for trans-(S)-35. (Figure 3.2) 


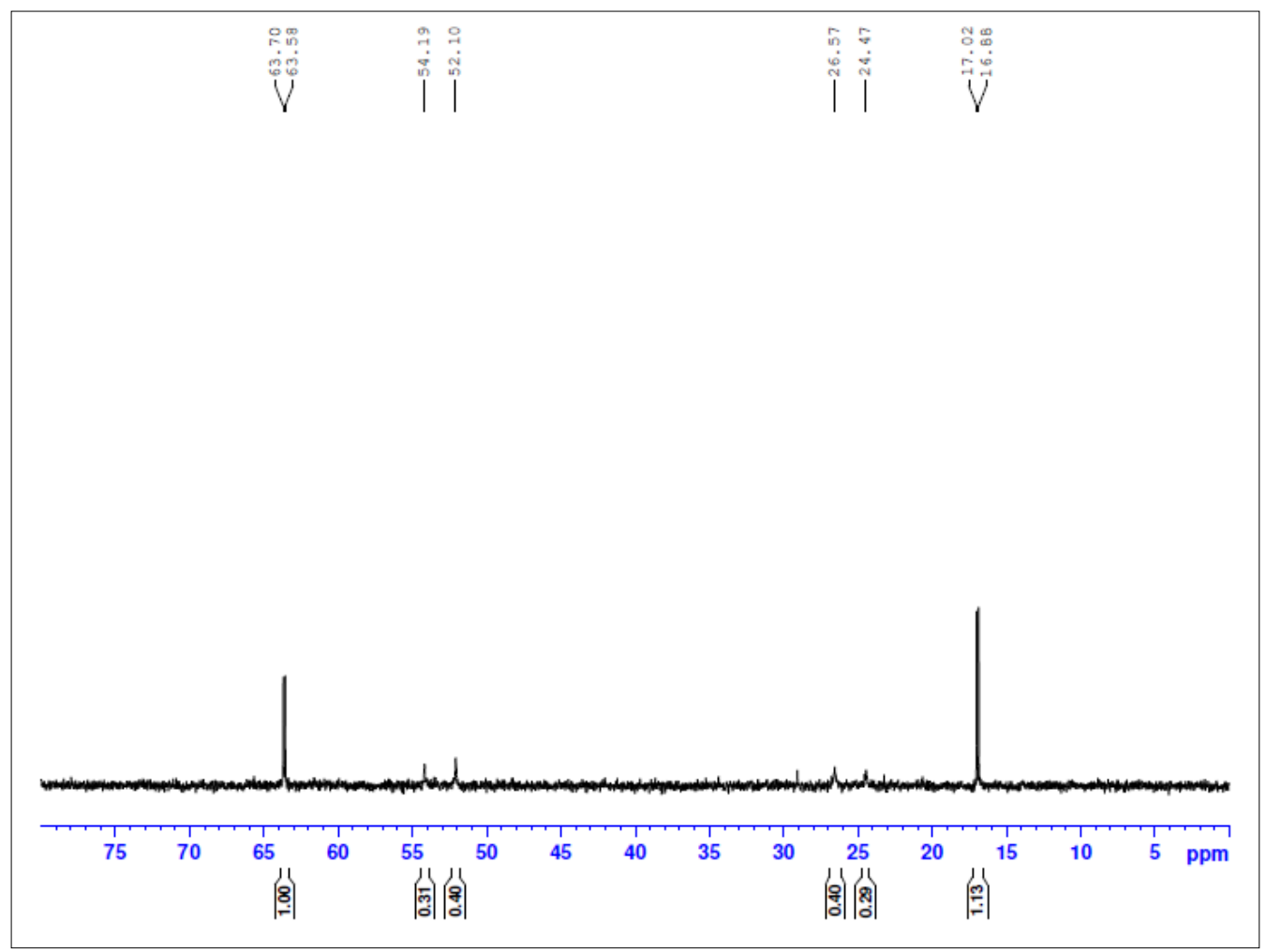

Figure 3.2 ${ }^{31} \mathrm{P}\left\{{ }^{1} \mathrm{H}\right\}$ NMR spectrum of $(S)-35\left(\mathrm{CDCl}_{3}, 202 \mathrm{MHz}\right)$

The bidentate ligand dppe was coordinated to $(S, S)$-32 to form the monomer complex $(S)$-36 (Scheme 3.9).

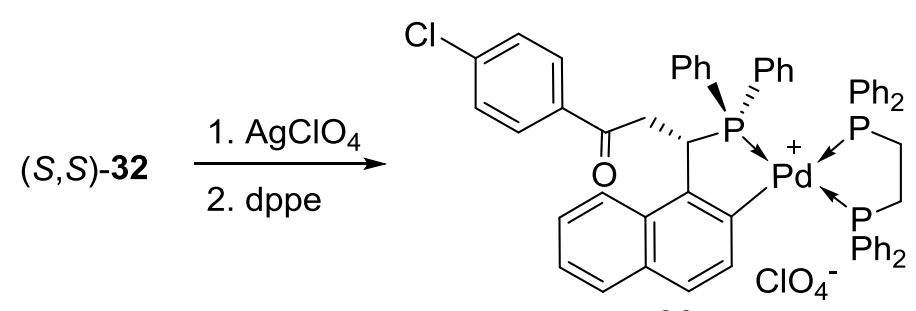

(S)-36

\section{Scheme 3.9}

Attempts to obtain crystals of $(S)$-35 and $(S)$-36 for X-ray crystallographic studies were unsuccessful. 


\subsubsection{Asymmetric catalytic hydrophosphination reaction with o- anisylphenylphosphine}

The hydrophosphination reaction was extended to use $o$ anisylphenylphosphine in place of diphenylphosphine. The resulting free phosphine 37 has 2 chiral centres, giving 4 possible products (Scheme 3.10).<smiles>O=C(/C=C/c1cccc2ccccc12)c1ccc(Cl)cc1</smiles>

28<smiles>COc1ccccc1Pc1ccccc1</smiles><smiles></smiles><smiles>CCC(CC(=O)c1ccc(Cl)cc1)c1cccc2ccccc12</smiles>

Scheme 3.10

Table 3.3 Screening of reaction conditions for the formation of $\mathbf{3 7}$

\begin{tabular}{|c|c|c|c|c|c|c|}
\hline Entry & Catalyst & Cat mol \% & Solvent & Time (d) & Conversion $(\%)^{\mathrm{a}}$ & Yield $(\%)^{\mathrm{b}}$ \\
\hline 1 & $(R)-5$ & 15 & $\mathrm{CH}_{2} \mathrm{Cl}_{2}$ & 2 & 96 & 71 \\
\hline 2 & $(R)-5$ & 15 & $\mathrm{CHCl}_{3}$ & 2 & 97 & 81 \\
\hline 3 & $(R)-5$ & 15 & THF & 1 & 99 & 68 \\
\hline 4 & $(R)-5$ & 15 & Acetone & 2 & 99 & 76 \\
\hline 5 & $(S)-7$ & 10 & $\mathrm{CH}_{2} \mathrm{Cl}_{2}$ & 4 & 93 & 79 \\
\hline 6 & $(S)-7$ & 10 & $\mathrm{CHCl}_{3}$ & 2.5 & 99 & 82 \\
\hline 7 & $(S)-7$ & 10 & THF & 7 & 95 & 48 \\
\hline 8 & $(S)-7$ & 10 & Acetone & 5 & 97 & 83 \\
\hline
\end{tabular}

Compared to the hydrophosphination reaction of $\mathbf{2 8}$ with diphenylphosphine, the reaction with $o$-anisylphenylphosphine proceeded much more slowly, taking about 2 days to complete at room temperature.

\subsubsection{Coordination to $(R)-4$ and cyclopalladation of 37}

The free phosphines 37 were coordinated to $(R)-\mathbf{4}$ and the ${ }^{31} \mathrm{P}$ NMR spectrum $\left(202 \mathrm{MHz}, \mathrm{CDCl}_{3}\right)$ was recorded. However, instead of four peaks as 
expected with 4 diastereomers, only two major peaks at $\delta 55.7$ and $\delta 58.3$ were observed in the NMR spectrum (Scheme 3.11).

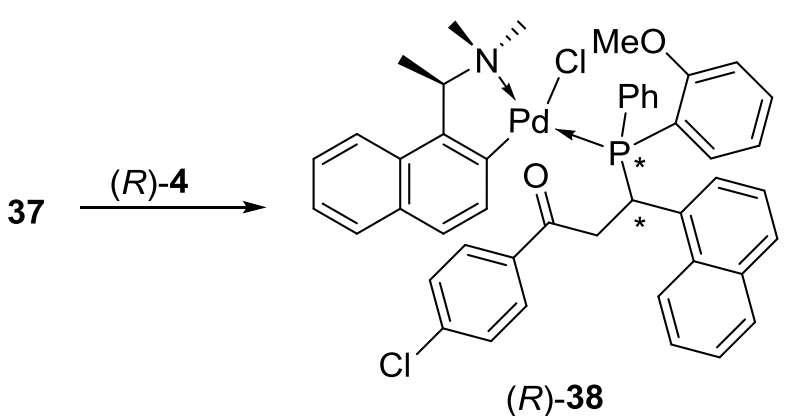

$(R)-38$

Chemical shifts in ${ }^{31} \mathrm{P}\left\{{ }^{1} \mathrm{H}\right\}$ NMR $\left(202 \mathrm{MHz}, \mathrm{CHCl}_{3}\right): \delta 55.7=(R)-38 \mathbf{a}$

$\delta 58.3=(R)-38 b$

\section{Scheme 3.11}

The compounds identified by the two NMR peaks (hereinafter referred to as $(R)$-38a for $\delta 55.7$ and $(R)$-38b for $\delta 58.3$ when coordinated with $(R)-4)$ were separated by column chromatography. Attempts to recrystallize either compound were unsuccessful.

Ortho-palladation of the major product $(R)-\mathbf{3 8 b}$ was attempted based on the method of synthesizing $(S)$-6. Firstly, the naphthylamine auxiliary was removed by concentrated hydrochloric acid, followed by refluxing the dimer product 39 with sodium acetate trihydrate in ethanol, giving the dimer product 40 (Scheme 3.12). 


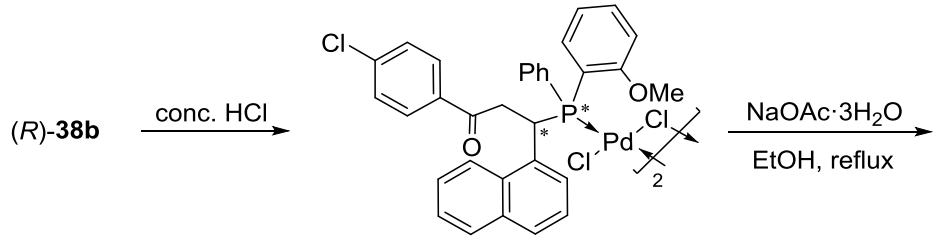

39

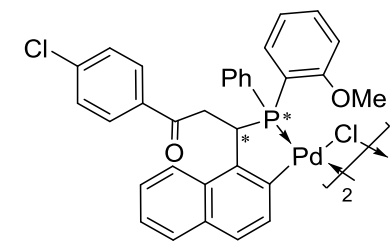

40

Scheme 3.12

Despite numerous attempts, $\mathbf{4 0}$ was unable to be induced to crystallized.

Compound 40 was coordinated to triphenylphosphine to form compound 41 (Scheme 3.13).

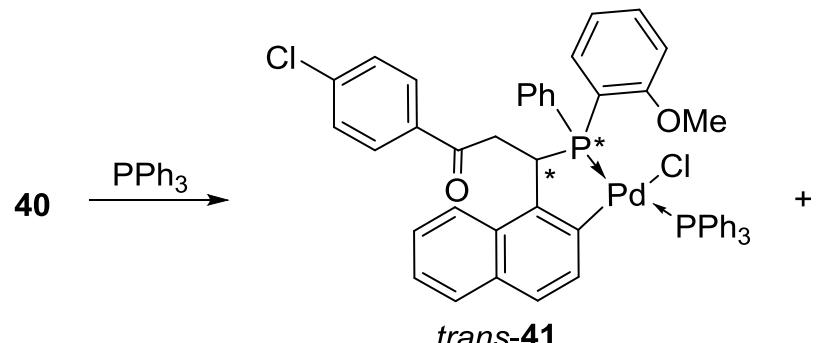

trans-41

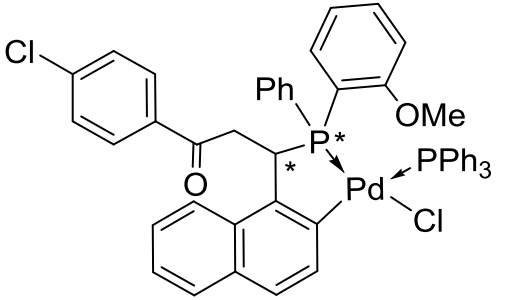

cis-41

\section{Scheme 3.13}

The ${ }^{31} \mathrm{P}\left\{{ }^{1} \mathrm{H}\right\}$ NMR spectrum indicated the formation of both cis- $(\delta 53.9$ and 17.6) and trans- $\left(R_{\mathrm{C}}, R_{\mathrm{P}}\right)-\mathbf{1 4}(\delta 49.5$ and 25.5$)$ in the ratio of 1:1.6 in favour of the trans isomer. ${ }^{2} \mathrm{~J}_{\mathrm{P}, \mathrm{P}}$ coupling constants are $26.3 \mathrm{~Hz}$ for the cis isomer and 427.2 $\mathrm{Hz}$ for the trans isomer (Figure 3.3). 


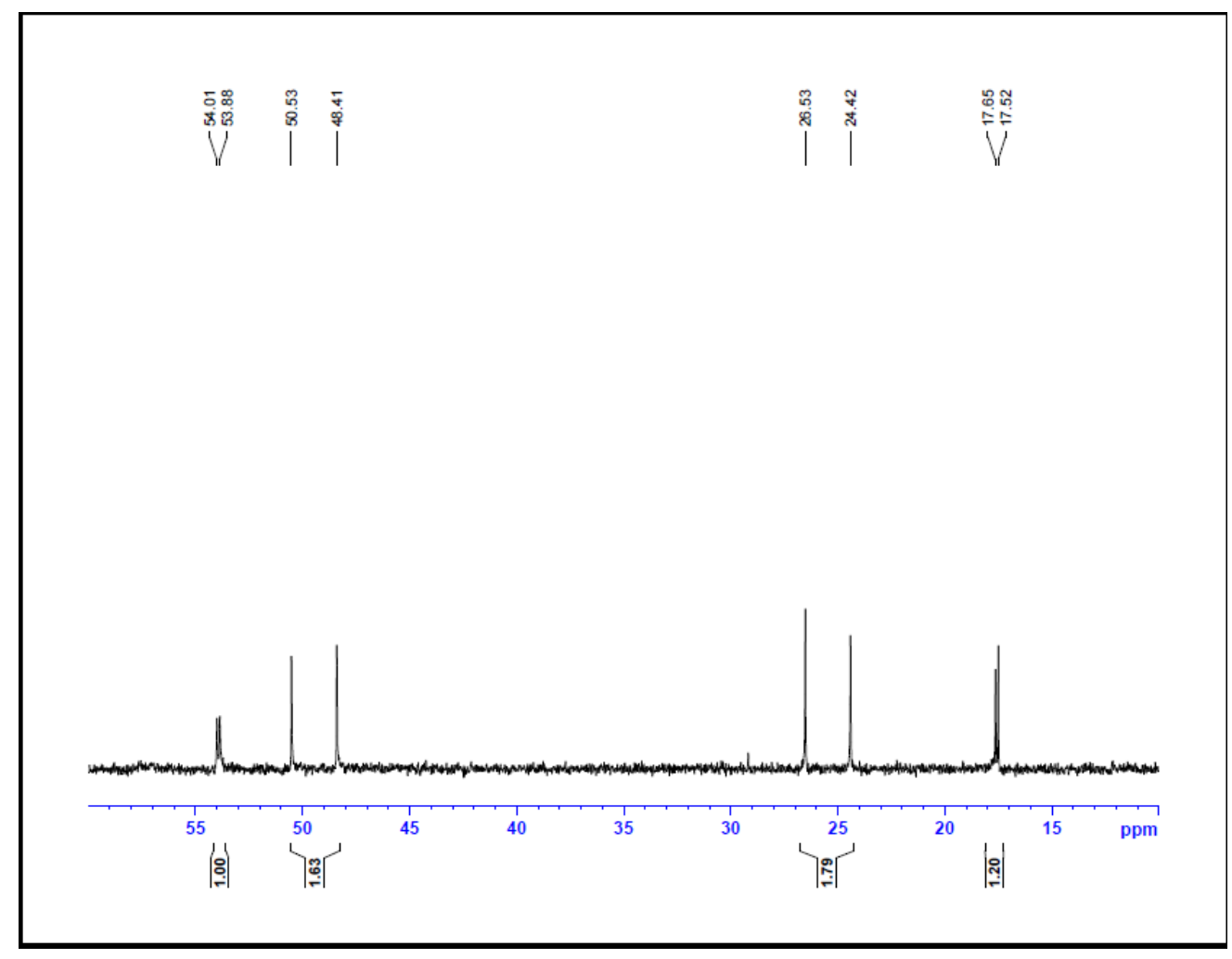

Figure $3.3{ }^{31} \mathbf{P}\left\{{ }^{1} \mathrm{H}\right\}$ NMR spectrum of $41\left(\mathrm{CDCl}_{3}, 202 \mathrm{MHz}\right)$

Compound 41 was recrystallized from dichloromethane-hexane and Xray crystallography was performed (Figure 3.4).

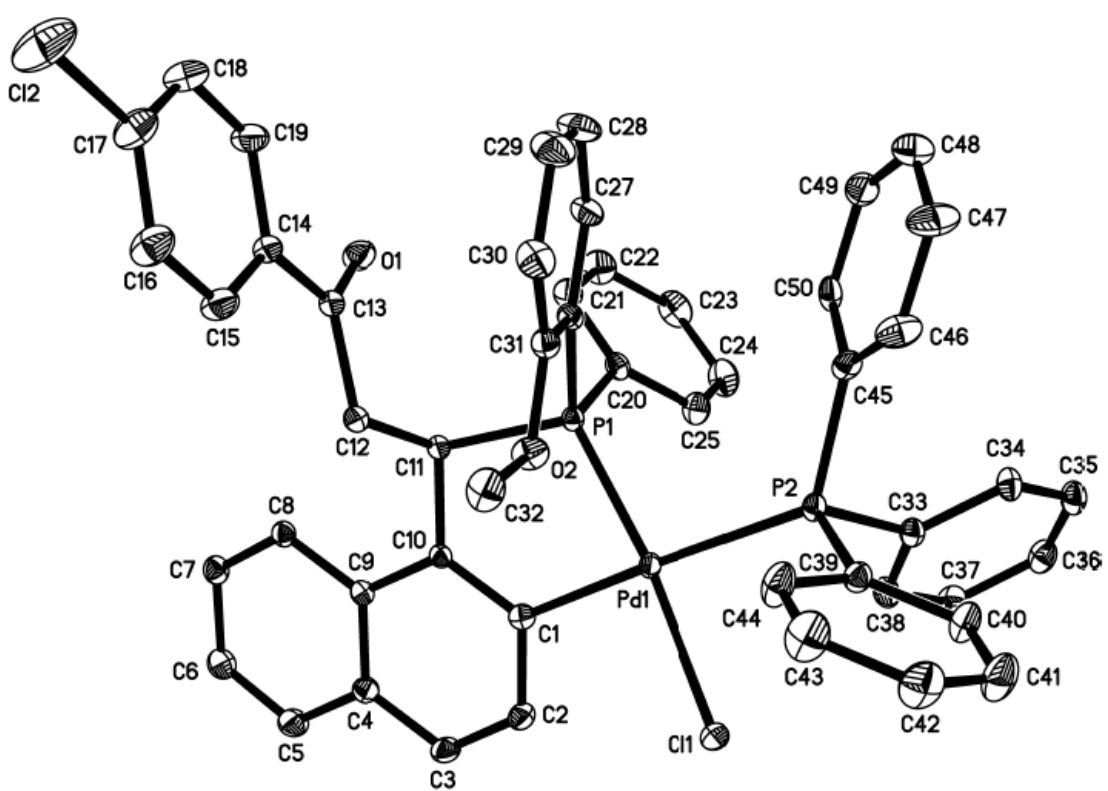

Figure 3.4 X-ray molecular structure of cis-rac-41 
Table 3.4 Selected bond lengths $(\AA)$ and angles $\left(^{\circ}\right)$ of $c i s-r a c-41$

\begin{tabular}{llll}
\hline $\mathrm{Pd}(1)-\mathrm{C}(1)$ & $2.0654(12)$ & $\mathrm{Pd}(1)-\mathrm{P}(1)$ & $2.2058(4)$ \\
$\mathrm{Pd}(1)-\mathrm{Cl}(1)$ & $2.3705(4)$ & $\mathrm{Pd}(1)-\mathrm{P}(2)$ & $2.3876(4)$ \\
$\mathrm{C}(11)-\mathrm{P}(1)$ & $1.8594(12)$ & $\mathrm{C}(20)-\mathrm{P}(1)$ & $1.8202(12)$ \\
$\mathrm{C}(26)-\mathrm{P}(1)$ & $1.8146(12)$ & $\mathrm{C}(10)-\mathrm{C}(11)$ & $1.5041(16)$ \\
$\mathrm{C}(1)-\mathrm{C}(10)$ & $1.3894(16)$ & $\mathrm{C}(11)-\mathrm{C}(12)$ & $1.5401(16)$ \\
$\mathrm{C}(12)-\mathrm{C}(13)$ & $1.5196(17)$ & $\mathrm{C}(13)-\mathrm{O}(1)$ & $1.2225(16)$ \\
$\mathrm{C}(13)-\mathrm{C}(14)$ & $1.4895(18)$ & $\mathrm{C}(33)-\mathrm{P}(2)$ & $1.8229(12)$ \\
$\mathrm{C}(39)-\mathrm{P}(2)$ & $1.8147(13)$ & $\mathrm{C}(45)-\mathrm{P}(2)$ & $1.860(3)$ \\
& & & \\
$\mathrm{C}(1)-\mathrm{Pd}(1)-\mathrm{P}(1)$ & $80.00(4)$ & $\mathrm{C}(1)-\mathrm{Pd}(1)-\mathrm{Cl}(1)$ & $94.13(4)$ \\
$\mathrm{P}(1)-\mathrm{Pd}(1)-\mathrm{Cl}(1)$ & $173.404(12)$ & $\mathrm{C}(1)-\mathrm{Pd}(1)-\mathrm{P}(2)$ & $174.11(3)$ \\
$\mathrm{P}(1)-\mathrm{Pd}(1)-\mathrm{P}(2)$ & $101.489(14)$ & $\mathrm{Cl}(1)-\mathrm{Pd}(1)-\mathrm{P}(2)$ & $84.652(14)$ \\
$\mathrm{C}(10)-\mathrm{C}(1)-\mathrm{Pd}(1)$ & $123.23(9)$ & $\mathrm{C}(1)-\mathrm{C}(10)-\mathrm{C}(11)$ & $119.69(10)$ \\
$\mathrm{C}(10)-\mathrm{C}(11)-\mathrm{P}(1)$ & $104.27(8)$ & $\mathrm{C}(11)-\mathrm{P}(1)-\mathrm{Pd}(1)$ & $107.92(4)$ \\
$\mathrm{C}(10)-\mathrm{C}(11)-\mathrm{C}(12)$ & $115.14(10)$ & $\mathrm{C}(12)-\mathrm{C}(11)-\mathrm{P}(1)$ & $114.59(8)$ \\
$\mathrm{C}(13)-\mathrm{C}(12)-\mathrm{C}(11)$ & $111.84(10)$ & $\mathrm{O}(1)-\mathrm{C}(13)-\mathrm{C}(14)$ & $119.99(11)$ \\
$\mathrm{O}(1)-\mathrm{C}(13)-\mathrm{C}(12)$ & $120.16(11)$ & $\mathrm{C}(14)-\mathrm{C}(13)-\mathrm{C}(12)$ & $119.81(11)$ \\
$\mathrm{C}(39)-\mathrm{P}(2)-\mathrm{Pd}(1)$ & $112.09(4)$ & $\mathrm{C}(33)-\mathrm{P}(2)-\mathrm{Pd}(1)$ & $110.20(4)$ \\
$\mathrm{C}(45)-\mathrm{P}(2)-\mathrm{Pd}(1)$ & $124.87(13)$ & & \\
\hline
\end{tabular}

The crystal structure diagram showed the minor isomer cis-rac-39. The diagram also confirmed the formation of a 5-membered ring structure. However, the stereoconfiguration of the compound is indeterminate. No optical activity was observed when measured, suggesting that a racemic compound was obtained. Therefore, a different synthetic strategy had to be devised in order to obtain an optically active isomer.

\subsubsection{Coordination to 1 and cyclopalladation of 37}

The free phosphines 37 from entry 2 were coordinated to achiral benzylamine dimer $\mathbf{1}$, forming two distereomeric pairs of enantiomers. The two distereomeric pairs were separated by column chromatography (Scheme 3.14). 


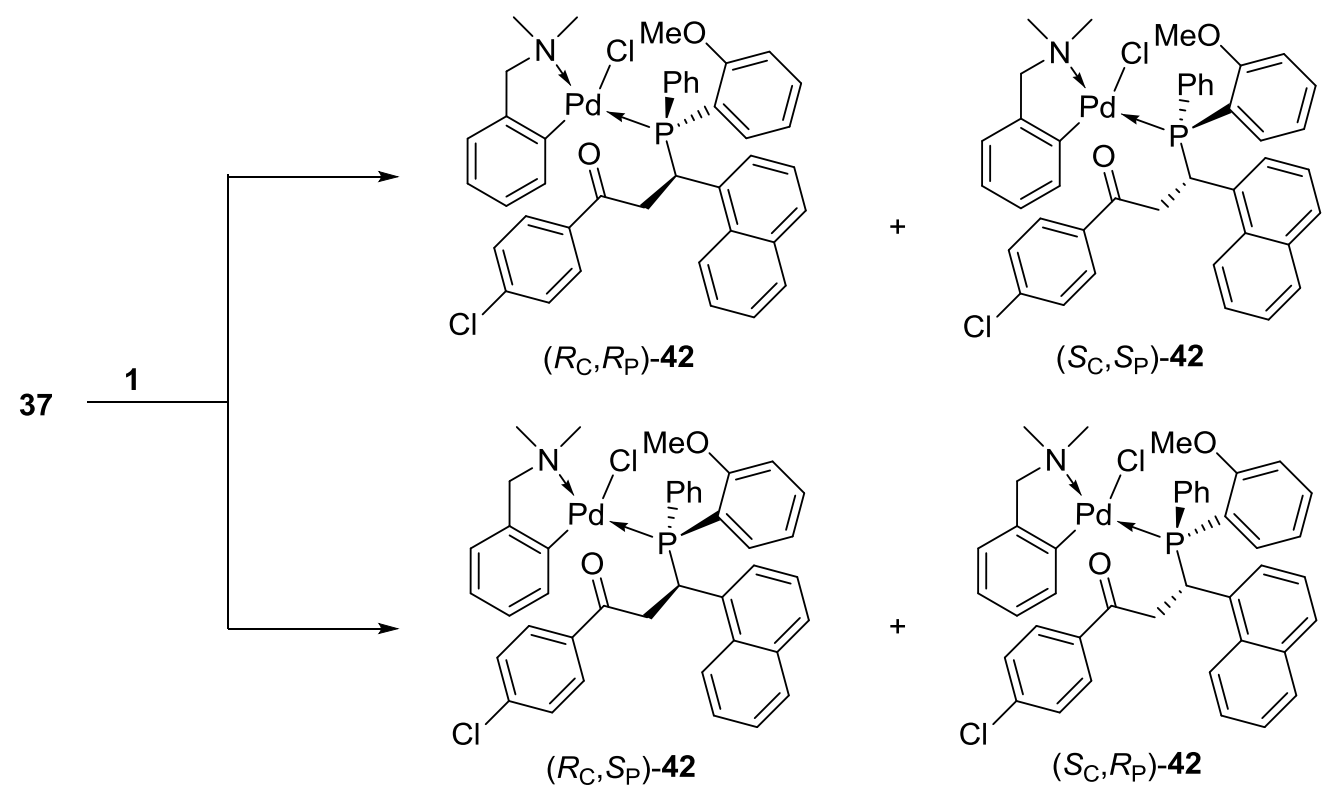

Scheme 3.14

The major product pair is $\left(R_{\mathrm{C}}, R_{\mathrm{P}}\right) \mathbf{- 4 2}$ and $\left(S_{\mathrm{C}}, S_{\mathrm{P}}\right)-\mathbf{4 2}$, with ${ }^{31} \mathrm{P}\left\{{ }^{1} \mathrm{H}\right\} \mathrm{NMR}$ $\left(202 \mathrm{MHz}, \mathrm{CDCl}_{3}\right)$ showing a single peak at $\delta 60.6$.

The benzylamine auxiliary was removed from $\left(R_{\mathrm{C}}, R_{\mathrm{P}}\right)-\mathbf{4 2}$ and $\left(S_{\mathrm{C}}, S_{\mathrm{P}}\right)-\mathbf{4 2}$, and the resulting dimer mixture 39 was ortho-palladated by reflux with ethanol and sodium acetate trihydrate to form the dichloro-bridged dimer mixture $\mathbf{4 0}$ (Scheme 3.15).

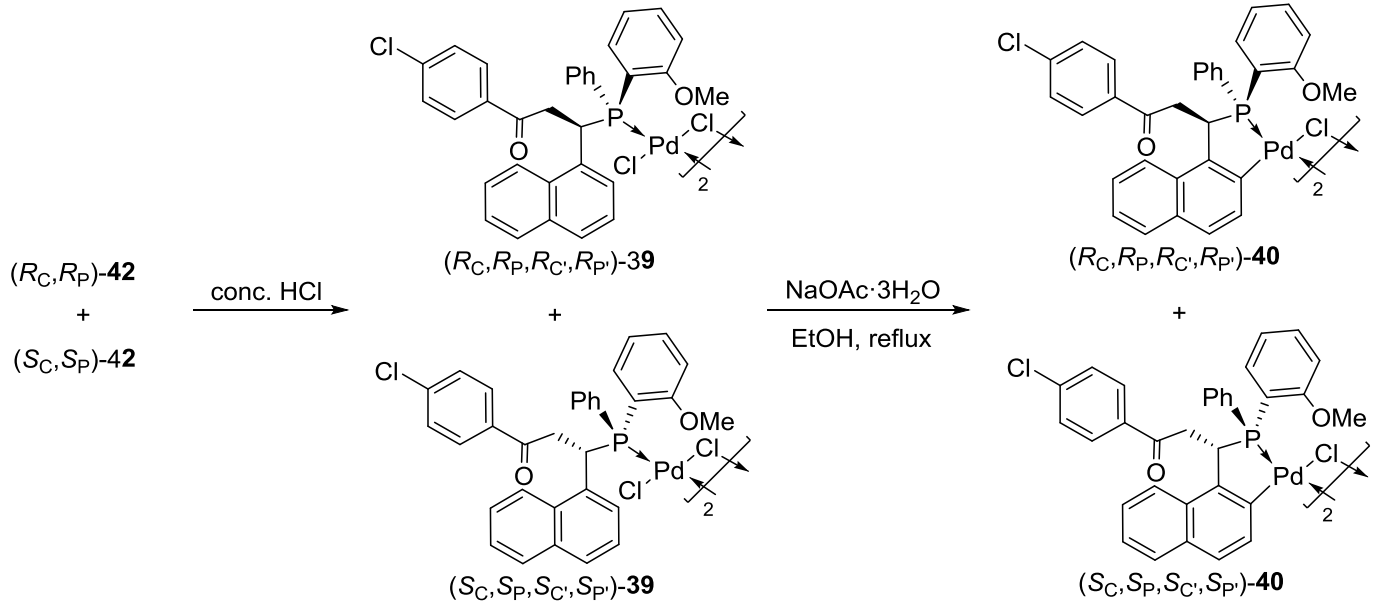

Scheme 3.15 
The racemic dimer was resolved by coordinating with $(S)$-proline and fractional crystallization (Scheme 3.16).
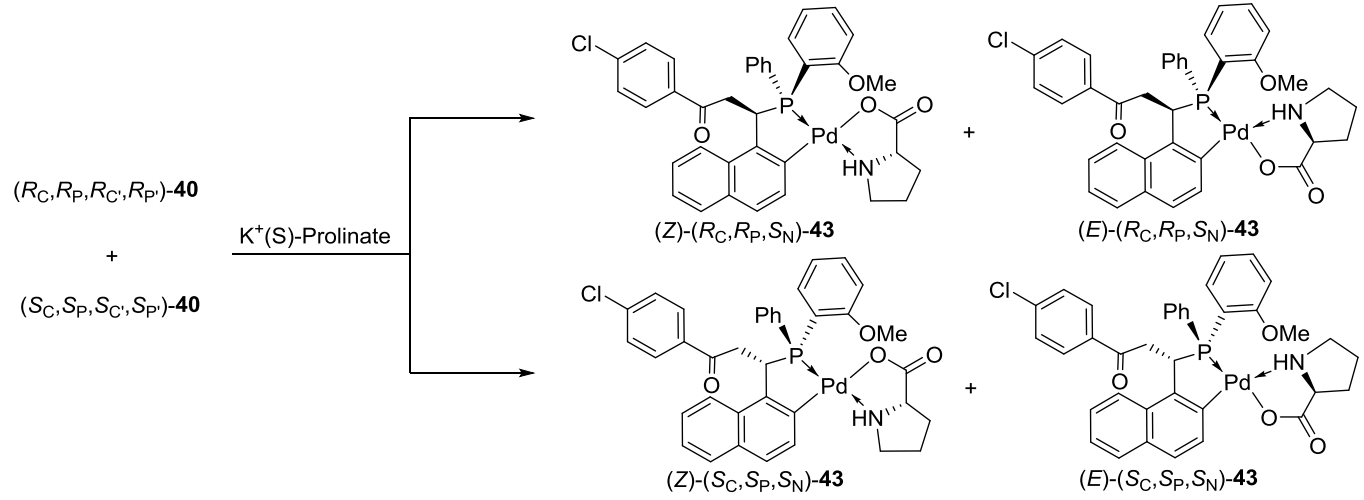

Scheme 3.16

The products $(Z) /(E)-\left(S_{\mathrm{C}}, S_{\mathrm{P}}, S_{\mathrm{N}}\right)-\mathbf{4 3}$ were successfully crystallized as white crystals and X-ray analysis was performed (Figure 3.5).

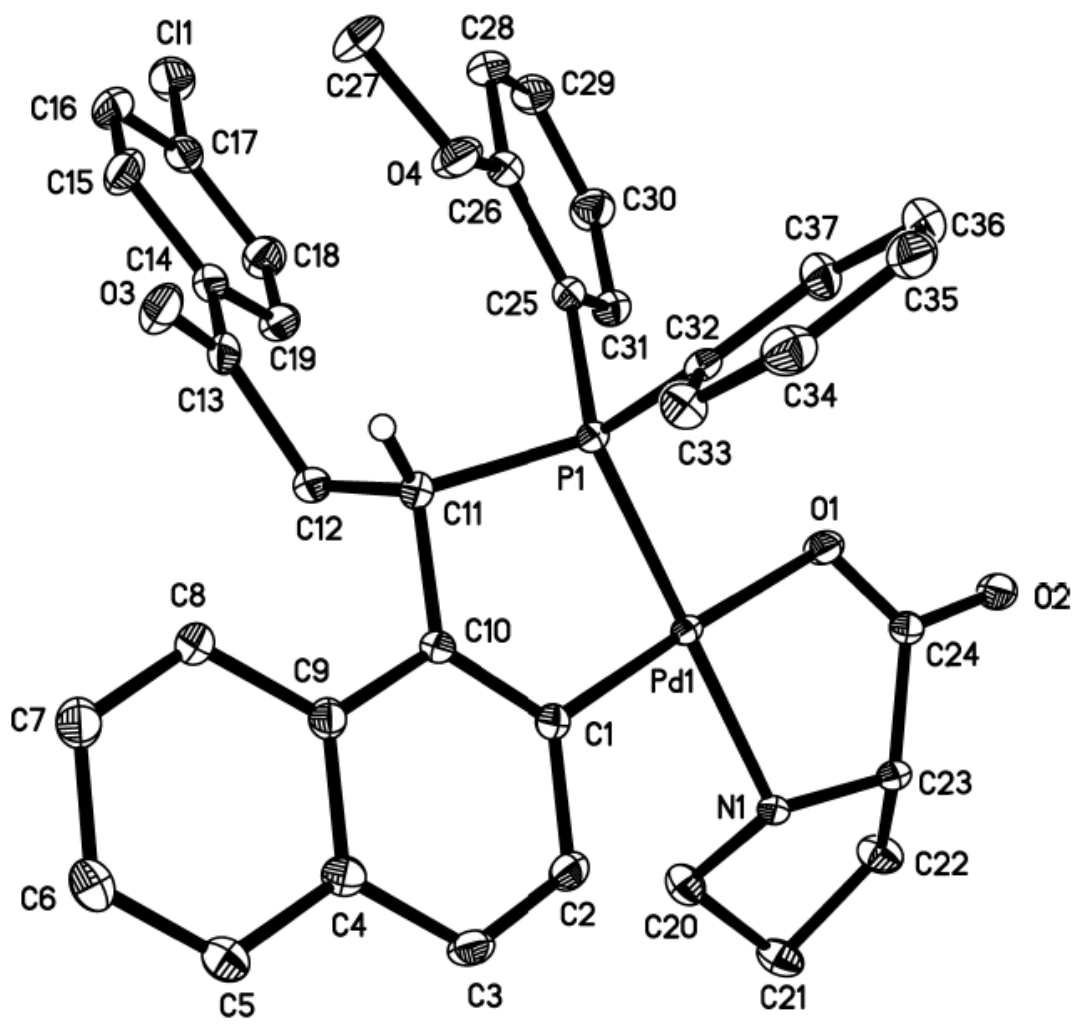

Figure 3.5 X-ray molecular structure of $(Z)-\left(S_{C}, S_{P}, S_{N}\right)-43$ 
Table 3.5 Selected bond lengths $(\AA)$ and angles $\left({ }^{\circ}\right)$ of $(Z)-\left(S_{\mathrm{C}}, S_{\mathrm{P}}, S_{\mathrm{N}}\right)-43$

\begin{tabular}{llll}
\hline $\mathrm{Pd}(1)-\mathrm{C}(1)$ & $2.014(3)$ & $\mathrm{Pd}(1)-\mathrm{O}(1)$ & $2.0909(18)$ \\
$\mathrm{Pd}(1)-\mathrm{N}(1)$ & $2.110(2)$ & $\mathrm{Pd}(1)-\mathrm{P}(1)$ & $2.2108(7)$ \\
$\mathrm{C}(11)-\mathrm{P}(1)$ & $1.840(3)$ & $\mathrm{C}(25)-\mathrm{P}(1)$ & $1.810(3)$ \\
$\mathrm{C}(32)-\mathrm{P}(1)$ & $1.814(3)$ & $\mathrm{C}(1)-\mathrm{C}(10)$ & $1.387(3)$ \\
$\mathrm{C}(10)-\mathrm{C}(11)$ & $1.519(3)$ & $\mathrm{C}(11)-\mathrm{C}(12)$ & $1.551(4)$ \\
$\mathrm{C}(12)-\mathrm{C}(13)$ & $1.521(4)$ & $\mathrm{C}(13)-\mathrm{O}(3)$ & $1.216(4)$ \\
$\mathrm{C}(13)-\mathrm{C}(14)$ & $1.493(4)$ & & \\
& & & \\
$\mathrm{C}(1)-\mathrm{Pd}(1)-\mathrm{O}(1)$ & $177.15(9)$ & $\mathrm{C}(1)-\mathrm{Pd}(1)-\mathrm{N}(1)$ & $97.60(9)$ \\
$\mathrm{O}(1)-\mathrm{Pd}(1)-\mathrm{N}(1)$ & $80.59(8)$ & $\mathrm{C}(1)-\mathrm{Pd}(1)-\mathrm{P}(1)$ & $80.91(7)$ \\
$\mathrm{O}(1)-\mathrm{Pd}(1)-\mathrm{P}(1)$ & $100.84(5)$ & $\mathrm{N}(1)-\mathrm{Pd}(1)-\mathrm{P}(1)$ & $177.93(6)$ \\
$\mathrm{C}(10)-\mathrm{C}(1)-\mathrm{Pd}(1)$ & $122.21(19)$ & $\mathrm{C}(1)-\mathrm{C}(10)-\mathrm{C}(11)$ & $119.0(2)$ \\
$\mathrm{C}(10)-\mathrm{C}(11)-\mathrm{P}(1)$ & $103.71(16)$ & $\mathrm{C}(11)-\mathrm{P}(1)-\mathrm{Pd}(1)$ & $104.85(8)$ \\
$\mathrm{C}(10)-\mathrm{C}(11)-\mathrm{C}(12)$ & $110.1(2)$ & $\mathrm{C}(12)-\mathrm{C}(11)-\mathrm{P}(1)$ & $111.04(18)$ \\
$\mathrm{C}(13)-\mathrm{C}(12)-\mathrm{C}(11)$ & $114.1(2)$ & $\mathrm{O}(3)-\mathrm{C}(13)-\mathrm{C}(14)$ & $120.4(2)$ \\
$\mathrm{O}(3)-\mathrm{C}(13)-\mathrm{C}(12)$ & $118.7(3)$ & $\mathrm{C}(14)-\mathrm{C}(13)-\mathrm{C}(12)$ & $120.9(2)$ \\
$\mathrm{N}(1)-\mathrm{C}(23)-\mathrm{C}(24)$ & $112.5(2)$ & $\mathrm{O}(1)-\mathrm{C}(24)-\mathrm{C}(23)$ & $118.5(2)$ \\
$\mathrm{C}(23)-\mathrm{N}(1)-\mathrm{Pd}(1)$ & $110.42(15)$ & $\mathrm{C}(24)-\mathrm{O}(1)-\mathrm{Pd}(1)$ & $116.15(16)$ \\
$\mathrm{C}(24)-\mathrm{C}(23)-\mathrm{C}(22)$ & $113.5(2)$ & $\mathrm{N}(1)-\mathrm{C}(20)-\mathrm{C}(21)$ & $103.9(2)$ \\
\hline
\end{tabular}

The X-ray study gave the structure of $(E)-\left(S_{\mathrm{C}}, S_{\mathrm{P}}, S_{\mathrm{N}}\right)-\mathbf{4 3}$, which shows the $S$ configuration at the $\mathrm{C}(11)$ chiral centre and $S$ configuration at the $\mathrm{P}(1)$ chiral centre.

The dichloro-bridge dimer $\left(S_{\mathrm{C}}, S_{\mathrm{P}}, S_{\mathrm{C}^{\prime}}, S_{\mathrm{P}^{\prime}}\right)-\mathbf{4 0}$ can be obtained through the removal of the $(\mathrm{S})$-proline auxiliary by treating $(Z) /(E)-\left(S_{\mathrm{C}}, S_{\mathrm{P}}, S_{\mathrm{N}}\right)-\mathbf{4 3}$ with $1 \mathrm{M}$ hydrochloric acid (Scheme 3.17).

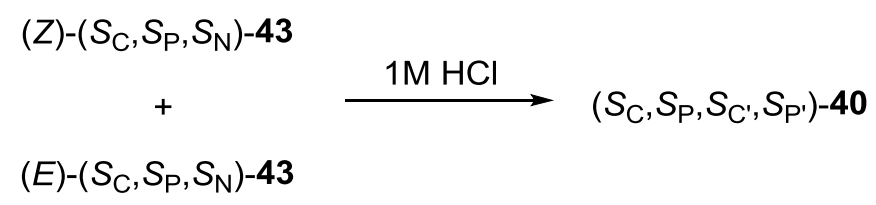

Scheme 3.17 
The other isomers $(Z) /(E)-\left(R_{\mathrm{C}}, R_{\mathrm{P}}, S_{\mathrm{N}}\right)-\mathbf{4 3}$ were crystallized as very thin white crystals, but not suitable for X-ray analysis. Likewise, $(Z) /(E)-\left(R_{\mathrm{C}}, R_{\mathrm{P}}, S_{\mathrm{N}}\right)-$ 43 can be treated with $1 \mathrm{M}$ hydrochloric acid to give the dichloro-bridged dimer

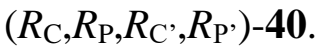

\subsubsection{Coordination of $\left(S_{\mathrm{C}}, S_{\mathrm{P}}, S_{\mathrm{C},}, S_{\mathrm{P}},\right)-40$ with triphenylphosphine and} dppe

$\left(S_{\mathrm{C}}, S_{\mathrm{P}}, S_{\left.\mathrm{C}^{\prime}, S_{\mathrm{P}},\right)-\mathbf{4 0}}\right.$ was coordinated with triphenylphosphine (Scheme 3.18) and dppe (Scheme 3.19) to form $\left(S_{\mathrm{C}}, S_{\mathrm{P}}\right)-\mathbf{4 1}$ and $\left(S_{\mathrm{C}}, S_{\mathrm{P}}\right)-\mathbf{4 4}$ respectively, however no crystal suitable for X-ray analysis was obtained.

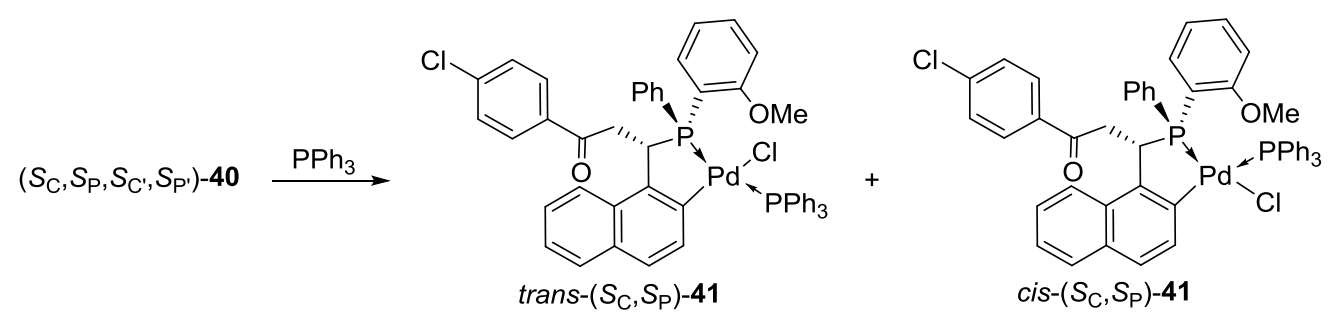

Scheme 3.18

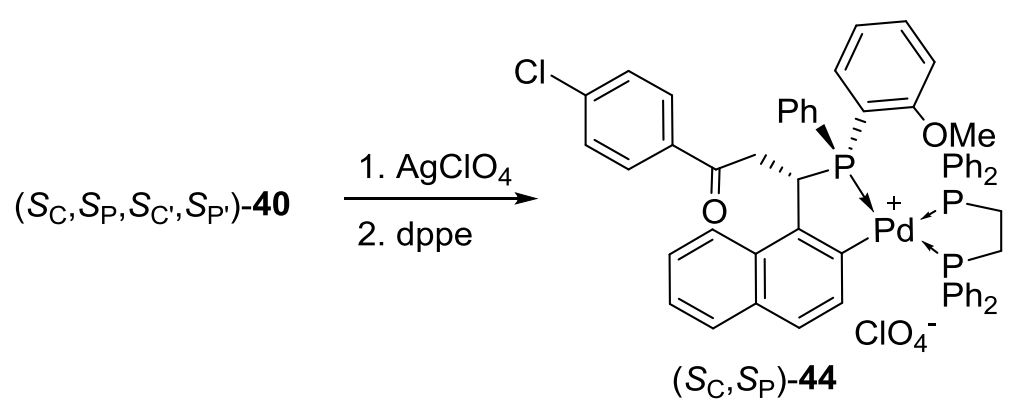

Scheme 3.19

\subsection{Conclusion}

The catalytic asymmetric hydrophosphination reaction of a 1-naphthylbased enone, (E)-1-(4-chlorophenyl)-3-(1-naphthyl)prop-2-en-1-one, 28 with diphenylphosphine was successfully performed. The stereoselectivity of the 
reaction could be improved by optimizing the reaction conditions. The enantioenriched free phosphine was coordinated to the $(R)-\mathbf{4}$ template for purification. The ortho-palladation of $(R, S)$-30 proceeded to form the chlorobridge dimer complex $(S, S)-32$, however efforts to obtain crystals suitable for X-ray analysis had been unsuccessful.

The synthetic method was extended to form a CP-palladacycle containing both a $\mathrm{C}$ chiral centre and a $\mathrm{P}$ chiral centre. The catalytic asymmetric hydrophosphination reaction of the 1-naphthyl-based enone $\mathbf{2 8}$ was repeated with a racemic secondary phosphine $o$-anisylphenylphosphine, which proceeded with 3:1 diastereoselectivity. Coordination to $(R)-\mathbf{4}$ failed to separate the stereoisomers properly, and the subsequent ortho-palladation resulted in a racemic product. An alternative method was used to resolve the issue. The achiral benzylamine template $\mathbf{1}$ was used to separate the two pairs of diastereomers, followed by ortho-palladation and optical resolution of the chloro-bridged dimer complex $\mathbf{4 0}$ by $(S)$-proline. The structure of the cyclopalladated ring and the absolute configuration at the chiral centres were confirmed by the X-ray crystal structure analysis of $(Z)-\left(S_{\mathrm{C}}, S_{\mathrm{P}}, S_{\mathrm{N}}\right)-\mathbf{4 3}$. The catalytic properties of the newly generated phosphapalladacycles remain to be studied.

\subsection{Experimental}

Reactions involving air-sensitive materials were performed under a positive pressure of nitrogen. NMR spectra were recorded on Bruker Avance 300, 400 and 500 spectrometers. ${ }^{1} \mathrm{H}$ and ${ }^{31} \mathrm{P}\left\{{ }^{1} \mathrm{H}\right\}$ NMR chemical shifts were referenced relative to $\mathrm{SiMe}_{4}$ and $\mathrm{H}_{3} \mathrm{PO}_{4}$ respectively. Melting points were 
determined on SRS-Optimelt MPA-100 apparatus and were uncorrected. Optical rotations were measured on the specified solution in a $0.1 \mathrm{dm}$ cell at $25^{\circ} \mathrm{C}$ with Atago AP-300 Automatic Polarimeter. Elemental Analyses and single crystal X-ray diffraction studies were performed by the Elemental Analysis Laboratory and X-ray Diffraction Laboratory, respectively, of the Division of Chemistry and Biological Chemistry at Nanyang Technological University. The starting materials, diphenylphosphine, ${ }^{39}$ racemic $o$ anisylphenylphosphine, ${ }^{42} \quad(R, R)$-di- $\mu$-chlorobis $\{1-[1-(N, N-$ dimethylamino)ethyl]naphthyl- $C, N\}$ dipalladium(II), ${ }^{26} \quad(R)-\mathbf{4}$, bis(acetonitrile) $\{(R)-1-[1-(N, N$-dimethylamino)ethyl]naphthyl-

$C, N\}$ palladium(II) perchlorate, $^{28} \quad(R)-\mathbf{5} \quad$ and $\quad$ bis(acetonitrile) $\{(S)-1-[1-$ (diphenylphosphino)ethyl]naphthyl-C,P palladium(II) perchlorate, ${ }^{31}(S)$-7 were prepared according to literature procedures.

\section{(E)-1-(4-Chlorophenyl)-3-(1-naphthyl)prop-2-en-1-one, 28.}

1-Naphthaldehyde (1.5 g, $1.3 \mathrm{~mL}, 9.6 \mathrm{mmol})$ and 4'-chloroacetophenone (1.48 g, $1.25 \mathrm{~mL}, 9.6 \mathrm{mmol})$ were dissolved in methanol (20 mL). Sodium hydroxide $(0.038 \mathrm{~g}, 0.96 \mathrm{mmol})$ in water $(10 \mathrm{~mL})$ was added. The mixture was stirred and heated to reflux overnight. The solvent was removed under reduced pressure. The product mixture was redissolved in dichloromethane $(10 \mathrm{~mL})$, washed with water (50 $\mathrm{mL}$ x 2) and dried with anhydrous $\mathrm{MgSO}_{4}$. The solvent was removed under reduced pressure and the product was purified by silica gel chromatography to give a yellow solid $(2.23 \mathrm{~g}, 79 \%)$. mp $86-88{ }^{\circ} \mathrm{C} ;{ }^{1} \mathrm{H}$ NMR (500 MHz, $\left.\mathrm{CDCl}_{3}\right) \delta$ 7.49-7.61 (m, 6H, aromatic), 7.89-7.95 (m, 3H, aromatic), 8.01-8.03 (m, 2H, aromatic), $8.25(\mathrm{~d}, 1 \mathrm{H}, J=8.3 \mathrm{~Hz}), 8.68(\mathrm{~d}, 1 \mathrm{H}, J=15.4 \mathrm{~Hz})$. 
[3-(4-Chlorophenyl)-1-(1-naphthyl)propan-3-onyl]diphenylphosphine， 29.

To a solution of diphenylphosphine $(0.066 \mathrm{~g}, 0.35 \mathrm{mmol})$ in dichloromethane (5 $\mathrm{mL}),(R)-5(0.034 \mathrm{~g}, 0.07 \mathrm{mmol}, 20 \mathrm{~mol} \%)$ was added. The solution was stirred at r.t. for $5 \mathrm{~min}$ and then cooled to $-80{ }^{\circ} \mathrm{C}$. Subsequently, the enone $28(0.103 \mathrm{~g}$, $0.35 \mathrm{mmol})$ was added. $\mathrm{Et}_{3} \mathrm{~N}(0.035 \mathrm{~g}, 0.35 \mathrm{mmol})$ in DCM $(1 \mathrm{~mL})$ was added dropwise. The solution was subsequently stirred at $-80{ }^{\circ} \mathrm{C}$ and the reaction was monitored by ${ }^{31} \mathrm{P}\left\{{ }^{1} \mathrm{H}\right\}$ NMR. The reaction was found to be completed at $2 \mathrm{~h}$. The product was not isolated and directly used in further reactions. NMR calculated yield: 71\%; ${ }^{31} \mathrm{P}\left\{{ }^{1} \mathrm{H}\right\} \mathrm{NMR}\left(202 \mathrm{MHz}, \mathrm{CDCl}_{3}\right) \delta 2.0(\mathrm{~s})$.

Coordination of 29 to $(R)-4$. Separation of chloro\{ $(R)-1-[1-(N, N-$ dimethylamino)ethyl]naphthyl- $C, N\}\{(R)-[3-(4-c h l o r o p h e n y l)-1-(1-$ naphthyl)propan-3-onyl]diphenylphosphine\}palladium(II), $(R, R)-30$ and chloro\{(R)-1-[1-(N,N-dimethylamino)ethyl]naphthyl-C,N\}\{(S)-[3-(4chlorophenyl)-1-(1-naphthyl)propan-3onyl]diphenylphosphine\}palladium(II), $(\boldsymbol{R}, S)-30$. $(R)-4(0.12 \mathrm{~g}, 0.175 \mathrm{mmol}$, 0.5 equiv. of phosphine) in dichloromethane $(5 \mathrm{~mL})$ was added to free phosphine 29 and the mixture was stirred for $30 \mathrm{~min}$. The solvent was removed under reduced pressure to give a yellow solid; ${ }^{31} \mathrm{P}\left\{{ }^{1} \mathrm{H}\right\} \mathrm{NMR}\left(202 \mathrm{MHz}, \mathrm{CDCl}_{3}\right)$ $\delta 47.9$ (s) and $\delta 50.9$ (s) in $1: 4.9$ ratio. The combined product was separated and purified by silica gel column chromatography using hexanes/dichloromethane/acetone $(3: 1: 0.2, \mathrm{v} / \mathrm{v})$ as eluant to give a yellow solid. 
Chloro\{(R)-1-[1-(N,N-dimethylamino)ethyl]naphthyl- $C, N\}\{(R)-[3-(4-$

chlorophenyl)-1-(1-naphthyl)propan-3-

onyl]diphenylphosphine \}palladium(II), $\quad(\boldsymbol{R}, \boldsymbol{R})-30$. The product was recrystallized from dichloromethane-diethyl ether as yellow crystals $(0.030 \mathrm{~g}$, 61\%). mp 201-203 ${ }^{\circ} \mathrm{C}(\mathrm{dec}) ;{ }^{31} \mathrm{P}\left\{{ }^{1} \mathrm{H}\right\} \mathrm{NMR}\left(202 \mathrm{MHz}, \mathrm{CDCl}_{3}\right) \delta 47.9$ (s).

Chloro\{(R)-1-[1-(N,N-dimethylamino)ethyl]naphthyl-C,N\}\{(S)-[3-(4chlorophenyl)-1-(1-naphthyl)propan-3-

onyl]diphenylphosphine $\}$ palladium(II), $\quad(\boldsymbol{R}, \boldsymbol{S})-30$. The product was recrystallized from dichloromethane-diethyl ether as yellow crystals $(0.16 \mathrm{~g}$, 66\%). mp 212-215 ${ }^{\circ} \mathrm{C} ;{ }^{31} \mathrm{P}\left\{{ }^{1} \mathrm{H}\right\} \mathrm{NMR}\left(202 \mathrm{MHz}, \mathrm{CDCl}_{3}\right) \delta 50.9$ (s).

\section{Dichlorodi- $\mu$-chlorobis\{(S)-[3-(4-chlorophenyl)-1-(1-naphthyl)propan-3-} onyl]diphenylphosphine $\}$ dipalladium(II), $(\boldsymbol{S}, \boldsymbol{S})$-31. Conc. $\mathrm{HCl}(1 \mathrm{~mL})$ was added to a solution of $(R, S)-30(0.4 \mathrm{~g}, 0.49 \mathrm{mmol})$ in dichloromethane $(5 \mathrm{~mL})$. The yellow solution turned orange upon adding the conc. $\mathrm{HCl}$. The solution was stirred for an hour, and then quenched by water $(50 \mathrm{~mL})$. The organic phase was separated, further washed with water $(2 \times 50 \mathrm{~mL})$, dried with anhydrous $\mathrm{MgSO}_{4}$ and filtered. The solvent was removed under reduced pressure to give an orange solid $(0.32 \mathrm{~g}, 98 \%) .{ }^{31} \mathrm{P}\left\{{ }^{1} \mathrm{H}\right\}$ NMR $(202 \mathrm{MHz}$, $\left.\mathrm{CDCl}_{3}\right) \delta 40.5(\mathrm{~s})$.

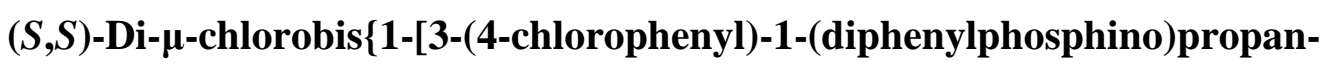
3-onyl]naphthyl-C,P \}dipalladium(II), $(\boldsymbol{S}, \boldsymbol{S})$-32. Product $(S, S)$-31 (0.32 g, 0.24 $\mathrm{mmol})$ was suspended in ethanol $(50 \mathrm{~mL})$ and sodium acetate trihydrate $(1.8 \mathrm{~g})$ was added. The mixture was heated to reflux for $2 \mathrm{~h}$. After removing the solvent under reduced pressure, the crude product was dissolved in 
dichloromethane $(10 \mathrm{~mL})$, washed with water $(50 \mathrm{~mL}$ x 2$)$ and dried with anhydrous $\mathrm{MgSO}_{4}$. The crude product was then purified by silica gel column chromatography using hexanes/dichloromethane/acetone $(3: 1: 0.2, \mathrm{v} / \mathrm{v})$ as eluant to give a yellow solid $(0.18 \mathrm{~g}, 60 \%) .{ }^{31} \mathrm{P}\left\{{ }^{1} \mathrm{H}\right\} \mathrm{NMR}\left(121 \mathrm{MHz}, \mathrm{CDCl}_{3}\right) \delta 64.0$ (s), $64.2(\mathrm{~s})$.

Coordination of 29 to 1 . Formation of chloro $\{[(N, N-$ dimethylamino)methyl]phenyl- $C, N\}\{[3-(4-c h l o r o p h e n y l)-1-(1-$ naphthyl)propan-3-onyl]diphenylphosphine\}palladium(II), 33. The free phosphine 29 was prepared from diphenylphosphine $(0.11 \mathrm{~g}, 0.59 \mathrm{mmol})$ and enone 28 (0.19 g, $0.65 \mathrm{mmol}, 1.1$ equiv.) in the presence of catalyst $(R)-5$ $(0.057 \mathrm{~g}, 0.12 \mathrm{mmol}, 5 \mathrm{~mol} \%)$ and $\mathrm{Et}_{3} \mathrm{~N}(0.043 \mathrm{~g}, 0.59 \mathrm{mmol})$ at $-80{ }^{\circ} \mathrm{C} .1(0.18$ g, $0.32 \mathrm{mmol}, 0.55$ equiv. $)$ in dichloromethane $(5 \mathrm{~mL})$ was added to free phosphine 29 and the mixture was stirred for $30 \mathrm{~min}$. The solvent was removed under reduced pressure. The combined product was separated and purified by silica gel column chromatography using hexanes/dichloromethane/acetone (5:1:0.5, v/v) as eluant to give a yellow solid $(0.35 \mathrm{~g}, 78 \%) .{ }^{31} \mathrm{P}\left\{{ }^{1} \mathrm{H}\right\}$ NMR $(202$ $\left.\mathrm{MHz}, \mathrm{CDCl}_{3}\right) \delta 52.9(\mathrm{~s})$

\section{Dichlorodi- $\mu$-chlorobis\{[3-(4-chlorophenyl)-1-(1-naphthyl)propan-3-}

onyl]diphenylphosphine \}dipalladium(II), 31. Conc. $\mathrm{HCl}(1 \mathrm{~mL})$ was added to a solution of $\mathbf{3 3}(0.35 \mathrm{~g}, 0.46 \mathrm{mmol})$ in dichloromethane $(5 \mathrm{~mL})$. The yellow solution turned orange upon adding the conc. $\mathrm{HCl}$. The solution was stirred for an hour, and then quenched by water $(50 \mathrm{~mL})$. The organic phase was separated, further washed with water $(2 \times 50 \mathrm{~mL})$, dried with anhydrous $\mathrm{MgSO}_{4}$ and filtered. The solvent was removed under reduced pressure to give an orange solid (0.32 g, 92\%). ${ }^{31} \mathrm{P}\left\{{ }^{1} \mathrm{H}\right\} \mathrm{NMR}\left(202 \mathrm{MHz}, \mathrm{CDCl}_{3}\right) \delta 43.7$ (s). 


\section{Di- $\mu$-chlorobis\{1-[3-(4-chlorophenyl)-1-(diphenylphosphino)propan-3-}

onyl]naphthyl- $\boldsymbol{C}, \boldsymbol{P}$ \}dipalladium(II), 32. Product $\mathbf{3 1}(0.32 \mathrm{~g}, 0.24 \mathrm{mmol})$ was dissolved in ethanol $(10 \mathrm{~mL})$ and sodium acetate trihydrate $(0.95 \mathrm{~g})$ was added. The mixture was heated to reflux for $2 \mathrm{~h}$. After removing the solvent under reduced pressure, the crude product was dissolved in dichloromethane $(10 \mathrm{~mL})$, washed with water $\left(50 \mathrm{~mL}\right.$ x 2) and dried with anhydrous $\mathrm{MgSO}_{4}$. The crude product was then purified by silica gel column chromatography to give a yellow solid (0.13 g, 43\%). ${ }^{31} \mathrm{P}\left\{{ }^{1} \mathrm{H}\right\}$ NMR (121 MHz, $\left.\mathrm{CDCl}_{3}\right) \delta 63.9$ (s), 64.0 (s), 64.2 (s), $64.3(\mathrm{~s})$.

[(S)-Prolinato]\{1-[3-(4-chlorophenyl)-1-(diphenylphosphino)propan-3onyl]naphthyl- $\boldsymbol{C , P}$ \}palladium(II), 34. The complex $32(0.13 \mathrm{~g}, 0.10 \mathrm{mmol})$ in dichloromethane $(5 \mathrm{~mL})$ was added to a solution of excess potassium $(S)$ prolinate $(\mathrm{KOH}$ and $(S)$-proline) in methanol $(5 \mathrm{~mL})$. The combined solution was stirred for $2 \mathrm{~h}$. The solvent was removed under reduced pressure, redissolved in dichloromethane, washed with water $(50 \mathrm{~mL}$ x 2) and dried with anhydrous $\mathrm{MgSO}_{4}$. The dichloromethane was removed under reduced pressure to give a white solid. ${ }^{31} \mathrm{P}\left\{{ }^{1} \mathrm{H}\right\} \mathrm{NMR}\left(202 \mathrm{MHz}, \mathrm{CDCl}_{3}\right) 4$ signals in ca. $4.9: 1$ : $1.8: 8.2$ ratio, $\delta 58.6(\mathrm{~s}), 60.1(\mathrm{~s}), 60.2(\mathrm{~s}), 61.3(\mathrm{~s})$

$[(S)$-Prolinato]\{(R)-1-[3-(4-chlorophenyl)-1-(diphenylphosphino)propan-3onyl]naphthyl-C,P $\}$ palladium(II), $\left(\boldsymbol{R}_{\mathrm{C}}, \boldsymbol{S}_{\mathrm{N}}\right)$-34. The product was crystallized from dichloromethane-diethyl ether as white crystals $(0.020 \mathrm{~g}, 80 \%)$. mp 118$120{ }^{\circ} \mathrm{C}(\mathrm{dec}) ;{ }^{31} \mathrm{P}\left\{{ }^{1} \mathrm{H}\right\} \mathrm{NMR}\left(202 \mathrm{MHz}, \mathrm{CDCl}_{3}\right) \delta 60.1$ (s), 60.2 (s).

[(S)-Prolinato]\{(S)-1-[3-(4-chlorophenyl)-1-(diphenylphosphino)propan-3onyl]naphthyl- $C, P$ \}palladium(II), $\left(S_{\mathrm{C}}, S_{\mathrm{N}}\right)-34$. The product was crystallized 
from dichloromethane-diethyl ether as white crystals $(0.10 \mathrm{~g}, 83 \%) .{ }^{31} \mathrm{P}\left\{{ }^{1} \mathrm{H}\right\}$ NMR (202 MHz, $\left.\mathrm{CDCl}_{3}\right) \delta 58.6(\mathrm{~s}), 61.2(\mathrm{~s})$.

\section{Chloro\{(S)-1-[3-(4-chlorophenyl)-1-(diphenylphosphino)propan-3-} onyl]naphthyl-C,P\}(triphenylphosphine)palladium(II),

(S)-35. Triphenylphosphine $(0.027 \mathrm{~g}, 0.10 \mathrm{mmol}, 2$ equiv. $)$ was added to $(S, S)-32$ $(0.064 \mathrm{~g}, 0.05 \mathrm{mmol})$ in dichloromethane $(5 \mathrm{~mL})$ and stirred for $30 \mathrm{~min}$. The solvent was removed under reduced pressure to give a yellow solid. The product cannot be induced to crystallize despite the use of a variety of solvents. ${ }^{31} \mathrm{P}\left\{{ }^{1} \mathrm{H}\right\}$ NMR $\left(202 \mathrm{MHz}, \mathrm{CDCl}_{3}\right) 4$ sets of signals in ca. $1.5: 1: 1: 1.5$ ratio, $\delta$ $17.0\left(\mathrm{~d},{ }^{2} J_{\mathrm{PP}}=26.3 \mathrm{~Hz}\right.$, coordinated $\mathrm{PPh}_{3}$ ligand of cis geometric isomer $), 25.5$ $\left(\mathrm{d},{ }^{2} J_{\mathrm{PP}}=423.2 \mathrm{~Hz}\right.$, coordinated $P \mathrm{Ph}_{3}$ ligand of trans geometric isomer), $53.1(\mathrm{~d}$, ${ }^{2} J_{\mathrm{PP}}=423.2 \mathrm{~Hz}$, phosphapalladacycle $P$ of trans geometric isomer), $63.6(\mathrm{~d}$, ${ }^{2} J_{\mathrm{PP}}=26.3 \mathrm{~Hz}$, phosphapalladacycle $P$ of cis geometric isomer).

\section{[1,2-Bis(diphenylphosphino)ethane-P,P']\{(S)-1-[3-(4-chlorophenyl)-1-}

\section{(diphenylphosphino)propan-3-onyl]naphthyl-C,P \}palladium(II)}

perchlorate, $(\boldsymbol{S})$-36. Silver(II) perchlorate $(0.1 \mathrm{~g}, 0.48 \mathrm{mmol}, 3$ equiv.) in water $(1 \mathrm{~mL})$ was added to $(S, S)-32(0.2 \mathrm{~g}, 0.16 \mathrm{mmol})$ in dichloromethane $(5 \mathrm{~mL})$ and stirred for 2 hours. The organic phase was washed with water $(50 \mathrm{~mL}$ x 2) and dried with anhydrous $\mathrm{MgSO}_{4} .1,2$-Bis(diphenylphosphino)ethane $(0.125 \mathrm{~g}$, $0.32 \mathrm{mmol}, 2$ equiv.) was added to the product and stirred for $30 \mathrm{~min}$. The solvent was removed under reduced pressure to give a yellow solid. The product cannot be induced to crystallize despite the use of a variety of solvents. ${ }^{31} \mathrm{P}\left\{{ }^{1} \mathrm{H}\right\}$ NMR $\left(162 \mathrm{MHz}, \mathrm{CDCl}_{3}\right) \delta 41.1\left(\mathrm{dd},{ }^{2} J_{\mathrm{P}(\text { trans })-\mathrm{P}(c i s)}=28.0 \mathrm{~Hz},{ }^{2} J_{\mathrm{P}-\mathrm{P}(\text { cis })}=\right.$ $24.1 \mathrm{~Hz}$, coordinated dppe ligand $P$ cis to phosphapalladacycle $\mathrm{P}), 49.6$ (dd, ${ }^{2} J_{\mathrm{P}-}$ $\mathrm{P}($ trans $)=343.5 \mathrm{~Hz},{ }^{2} J_{\mathrm{P}(\text { trans })-\mathrm{P}(\text { cis })}=28.0 \mathrm{~Hz}$, coordinated dppe ligand $P$ trans to 
phosphapalladacycle P), $56.2\left(\mathrm{dd},{ }^{2} J_{\mathrm{P}-\mathrm{P}(\text { trans })}=343.5 \mathrm{~Hz},{ }^{2} J_{\mathrm{P}-\mathrm{P}(\text { cis })}=24.1 \mathrm{~Hz}\right.$, phosphapalladacycle $P$ ).

\section{[3-(4-Chlorophenyl)-1-(1-naphthyl)propan-3-onyl](2-}

methoxyphenyl)phenylphosphine, 37. To a solution of $o$ anisylphenylphosphine $(0.12 \mathrm{~g}, 0.56 \mathrm{mmol})$ in chloroform $(5 \mathrm{~mL}),(R)-5(0.041$ g, $0.084 \mathrm{mmol}, 15 \mathrm{~mol} \%$ ) was added. The solution was stirred at r.t. for $5 \mathrm{~min}$ and then was cooled to $-80{ }^{\circ} \mathrm{C}$. Subsequently, the enone $28(0.18 \mathrm{~g}, 0.61 \mathrm{mmol}$, 1.1 equiv.) was added. $\mathrm{Et}_{3} \mathrm{~N}(0.57 \mathrm{~g}, 0.56 \mathrm{mmol})$ in chloroform $(1 \mathrm{~mL})$ was added dropwise. The solution was subsequently stirred at r.t. and the reaction was monitored by ${ }^{31} \mathrm{P}\left\{{ }^{1} \mathrm{H}\right\}$ NMR. The reaction was found to be completed after $2 \mathrm{~d}$. The product was not isolated and directly used in further reactions. NMR calculated conversion: 97\%, calculated yield: $81 \% ;{ }^{31} \mathrm{P}\left\{{ }^{1} \mathrm{H}\right\} \mathrm{NMR}(202 \mathrm{MHz}$, $\left.\mathrm{CDCl}_{3}\right) 2$ overlapping signals at $\delta-8.8,\left(202 \mathrm{MHz}, \mathrm{CD}_{2} \mathrm{Cl}_{2}\right) 2$ overlapping signals at $\delta-6.4,\left(202 \mathrm{MHz}, \mathrm{THF}-d_{8}\right) 2$ signals in ca. $1: 1.6$ ratio, $\delta-6.0(\mathrm{~s}),-$ 4.5 (s). (202 MHz, Acetone- $d_{6}$ ) 2 signals in ca. $1: 2$ ratio, $\delta-4.8$ (s), -3.6 (s).

\section{Chloro\{ $\{(R)-1-[1-(N, N$-dimethylamino)ethyl]naphthyl-C,N\}\{[3-(4-}

chlorophenyl)-1-(1-naphthyl)propan-3-onyl](2-

methoxyphenyl)phenylphosphine\}palladium(II), $(\boldsymbol{R})-38 .(R)-4(0.21 \mathrm{~g}, 0.31$ mmol, 0.55 equiv. to phosphine $)$ in dichloromethane $(5 \mathrm{~mL})$ was added to free phosphine 35 and the mixture was stirred for $30 \mathrm{~min}$. The solvent was removed under reduced pressure to give a yellow solid; ${ }^{31} \mathrm{P}\left\{{ }^{1} \mathrm{H}\right\} \mathrm{NMR}\left(202 \mathrm{MHz}, \mathrm{CDCl}_{3}\right)$ $\delta 55.7(\mathrm{~s}), 58.3$ (s) in ca. $1.33: 1$ ratio. The product was separated by silica gel column chromatography using hexanes/dichloromethane/acetone (5:1:0.5, v/v) as eluant to give $(R)-38 \mathbf{a}\left(0.20 \mathrm{~g}, 74 \% ;{ }^{31} \mathrm{P}\left\{{ }^{1} \mathrm{H}\right\}\right.$ NMR $\left(202 \mathrm{MHz}, \mathrm{CDCl}_{3}\right) \delta$ 
55.7) and $(R)-38 b\left(0.16 \mathrm{~g}, 79 \% ;{ }^{31} \mathrm{P}\left\{{ }^{1} \mathrm{H}\right\} \mathrm{NMR}\left(202 \mathrm{MHz}, \mathrm{CDCl}_{3}\right) \delta 58.3\right)$ as yellow solids.

\section{Dichlorodi- $\mu$-chlorobis\{[3-(4-chlorophenyl)-1-(1-naphthyl)propan-3-} onyl](2-methoxyphenyl)phenylphosphine\}dipalladium(II), 39. Conc. $\mathrm{HCl}$ (1 $\mathrm{mL})$ was added to a racemic mixture of $(R)-38 \mathrm{~b}(0.14 \mathrm{~g}, 0.17 \mathrm{mmol})$ in dichloromethane $(5 \mathrm{~mL})$. The yellow solution turned orange upon adding the conc. $\mathrm{HCl}$. The solution was stirred for an hour, and then quenched by water $(50 \mathrm{~mL})$. The organic phase was separated, further washed with water $(2 \times 50$ $\mathrm{mL}$ ), dried with anhydrous $\mathrm{MgSO}_{4}$ and filtered. The solvent was removed under reduced pressure to give an orange solid $(0.11 \mathrm{~g}, 98 \%) .{ }^{31} \mathrm{P}\left\{{ }^{1} \mathrm{H}\right\}$ NMR (202 $\left.\mathrm{MHz}, \mathrm{CDCl}_{3}\right) \delta 39.3(\mathrm{~s}), 39.7(\mathrm{~s}), 41.4(\mathrm{~s}), 41.9(\mathrm{~s})$.

\section{Di- $\mu$-chlorobis $\{[3-(4-c h l o r o p h e n y l)-1-(1-n a p h t h y l) p r o p a n-3-o n y l](2-$} methoxyphenyl)phenylphosphine $\}$ dipalladium(II), 40. Product 39 (0.11 g, $0.08 \mathrm{mmol})$ was dissolved in ethanol $(10 \mathrm{~mL})$ and sodium acetate trihydrate $(0.33 \mathrm{~g})$ was added. The mixture was heated to reflux for $2 \mathrm{~h}$. After removing the solvent under reduced pressure, the crude product was dissolved in dichloromethane $(10 \mathrm{~mL})$, washed with water $(50 \mathrm{~mL} \times 2)$ and dried with anhydrous $\mathrm{MgSO}_{4}$. The crude product was then purified by silica gel column chromatography using hexanes/dichloromethane/acetone $(5: 1: 0.5, \mathrm{v} / \mathrm{v})$ as eluant to give a yellow solid $(0.080 \mathrm{~g}, 77 \%) .{ }^{31} \mathrm{P}\left\{{ }^{1} \mathrm{H}\right\} \mathrm{NMR}\left(202 \mathrm{MHz}, \mathrm{CDCl}_{3}\right) \delta 57.1$ (s), $57.6(\mathrm{~s})$. 
methoxyphenyl)phenylphosphino)propan-3-onyl]naphthyl-

$\boldsymbol{C , P}$ (triphenylphosphine)palladium(II), 41. The dimer 40 (0.074 g, 0.057 $\mathrm{mmol})$ was dissolved in dichloromethane $(5 \mathrm{~mL})$. Triphenylphosphine $(0.03 \mathrm{~g}$, $0.11 \mathrm{mmol}, 2$ equiv.) was added and stirred for $30 \mathrm{~min}$. The solvent was removed under pressure to give product as yellow solid. Recrystallization from dichoromethane-hexane gives racemic yellow crystals $(0.090 \mathrm{~g}, 87 \%) .{ }^{31} \mathrm{P}\left\{{ }^{1} \mathrm{H}\right\}$ NMR $\left(202 \mathrm{MHz}, \mathrm{CDCl}_{3}\right) 4$ sets of signals in ca. $1: 1.6: 1.6: 1$ ratio, $\delta 17.6(\mathrm{~d}$, ${ }^{2} J_{\mathrm{PP}}=26.3 \mathrm{~Hz}$, coordinated $P \mathrm{Ph}_{3}$ ligand of cis geometric isomer), $25.5\left(\mathrm{~d},{ }^{2} J_{\mathrm{PP}}\right.$ $=427.2 \mathrm{~Hz}$, coordinated $\mathrm{PPh}_{3}$ ligand of trans geometric isomer), $49.5\left(\mathrm{~d},{ }^{2} J_{\mathrm{PP}}=\right.$ $427.2 \mathrm{~Hz}$, phosphapalladacycle $P$ of trans geometric isomer), 53.9 (d, ${ }^{2} J_{\mathrm{PP}}=$ $26.3 \mathrm{~Hz}$, phosphapalladacycle $P$ of $c$ is geometric isomer).

\section{Chloro $\{[(N, N$-dimethylamino)methyl]phenyl- $C, N\}\{[3-(4-c h l o r o p h e n y l)-1-$}

\section{(1-naphthyl)propan-3-onyl](2-}

methoxyphenyl)phenylphosphine\}palladium(II), 42. The free phosphine 37 was prepared from $o$-anisylphenylphosphine $(0.155 \mathrm{~g}, 0.72 \mathrm{mmol})$ and enone $28(0.23 \mathrm{~g}, 0.79 \mathrm{mmol}, 1.1$ equiv. $)$ in the presence of catalyst $(R)-5(0.052 \mathrm{~g}$, $0.11 \mathrm{mmol}, 15 \mathrm{~mol} \%)$ and $\mathrm{Et}_{3} \mathrm{~N}(0.073 \mathrm{~g}, 0.72 \mathrm{mmol})$ at r.t. for $4 \mathrm{~d}$. NMR calculated conversion: $99 \%$, calculated yield: $78 \% .1(0.22 \mathrm{~g}, 0.39 \mathrm{mmol}, 0.55$ equiv.) in dichloromethane $(5 \mathrm{~mL})$ was added to free phosphine 37 and the mixture was stirred for $30 \mathrm{~min}$. The solvent was removed under reduced pressure to give a yellow solid; ${ }^{31} \mathrm{P}\left\{{ }^{1} \mathrm{H}\right\} \mathrm{NMR}\left(202 \mathrm{MHz}, \mathrm{CDCl}_{3}\right) 2$ signals in ca. $1: 3$ ratio, $\delta 44.8(\mathrm{~s}), 60.6$ (s). The combined product was purified by silica gel column chromatography using hexanes/dichloromethane/acetone (5:1:0.5, v/v) as eluant to give a yellow solid. 
Racemic mixture of chloro $\{[(N, N$-dimethylamino $)$ methyl $]$ phenyl$C, N\}\left\{\left(R_{\mathrm{C}}, R_{\mathrm{P}}\right)\right.$-[3-(4-chlorophenyl)-1-(1-naphthyl)propan-3-onyl](2-

methoxyphenyl)phenylphosphine $\}$ palladium(II), $\quad\left(\boldsymbol{R}_{\mathrm{C}}, \boldsymbol{R}_{\mathrm{P}}\right)-42 \quad$ and chloro $\{[(N, N$-dimethylamino $)$ methyl $]$ phenyl- $C, N\}\left\{\left(S_{\mathrm{C}} S_{\mathrm{P}}\right)-[3-(4-\right.$

chlorophenyl)-1-(1-naphthyl)propan-3-onyl](2-

methoxyphenyl)phenylphosphine\}palladium(II), $\left(S_{\mathrm{C}}, S_{\mathrm{P}}\right)$-42. Separation by silica gel column chromatography using hexanes/dichloromethane/acetone (5:1:0.5, v/v) as eluant gave a yellow solid $(0.30 \mathrm{~g}, 71 \%) .{ }^{31} \mathrm{P}\left\{{ }^{1} \mathrm{H}\right\}$ NMR $(202$ $\left.\mathrm{MHz}, \mathrm{CDCl}_{3}\right) \delta 60.6(\mathrm{~s}),{ }^{31} \mathrm{P}\left\{{ }^{1} \mathrm{H}\right\} \mathrm{NMR}\left(121 \mathrm{MHz}, \mathrm{CDCl}_{3}\right) \delta 61.1(\mathrm{~s})$.

Racemic mixture of chloro $\{[(N, N$-dimethylamino $)$ methyl $]$ phenyl$C, N\}\left\{\left(R_{\mathrm{C}}, S_{\mathrm{P}}\right)-[3-(4-c h l o r o p h e n y l)-1-(1-n a p h t h y l) p r o p a n-3-o n y l](2-\right.$ methoxyphenyl)phenylphosphine $\}$ palladium(II), $\quad\left(R_{\mathrm{C}}, S_{\mathrm{P}}\right)-42 \quad$ and chloro $\left\{[(N, N\right.$-dimethylamino $)$ methyl]phenyl- $C, N\}\left\{\left(S_{\mathrm{C}}, R_{\mathrm{P}}\right)-[3-(4-\right.$ chlorophenyl)-1-(1-naphthyl)propan-3-onyl](2methoxyphenyl)phenylphosphine palladium(II), $\left(S_{\mathrm{C}}, \boldsymbol{R}_{\mathrm{P}}\right)$-42. Separation by silica gel column chromatography using hexanes/dichloromethane/acetone $(5: 1: 0.5, \mathrm{v} / \mathrm{v})$ as eluant gave a yellow solid $(0.052 \mathrm{~g}, 37 \%) .{ }^{31} \mathrm{P}\left\{{ }^{1} \mathrm{H}\right\}$ NMR $(202$ $\left.\mathrm{MHz}, \mathrm{CDCl}_{3}\right) \delta 44.8(\mathrm{~s})$.

Racemic mixture of dichlorodi- $\mu$-chlorobis $\left\{\left(R_{C}, R_{P}\right)\right.$-[3-(4-chlorophenyl)-1(1-naphthyl)propan-3-onyl](2-

methoxyphenyl)phenylphosphine $\}$ dipalladium(II), $\left(\boldsymbol{R}_{\mathrm{C}}, \boldsymbol{R}_{\mathrm{P}}, \boldsymbol{R}_{\mathrm{C}^{\prime}}, \boldsymbol{R}_{\mathrm{P}^{\prime}}\right)-39$ and dichlorodi- $\mu$-chlorobis $\left\{\left(S_{\mathrm{C}}, S_{\mathrm{P}}\right)\right.$-[3-(4-chlorophenyl)-1-(1-naphthyl)propan3-onyl](2-methoxyphenyl)phenylphosphine\}dipalladium(II), $\left(S_{\mathrm{C},}, S_{\mathrm{P}}, S_{\mathrm{C}^{\prime},} S_{\mathbf{P}^{\prime}}\right)$ 39. Conc. $\mathrm{HCl}(1 \mathrm{~mL})$ was added to a racemic mixture of $\left(R_{\mathrm{C}}, R_{\mathrm{P}}\right)-\mathbf{4 2}$ and $\left(S_{\left.\mathrm{C}, S_{\mathrm{P}}\right)-42}(0.30 \mathrm{~g}, 0.38 \mathrm{mmol})\right.$ in dichloromethane $(5 \mathrm{~mL})$. The yellow solution 
turned orange upon adding the conc. $\mathrm{HCl}$. The solution was stirred for an hour, and then quenched by water $(50 \mathrm{~mL})$. The organic phase was separated, further washed with water $(2 \times 50 \mathrm{~mL})$, dried with anhydrous $\mathrm{MgSO}_{4}$ and filtered. The solvent was removed under reduced pressure to give an orange solid $(0.26 \mathrm{~g}$, 98\%). ${ }^{31} \mathrm{P}\left\{{ }^{1} \mathrm{H}\right\}$ NMR (202 MHz, $\left.\mathrm{CDCl}_{3}\right) \delta 39.3(\mathrm{~s}), 39.7$ (s), $41.4(\mathrm{~s}), 41.9$ (s).

Racemic mixture of $\left(\boldsymbol{R}_{\mathrm{C}}, \boldsymbol{R}_{\mathrm{P}}, \boldsymbol{R}_{\mathrm{C}^{\prime}}, \boldsymbol{R}_{\mathrm{P}^{\prime}}\right)$-di- $\mu$-chlorobis $\{[3-(4-c h l o r o p h e n y l)-1-$ (1-naphthyl)propan-3-onyl](2-

methoxyphenyl)phenylphosphine $\}$ dipalladium(II), $\left(\boldsymbol{R}_{\mathrm{C}}, \boldsymbol{R}_{\mathrm{P}}, \boldsymbol{R}_{\mathrm{C}^{\prime}}, \boldsymbol{R}_{\mathrm{P}^{\prime}}\right)-40$ and $\left(S_{\mathrm{C}}, S_{\mathrm{P}}, S_{\mathrm{C}^{\prime}}, S_{\mathrm{P}^{\prime}}\right)$-di- $\mu$-chlorobis $\{[3-(4-c h l o r o p h e n y l)-1-(1-n a p h t h y l) p r o p a n-3-$ onyl](2-methoxyphenyl)phenylphosphine $)$ dipalladium(II), $\quad\left(S_{\mathrm{C}}, S_{\left.\mathrm{P}_{\mathrm{P}}, S_{\mathrm{C}^{\prime}}, S_{\mathrm{P}^{\prime}}\right)-}\right.$ 40. Racemic product mixture of $\left(R_{\mathrm{C}}, R_{\mathrm{P}}, R_{\mathrm{C}^{\prime}}, R_{\mathrm{P}^{\prime}}\right)-39$ and $\left(S_{\mathrm{C}}, S_{\mathrm{P}}, S_{\mathrm{C}^{\prime}}, S_{\mathrm{P}^{\prime}}\right)-39(0.26 \mathrm{~g}$, $0.19 \mathrm{mmol})$ was dissolved in ethanol $(10 \mathrm{~mL})$ and sodium acetate trihydrate $(0.73 \mathrm{~g})$ was added. The mixture was heated to reflux for $2 \mathrm{~h}$. After removing the solvent under reduced pressure, the crude product was dissolved in dichloromethane $(10 \mathrm{~mL})$, washed with water $(50 \mathrm{~mL} \times 2)$ and dried with anhydrous $\mathrm{MgSO}_{4}$. The crude product was then purified by silica gel column chromatography using hexanes/dichloromethane/acetone $(5: 1: 0.5, \mathrm{v} / \mathrm{v})$ as eluant to give a yellow solid $(0.097 \mathrm{~g}, 40 \%) .{ }^{31} \mathrm{P}\left\{{ }^{1} \mathrm{H}\right\} \mathrm{NMR}\left(202 \mathrm{MHz}, \mathrm{CDCl}_{3}\right) \delta 57.1$ (s), $57.6(\mathrm{~s})$. 
Racemic mixture of dichlorodi- $\mu$-chlorobis $\left\{\left(R_{C}, S_{P}\right)\right.$-[3-(4-chlorophenyl)-1(1-naphthyl)propan-3-onyl](2methoxyphenyl)phenylphosphine $\}$ dipalladium(II), $\left(\boldsymbol{R}_{\mathrm{C}}, S_{\mathrm{P}}, \boldsymbol{R}_{\left.\mathrm{C}^{\prime}, S_{\mathrm{P}^{\prime}}\right)-39}\right.$ and dichlorodi- $\mu$-chlorobis $\left\{\left(S_{\mathrm{C}}, R_{\mathrm{P}}\right)\right.$-[3-(4-chlorophenyl)-1-(1-naphthyl)propan3-onyl](2-methoxyphenyl)phenylphosphine\}dipalladium(II), $\left(\boldsymbol{S}_{\mathbf{C}}, \boldsymbol{R}_{\mathbf{P}}, \boldsymbol{S}_{\mathbf{C}^{\prime}}, \boldsymbol{R}_{\mathbf{P}^{\prime}}\right)$-39. Conc. $\mathrm{HCl}(1 \mathrm{~mL})$ was added to a racemic mixture of $\left(R_{\mathrm{C}}, S_{\mathrm{P}}\right)-\mathbf{4 2}$ and $\left(S_{\mathrm{C}}, R_{\mathrm{P}}\right) \mathbf{- 4 2}(0.052 \mathrm{~g}, 0.066 \mathrm{mmol})$ in dichloromethane $(5 \mathrm{~mL})$. The yellow solution turned orange upon adding the conc. $\mathrm{HCl}$. The solution was stirred for an hour, and then quenched by water $(50 \mathrm{~mL})$. The organic phase was separated, further washed with water $(2 \times 50 \mathrm{~mL})$, dried with anhydrous $\mathrm{MgSO}_{4}$ and filtered. The solvent was removed under reduced pressure to give an orange solid $(0.043 \mathrm{~g}, 94 \%) .{ }^{31} \mathrm{P}\left\{{ }^{1} \mathrm{H}\right\}$ NMR $(202 \mathrm{MHz}$, $\left.\mathrm{CDCl}_{3}\right) \delta 39.0(\mathrm{~s}), 40.9(\mathrm{~s})$.

Racemic mixture of $\left(R_{\mathrm{C}}, S_{\mathrm{P}}, R_{\mathrm{C}^{\prime},} S_{\mathrm{P}^{\prime}}\right)$-di- $\mu$-chlorobis\{[3-(4-chlorophenyl)-1-(1naphthyl)propan-3-onyl](2methoxyphenyl)phenylphosphine\}dipalladium(II), $\left(\boldsymbol{R}_{\mathrm{C},} S_{\mathrm{P}_{\mathrm{P}}}, \boldsymbol{R}_{\left.\mathrm{C}^{\prime}, S_{\mathrm{P}^{\prime}}\right)-40}\right.$ and $\left(S_{\mathrm{C}}, R_{\mathrm{P}}, S_{\mathrm{C}^{\prime}}, R_{\mathrm{P}^{\prime}}\right)$-di- $\mu$-chlorobis $\{[3-(4-c h l o r o p h e n y l)-1-(1-n a p h t h y l) p r o p a n-3-$ onyl](2-methoxyphenyl)phenylphosphine $\}$ dipalladium(II), $\quad\left(S_{\mathrm{C}}, R_{\left.\mathrm{P}, S_{\mathrm{C}^{\prime}}, R_{\mathrm{P}^{\prime}}\right)-}\right.$ 40. Racemic product mixture of $\left(R_{\mathrm{C}}, S_{\mathrm{P}}, R_{\mathrm{C}^{\prime}}, S_{\mathrm{P}^{\prime}}\right)-39$ and $\left(S_{\mathrm{C}}, R_{\mathrm{P}}, S_{\mathrm{C}^{\prime}}, R_{\mathrm{P}^{\prime}}\right)-39(0.043$ $\mathrm{g}, 0.031 \mathrm{mmol})$ was suspended in ethanol $(10 \mathrm{~mL})$ and sodium acetate trihydrate $(0.12 \mathrm{~g})$ was added. The mixture was heated to reflux for $2 \mathrm{~h}$. After removing the solvent under reduced pressure, the crude product was dissolved in dichloromethane $(10 \mathrm{~mL})$, washed with water $(50 \mathrm{~mL} \times 2)$ and dried with anhydrous $\mathrm{MgSO}_{4}$. The crude product was then purified by silica gel column chromatography using hexanes/dichloromethane/acetone $(5: 1: 0.5, \mathrm{v} / \mathrm{v})$ as eluant 
to give a yellow solid $(0.0054 \mathrm{~g}, 13 \%) .{ }^{31} \mathrm{P}\left\{{ }^{1} \mathrm{H}\right\}$ NMR $\left(202 \mathrm{MHz}, \mathrm{CDCl}_{3}\right) \delta$ $55.2(\mathrm{~s})$

Optical resolution of $\left(R_{\mathrm{C}}, R_{\mathrm{P}}, R_{\mathrm{C}^{\prime},}, R_{\mathrm{P}^{\prime}}\right)-40$ and $\left(S_{\mathrm{C}}, S_{\mathrm{P}}, S_{\mathrm{C}^{\prime},} S_{\mathrm{P}^{\prime}}\right)-40$. Isolation of $\left[(S)\right.$-prolinato] $\left\{\left(R_{\mathrm{C}}, R_{\mathrm{P}}\right)\right.$-1-[3-(4-chlorophenyl)-1-((2methoxyphenyl)phenylphosphino)propan-3-onyl]naphthyl$C, P\}$ palladium(II), $\quad\left(R_{\mathrm{C}}, R_{\mathrm{P}}, S_{\mathrm{N}}\right)-43 \quad$ and $\quad[(S)$-prolinato $]\left\{\left(S_{\mathrm{C}}, S_{\mathrm{P}}\right)-1-[3-(4-\right.$ chlorophenyl)-1-((2-methoxyphenyl)phenylphosphino)propan-3onyl]naphthyl- $\boldsymbol{C}, \boldsymbol{P}$ \}palladium(II), $\left(\boldsymbol{S}_{\mathrm{C},} \boldsymbol{S}_{\mathrm{P}}, S_{\mathrm{N}}\right)-43$. The racemic mixture of complexes $\left(R_{\mathrm{C}}, R_{\mathrm{P}}, R_{\mathrm{C}^{\prime}}, R_{\mathrm{P}^{\prime}}\right)-\mathbf{4 0}$ and $\left(S_{\mathrm{C}}, S_{\mathrm{P}}, S_{\mathrm{C}^{\prime}}, S_{\mathrm{P}^{\prime}}\right)-\mathbf{4 0}(0.093 \mathrm{~g}, 0.072 \mathrm{mmol})$ in dichloromethane $(5 \mathrm{~mL})$ was added to a solution of excess potassium $(S)$ prolinate $(\mathrm{KOH}$ and $(S)$-proline) in methanol $(5 \mathrm{~mL})$. The combined solution was stirred for $2 \mathrm{~h}$. The solvent was removed under reduced pressure, redissolved in dichloromethane, washed with water $(50 \mathrm{~mL} \mathrm{x} \mathrm{2)}$ and dried with anhydrous $\mathrm{MgSO}_{4}$. The dichloromethane was removed under reduced pressure to give a white solid. ${ }^{31} \mathrm{P}\left\{{ }^{1} \mathrm{H}\right\} \mathrm{NMR}\left(121 \mathrm{MHz}, \mathrm{CDCl}_{3}\right) 4$ signals in ca. 1.02 : $1.08: 1: 1.31$ ratio, $\delta 53.4(\mathrm{~s}), 54.1(\mathrm{~s}), 54.4(\mathrm{~s}), 55.1(\mathrm{~s})$.

$\left[(S)\right.$-Prolinato] $\left\{\left(R_{\mathrm{C}}, R_{\mathrm{P}}\right)\right.$-1-[3-(4-chlorophenyl)-1-((2methoxyphenyl)phenylphosphino)propan-3-onyl]naphthyl$\boldsymbol{C , P}$ \}palladium(II), $\left(\boldsymbol{R}_{\mathrm{C}}, \boldsymbol{R}_{\mathbf{P}}, \boldsymbol{S}_{\mathrm{N}}\right)$-43. The product was recrystallized from dichloromethane-diethyl ether to give white crystals $(0.046 \mathrm{~g}, 94 \%)$. mp 243$245{ }^{\circ} \mathrm{C}$ (dec); Anal. Calcd. for $\mathrm{C}_{37} \mathrm{H}_{33} \mathrm{ClNO}_{4} \mathrm{PPd}$ : C, 61.00; H, 4.57; N, 1.92 . Found: C, 60.39; H, 5.14; N, 2.47. ${ }^{31} \mathrm{P}\left\{{ }^{1} \mathrm{H}\right\} \mathrm{NMR}\left(121 \mathrm{MHz}, \mathrm{CDCl}_{3}\right) 54.1$ (s), $54.4(\mathrm{~s})$. 
$\left[(S)\right.$-Prolinato] $\left\{\left(S_{\mathrm{C}}, S_{\mathrm{P}}\right)\right.$-1-[3-(4-chlorophenyl)-1-((2-

methoxyphenyl)phenylphosphino)propan-3-onyl]naphthyl-

C,P palladium(II), $\left(S_{\mathrm{C}}, S_{\mathrm{P}}, S_{\mathrm{N}}\right)-43$. The product was recrystallized from dichloromethane-diethyl ether to give white crystals $(0.026 \mathrm{~g}, 47 \%) .{ }^{31} \mathrm{P}\left\{{ }^{1} \mathrm{H}\right\}$ NMR (121 MHz, $\left.\mathrm{CDCl}_{3}\right) 53.4(\mathrm{~s}), 55.1$ (s).

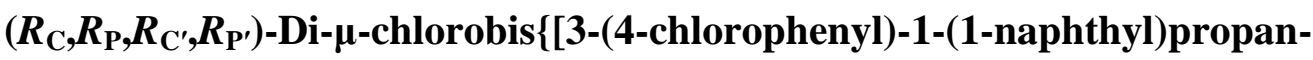
3-onyl](2-methoxyphenyl)phenylphosphine\}dipalladium(II),

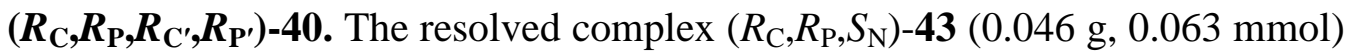
was dissolved in dichloromethane $(5 \mathrm{~mL})$. The solution was treated with $1 \mathrm{M}$ $\mathrm{HCl}(1 \mathrm{~mL})$ and stirred for $1 \mathrm{~h}$. The solution was washed with water $(50 \mathrm{~mL}$ x 2$)$ and dried with anhydrous $\mathrm{MgSO}_{4}$. The solvent was removed under reduced pressure to give the produce as a yellow solid $(0.040 \mathrm{~g}, 99 \%) .{ }^{31} \mathrm{P}\left\{{ }^{1} \mathrm{H}\right\} \mathrm{NMR}$ $\left(202 \mathrm{MHz}, \mathrm{CDCl}_{3}\right) \delta 57.5(\mathrm{~s}), 57.7(\mathrm{~s})$.

$\left(S_{\mathrm{C},} S_{\mathrm{P}}, S_{\mathrm{C}^{\prime},} S_{\mathrm{P}^{\prime}}\right)$-Di- $\mu$-chlorobis $\left\{\left(S_{\mathrm{C},} S_{\mathrm{P}}\right)\right.$-[3-(4-chlorophenyl)-1-(1naphthyl)propan-3-onyl](2-

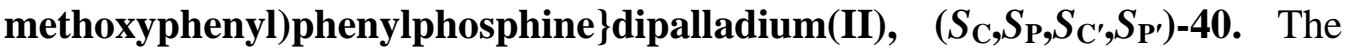
resolved complex $\left(S_{\mathrm{C}}, S_{\mathrm{P}}, S_{\mathrm{N}}\right)-\mathbf{4 3}(0.026 \mathrm{~g}, 0.036 \mathrm{mmol})$ was dissolved in dichloromethane $(5 \mathrm{~mL})$. The solution was treated with $1 \mathrm{M} \mathrm{HCl}(1 \mathrm{~mL})$ and stirred for $1 \mathrm{~h}$. The solution was washed with water $(50 \mathrm{~mL}$ x 2$)$ and dried with anhydrous $\mathrm{MgSO}_{4}$. The solvent was removed under reduced pressure to give the produce as a yellow solid $(0.023 \mathrm{~g}, 97 \%) .[\alpha]_{\mathrm{D}}=+418^{\circ}\left(c=2.3, \mathrm{CH}_{2} \mathrm{Cl}_{2}\right)$; ${ }^{31} \mathrm{P}\left\{{ }^{1} \mathrm{H}\right\}$ NMR (202 MHz, $\left.\mathrm{CDCl}_{3}\right) \delta 57.5$ (s), 57.7 (s). 


\section{Chloro\{ $\left(S_{\mathrm{C}} S_{\mathrm{P}}\right)$-1-[3-(4-chlorophenyl)-1-((2-}

methoxyphenyl)phenylphosphino)propan-3-onyl]naphthyl-

$\boldsymbol{C , P}$ \}(triphenylphosphine)palladium(II), $\left(\boldsymbol{S}_{\mathrm{C}}, S_{\mathrm{P}}\right)-41$. The dimer complex $\left(S_{\mathrm{C}}, S_{\mathrm{P}}, S_{\mathrm{C}^{\prime}}, S_{\mathrm{P}^{\prime}}\right)-43(0.023 \mathrm{~g}, 0.017 \mathrm{mmol})$ was dissolved in dichloromethane (5 $\mathrm{mL})$. Triphenylphosphine (0.0091 g, $0.0035 \mathrm{mmol}, 2$ equiv.) was added and stirred for $30 \mathrm{~min}$. The solvent was removed under pressure to give product as yellow solid. The product cannot be induced to crystallize despite the use of a variety of solvents. ${ }^{31} \mathrm{P}\left\{{ }^{1} \mathrm{H}\right\} \mathrm{NMR}\left(202 \mathrm{MHz}, \mathrm{CDCl}_{3}\right) 4$ sets of signals in ca. 1 : $1.6: 1.6: 1$ ratio, $\delta 17.6\left(\mathrm{~d},{ }^{2} J_{\mathrm{PP}}=27.0 \mathrm{~Hz}\right.$, coordinated $P \mathrm{Ph}_{3}$ ligand of cis geometric isomer), $25.5\left(\mathrm{~d},{ }^{2} J_{\mathrm{PP}}=426.6 \mathrm{~Hz}\right.$, coordinated $\mathrm{PPh}_{3}$ ligand of trans geometric isomer), $49.5\left(\mathrm{~d},{ }^{2} J_{\mathrm{PP}}=426.6 \mathrm{~Hz}\right.$, phosphapalladacycle $P$ of trans geometric isomer), $54.0\left(\mathrm{~d},{ }^{2} J_{\mathrm{PP}}=27.0 \mathrm{~Hz}\right.$, phosphapalladacycle $P$ of cis geometric isomer).

\section{[1,2-Bis(diphenylphosphino)ethane- $\left.P, P^{\prime}\right]\left\{\left(S_{\mathrm{C}}, S_{\mathrm{P}}\right)\right.$-1-[3-(4-chlorophenyl)-1-}

\section{((2-methoxyphenyl)phenylphosphino)propan-3-onyl]naphthyl-}

$\boldsymbol{C}, \boldsymbol{P}$ \}palladium(II) chloride, $\left(\boldsymbol{S}_{\mathrm{C}}, S_{\mathrm{P}}\right)$-44. 1,2-Bis(diphenylphosphino)ethane $(0.0097 \mathrm{~g}, 0.024 \mathrm{mmol})$ was added to a solution of $\left(S_{\mathrm{C}}, S_{\mathrm{P}}, S_{\mathrm{C}^{\prime}}, S_{\mathrm{P}^{\prime}}\right)-\mathbf{4 0}(0.016 \mathrm{~g}$, $0.012 \mathrm{mmol})$ in dichloromethane $(5 \mathrm{~mL})$. After stirring for $2 \mathrm{~h}$, the solvent was removed under reduced pressure to give a yellow solid. The product cannot be induced to crystallize despite the use of a variety of solvents. ${ }^{31} \mathrm{P}\left\{{ }^{1} \mathrm{H}\right\} \mathrm{NMR}$ $\left(202 \mathrm{MHz}, \mathrm{CDCl}_{3}\right) \delta 42.2\left(\mathrm{dd},{ }^{2} J_{\mathrm{P}(\text { trans }) \mathrm{P}(\text { (cis })}=28.3 \mathrm{~Hz},{ }^{2} J_{\mathrm{P}-\mathrm{P}(\text { cis })}=22.7 \mathrm{~Hz}\right.$, coordinated dppe ligand $P$ cis to phosphapalladacycle $\mathrm{P}), 45.1\left(\mathrm{dd},{ }^{2} J_{\mathrm{P}-\mathrm{P}(\text { trans })}=\right.$ $351.2 \mathrm{~Hz},{ }^{2} J_{\mathrm{P}(\text { trans }) \mathrm{P}(\text { cis })}=28.3 \mathrm{~Hz}$, coordinated dppe ligand $P$ trans to phosphapalladacycle P), $51.8\left(\mathrm{dd},{ }^{2} \boldsymbol{J}_{\mathrm{P}-\mathrm{P}(\text { trans })}=351.6 \mathrm{~Hz},{ }^{2} \boldsymbol{J}_{\mathrm{P}-\mathrm{P}(\text { cis })}=22.7 \mathrm{~Hz}\right.$, phosphapalladacycle $P$ ). 


\section{CHAPTER 4: ASYMMETRIC SYNTHESIS OF ISOQUINOLINE-BASED CHIRAL P,N BIDENTATE LIGANDS}

\subsection{Introduction}

$\mathrm{P}, \mathrm{N}$ Bidentate ligands, consisting of a chelating $\mathrm{P}$ and $\mathrm{N}$ donor atoms, are an interesting class of ligands. This type of asymmetrical ligands possesses a combination of hard $(\mathrm{N})$ and soft $(\mathrm{P})$ donor atoms, and therefore have different features associated with each donor atom that provide unique reactivity to their metal complexes in catalytic asymmetric processes. ${ }^{43-44}$

Isoquinoline-based $\mathrm{P}, \mathrm{N}$ ligands are usually in the form of atropisomeric axial chiral biaryl complexes such as QUINAP and its derivatives. ${ }^{45-46}$

Developing isoquinoline-based $\mathrm{P}, \mathrm{N}$ ligands is of particular interest to this project because of the structural similarity of the isoquinoline ring and the naphthalene ring. In the naphthylamine and naphthylphosphine complexes discussed in the previous chapters, steric interaction between $\mathrm{H}(8)$ on the naphthyl ring and a substituent on the 5-member palladacycle ring locks the ring into a stable conformation, contributing to the effective controlling of stereoselectivity in asymmetric reactions. The same steric interaction is expected to be present in the analogous isoquinoline-based $\mathrm{P}, \mathrm{N}$ ligands coordinated with a palladium metal centre in a 5-membered ring formation.

The combination of the $\mathrm{H}(8)$ steric factor and the electronic properties of $\mathrm{P}, \mathrm{N}$ ligands in the proposed isoquinoline-based $\mathrm{P}, \mathrm{N}$ palladium complexes may open up new possibilities for use in a wide range of reactions. The neutral 
$\mathrm{N}$ in place of the anionic $\mathrm{C}$ will have an effect on the activity of the Pd metal centre. The formal charge on the Pd centre would be +2 , and the increase in polarity may make it more useful in more polar solvents.

\subsection{Research Objectives}

The research objectives are to synthesize an isoquinoline-based palladium complex from the hydrophosphination product of 1-isoquinoline enones via the catalytic approach or the stoichiometric approach. Similar to Chapter 3, the diphenylphosphine can be replaced by a P-chiral secondary phosphine $o$-anisylphenylphosphine for the synthesis of a P,N ligand-based palladium complex with two chiral centres at the carbon and phosphorus atoms.

Leung and coworkers had previously reported the asymmetric hydrophosphination reaction of (E)-1-phenyl-3-pyridin-2-yl-2-propenone with diphenylphosphine, promoted by a stoichiometric amount of chiral bis(acetonitrile) complex $(R)-2$, in high regio- and stereoselectivities under mild conditions. $^{47}$ The same technique can be used in the asymmetric hydrophosphination reactions of the isoquinoline analogue $(E)$-3-isoquinoline1-yl-1-phenyl-2-propenone, $\mathbf{4 5}$, with secondary phosphines.

In addition to using a stoichiometric amount of complex $(R)-5$, the same reaction is also studied with a catalytic amount of $(R)-\mathbf{5}$. 


\subsection{Results and Discussion}

\subsubsection{Asymmetric hydrophosphination with diphenylphosphine promoted by stoichiometric amount of Pd complex}

The reaction between 45 and diphenylphosphine proceeded at room temperature in the presence of stoichiometric amount of the chiral template $(R)$ 5 (Scheme 4.1).

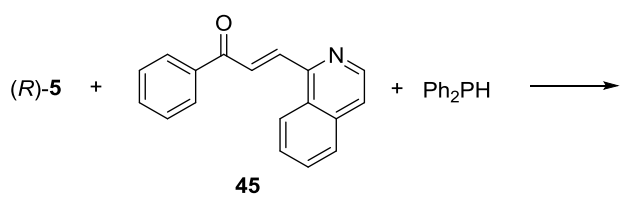

Scheme 4.1

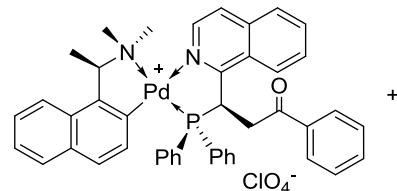

$(R, R)-46$

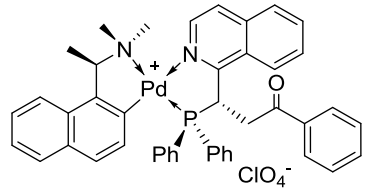

$(R, S)-46$

The reaction was found to be completed in 2 hours. The ${ }^{31} \mathrm{P}\left\{{ }^{1} \mathrm{H}\right\}$ NMR spectrum showed two singlet peaks at $\delta 55.4$ and $\delta 59.1$ in 2.5:1 ratio, corresponding to the formation of two disastereomeric products. The absence of additional peaks also indicates the $100 \%$ regioselectivity of the reaction, where the diphenylphosphine coordinates exclusively trans to the $\mathrm{NMe}_{2}$. The high regioselectivity observed is consistent with what has been observed in other P,N heterobidentate ligands. ${ }^{47-48}$

The diastereomeric products can be separated by column chromatography and fractional crystallization. Pure $(R, R)-\mathbf{4 6}\left([\alpha]_{\mathrm{D}}=-250^{\circ}(c=\right.$ 1, $\left.\left.\mathrm{CH}_{2} \mathrm{Cl}_{2}\right)\right)$ and $(R, S)-46\left([\alpha]_{\mathrm{D}}=+255^{\circ}\left(c=1, \mathrm{CH}_{2} \mathrm{Cl}_{2}\right)\right)$ were obtained separately. The less soluble minor product $(R, S)-\mathbf{4 6}$ was crystallized first from dichloromethane-diethyl ether as white crystals. The ${ }^{31} \mathrm{P}\left\{{ }^{1} \mathrm{H}\right\}$ NMR spectrum showed a singlet peak at $\delta 59.1$. The properties and absolute configuration of $(R, S)$-46 were studied by single-crystal X-ray crystallography (Figure 4.1). 


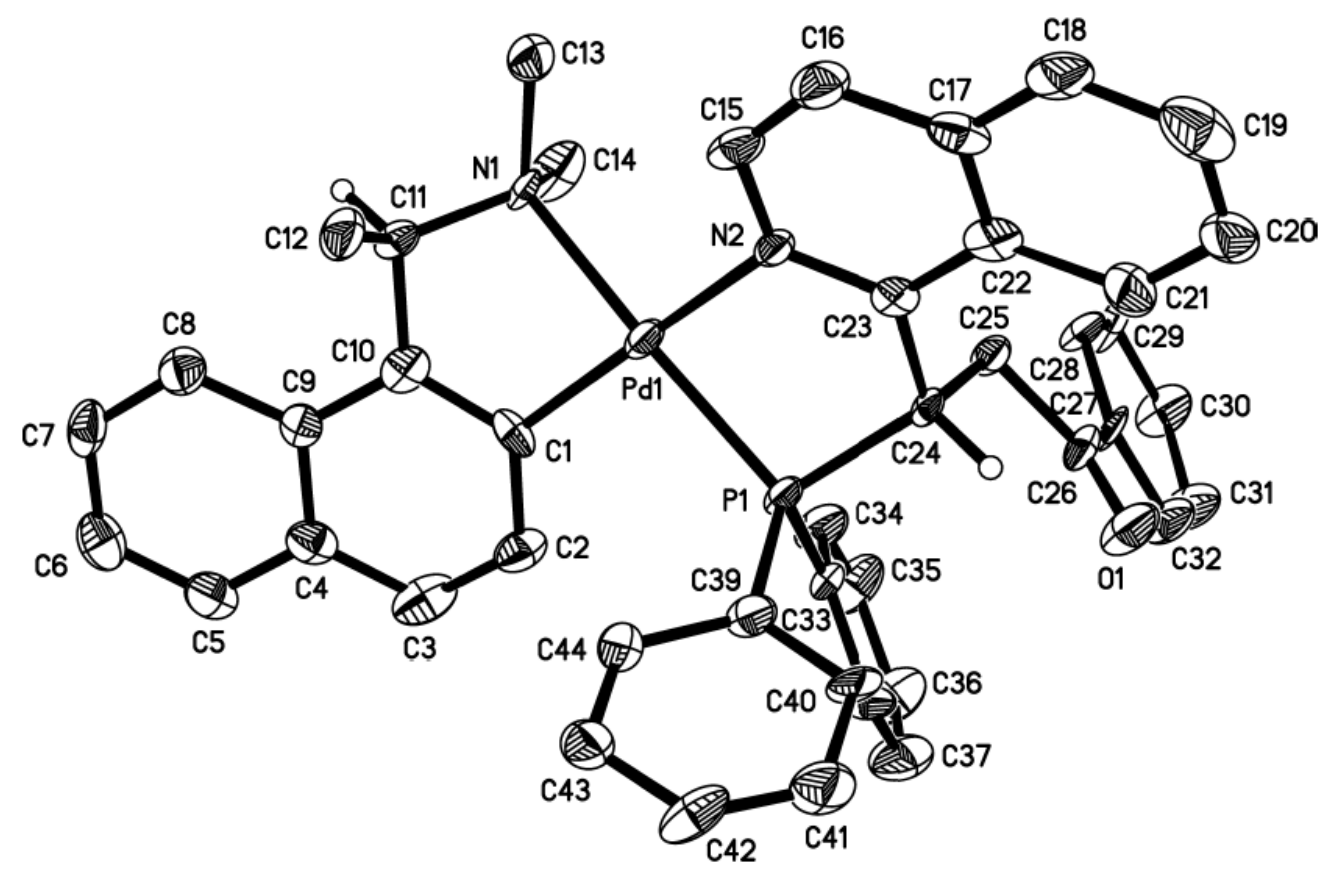

Figure 4.1 X-ray molecular structure of $(R, S)-46$

Table 4.1 Selected bond lengths $(\AA)$ and angles $\left(^{\circ}\right)$ of $(R, S)-46$

\begin{tabular}{llll}
\hline $\mathrm{Pd}(1)-\mathrm{C}(1)$ & $2.028(9)$ & $\mathrm{Pd}(1)-\mathrm{N}(1)$ & $2.156(7)$ \\
$\mathrm{Pd}(1)-\mathrm{N}(2)$ & $2.186(8)$ & $\mathrm{Pd}(1)-\mathrm{P}(1)$ & $2.228(2)$ \\
$\mathrm{C}(15)-\mathrm{N}(2)$ & $1.357(12)$ & $\mathrm{C}(23)-\mathrm{N}(2)$ & $1.345(12)$ \\
$\mathrm{C}(23)-\mathrm{C}(24)$ & $1.498(13)$ & $\mathrm{C}(24)-\mathrm{P}(1)$ & $1.837(9)$ \\
$\mathrm{C}(24)-\mathrm{C}(25)$ & $1.571(12)$ & $\mathrm{C}(25)-\mathrm{C}(26)$ & $1.523(12)$ \\
$\mathrm{C}(26)-\mathrm{O}(1)$ & $1.199(12)$ & $\mathrm{C}(26)-\mathrm{C}(27)$ & $1.478(15)$ \\
$\mathrm{C}(33)-\mathrm{P}(1)$ & $1.800(10)$ & $\mathrm{C}(39)-\mathrm{P}(1)$ & $1.825(10)$ \\
& & & \\
$\mathrm{C}(1)-\mathrm{Pd}(1)-\mathrm{N}(1)$ & $79.3(4)$ & $\mathrm{C}(1)-\mathrm{Pd}(1)-\mathrm{N}(2)$ & $167.5(3)$ \\
$\mathrm{N}(1)-\mathrm{Pd}(1)-\mathrm{N}(2)$ & $103.8(3)$ & $\mathrm{C}(1)-\mathrm{Pd}(1)-\mathrm{P}(1)$ & $98.6(3)$ \\
$\mathrm{N}(1)-\mathrm{Pd}(1)-\mathrm{P}(1)$ & $170.4(2)$ & $\mathrm{N}(2)-\mathrm{Pd}(1)-\mathrm{P}(1)$ & $80.2(2)$ \\
$\mathrm{N}(2)-\mathrm{C}(23)-\mathrm{C}(24)$ & $116.3(8)$ & $\mathrm{C}(23)-\mathrm{C}(24)-\mathrm{C}(25)$ & $110.9(7)$ \\
$\mathrm{C}(23)-\mathrm{C}(24)-\mathrm{P}(1)$ & $109.2(6)$ & $\mathrm{C}(25)-\mathrm{C}(24)-\mathrm{P}(1)$ & $111.8(7)$ \\
$\mathrm{C}(26)-\mathrm{C}(25)-\mathrm{C}(24)$ & $110.9(7)$ & $\mathrm{O}(1)-\mathrm{C}(26)-\mathrm{C}(27)$ & $122.0(9)$ \\
$\mathrm{O}(1)-\mathrm{C}(26)-\mathrm{C}(25)$ & $121.8(10)$ & $\mathrm{C}(27)-\mathrm{C}(26)-\mathrm{C}(25)$ & $116.2(8)$ \\
$\mathrm{C}(23)-\mathrm{N}(2)-\mathrm{Pd}(1)$ & $119.6(6)$ & $\mathrm{C}(24)-\mathrm{P}(1)-\mathrm{Pd}(1)$ & $100.7(3)$ \\
\hline
\end{tabular}

X-ray structure analysis showed that the newly-formed stereogenic centre at $\mathrm{C}(24)$ adopted the $S$ absolute configuration. The crystal structure obtained confirmed the formation of the $\mathrm{P}, \mathrm{N}$-chelate 5-membered ring structure. 
The geometry at the Pd centre is distorted square planar with angles of 79.3(4)103.8(3) and $167.5(3)-170.4(2)^{\circ}$. The $\mathrm{CH}_{2} \mathrm{COPh}$ group at $\mathrm{C}(24)$ is in the axial position, suggesting that steric repulsion with the $H$ on the $C(21)$ in the isoquinoline ring forces it to adopt the usually less favourable position. The same phenomenon was found in naphthalene based palladacycles, where the steric repulsion between the methyl group at the stereogenic centre and the $H(8)$ on the naphthalene ring forces the methyl group to adopt the axial position. ${ }^{27,30}$ In contrast, the $\mathrm{CH}_{2} \mathrm{COPh}$ group on the pyridine analogue adopts the usually favourable equatorial position in the absence of the steric repulsion. ${ }^{47}$

The compound $(R, S)-\mathbf{4 6}$ was treated with concentrated hydrochloric acid to remove the naphthylamine auxiliary, giving the dichloro complex $(S)-47$ (Scheme 4.2).

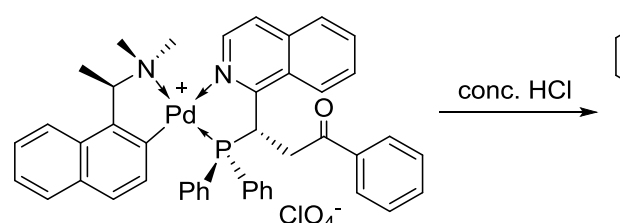

$(R, S)-46$

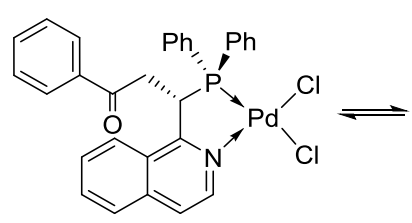

$(S)-47$

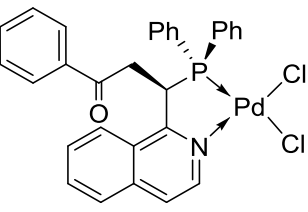

$(R)-47$

Scheme 4.2

The ${ }^{31} \mathrm{P}\left\{{ }^{1} \mathrm{H}\right\}$ NMR spectrum showed a singlet peak at $\delta$ 51.9. After a few days, the dichloro complex was crystallized from dichloromethane-diethyl ether as yellow crystals and X-ray crystallographic study was performed (Figure 4.2). 


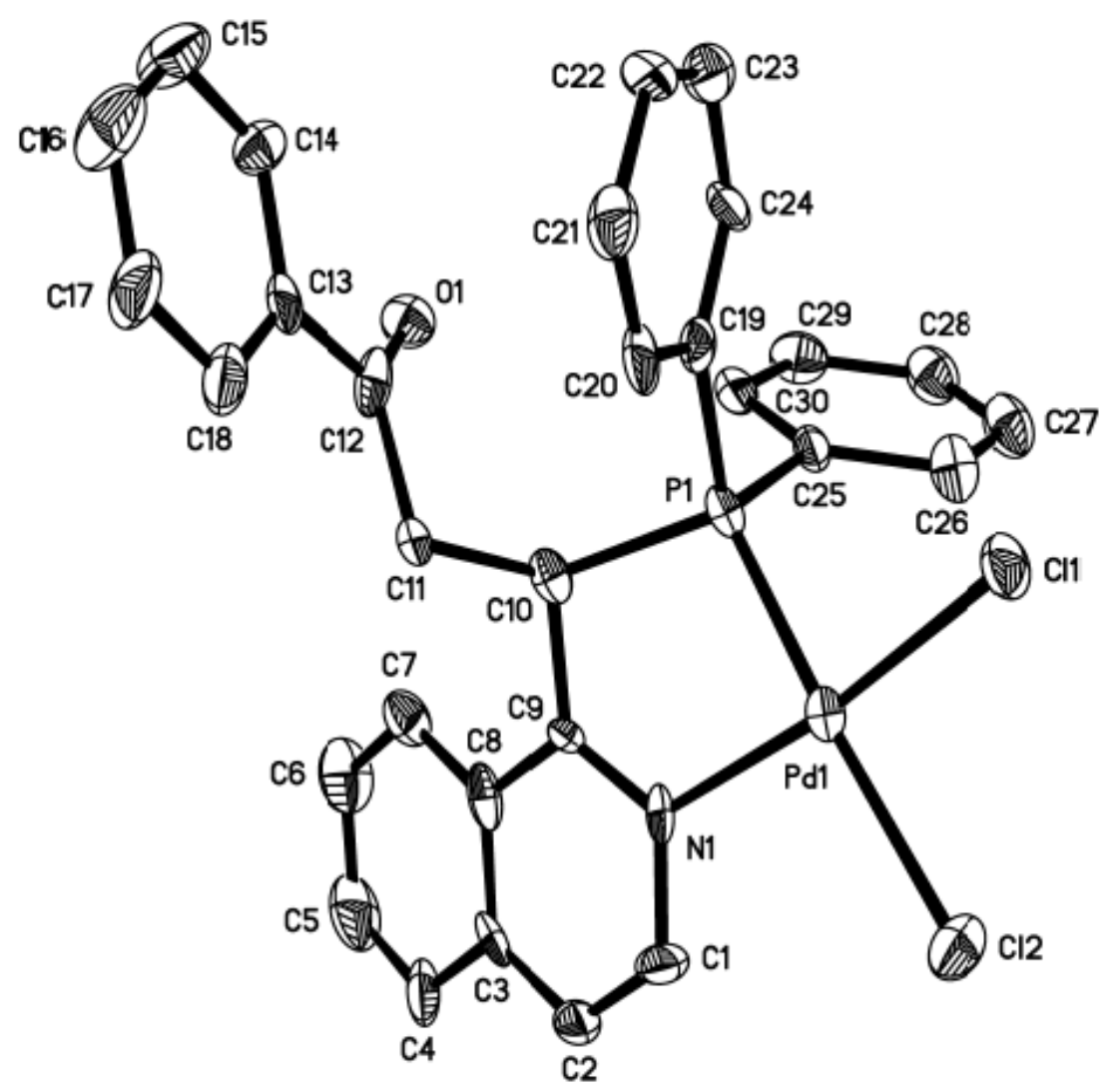

Figure 4.2 X-ray molecular structure of $\mathrm{rac}-47$

Table 4.2 Selected bond lengths $(\AA)$ and angles $\left(^{\circ}\right)$ of $r a c-47$

\begin{tabular}{llll}
\hline $\mathrm{Pd}(1)-\mathrm{N}(1)$ & $2.067(7)$ & $\mathrm{Pd}(1)-\mathrm{P}(1)$ & $2.208(2)$ \\
$\mathrm{Pd}(1)-\mathrm{Cl}(1)$ & $2.295(2)$ & $\mathrm{Pd}(1)-\mathrm{Cl}(2)$ & $2.388(2)$ \\
$\mathrm{C}(1)-\mathrm{N}(1)$ & $1.390(11)$ & $\mathrm{C}(9)-\mathrm{N}(1)$ & $1.334(11)$ \\
$\mathrm{C}(9)-\mathrm{C}(10)$ & $1.529(12)$ & $\mathrm{C}(10)-\mathrm{P}(1)$ & $1.846(8)$ \\
$\mathrm{C}(10)-\mathrm{C}(11)$ & $1.562(12)$ & $\mathrm{C}(11)-\mathrm{C}(12)$ & $1.508(13)$ \\
$\mathrm{C}(12)-\mathrm{O}(1)$ & $1.216(10)$ & $\mathrm{C}(12)-\mathrm{C}(13)$ & $1.482(12)$ \\
$\mathrm{C}(19)-\mathrm{P}(1)$ & $1.826(9)$ & $\mathrm{C}(25)-\mathrm{P}(1)$ & $1.835(9)$ \\
& & & \\
$\mathrm{N}(1)-\mathrm{Pd}(1)-\mathrm{P}(1)$ & $83.9(2)$ & $\mathrm{N}(1)-\mathrm{Pd}(1)-\mathrm{Cl}(1)$ & $173.4(2)$ \\
$\mathrm{P}(1)-\mathrm{Pd}(1)-\mathrm{Cl}(1)$ & $89.73(8)$ & $\mathrm{N}(1)-\mathrm{Pd}(1)-\mathrm{Cl}(2)$ & $95.3(2)$ \\
$\mathrm{P}(1)-\mathrm{Pd}(1)-\mathrm{Cl}(2)$ & $172.14(9)$ & $\mathrm{Cl}(1)-\mathrm{Pd}(1)-\mathrm{Cl}(2)$ & $91.24(8)$ \\
$\mathrm{N}(1)-\mathrm{C}(9)-\mathrm{C}(10)$ & $119.0(7)$ & $\mathrm{C}(9)-\mathrm{C}(10)-\mathrm{C}(11)$ & $110.7(7)$ \\
$\mathrm{C}(9)-\mathrm{C}(10)-\mathrm{P}(1)$ & $107.3(6)$ & $\mathrm{C}(11)-\mathrm{C}(10)-\mathrm{P}(1)$ & $113.5(6)$ \\
$\mathrm{C}(12)-\mathrm{C}(11)-\mathrm{C}(10)$ & $110.1(7)$ & $\mathrm{O}(1)-\mathrm{C}(12)-\mathrm{C}(13)$ & $121.7(9)$ \\
$\mathrm{O}(1)-\mathrm{C}(12)-\mathrm{C}(11)$ & $119.7(8)$ & $\mathrm{C}(13)-\mathrm{C}(12)-\mathrm{C}(11)$ & $118.5(8)$ \\
$\mathrm{C}(9)-\mathrm{N}(1)-\mathrm{Pd}(1)$ & $120.7(6)$ & $\mathrm{C}(10)-\mathrm{P}(1)-\mathrm{Pd}(1)$ & $103.1(3)$ \\
\hline
\end{tabular}


X-ray crystallography of $\mathbf{4 7}$ revealed that racemization had occurred at the $\mathrm{C}(10)$ chiral centre. The racemization of an isoquinoline based $\mathrm{P}, \mathrm{N}$ bidentate ligand was reported by Claridge et al. ${ }^{49}$ The racemization even occurred when the ligand is coordinated to $\mathrm{PdCl}_{2}$, but the rate was slower than the free ligand, showing the lability of the P,N chelate and ligand dissociation or partial dissociation from $\mathrm{PdCl}_{2}$ before inversion.

\subsubsection{Catalytic asymmetric hydrophosphination with diphenylphosphine promoted by catalytic amount of Pd complex}

The hydrophosphination reaction between $\mathbf{4 5}$ and diphenylphosphine was repeated with catalytic amount of $(R)-5$ (Scheme 4.3).

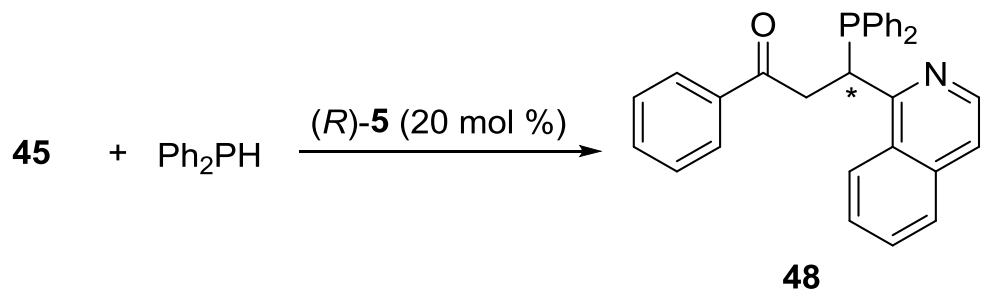

\section{Scheme 4.3}

Monitoring the reaction with ${ }^{31} \mathrm{P}\left\{{ }^{1} \mathrm{H}\right\} \mathrm{NMR}$, a new singlet peak at $\delta 3.0$ was found in the spectrum after 2 hours. The reaction was allowed to proceed for 3 days at $-80^{\circ} \mathrm{C}$ until the reaction did not proceed any further. The reaction temperature was raised to room temperature and stirred for another 1 day, after which the diphenylphosphine was found to be completely consumed. The calculated yield from the NMR spectrum was $73 \%$.

The free phosphine product was coordinated to $(R)-\mathbf{4}$ for the determination of ee (Scheme 4.4). 


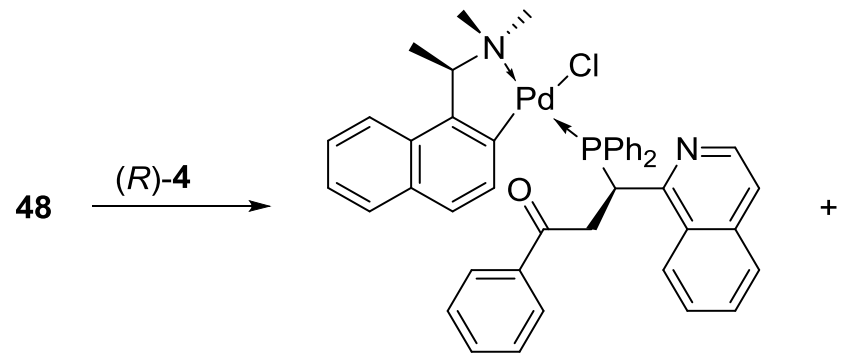

$(R, R)-49$

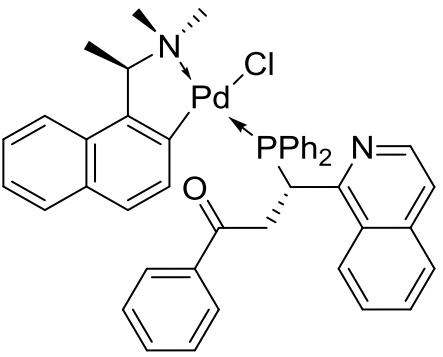

$(R, S)-49$

Scheme 4.4

The ${ }^{31} \mathrm{P}\left\{{ }^{1} \mathrm{H}\right\}$ NMR spectrum showed two singlet peaks at $\delta 53.0$ and 54.8 in 1:1 ratio. This apparent lack of stereoselectivity was due to the racemization of the product as described earlier.

\subsubsection{Asymmetric hydrophosphination with $o$-anisylphenylphosphine promoted by stoichiometric amount of Pd complex}

The reaction was repeated with a P-chiral secondary phosphine, $o$ anisylphenylphosphine in place of diphenylphosphine. The reaction with stoichiometric amount of $(R)-\mathbf{5}$ proceeded at room temperature and completed in 3 days (Scheme 4.5).
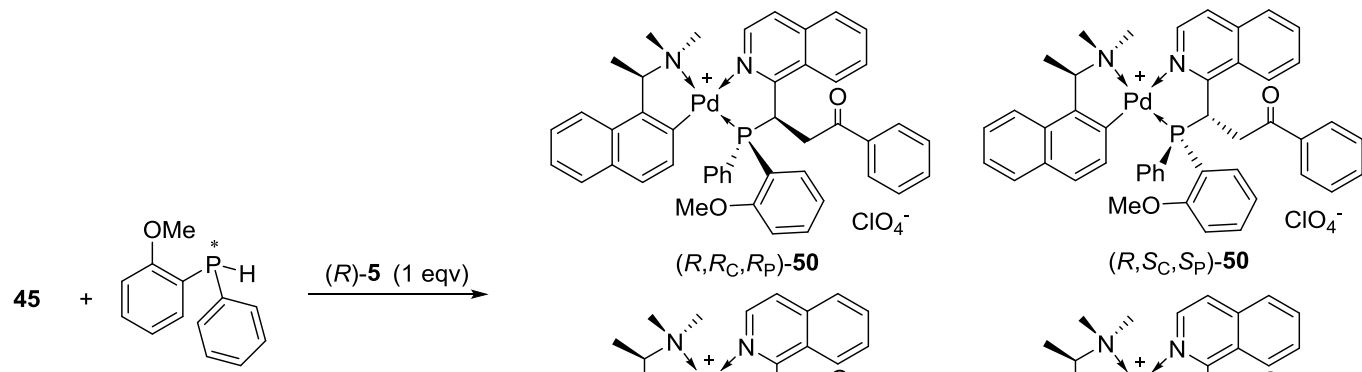

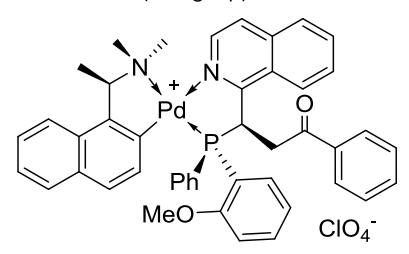

$\left(R, R_{\mathrm{C}}, S_{\mathrm{P}}\right)-\mathbf{5 0}$

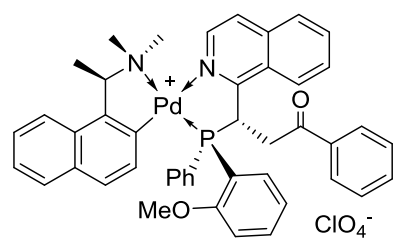

$\left(R, S_{\mathrm{C}}, R_{\mathrm{P}}\right)-50$

Scheme 4.5 
The ${ }^{31} \mathrm{P}\left\{{ }^{1} \mathrm{H}\right\}$ NMR spectrum exhibited 4 peaks corresponding to 4 stereoisomeric products at $\delta 46.4,50.4,55.6$ and 58.4 in the ratio of $1: 3.6$ : $1.6: 2.1$. The major product at $\delta 50.4,\left(R, R_{\mathrm{C}}, R_{\mathrm{P}}\right)-\mathbf{5 0}$ was isolated as white crystals from dichloromethane-diethyl ether and X-ray analysis was performed (Figure 4.3).

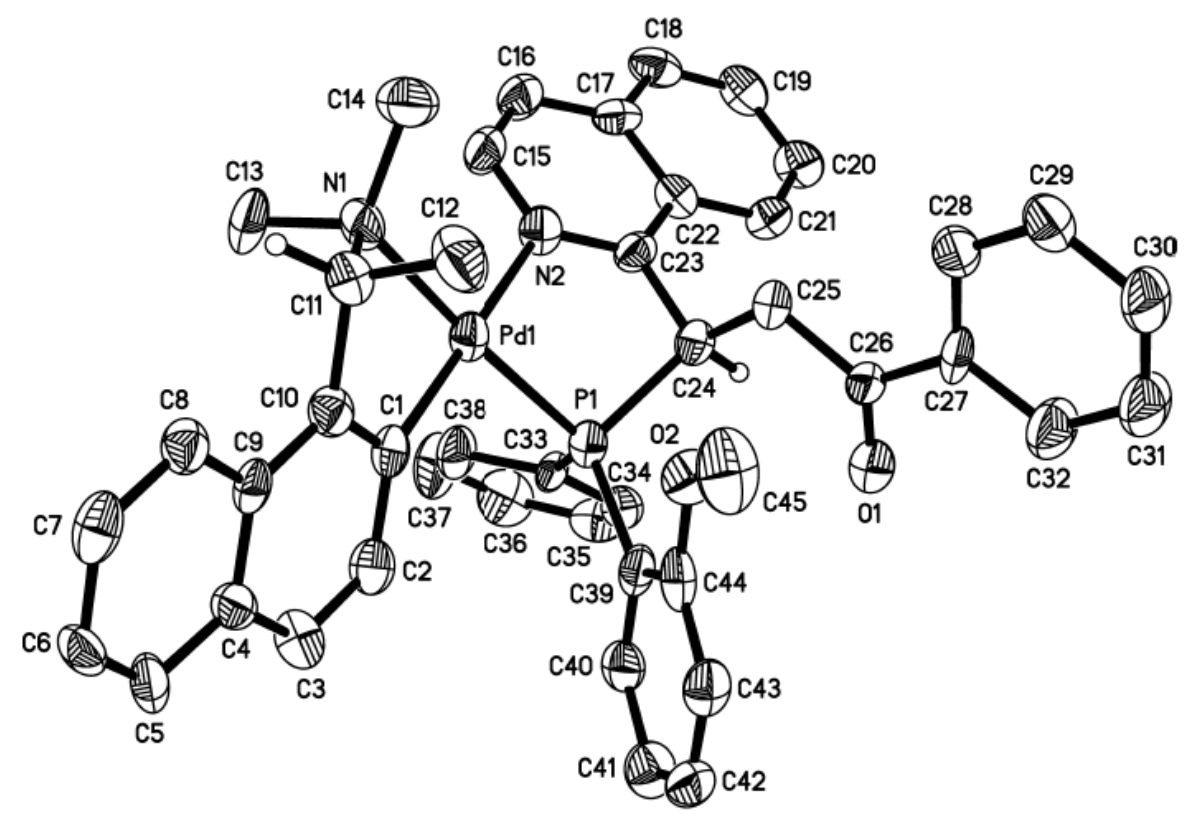

Figure 4.3 X-ray molecular structure of $\left(R, R_{C}, R_{P}\right)-50$

Table 4.3 Selected bond lengths $(\AA)$ and angles $\left({ }^{\circ}\right)$ of $\left(R, R_{\mathrm{C}}, R_{\mathrm{P}}\right)-50$

\begin{tabular}{llll}
\hline $\mathrm{Pd}(1)-\mathrm{C}(1)$ & $2.002(9)$ & $\mathrm{Pd}(1)-\mathrm{N}(1)$ & $2.140(8)$ \\
$\mathrm{Pd}(1)-\mathrm{N}(2)$ & $2.152(7)$ & $\mathrm{Pd}(1)-\mathrm{P}(1)$ & $2.226(2)$ \\
$\mathrm{C}(15)-\mathrm{N}(2)$ & $1.395(11)$ & $\mathrm{C}(23)-\mathrm{N}(2)$ & $1.348(11)$ \\
$\mathrm{C}(23)-\mathrm{C}(24)$ & $1.503(12)$ & $\mathrm{C}(24)-\mathrm{P}(1)$ & $1.886(9)$ \\
$\mathrm{C}(24)-\mathrm{C}(25)$ & $1.556(12)$ & $\mathrm{C}(25)-\mathrm{C}(26)$ & $1.499(11)$ \\
$\mathrm{C}(26)-\mathrm{O}(1)$ & $1.226(10)$ & $\mathrm{C}(26)-\mathrm{C}(27)$ & $1.501(12)$ \\
$\mathrm{C}(33)-\mathrm{P}(1)$ & $1.814(9)$ & $\mathrm{C}(39)-\mathrm{P}(1)$ & $1.793(9)$ \\
& & & \\
$\mathrm{C}(1)-\mathrm{Pd}(1)-\mathrm{N}(1)$ & $80.7(3)$ & $\mathrm{C}(1)-\mathrm{Pd}(1)-\mathrm{N}(2)$ & $173.6(3)$ \\
$\mathrm{N}(1)-\mathrm{Pd}(1)-\mathrm{N}(2)$ & $102.4(3)$ & $\mathrm{C}(1)-\mathrm{Pd}(1)-\mathrm{P}(1)$ & $98.9(3)$ \\
$\mathrm{N}(1)-\mathrm{Pd}(1)-\mathrm{P}(1)$ & $172.9(2)$ & $\mathrm{N}(2)-\mathrm{Pd}(1)-\mathrm{P}(1)$ & $78.7(2)$ \\
$\mathrm{N}(2)-\mathrm{C}(23)-\mathrm{C}(24)$ & $115.0(8)$ & $\mathrm{C}(23)-\mathrm{C}(24)-\mathrm{C}(25)$ & $111.3(7)$ \\
$\mathrm{C}(23)-\mathrm{C}(24)-\mathrm{P}(1)$ & $104.1(6)$ & $\mathrm{C}(25)-\mathrm{C}(24)-\mathrm{P}(1)$ & $117.8(6)$ \\
$\mathrm{C}(26)-\mathrm{C}(25)-\mathrm{C}(24)$ & $112.6(7)$ & $\mathrm{O}(1)-\mathrm{C}(26)-\mathrm{C}(25)$ & $121.8(8)$ \\
$\mathrm{O}(1)-\mathrm{C}(26)-\mathrm{C}(27)$ & $120.1(8)$ & $\mathrm{C}(25)-\mathrm{C}(26)-\mathrm{C}(27)$ & $118.1(7)$ \\
$\mathrm{C}(23)-\mathrm{N}(2)-\mathrm{Pd}(1)$ & $120.9(6)$ & $\mathrm{C}(24)-\mathrm{P}(1)-\mathrm{Pd}(1)$ & $98.8(3)$ \\
\hline
\end{tabular}


The product $\left(R, R_{\mathrm{C}}, R_{\mathrm{P}}\right)-\mathbf{5 0}$ was found to have adopted the $R$ configuration at the $\mathrm{C}(24)$ chiral centre and $R$ configuration at the $\mathrm{P}(1)$ chiral centre. The geometry at the Pd centre is distorted square planar with angles of $78.7(2)-102.4(3)^{\circ}$ and $172.9(2)-173.6(3)^{\circ}$. Steric repulsion from the $H$ on the $\mathrm{C}(21)$ in the isoquinoline ring forces the $\mathrm{CH}_{2} \mathrm{COPh}$ group at $\mathrm{C}(24)$ to adopt the usually less favourable axial position.

The naphthylamine auxiliary was removed by treating with concentrated hydrochloric acid to give the dichloro complex $\left(R_{\mathrm{C}}, R_{\mathrm{P}}\right)-\mathbf{5 1}$ (Scheme 4.6). The ${ }^{31} \mathrm{P}\left\{{ }^{1} \mathrm{H}\right\}$ NMR spectrum showed a singlet peak at $\delta 46.0$.

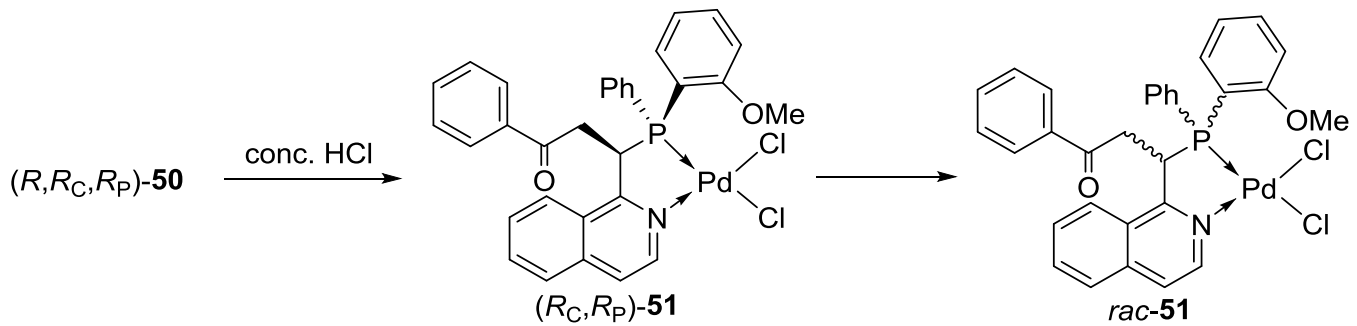

\section{Scheme 4.6}

While no suitable crystals for X-ray analysis have been obtained, the compound was found to have diminished optical activity over a period of one week, suggesting racemization of the product. ${ }^{31} \mathrm{P}\left\{{ }^{1} \mathrm{H}\right\}$ NMR of the solution after a few days showed another singlet peak at $\delta 54.4$ in addition to the $\delta 46.0$ peak, in the ratio of $1: 1$, suggesting the presence of two diastereomers in the product mixture as the result of racemization. 


\subsubsection{Catalytic asymmetric hydrophosphination with o-}

anisylphenylphosphine promoted by catalytic amount of Pd complex

The hydrophosphination reaction between enone 45 and $o$ anisylphenylphosphine was repeated with a catalytic amount of the chiral template $(R)-5$ (Scheme 4.7).
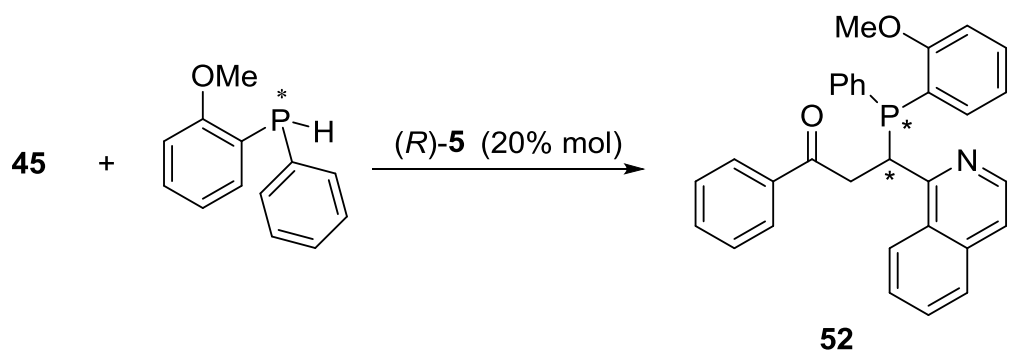

\section{Scheme 4.7}

Monitoring the reaction with ${ }^{31} \mathrm{P}\left\{{ }^{1} \mathrm{H}\right\}$ NMR, two new single peaks appeared at $\delta-6.6$ and -4.4 after 2 hours, corresponding to the formation of two pairs of disasterometric products. The reaction was completed in 3 days. The ${ }^{31} \mathrm{P}\left\{{ }^{1} \mathrm{H}\right\}$ NMR spectrum showed the two free phosphine peaks $\delta-6.6$ and -4.4 in $1: 1.7$ ratio, giving a dr of $37: 63$. The calculated yield from the NMR spectrum was $84 \%$.

The free phosphine $\mathbf{5 2}$ was coordinated to $(R)-\mathbf{4}$ for further study and manipulation (Scheme 4.8). 


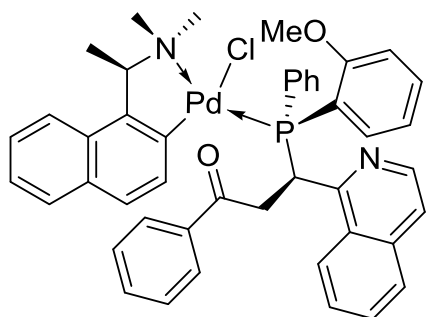

$\left(R, R_{\mathrm{C}}, R_{\mathrm{P}}\right)-53$

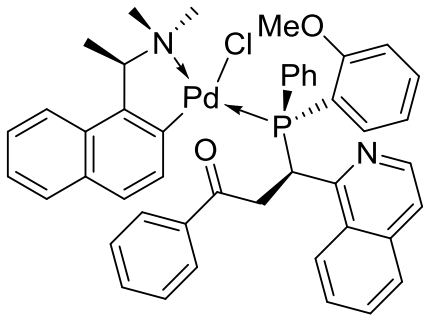

$\left(R, R_{\mathrm{C}}, S_{\mathrm{P}}\right)-53$

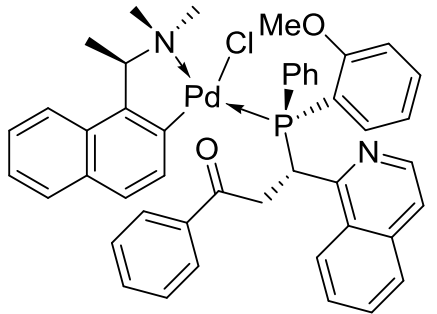

$\left(R, S_{\mathrm{C}}, S_{\mathrm{P}}\right)-53$

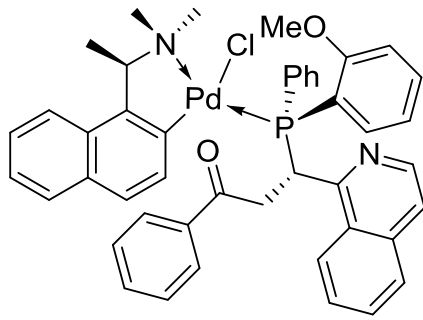

$\left(R, S_{\mathrm{C}}, R_{\mathrm{P}}\right)-53$

\section{Scheme 4.8}

Interestingly, the ${ }^{31} \mathrm{P}\left\{{ }^{1} \mathrm{H}\right\}$ NMR spectrum showed four peaks corresponding to the four isomeric products at $\delta 46.4,50.2,55.3$ and 56.4 in the ratio $1: 3.8: 10.2: 0.25$. This suggests the presence of an electron-donating group such as OMe may contribute to the stability of the ligand.

\subsection{Conclusion}

Isoquinoline-based $\mathrm{P}, \mathrm{N}$ ligands with a $\mathrm{C}$ chiral centre, as well as a $\mathrm{C}^{*_{-}}$ $\mathrm{P}^{*}$ ligand were successfully synthesized by the stoichiometric method. The predicted steric hindrance caused by $\mathrm{H}(8)$ was observed, with the $\mathrm{PhOCH}_{2}$ group forced into the axial position on the 5-membered ring. The removal of the naphthylamine template to generate the $\mathrm{P}, \mathrm{N}$ dichloro palladium complexes resulted in the racemization of the complexes. The synthesis of the P,N ligands by the catalytic method produced free phosphines which readily racemize in solution. The racemization of these $\mathrm{P}, \mathrm{N}$ ligands make them unsuitable as catalysts in asymmetric synthesis. The cause of the racemization may be due to 
a low barrier of inversion, which may be mitigated by the introduction of more $\pi$-donating functional groups to increase the barrier of inversion.

\subsection{Experimental}

Reactions involving air-sensitive materials were performed under a positive pressure of nitrogen. NMR spectra were recorded on Bruker Avance 300, 400 and 500 spectrometers. ${ }^{1} \mathrm{H}$ and ${ }^{31} \mathrm{P}\left\{{ }^{1} \mathrm{H}\right\}$ NMR chemical shifts were referenced relative to $\mathrm{SiMe}_{4}$ and $\mathrm{H}_{3} \mathrm{PO}_{4}$ respectively. Melting points were determined on SRS-Optimelt MPA-100 apparatus and were uncorrected. Optical rotations were measured on the specified solution in a $0.1 \mathrm{dm}$ cell at $25^{\circ} \mathrm{C}$ with Atago AP-300 Automatic Polarimeter. Elemental Analyses and single crystal X-ray diffraction studies were performed by the Elemental Analysis Laboratory and X-ray Diffraction Laboratory, respectively, of the Division of Chemistry and Biological Chemistry at Nanyang Technological University. The starting materials, diphenylphosphine, ${ }^{39}$ racemic $o$ anisylphenylphosphine, ${ }^{42}$ 1-isoquinolinecarbaldehyde, ${ }^{50}$ bis(acetonitrile $)\{(R)-1-[1-(N, N$-dimethylamino)ethyl]naphthyl-

$C, N\}$ palladium(II) $\quad$ perchlorate $^{28}$ and $(R, R)$-di- $\mu$-chlorobis $\{1-[1-(N, N-$ dimethylamino)ethyl]naphthyl- $C, N\}$ dipalladium(II), ${ }^{26}$ were prepared according to literature procedures.

\section{(E)-3-Isoquinoline-1-yl-1-phenyl-2-propenone, 45.}

1-isoquinolinecarbaldehyde $(1.00 \mathrm{~g}, 6.4 \mathrm{mmol})$ and acetophenone $(0.75 \mathrm{~mL}$, $0.77 \mathrm{~g}, 6.4 \mathrm{mmol})$ were dissolved in ethanol $(5 \mathrm{~mL})$, and $\mathrm{NaOH}(0.25 \mathrm{~g}, 6.4$ mmol) in water $(2.5 \mathrm{~mL})$ was added. The reaction mixture was stirred overnight at r.t., followed by the addition of water $(50 \mathrm{~mL})$. The ethanol was removed 
under reduced pressure, and dichloromethane $(50 \mathrm{~mL} \times 3)$ was used to extract the product from the aqueous layer. The organic extracts were combined, dried with $\mathrm{MgSO}_{4}$ and filtered. Removal of the solvent gave the crude product as a dark yellow solid. The product was purified by column chromatography with hexanes/dichloromethane $(5: 1, \mathrm{v} / \mathrm{v})$ as eluant to give a yellow solid (1.08 $\mathrm{g}$, 65\%). mp 146-148 ${ }^{\circ} \mathrm{C} ;{ }^{1} \mathrm{H}$ NMR $\left(500 \mathrm{MHz}, \mathrm{CDCl}_{3}\right) \delta$ 7.44-7.47 (m, 2H, aromatic), 7.52-7.61 (m, 4H, aromatic), $7.74(\mathrm{~d}, 1 \mathrm{H}, J=8.1 \mathrm{~Hz}$, aromatic), 8.12 (d, $2 \mathrm{H}, J=8.4 \mathrm{~Hz}$, aromatic), 8.27 (d, $1 \mathrm{H}, J=7.4 \mathrm{~Hz}$, aromatic), 8.35 (d, 1H, $J$ $\left.=14.9 \mathrm{~Hz}, \mathrm{H}_{\alpha}\right), 8.55(\mathrm{~d}, 1 \mathrm{H}, J=5.5 \mathrm{~Hz}$, aromatic $), 8.61\left(\mathrm{~d}, 1 \mathrm{H}, J=14.9 \mathrm{~Hz}, \mathrm{H}_{\beta}\right)$.

Synthesis of $\{(R)-1-[1-(N, N$-dimethylamino)ethyl]naphthyl- $C, N\}\{(R)-1-[1-$ (diphenylphosphino)-3-phenylpropan-3-onyl]isoquinolyl- $N, P\}$ palladium(II) perchlorate, $(R, R)-46$ and $\{(R)-1-[1-(N, N$-dimethylamino)ethyl $]$ naphthyl$C, N\}\{(S)-1-[1-($ diphenylphosphino)-3-phenylpropan-3-onyl]isoquinolyl$N, P$ \}palladium(II) perchlorate, $(\boldsymbol{R}, S)-46$. Bis(acetonitrile) complex $(R)-5$ $(0.55 \mathrm{~g}, 1.13 \mathrm{mmol})$ was added to a solution of diphenylphosphine $(0.21 \mathrm{~g}, 1.13$ mmol, 1 equiv. $)$ in dichloromethane $(5 \mathrm{~mL})$. Enone $45(0.29 \mathrm{~g}, 1.13 \mathrm{mmol})$ was added, followed by $\mathrm{Et}_{3} \mathrm{~N}(0.11 \mathrm{~g}, 1.13 \mathrm{mmol})$ in DCM $(1 \mathrm{~mL})$ dropwise. The reaction was monitored by ${ }^{31} \mathrm{P}\left\{{ }^{1} \mathrm{H}\right\}$ NMR and found to be completed overnight. The crude product was then purified by column chromatography. NMR calculated yield: $95 \% ;{ }^{31} \mathrm{P}\left\{{ }^{1} \mathrm{H}\right\} \mathrm{NMR}\left(202 \mathrm{MHz}, \mathrm{CDCl}_{3}\right) 2$ signals in ca. $2.5: 1$ ratio, $\delta 54.8(\mathrm{~s}), 58.5(\mathrm{~s}) .{ }^{31} \mathrm{P}\left\{{ }^{1} \mathrm{H}\right\} \mathrm{NMR}\left(121 \mathrm{MHz}, \mathrm{CDCl}_{3}\right) 2$ signals in ca. 2.5 : 1 ratio, $\delta 55.4(\mathrm{~s}), 59.1(\mathrm{~s})$. 
$\{(R)-1-[1-(N, N-D i m e t h y l a m i n o) e t h y l]$ naphthyl- $C, N\}\{(R)-1-[1-$

(diphenylphosphino)-3-phenylpropan-3-onyl]isoquinolyl- $N, P\}$ palladium(II)

perchlorate, $(\boldsymbol{R}, \boldsymbol{R})$-46. Recrystallization from dichloromethane-diethyl ether gives the product as white crystals $(0.45 \mathrm{~g}, 68 \%) \cdot \mathrm{mp} 207-210{ }^{\circ} \mathrm{C}(\mathrm{dec}) ;[\alpha]_{\mathrm{D}}=$ $-250^{\circ}\left(c=1, \mathrm{CH}_{2} \mathrm{Cl}_{2}\right) ;{ }^{31} \mathrm{P}\left\{{ }^{1} \mathrm{H}\right\} \mathrm{NMR}\left(121 \mathrm{MHz}, \mathrm{CDCl}_{3}\right) \delta 55.4(\mathrm{~s})$.

$\{(R)-1-[1-(N, N$-Dimethylamino)ethyl]naphthyl- $C, N\}\{(S)-1-[1-$ (diphenylphosphino)-3-phenylpropan-3-onyl]isoquinolyl- $N, P$ \}palladium(II) perchlorate, $(\boldsymbol{R}, \boldsymbol{S})-\mathbf{4 6}$. Recrystallization from ethyl acetate-diethyl ether gives the product as white crystals $(0.21 \mathrm{~g}, 75 \%) . \mathrm{mp} 217-219^{\circ} \mathrm{C}(\mathrm{dec}) ;[\alpha]_{\mathrm{D}}=+255^{\circ}$ $\left(c=1, \mathrm{CH}_{2} \mathrm{Cl}_{2}\right) ;{ }^{31} \mathrm{P}\left\{{ }^{1} \mathrm{H}\right\} \mathrm{NMR}\left(121 \mathrm{MHz}, \mathrm{CDCl}_{3}\right) \delta 59.1$ (s).

\section{Dichloro\{1-[1-(diphenylphosphino)-3-phenylpropan-3-onyl]isoquinolyl-}

$\boldsymbol{N}, \boldsymbol{P}$ \}palladium(II), 47. Conc. $\mathrm{HCl}(1 \mathrm{~mL})$ was added to $(R, R)-46(0.022 \mathrm{~g}$, $0.026 \mathrm{mmol})$ in dichloromethane $(5 \mathrm{~mL})$ and stirred for $2 \mathrm{~h}$. The reaction was quenched with water $(50 \mathrm{~mL})$. The organic layer was extracted, washed with water $(50 \mathrm{~mL} \times 2)$ and dried with anhydrous $\mathrm{MgSO}_{4}$. The product was recrystallized from dichloromethane-diethyl ether to give yellow crystals $(0.016$ g, 97\%). mp 236-238 ${ }^{\circ} \mathrm{C}(\mathrm{dec}) ;{ }^{31} \mathrm{P}\left\{{ }^{1} \mathrm{H}\right\} \mathrm{NMR}\left(202 \mathrm{MHz}, \mathrm{CDCl}_{3}\right), \delta 51.9$ (s).

[1-(1-Isoquinolyl)-3-phenylpropan-3-onyl]diphenylphosphine, 48. To a solution of diphenylphosphine $(0.055 \mathrm{~g}, 0.29 \mathrm{mmol})$ in dichloromethane $(5 \mathrm{~mL})$, (R)-5 (0.029 g, $0.058 \mathrm{mmol}, 20 \mathrm{~mol} \%)$ was added. The solution was stirred at r.t. for $5 \mathrm{~min}$ and then was cooled to $-80{ }^{\circ} \mathrm{C}$. Subsequently, the enone $45(0.078$ g, $0.3 \mathrm{mmol})$ was added. $\mathrm{Et}_{3} \mathrm{~N}(0.03 \mathrm{~g}, 0.29 \mathrm{mmol})$ in dichloromethane $(1 \mathrm{~mL})$ was added dropwise. The solution was subsequently stirred at $-80{ }^{\circ} \mathrm{C}$ and the reaction was monitored by ${ }^{31} \mathrm{P}\left\{{ }^{1} \mathrm{H}\right\}$ NMR. The reaction was found to be 
completed at $3 \mathrm{~d}$. The product was not isolated and directly used in further reactions. NMR calculated yield: $73 \% ;{ }^{31} \mathrm{P}\left\{{ }^{1} \mathrm{H}\right\}$ NMR (202 $\left.\mathrm{MHz}, \mathrm{CDCl}_{3}\right) \delta 3.0$ (s).

Coordination of 48 to $(R)-4$. Formation of chloro\{ $(R)-1-[1-(N, N-$ dimethylamino)ethyl]naphthyl- $C, N\}\{(R)-[1-(1-i s o q u i n o l y l)-3-$ phenylpropan-3-onyl]diphenylphosphine \}palladium(II), $\quad(R, R)-49, \quad$ and chloro\{(R)-1-[1-(N,N-dimethylamino)ethyl]naphthyl- $C, N\}\{(S)-[1-(1-$ isoquinolyl)-3-phenylpropan-3-onyl]diphenylphosphine\}palladium(II), (R,S)-49. (R)-4 (0.1 g, $0.145 \mathrm{mmol}, 0.5$ equiv. $)$ in dichloromethane $(5 \mathrm{~mL})$ was added to $\mathbf{4 8}$ and stirred for $30 \mathrm{~min}$. The solvent was removed under reduced pressure to give a yellow solid. ${ }^{31} \mathrm{P}\left\{{ }^{1} \mathrm{H}\right\} \mathrm{NMR}\left(202 \mathrm{MHz}, \mathrm{CDCl}_{3}\right) 2$ signals in $1: 1$ ratio, $\delta 53.0(\mathrm{~s}), 54.8(\mathrm{~s}) ;{ }^{31} \mathrm{P}\left\{{ }^{1} \mathrm{H}\right\}$ NMR $\left(121 \mathrm{MHz}, \mathrm{CDCl}_{3}\right) 2$ signals in 1 : 1 ratio, $\delta 53.5(\mathrm{~s}), 55.4(\mathrm{~s})$. 
Synthesis of $\left\{(R)-1-[1-(N, N\right.$-dimethylamino $)$ ethyl]naphthyl- $C, N\}\left\{\left(R_{\mathrm{C}}, R_{\mathrm{P}}\right)-1-\right.$ [1-((2-methoxyphenyl)phenylphosphino)-3-phenylpropan-3-

onyl]isoquinolyl- $N, P$ \}palladium(II) perchlorate, $\left(R, R_{\mathrm{C}}, R_{\mathrm{P}}\right)-50,\{(\boldsymbol{R})-1-[1-$ $\left(N, N\right.$-dimethylamino)ethyl]naphthyl-C,N\}\{( $\left.S_{\mathrm{C}}, S_{\mathrm{P}}\right)-1-[1-((2-$

methoxyphenyl)phenylphosphino)-3-phenylpropan-3-onyl]isoquinolyl$N, P\}$ palladium(II) $\quad$ perchlorate, $\quad\left(R, S_{\mathrm{C}}, S_{\mathrm{P}}\right)-50, \quad\{(R)-1-[1-(N, N-$ dimethylamino)ethyl]naphthyl-C,N\}\{($\left.R_{\mathrm{C}}, S_{\mathrm{P}}\right)-1-[1-((2-$ methoxyphenyl)phenylphosphino)-3-phenylpropan-3-onyl]isoquinolyl$N, P\}$ palladium(II) perchlorate, $\quad\left(R, R_{\mathrm{C}}, S_{\mathrm{P}}\right)-50 \quad$ and $\quad\{(R)-1-[1-(N, N-$ dimethylamino)ethyl]naphthyl-C,N\}\{($\left.S_{\mathrm{C}}, R_{\mathrm{P}}\right)-1-[1-((2-$ methoxyphenyl)phenylphosphino)-3-phenylpropan-3-onyl]isoquinolyl$N, P$ \}palladium(II) perchlorate, $\left(\boldsymbol{R}, \boldsymbol{S}_{\mathbf{C}}, \boldsymbol{R}_{\mathbf{P}}\right)-50$. Bis(acetonitrile) complex $(R)-5$ $(0.082 \mathrm{~g}, 0.31 \mathrm{mmol})$ was added to a solution of $o$-anisylphenylphosphine (0.068 g, $0.31 \mathrm{mmol}, 1$ equiv.) in dichloromethane (5 mL). Enone 45 (0.15 g, $0.31 \mathrm{mmol})$ was added, followed by $\mathrm{Et}_{3} \mathrm{~N}(0.032 \mathrm{~g}, 0.31 \mathrm{mmol})$ in DCM (1 mL) dropwise. The reaction was monitored by ${ }^{31} \mathrm{P}\left\{{ }^{1} \mathrm{H}\right\}$ NMR and found to be completed in $3 \mathrm{~d}$. The crude product was then purified by column chromatography. NMR calculated yield: 93\%; ${ }^{31} \mathrm{P}\left\{{ }^{1} \mathrm{H}\right\}$ NMR (162 MHz, $\left.\mathrm{CDCl}_{3}\right) 4$ signals in ca. $1: 3.6: 1.6: 2.1$ ratio, $\delta 46.4(\mathrm{~s}), 50.4(\mathrm{~s}), 55.6(\mathrm{~s}), 58.4$ (s).

$\left\{(R)-1-[1-(N, N\right.$-Dimethylamino $)$ ethyl] naphthyl- $C, N\}\left\{\left(R_{\mathrm{C}}, R_{\mathrm{P}}\right)-1-[1-((2-\right.$ methoxyphenyl)phenylphosphino)-3-phenylpropan-3-onyl]isoquinolyl$N, P\}$ palladium(II) perchlorate, $\quad\left(\boldsymbol{R}, \boldsymbol{R}_{\mathrm{C}}, \boldsymbol{R}_{\mathbf{P}}\right)-50 . \quad$ Recrystallization from dichloromethane-diethyl ether gives the product as white crystals $(0.104 \mathrm{~g}$, 
88\%). mp 197-200 ${ }^{\circ} \mathrm{C}(\mathrm{dec}) ;{ }^{31} \mathrm{P}\left\{{ }^{1} \mathrm{H}\right\}$ NMR (162 MHz, $\left.\mathrm{CDCl}_{3}\right) \delta 50.4$ (s), (202 $\left.\mathrm{MHz}, \mathrm{CDCl}_{3}\right) \delta 50.1(\mathrm{~s})$.

\section{Dichloro\{1-[1-((2-methoxyphenyl)phenylphosphino)-3-phenylpropan-3-} onyl]isoquinolyl- $\boldsymbol{N}, \boldsymbol{P}$ \}palladium(II), 51. Conc. $\mathrm{HCl}(1 \mathrm{~mL})$ was added to $\left(R, R_{\mathrm{C}}, R_{\mathrm{P}}\right)-\mathbf{5 0}(0.018 \mathrm{~g}, 0.02 \mathrm{mmol})$ in dichloromethane $(5 \mathrm{~mL})$ and stirred for 2 h. The reaction was quenched with water $(50 \mathrm{~mL})$. The organic layer was extracted, washed with water $(50 \mathrm{~mL}$ x 2$)$ and dried with anhydrous $\mathrm{MgSO}_{4}$. The product was purified by column chromatography to give a yellow solid $(0.013 \mathrm{~g}, 95 \%) .{ }^{31} \mathrm{P}\left\{{ }^{1} \mathrm{H}\right\} \mathrm{NMR}\left(202 \mathrm{MHz}, \mathrm{CDCl}_{3}\right), \delta 46.0$ (s).

\section{[1-(1-Isoquinolyl)-3-phenylpropan-3-onyl](2-}

methoxyphenyl)phenylphosphine, 52. To a solution of $o$ anisylphenylphosphine $(0.066 \mathrm{~g}, 0.31 \mathrm{mmol})$ in dichloromethane $(5 \mathrm{~mL}),(R)-5$ $(0.022 \mathrm{~g}, 0.046 \mathrm{mmol}, 15 \mathrm{~mol} \%)$ was added. The solution was stirred at r.t. for 5 min. Enone $45(0.088 \mathrm{~g}, 0.34 \mathrm{mmol})$ was added. $\mathrm{Et}_{3} \mathrm{~N}(0.031 \mathrm{~g}, 0.31 \mathrm{mmol})$ in dichloromethane $(1 \mathrm{~mL})$ was added dropwise. The solution was subsequently stirred at r.t. and the reaction was monitored by ${ }^{31} \mathrm{P}\left\{{ }^{1} \mathrm{H}\right\}$ NMR. The reaction was found to be completed in $24 \mathrm{~h}$. The product was not isolated and directly used in further reactions. NMR calculated yield: 84\%; ${ }^{31} \mathrm{P}\left\{{ }^{1} \mathrm{H}\right\}$ NMR $(202 \mathrm{MHz}$, $\left.\mathrm{CDCl}_{3}\right) 2$ signals in ca. $1: 1.7$ ratio, $\delta-6.6(\mathrm{~s}),-4.4(\mathrm{~s})$.

\section{Chloro $\{(R)-1-[1-(N, N$-dimethylamino)ethyl]naphthyl-C,N $\}[1-(1-$} isoquinolyl)-3-phenylpropan-3-onyl](2methoxyphenyl)phenylphosphine\}palladium(II)，(R)-53. $(R)-4 \quad(0.105 \mathrm{~g}$, $0.155 \mathrm{mmol}, 0.5$ equiv. $)$ in dichloromethane $(5 \mathrm{~mL})$ was added to $\mathbf{5 0}$ and stirred for $30 \mathrm{~min}$. The solvent was removed under reduced pressure to give a yellow 
solid. ${ }^{31} \mathrm{P}\left\{{ }^{1} \mathrm{H}\right\}$ NMR $\left(202 \mathrm{MHz}, \mathrm{CDCl}_{3}\right) 4$ signals in ca. $1: 3.8: 10.2: 0.25$ ratio, $\delta 46.4(\mathrm{~s}), 50.2(\mathrm{~s}), 55.3(\mathrm{~s}), 56.4(\mathrm{~s})$. 


\section{References}

1. Erre, G.; Enthaler, S.; Junge, K.; Gladiali, S.; Beller, M. Coord. Chem. Rev. 2008, 252, 471-491.

2. Imamoto, T.; Tamura, K.; Zhang, Z.; Horiuchi, Y.; Sugiya, M.; Yoshida, K.; Yanagisawa, A.; Gridnev, I. D. J. Am. Chem. Soc. 2012, 134, 17541769.

3. Knowles, W. S.; Sabacky, M. J.; Vineyard, B. D.; Weinkauff, D. J. J. Am. Chem. Soc. 1975, 97, 2567-2568.

4. Vineyard, B. D.; Knowles, W. S.; Sabacky, M. J.; Bachman, G. L.; Weinkauff, D. J. J. Am. Chem. Soc. 1977, 99, 5946-5952.

5. Knowles, W. S. Acc. Chem. Res. 1983, 16, 106-112.

6. Miyashita, A.; Yasuda, A.; Takaya, H.; Toriumi, K.; Ito, T.; Souchi, T.; Noyori, R. J. Am. Chem. Soc. 1980, 102, 7932-7934.

7. Takaya, H.; Mashima, K.; Koyano, K.; Yagi, M.; Kumobayashi, H.; Taketomi, T.; Akutagawa, S.; Noyori, R. J. Org. Chem. 1986, 51, 629635.

8. Noyori, R.; Takaya, H. Acc. Chem. Res. 1990, 23, 345-350.

9. Ault, A. J. Chem. Educ. 2002, 79, 572.

10. Kagan, H. B.; Dang, T.-P. J. Am. Chem. Soc. 1972, 94, 6429-6433.

11. Burk, M. J.; Feaster, J. E.; Nugent, W. A.; Harlow, R. L. J. Am. Chem. Soc. 1993, 115, 10125-10138.

12. Fryzuk, M. D.; Bosnich, B. J. Am. Chem. Soc. 1977, 99, 6262-6267.

13. Togni, A.; Breutel, C.; Schnyder, A.; Spindler, F.; Landert, H.; Tijani, A. J. Am. Chem. Soc. 1994, 116, 4062-4066.

14. Tang, W.; Zhang, X. Angew. Chem., Int. Ed. 2002, 41, 1612-1614. 
15. Liu, D.; Zhang, X. Eur. J. Org. Chem. 2005, 646-649.

16. Leung, P.-H. Acc. Chem. Res. 2004, 37, 169-177.

17. Mislow, K.; Baechler, R. D. J. Am. Chem. Soc. 1971, 93, 773-774.

18. IUPAC, Compendium of Chemical Terminology, 2nd ed. (the "Gold Book"). Compiled by A. D. McNaught and A. Wilkinson. Blackwell Scientific Publications, Oxford: 1997.

19. Koskinen, A. M. P., Chirality, Topology, and Asymmetric Synthesis. In Asymmetric Synthesis of Natural Products, John Wiley \& Sons, Ltd: 2012; pp 23-54.

20. Chen, S.; Ng, J. K.-P.; Pullarkat, S. A.; Liu, F.; Li, Y.; Leung, P.-H. Organometallics 2010, 29, 3374-3386.

21. Butti, P.; Rochat, R.; Sadow, A. D.; Togni, A. Angew. Chem., Int. Ed. 2008, $47,4878-4881$.

22. Dupont, J.; Consorti, C. S.; Spencer, J. Chem. Rev. 2005, 105, 25272572.

23. Cope, A. C.; Friedrich, E. C. J. Am. Chem. Soc. 1968, 90, 909-913.

24. Otsuka, S.; Nakamura, A.; Kano, T.; Tani, K. J. Am. Chem. Soc. 1971, 93, 4301-4303.

25. Tani, K.; Brown, L. D.; Ahmed, J.; Ibers, J. A.; Nakamura, A.; Otsuka, S.; Yokota, M. J. Am. Chem. Soc. 1977, 99, 7876-7886.

26. Allen, D. G.; McLaughlin, G. M.; Robertson, G. B.; Steffen, W. L.; Salem, G.; Wild, S. B. Inorg. Chem. 1982, 21, 1007-1014.

27. Li, Y.; Selvaratnam, S.; Vittal, J. J.; Leung, P.-H. Inorg. Chem. 2003, 42, $3229-3236$. 
28. Chooi, S. Y. M.; Leung, P.-H.; Lim, C. C.; Mok, K. F.; Quek, G. H.; Sim, K. Y.; Tan, M. K. Tetrahedron: Asymmetry 1992, 3, 529-532.

29. Huang, Y.; Pullarkat, S. A.; Li, Y.; Leung, P.-H. Chem. Commun. 2010, $46,6950-6952$.

30. Ng, J. K.-P.; Tan, G.-K.; Vittal, J. J.; Leung, P.-H. Inorg. Chem. 2003, $42,7674-7682$.

31. Huang, Y.; Chew, R. J.; Li, Y.; Pullarkat, S. A.; Leung, P.-H. Org. Lett. 2011, $13,5862-5865$.

32. Huang, Y.; Pullarkat, S. A.; Li, Y.; Leung, P.-H. Inorg. Chem. 2012, 51, $2533-2540$

33. Xu, C.; Gan, J. H. K.; Hennersdorf, F.; Li, Y.; Pullarkat, S. A.; Leung, P.-H. Organometallics 2012, 31, 3022-3026.

34. Aw, B.-H.; Leung, P.-H. Tetrahedron: Asymmetry 1994, 5, 1167-1170.

35. Aw, B.-H.; Hor, T. S. A.; Selvaratnam, S.; Mok, K. F.; White, A. J. P.; Williams, D. J.; Rees, N. H.; McFarlane, W.; Leung, P.-H. Inorg. Chem. 1997, 36, 2138-2146.

36. Song, Y.; Mok, K. F.; Leung, P.-H.; Chan, S.-H. Inorg. Chem. 1998, 37, 6399-6401.

37. Ding, Y.; Li, Y.; Pullarkat, S. A.; Yap, S. L.; Leung, P.-H. Eur. J. Inorg. Chem. 2009, 2009, 267-276.

38. Huang, Y.; Li, Y.; Leung, P.-H.; Hayashi, T. J. Am. Chem. Soc. 2014, $136,4865-4868$.

39. Gee, W.; Shaw, R. A.; Smith, B. C.; Yoke, J. T., Diphenylphosphine and Dimeric Diphenylphosphinoboranes. In Inorganic Syntheses, John Wiley \& Sons, Inc.: 2007; pp 19-24. 
40. Yap, S. L. J.; Chen, H. J.; Li, Y.; Pullarkat, S. A.; Leung, P.-H. Organometallics 2014, 33, 930-940.

41. Peer, M.; de Jong, J. C.; Kiefer, M.; Langer, T.; Rieck, H.; Schell, H.; Sennhenn, P.; Sprinz, J.; Steinhagen, H.; Wiese, B.; Helmchen, G. Tetrahedron 1996, 52, 7547-7583.

42. Togni, A.; Breutel, C.; Soares, M. C.; Zanetti, N.; Gerfin, T.; Gramlich, V.; Spindler, F.; Rihs, G. Inorg. Chim. Acta 1994, 222, 213-224.

43. Kwong, F. Y.; Chan, K. S. Organometallics 2001, 20, 2570-2578.

44. Espinet, P.; Soulantica, K. Coord. Chem. Rev. 1999, 193, 499-556.

45. Alcock, N. W.; Brown, J. M.; Hulmes, D. I. Tetrahedron: Asymmetry 1993, $4,743-756$.

46. Valk, J.-M.; Claridge, T. D. W.; Brown, J. M.; Hibbs, D.; Hursthouse, M. B. Tetrahedron: Asymmetry 1995, 6, 2597-2610.

47. Liu, F.; Pullarkat, S. A.; Li, Y.; Chen, S.; Yuan, M.; Lee, Z. Y.; Leung, P.-H. Organometallics 2009, 28, 3941-3946.

48. He, G.; Loh, S.-K.; Vittal, J. J.; Mok, K. F.; Leung, P.-H. Organometallics 1998, 17, 3931-3936.

49. Claridge, T. D. W.; Long, J. M.; Brown, J. M.; Hibbs, D.; Hursthouse, M. B. Tetrahedron 1997, 53, 4035-4050.

50. Setoguchi, M.; Iimura, S.; Sugimoto, Y.; Yoneda, Y.; Chiba, J.; Watanabe, T.; Muro, F.; Iigo, Y.; Takayama, G.; Yokoyama, M.; Taira, T.; Aonuma, M.; Takashi, T.; Nakayama, A.; Machinaga, N. Bioorg. Med. Chem. 2012, 20, 1201-1212. 


\section{Appendices}

Table A1-1 Crystal data and structure refinement for $(R, S)-12$

\begin{tabular}{|c|c|c|}
\hline Chemical formula & \multicolumn{2}{|l|}{$\mathrm{C}_{40} \mathrm{H}_{47} \mathrm{ClNPPd}$} \\
\hline Formula weight & \multicolumn{2}{|l|}{714.60} \\
\hline Temperature & \multicolumn{2}{|l|}{$103(2) \mathrm{K}$} \\
\hline Wavelength & \multicolumn{2}{|l|}{$0.71073 \AA$} \\
\hline Crystal size & \multicolumn{2}{|c|}{$0.340 \times 0.400 \times 0.420 \mathrm{~mm}$} \\
\hline Crystal habit & \multicolumn{2}{|l|}{ yellow block } \\
\hline Crystal system & \multicolumn{2}{|l|}{ orthorhombic } \\
\hline Space group & \multicolumn{2}{|l|}{ P 212121} \\
\hline \multirow[t]{3}{*}{ Unit cell dimensions } & $a=9.8837(4) \AA$ & $\alpha=90^{\circ}$ \\
\hline & $\mathrm{b}=18.2439(8) \AA$ & $\beta=90^{\circ}$ \\
\hline & $\mathrm{c}=19.3437(8) \AA$ & $\gamma=90^{\circ}$ \\
\hline Volume & \multicolumn{2}{|l|}{$3488.0(3) \AA^{3}$} \\
\hline $\mathbf{Z}$ & \multicolumn{2}{|l|}{4} \\
\hline Density (calculated) & \multicolumn{2}{|l|}{$1.361 \mathrm{~g} / \mathrm{cm}^{3}$} \\
\hline Absorption coefficient & \multicolumn{2}{|l|}{$0.683 \mathrm{~mm}^{-1}$} \\
\hline $\mathbf{F}(000)$ & \multicolumn{2}{|l|}{1488} \\
\hline Theta range for data collection & \multicolumn{2}{|l|}{2.34 to $32.03^{\circ}$} \\
\hline Reflections collected & \multicolumn{2}{|l|}{81864} \\
\hline $\begin{array}{l}\text { Coverage of independent } \\
\text { reflections }\end{array}$ & \multicolumn{2}{|l|}{$99.9 \%$} \\
\hline Absorption correction & \multicolumn{2}{|l|}{ multi-scan } \\
\hline Max. and min. transmission & \multicolumn{2}{|l|}{0.8010 and 0.7620} \\
\hline Refinement method & \multicolumn{2}{|c|}{ Full-matrix least-squares on $\mathrm{F}^{2}$} \\
\hline Refinement program & \multicolumn{2}{|c|}{ SHELXL-2013 (Sheldrick, 2013) } \\
\hline Function minimized & \multicolumn{2}{|l|}{$\Sigma \mathrm{w}\left(\mathrm{F}_{\mathrm{o}}^{2}-\mathrm{F}_{\mathrm{c}}^{2}\right)^{2}$} \\
\hline Data / restraints / parameters & \multicolumn{2}{|l|}{$12139 / 0 / 405$} \\
\hline Goodness-of-fit on $F^{2}$ & \multicolumn{2}{|l|}{1.081} \\
\hline$\Delta / \sigma_{\max }$ & \multicolumn{2}{|l|}{0.002} \\
\hline \multirow[t]{2}{*}{ Final $\mathbf{R}$ indices } & $\begin{array}{l}11409 \text { data; } \\
\mathrm{I}>2 \sigma(\mathrm{I})\end{array}$ & $\mathrm{R} 1=0.0256, w \mathrm{R} 2=0.0584$ \\
\hline & all data & $\mathrm{R} 1=0.0295, \mathrm{wR} 2=0.0602$ \\
\hline Weighting scheme & \multicolumn{2}{|c|}{$\begin{array}{l}\mathrm{w}=1 /\left[\sigma^{2}\left(\mathrm{~F}_{\mathrm{o}}^{2}\right)+(0.0279 \mathrm{P})^{2}+0.5978 \mathrm{P}\right] \\
\text { where } \mathrm{P}=\left(\mathrm{F}_{\mathrm{o}}^{2}+2 \mathrm{~F}_{\mathrm{c}}^{2}\right) / 3\end{array}$} \\
\hline Absolute structure parameter & \multicolumn{2}{|l|}{$-0.0(0)$} \\
\hline Largest diff. peak and hole & \multicolumn{2}{|c|}{0.388 and $-0.610 \mathrm{e}^{-3}$} \\
\hline R.M.S. deviation from mean & \multicolumn{2}{|l|}{$0.083 \mathrm{e}^{-3}$} \\
\hline
\end{tabular}


Table A1-2 Atomic coordinates and equivalent isotropic displacement parameters $\left(\AA^{2}\right)$ for $(R, S)-12$. $U(e q)$ is defined as one third of the trace of the orthogonalized $U_{i j}$ tensor.

\begin{tabular}{|c|c|c|c|c|}
\hline & $\mathbf{x} / \mathbf{a}$ & $y / b$ & $\mathrm{z} / \mathrm{c}$ & $\mathrm{U}(\mathbf{e q})$ \\
\hline $\mathrm{Pd} 1$ & $0.62296(2)$ & $0.31668(2)$ & $0.14131(2)$ & $0.00810(4)$ \\
\hline $\mathrm{C} 1$ & $0.6299(2)$ & $0.21014(11)$ & $0.11750(10)$ & $0.0099(4)$ \\
\hline $\mathrm{C} 2$ & $0.7356(2)$ & $0.15962(12)$ & $0.13271(11)$ & $0.0113(4)$ \\
\hline $\mathrm{C} 3$ & $0.7311(2)$ & $0.08892(12)$ & $0.10868(12)$ & $0.0124(4)$ \\
\hline $\mathrm{C} 4$ & $0.6229(3)$ & $0.06461(11)$ & $0.06602(11)$ & $0.0116(4)$ \\
\hline $\mathrm{C} 5$ & $0.6176(3)$ & $0.99143(11)$ & $0.04136(12)$ & $0.0152(4)$ \\
\hline C6 & $0.5114(3)$ & $0.96848(13)$ & $0.00067(13)$ & $0.0178(5)$ \\
\hline $\mathrm{C} 7$ & $0.4091(2)$ & $0.01790(13)$ & $0.98141(12)$ & $0.0166(5)$ \\
\hline $\mathrm{C} 8$ & $0.4132(2)$ & $0.08911(12)$ & $0.00405(12)$ & $0.0134(4)$ \\
\hline C9 & $0.5187(2)$ & $0.11491(12)$ & $0.04762(11)$ & $0.0103(4)$ \\
\hline $\mathrm{C} 10$ & $0.5246(2)$ & $0.18806(13)$ & $0.07473(11)$ & $0.0102(4)$ \\
\hline $\mathrm{C} 11$ & $0.4147(2)$ & $0.24378(12)$ & $0.06107(12)$ & $0.0104(4)$ \\
\hline $\mathrm{C} 12$ & $0.3109(3)$ & $0.24331(13)$ & $0.11967(13)$ & $0.0137(5)$ \\
\hline $\mathrm{C} 13$ & $0.5581(2)$ & $0.32018(14)$ & $0.98899(11)$ & $0.0152(4)$ \\
\hline $\mathrm{C} 14$ & $0.3847(3)$ & $0.37795(12)$ & $0.05594(12)$ & $0.0147(4)$ \\
\hline $\mathrm{C} 15$ & $0.7332(2)$ & $0.21641(11)$ & $0.28566(11)$ & $0.0113(4)$ \\
\hline $\mathrm{C} 16$ & $0.6078(2)$ & $0.18114(13)$ & $0.29086(11)$ & $0.0154(4)$ \\
\hline $\mathrm{C} 17$ & $0.5973(3)$ & $0.11332(13)$ & $0.32351(13)$ & $0.0191(5)$ \\
\hline C18 & $0.7121(3)$ & $0.07950(13)$ & $0.34984(14)$ & $0.0216(5)$ \\
\hline C19 & $0.8370(3)$ & $0.11272(14)$ & $0.34261(13)$ & $0.0206(5)$ \\
\hline $\mathrm{C} 20$ & $0.8485(2)$ & $0.18130(13)$ & $0.31072(11)$ & $0.0154(4)$ \\
\hline $\mathrm{C} 21$ & $0.9110(2)$ & $0.33703(11)$ & $0.23837(12)$ & $0.0101(4)$ \\
\hline $\mathrm{C} 22$ & $0.9537(2)$ & $0.36791(12)$ & $0.17559(12)$ & $0.0125(4)$ \\
\hline $\mathrm{C} 23$ & $0.0808(3)$ & $0.40001(13)$ & $0.16952(14)$ & $0.0169(5)$ \\
\hline $\mathrm{C} 24$ & $0.1678(2)$ & $0.40129(14)$ & $0.22568(13)$ & $0.0171(5)$ \\
\hline $\mathrm{C} 25$ & $0.1279(3)$ & $0.37018(12)$ & $0.28813(12)$ & $0.0163(4)$ \\
\hline $\mathrm{C} 26$ & $0.0005(2)$ & $0.33907(12)$ & $0.29490(12)$ & $0.0126(4)$ \\
\hline $\mathrm{C} 27$ & $0.6516(2)$ & $0.37083(11)$ & $0.30382(11)$ & $0.0098(4)$ \\
\hline $\mathrm{C} 28$ & $0.5051(2)$ & $0.34809(14)$ & $0.32013(13)$ & $0.0165(5)$ \\
\hline $\mathrm{C} 29$ & $0.7356(2)$ & $0.38884(11)$ & $0.36676(11)$ & $0.0103(4)$ \\
\hline $\mathrm{C} 30$ & $0.7397(2)$ & $0.33986(12)$ & $0.42238(12)$ & $0.0128(4)$ \\
\hline $\mathrm{C} 31$ & $0.8213(3)$ & $0.35167(13)$ & $0.47998(12)$ & $0.0156(5)$ \\
\hline $\mathrm{C} 32$ & $0.8243(3)$ & $0.29929(13)$ & $0.54169(13)$ & $0.0198(5)$ \\
\hline C33 & $0.7358(4)$ & $0.32755(18)$ & $0.59994(15)$ & $0.0373(8)$ \\
\hline C34 & $0.7867(4)$ & $0.22069(16)$ & $0.52278(17)$ & $0.0416(9)$ \\
\hline $\mathrm{C} 35$ & $0.8997(3)$ & $0.41514(13)$ & $0.48124(13)$ & $0.0178(5)$ \\
\hline $\mathrm{C} 36$ & $0.8958(3)$ & $0.46483(13)$ & $0.42644(12)$ & $0.0162(5)$ \\
\hline $\mathrm{C} 37$ & $0.8147(2)$ & $0.45309(12)$ & $0.36840(12)$ & $0.0120(4)$ \\
\hline C38 & $0.8090(2)$ & $0.50808(12)$ & $0.30891(12)$ & $0.0125(4)$ \\
\hline
\end{tabular}




\begin{tabular}{lllll}
\hline & $\mathbf{x} / \mathbf{a}$ & $\mathbf{y} / \mathbf{b}$ & $\mathbf{z} / \mathbf{c}$ & $\mathbf{U}(\mathbf{e q})$ \\
\hline C39 & $0.6766(3)$ & $0.55190(13)$ & $0.31184(14)$ & $0.0179(5)$ \\
C40 & $0.9297(3)$ & $0.56040(14)$ & $0.30612(14)$ & $0.0216(5)$ \\
C11 & $0.62258(6)$ & $0.44860(3)$ & $0.14677(3)$ & $0.01572(10)$ \\
N1 & $0.48496(18)$ & $0.31709(11)$ & $0.05556(9)$ & $0.0100(3)$ \\
P1 & $0.73583(6)$ & $0.30586(3)$ & $0.24260(3)$ & $0.00821(10)$ \\
\hline
\end{tabular}


Table A2-1 Crystal data and structure refinement for $(S)-18$

\begin{tabular}{|c|c|c|}
\hline Chemical formula & \multicolumn{2}{|l|}{$\mathrm{C}_{52} \mathrm{H}_{57} \mathrm{ClO}_{1.50} \mathrm{P}_{3} \mathrm{Pd}$} \\
\hline Formula weight & \multicolumn{2}{|l|}{940.73} \\
\hline Temperature & \multicolumn{2}{|l|}{$103(2) \mathrm{K}$} \\
\hline Wavelength & \multicolumn{2}{|l|}{$0.71073 \AA$} \\
\hline Crystal size & \multicolumn{2}{|c|}{$0.120 \times 0.180 \times 0.320 \mathrm{~mm}$} \\
\hline Crystal habit & \multicolumn{2}{|l|}{ colorless block } \\
\hline Crystal system & \multicolumn{2}{|l|}{ monoclinic } \\
\hline Space group & \multicolumn{2}{|l|}{ P 1211} \\
\hline \multirow[t]{3}{*}{ Unit cell dimensions } & $a=10.7690(6) \AA$ & $\alpha=90^{\circ}$ \\
\hline & $\mathrm{b}=11.1444(6) \AA$ & $\beta=104.6581(19)^{\circ}$ \\
\hline & $c=20.4571(11) \AA$ & $\gamma=90^{\circ}$ \\
\hline Volume & \multicolumn{2}{|l|}{$2375.2(2) \AA^{3}$} \\
\hline $\mathbf{Z}$ & \multicolumn{2}{|l|}{2} \\
\hline Density (calculated) & \multicolumn{2}{|l|}{$1.315 \mathrm{~g} / \mathrm{cm}^{3}$} \\
\hline Absorption coefficient & \multicolumn{2}{|l|}{$0.585 \mathrm{~mm}^{-1}$} \\
\hline $\mathbf{F}(000)$ & \multicolumn{2}{|l|}{978} \\
\hline Theta range for data collection & \multicolumn{2}{|l|}{3.04 to $31.05^{\circ}$} \\
\hline Index ranges & \multicolumn{2}{|c|}{$-15<=\mathrm{h}<=15,-16<=\mathrm{k}<=16,-29<=1<=25$} \\
\hline Reflections collected & \multicolumn{2}{|l|}{46805} \\
\hline Independent reflections & \multicolumn{2}{|c|}{$15170[\mathrm{R}(\mathrm{int})=0.0801]$} \\
\hline Coverage of independent reflections & \multicolumn{2}{|l|}{$99.8 \%$} \\
\hline Absorption correction & \multicolumn{2}{|l|}{ multi-scan } \\
\hline Max. and min. transmission & \multicolumn{2}{|l|}{0.9330 and 0.8350} \\
\hline Refinement method & \multicolumn{2}{|c|}{ Full-matrix least-squares on $\mathrm{F}^{2}$} \\
\hline Refinement program & \multicolumn{2}{|c|}{ SHELXL-2013 (Sheldrick, 2013) } \\
\hline Function minimized & \multicolumn{2}{|l|}{$\Sigma \mathrm{w}\left(\mathrm{F}_{\mathrm{o}}^{2}-\mathrm{F}_{\mathrm{c}}^{2}\right)^{2}$} \\
\hline Data / restraints / parameters & \multicolumn{2}{|l|}{$15170 / 218 / 600$} \\
\hline Goodness-of-fit on $\mathrm{F}^{2}$ & \multicolumn{2}{|l|}{0.992} \\
\hline$\Delta / \sigma_{\max }$ & \multicolumn{2}{|l|}{0.001} \\
\hline \multirow[t]{2}{*}{ Final $R$ indices } & 11870 data; $\mathrm{I}>2 \sigma(\mathrm{I})$ & $\mathrm{R} 1=0.0503, \mathrm{wR} 2=0.0768$ \\
\hline & all data & $\mathrm{R} 1=0.0764, \mathrm{wR} 2=0.0865$ \\
\hline Weighting scheme & \multicolumn{2}{|c|}{$\begin{array}{l}\mathrm{w}=1 /\left[\sigma^{2}\left(\mathrm{~F}_{\mathrm{o}}^{2}\right)+(0.0235 \mathrm{P})^{2}\right] \\
\text { where } \mathrm{P}=\left(\mathrm{F}_{\mathrm{o}}^{2}+2 \mathrm{~F}_{\mathrm{c}}^{2}\right) / 3\end{array}$} \\
\hline Absolute structure parameter & \multicolumn{2}{|l|}{$-0.0(0)$} \\
\hline Largest diff. peak and hole & 0.624 and $-0.764 \mathrm{e} \AA$ & \\
\hline R.M.S. deviation from mean & $0.104 \mathrm{e}^{-3}$ & \\
\hline
\end{tabular}


Table A2-2 Atomic coordinates and equivalent isotropic displacement parameters $\left(\AA^{2}\right)$ for $(S)-18$. $U(\mathrm{eq})$ is defined as one third of the trace of the orthogonalized $U_{\mathrm{ij}}$ tensor.

\begin{tabular}{|c|c|c|c|c|}
\hline & $\mathbf{x} / \mathbf{a}$ & $y / b$ & $\mathrm{z} / \mathrm{c}$ & $\mathrm{U}(\mathbf{e q})$ \\
\hline $\mathrm{Pd} 1$ & $0.82197(3)$ & $0.38148(3)$ & $0.24951(2)$ & $0.01181(7)$ \\
\hline $\mathrm{C} 1$ & $0.7490(4)$ & $0.3331(4)$ & $0.1488(2)$ & $0.0162(10)$ \\
\hline $\mathrm{C} 2$ & $0.6164(4)$ & $0.3362(4)$ & $0.1180(2)$ & $0.0174(10)$ \\
\hline $\mathrm{C} 3$ & $0.5243(4)$ & $0.3971(5)$ & $0.1523(2)$ & $0.0186(10)$ \\
\hline $\mathrm{C} 4$ & $0.5172(5)$ & $0.5309(4)$ & $0.1314(2)$ & $0.0228(11)$ \\
\hline $\mathrm{C} 5$ & $0.3883(4)$ & $0.3454(4)$ & $0.1364(2)$ & $0.0237(11)$ \\
\hline C6 & $0.5751(5)$ & $0.2935(4)$ & $0.0515(2)$ & $0.0219(11)$ \\
\hline $\mathrm{C} 7$ & $0.6598(5)$ & $0.2521(4)$ & $0.0168(2)$ & $0.0238(11)$ \\
\hline $\mathrm{C} 8$ & $0.7917(5)$ & $0.2598(4)$ & $0.0433(2)$ & $0.0188(10)$ \\
\hline C9 & $0.8821(5)$ & $0.2214(4)$ & $0.0011(2)$ & $0.0203(10)$ \\
\hline $\mathrm{C} 10$ & $0.8665(5)$ & $0.3006(5)$ & $0.9381(3)$ & $0.0318(13)$ \\
\hline $\mathrm{C} 11$ & $0.8637(5)$ & $0.0895(4)$ & $0.9816(3)$ & $0.0309(13)$ \\
\hline $\mathrm{C} 12$ & $0.8343(4)$ & $0.3051(4)$ & $0.1091(2)$ & $0.0148(9)$ \\
\hline $\mathrm{C} 13$ & $0.9745(4)$ & $0.3396(4)$ & $0.1388(2)$ & $0.0155(9)$ \\
\hline $\mathrm{C} 14$ & $0.0559(5)$ & $0.2351(4)$ & $0.1743(2)$ & $0.0218(11)$ \\
\hline $\mathrm{C} 15$ & $0.8975(4)$ & $0.5957(4)$ & $0.1451(2)$ & $0.0161(10)$ \\
\hline $\mathrm{C} 16$ & $0.8984(4)$ & $0.7056(4)$ & $0.1778(2)$ & $0.0197(10)$ \\
\hline $\mathrm{C} 17$ & $0.8388(5)$ & $0.8055(4)$ & $0.1428(3)$ & $0.0268(12)$ \\
\hline $\mathrm{C} 18$ & $0.7789(5)$ & $0.7960(5)$ & $0.0745(3)$ & $0.0302(13)$ \\
\hline C19 & $0.7781(5)$ & $0.6879(5)$ & $0.0418(3)$ & $0.0290(12)$ \\
\hline $\mathrm{C} 20$ & $0.8362(5)$ & $0.5872(4)$ & $0.0761(2)$ & $0.0212(11)$ \\
\hline $\mathrm{C} 21$ & $0.1243(4)$ & $0.5034(4)$ & $0.2404(2)$ & $0.0136(9)$ \\
\hline $\mathrm{C} 22$ & $0.1910(4)$ & $0.6000(4)$ & $0.2215(2)$ & $0.0179(10)$ \\
\hline $\mathrm{C} 23$ & $0.3181(5)$ & $0.6199(4)$ & $0.2544(3)$ & $0.0234(11)$ \\
\hline $\mathrm{C} 24$ & $0.3822(5)$ & $0.5419(4)$ & $0.3043(2)$ & $0.0212(11)$ \\
\hline $\mathrm{C} 25$ & $0.3184(4)$ & $0.4452(4)$ & $0.3236(2)$ & $0.0185(10)$ \\
\hline $\mathrm{C} 26$ & $0.1906(4)$ & $0.4275(4)$ & $0.2916(2)$ & $0.0161(10)$ \\
\hline $\mathrm{C} 27$ & $0.7602(4)$ & $0.5885(4)$ & $0.3540(2)$ & $0.0159(10)$ \\
\hline $\mathrm{C} 28$ & $0.7145(4)$ & $0.6447(4)$ & $0.2918(2)$ & $0.0177(10)$ \\
\hline $\mathrm{C} 29$ & $0.6334(5)$ & $0.7435(4)$ & $0.2856(3)$ & $0.0232(11)$ \\
\hline $\mathrm{C} 30$ & $0.5941(5)$ & $0.7831(4)$ & $0.3411(3)$ & $0.0276(12)$ \\
\hline $\mathrm{C} 31$ & $0.6364(5)$ & $0.7271(4)$ & $0.4027(3)$ & $0.0318(13)$ \\
\hline $\mathrm{C} 32$ & $0.7213(5)$ & $0.6308(4)$ & $0.4099(3)$ & $0.0257(12)$ \\
\hline $\mathrm{C} 33$ & $0.0227(5)$ & $0.5104(4)$ & $0.4056(2)$ & $0.0198(10)$ \\
\hline $\mathrm{C} 34$ & $0.0656(5)$ & $0.6208(4)$ & $0.3878(3)$ & $0.0267(12)$ \\
\hline $\mathrm{C} 35$ & $0.1899(5)$ & $0.6599(5)$ & $0.4183(3)$ & $0.0323(14)$ \\
\hline $\mathrm{C} 36$ & $0.2711(5)$ & $0.5907(5)$ & $0.4659(3)$ & $0.0339(14)$ \\
\hline $\mathrm{C} 37$ & $0.2292(5)$ & $0.4815(6)$ & $0.4829(3)$ & $0.0483(18)$ \\
\hline C38 & $0.1058(5)$ & $0.4410(5)$ & $0.4531(3)$ & $0.0368(15)$ \\
\hline C39 & $0.8089(4)$ & $0.3535(4)$ & $0.4147(2)$ & $0.0202(11)$ \\
\hline $\mathrm{C} 40$ & $0.6903(5)$ & $0.2872(4)$ & $0.3733(2)$ & $0.0212(11)$ \\
\hline
\end{tabular}




\begin{tabular}{lllll}
\hline & $\mathbf{x} / \mathbf{a}$ & $\mathbf{y} / \mathbf{b}$ & $\mathbf{z} / \mathbf{c}$ & $\mathbf{U}(\mathbf{e q})$ \\
\hline C41 & $0.5878(15)$ & $0.1404(18)$ & $0.2550(9)$ & $0.016(3)$ \\
C42 & $0.5915(16)$ & $0.0800(18)$ & $0.1965(9)$ & $0.023(3)$ \\
C43 & $0.4880(16)$ & $0.0093(13)$ & $0.1629(8)$ & $0.025(3)$ \\
C44 & $0.3827(13)$ & $0.0016(13)$ & $0.1902(11)$ & $0.030(3)$ \\
C45 & $0.3771(13)$ & $0.0601(15)$ & $0.2481(11)$ & $0.031(3)$ \\
C46 & $0.4817(15)$ & $0.1313(18)$ & $0.2811(10)$ & $0.022(2)$ \\
C41A & $0.599(3)$ & $0.138(3)$ & $0.2451(17)$ & $0.024(6)$ \\
C42A & $0.615(3)$ & $0.084(3)$ & $0.1865(17)$ & $0.023(5)$ \\
C43A & $0.518(3)$ & $0.013(2)$ & $0.1475(15)$ & $0.034(5)$ \\
C44A & $0.404(2)$ & $0.9958(19)$ & $0.1670(18)$ & $0.035(6)$ \\
C45A & $0.388(2)$ & $0.050(2)$ & $0.2256(18)$ & $0.034(5)$ \\
C46A & $0.485(3)$ & $0.121(3)$ & $0.2646(16)$ & $0.032(6)$ \\
C47 & $0.8533(4)$ & $0.1199(4)$ & $0.3303(2)$ & $0.0191(10)$ \\
C48 & $0.9821(5)$ & $0.1541(4)$ & $0.3462(3)$ & $0.0259(12)$ \\
C49 & $0.0783(5)$ & $0.0760(5)$ & $0.3788(3)$ & $0.0305(13)$ \\
C50 & $0.0448(5)$ & $0.9609(5)$ & $0.3940(3)$ & $0.0344(14)$ \\
C51 & $0.9178(5)$ & $0.9258(5)$ & $0.3775(3)$ & $0.0376(15)$ \\
C52 & $0.8229(5)$ & $0.0042(4)$ & $0.3463(3)$ & $0.0301(13)$ \\
C11 & $0.41408(12)$ & $0.18761(11)$ & $0.43586(6)$ & $0.0272(3)$ \\
O1 & $0.627(2)$ & $0.408(2)$ & $0.5288(14)$ & $0.024(4)$ \\
O1A & $0.602(3)$ & $0.3991(19)$ & $0.5057(19)$ & $0.055(5)$ \\
O2 & $0.6606(12)$ & $0.4325(10)$ & $0.6380(7)$ & $0.024(4)$ \\
O3 & $0.8855(14)$ & $0.3990(16)$ & $0.7437(7)$ & $0.039(5)$ \\
P1 & $0.96202(11)$ & $0.46542(10)$ & $0.19622(6)$ & $0.0128(2)$ \\
P2 & $0.86581(12)$ & $0.45922(10)$ & $0.35962(6)$ & $0.0142(2)$ \\
P3 & $0.72705(12)$ & $0.22938(10)$ & $0.29671(6)$ & $0.0162(3)$ \\
\hline & & & &
\end{tabular}


Table A3-1 Crystal data and structure refinement for 24

\begin{tabular}{|c|c|c|}
\hline Chemical formula & \multicolumn{2}{|l|}{$\mathrm{C}_{38} \mathrm{H}_{27} \mathrm{O}_{2} \mathrm{PS}$} \\
\hline Formula weight & \multicolumn{2}{|l|}{$578.62 \mathrm{~g} / \mathrm{mol}$} \\
\hline Temperature & \multicolumn{2}{|l|}{$153(2) \mathrm{K}$} \\
\hline Wavelength & \multicolumn{2}{|l|}{$0.71073 \AA$} \\
\hline Crystal size & \multicolumn{2}{|c|}{$0.400 \times 0.410 \times 0.420 \mathrm{~mm}$} \\
\hline Crystal habit & \multicolumn{2}{|l|}{ colorless block } \\
\hline Crystal system & \multicolumn{2}{|l|}{ triclinic } \\
\hline Space group & \multicolumn{2}{|l|}{$\mathrm{P}-1$} \\
\hline \multirow[t]{3}{*}{ Unit cell dimensions } & $\mathrm{a}=11.2623(4) \AA$ & $\alpha=91.346(3)^{\circ}$ \\
\hline & $\mathrm{b}=11.3502(5) \AA$ & $\beta=111.966(2)^{\circ}$ \\
\hline & $c=12.3959(5) \AA$ & $\gamma=104.270(2)^{\circ}$ \\
\hline Volume & \multicolumn{2}{|l|}{$1412.34(10) \AA^{3}$} \\
\hline $\mathbf{Z}$ & \multicolumn{2}{|l|}{2} \\
\hline Density (calculated) & \multicolumn{2}{|l|}{$1.361 \mathrm{~g} / \mathrm{cm}^{3}$} \\
\hline Absorption coefficient & \multicolumn{2}{|l|}{$0.207 \mathrm{~mm}^{-1}$} \\
\hline $\mathbf{F}(\mathbf{0 0 0})$ & \multicolumn{2}{|l|}{604} \\
\hline Theta range for data collection & \multicolumn{2}{|l|}{3.03 to $31.11^{\circ}$} \\
\hline Index ranges & \multicolumn{2}{|c|}{$-16<=\mathrm{h}<=16,-16<=\mathrm{k}<=16,-17<=1<=17$} \\
\hline Reflections collected & \multicolumn{2}{|l|}{44486} \\
\hline Independent reflections & \multicolumn{2}{|c|}{$9054[\mathrm{R}(\mathrm{int})=0.0736]$} \\
\hline Coverage of independent reflections & \multicolumn{2}{|l|}{$99.7 \%$} \\
\hline Absorption correction & \multicolumn{2}{|l|}{ multi-scan } \\
\hline Max. and min. transmission & \multicolumn{2}{|l|}{0.9220 and 0.9180} \\
\hline Refinement method & \multicolumn{2}{|c|}{ Full-matrix least-squares on $\mathrm{F}^{2}$} \\
\hline Refinement program & \multicolumn{2}{|c|}{ SHELXL-2014/7 (Sheldrick, 2014) } \\
\hline Function minimized & \multicolumn{2}{|l|}{$\Sigma \mathrm{w}\left(\mathrm{F}_{\mathrm{o}}^{2}-\mathrm{F}_{\mathrm{c}}^{2}\right)^{2}$} \\
\hline Data / restraints / parameters & \multicolumn{2}{|l|}{9054 / 0 / 380} \\
\hline Goodness-of-fit on $F^{2}$ & \multicolumn{2}{|l|}{1.022} \\
\hline \multirow[t]{2}{*}{ Final $\mathbf{R}$ indices } & 6104 data; $\mathrm{I}>2 \sigma(\mathrm{I})$ & $\mathrm{R} 1=0.0524, w \mathrm{R} 2=0.1205$ \\
\hline & all data & $\mathrm{R} 1=0.0925, \mathrm{wR} 2=0.1456$ \\
\hline Weighting scheme & \multicolumn{2}{|c|}{$\begin{array}{l}\mathrm{w}=1 /\left[\sigma^{2}\left(\mathrm{~F}_{\mathrm{o}}^{2}\right)+(0.0614 \mathrm{P})^{2}+0.8455 \mathrm{P}\right] \\
\text { where } \mathrm{P}=\left(\mathrm{F}_{\mathrm{o}}^{2}+2 \mathrm{~F}_{\mathrm{c}}^{2}\right) / 3\end{array}$} \\
\hline Largest diff. peak and hole & \multicolumn{2}{|c|}{0.633 and $-0.434 \mathrm{e}^{-3}$} \\
\hline R.M.S. deviation from mean & \multicolumn{2}{|c|}{$0.075 \mathrm{e}^{-3}$} \\
\hline
\end{tabular}


Table A3-2 Atomic coordinates and equivalent isotropic displacement parameters $\left(\AA^{2}\right)$ for 24 . U(eq) is defined as one third of the trace of the orthogonalized $\mathrm{U}_{\mathrm{ij}}$ tensor.

\begin{tabular}{|c|c|c|c|c|}
\hline & $\mathbf{x} / \mathbf{a}$ & $y / b$ & $\mathrm{z} / \mathrm{c}$ & $\mathrm{U}(\mathbf{e q})$ \\
\hline$\overline{\mathrm{C} 1}$ & $0.23312(17)$ & $0.81756(17)$ & $0.20380(16)$ & $0.0167(3)$ \\
\hline $\mathrm{C} 2$ & $0.33691(17)$ & $0.93055(17)$ & $0.22288(16)$ & $0.0169(3)$ \\
\hline $\mathrm{C} 3$ & $0.34746(19)$ & $0.03829(17)$ & $0.28871(17)$ & $0.0197(4)$ \\
\hline $\mathrm{C} 4$ & $0.4465(2)$ & $0.14397(19)$ & $0.30468(18)$ & $0.0242(4)$ \\
\hline $\mathrm{C} 5$ & $0.5389(2)$ & $0.1462(2)$ & $0.2545(2)$ & $0.0298(5)$ \\
\hline C6 & $0.5328(2)$ & $0.0431(2)$ & $0.1916(2)$ & $0.0292(5)$ \\
\hline $\mathrm{C} 7$ & $0.43306(19)$ & $0.93275(19)$ & $0.17377(17)$ & $0.0209(4)$ \\
\hline $\mathrm{C} 8$ & $0.42887(19)$ & $0.82279(19)$ & $0.10831(17)$ & $0.0215(4)$ \\
\hline C9 & $0.5250(2)$ & $0.8170(2)$ & $0.0625(2)$ & $0.0339(5)$ \\
\hline $\mathrm{C} 10$ & $0.5148(2)$ & $0.7123(2)$ & $0.9982(2)$ & $0.0370(5)$ \\
\hline $\mathrm{C} 11$ & $0.4090(2)$ & $0.6083(2)$ & $0.9766(2)$ & $0.0331(5)$ \\
\hline $\mathrm{C} 12$ & $0.3168(2)$ & $0.6097(2)$ & $0.0236(2)$ & $0.0299(5)$ \\
\hline $\mathrm{C} 13$ & $0.32491(19)$ & $0.71626(19)$ & $0.08967(17)$ & $0.0219(4)$ \\
\hline $\mathrm{C} 14$ & $0.22896(19)$ & $0.71636(18)$ & $0.13960(18)$ & $0.0218(4)$ \\
\hline $\mathrm{C} 15$ & $0.01869(18)$ & $0.91058(17)$ & $0.22452(19)$ & $0.0211(4)$ \\
\hline $\mathrm{C} 16$ & $0.0042(2)$ & $0.9886(2)$ & $0.3044(2)$ & $0.0318(5)$ \\
\hline $\mathrm{C} 17$ & $0.9237(2)$ & $0.0675(2)$ & $0.2631(3)$ & $0.0450(7)$ \\
\hline $\mathrm{C} 18$ & $0.8599(2)$ & $0.0690(2)$ & $0.1440(3)$ & $0.0458(7)$ \\
\hline C19 & $0.8729(2)$ & $0.9908(3)$ & $0.0660(3)$ & $0.0419(6)$ \\
\hline $\mathrm{C} 20$ & $0.9527(2)$ & $0.9119(2)$ & $0.1055(2)$ & $0.0307(5)$ \\
\hline $\mathrm{C} 21$ & $0.93359(17)$ & $0.60085(16)$ & $0.25871(15)$ & $0.0155(3)$ \\
\hline $\mathrm{C} 22$ & $0.95024(17)$ & $0.48670(16)$ & $0.28943(15)$ & $0.0159(3)$ \\
\hline $\mathrm{C} 23$ & $0.87373(19)$ & $0.42540(17)$ & $0.34757(16)$ & $0.0185(4)$ \\
\hline $\mathrm{C} 24$ & $0.78257(18)$ & $0.47342(16)$ & $0.37248(16)$ & $0.0177(3)$ \\
\hline $\mathrm{C} 25$ & $0.76203(17)$ & $0.58517(16)$ & $0.33597(16)$ & $0.0166(3)$ \\
\hline $\mathrm{C} 26$ & $0.83948(17)$ & $0.64733(16)$ & $0.27823(16)$ & $0.0170(3)$ \\
\hline $\mathrm{C} 27$ & $0.66952(18)$ & $0.64368(17)$ & $0.36168(16)$ & $0.0180(3)$ \\
\hline $\mathrm{C} 28$ & $0.5454(2)$ & $0.5760(2)$ & $0.35655(19)$ & $0.0262(4)$ \\
\hline $\mathrm{C} 29$ & $0.4625(2)$ & $0.6345(2)$ & $0.3824(2)$ & $0.0315(5)$ \\
\hline $\mathrm{C} 30$ & $0.5022(2)$ & $0.7598(2)$ & $0.41277(18)$ & $0.0285(5)$ \\
\hline $\mathrm{C} 31$ & $0.6236(2)$ & $0.8283(2)$ & $0.41747(18)$ & $0.0270(4)$ \\
\hline $\mathrm{C} 32$ & $0.7078(2)$ & $0.77062(19)$ & $0.39254(17)$ & $0.0224(4)$ \\
\hline C33 & $0.03929(18)$ & $0.42739(16)$ & $0.25846(16)$ & $0.0173(3)$ \\
\hline C34 & $0.12544(19)$ & $0.37394(18)$ & $0.34064(17)$ & $0.0220(4)$ \\
\hline $\mathrm{C} 35$ & $0.2046(2)$ & $0.3147(2)$ & $0.31007(19)$ & $0.0276(4)$ \\
\hline $\mathrm{C} 36$ & $0.1963(2)$ & $0.3062(2)$ & $0.1956(2)$ & $0.0286(5)$ \\
\hline C37 & $0.1095(2)$ & $0.3577(2)$ & $0.11244(19)$ & $0.0269(4)$ \\
\hline C38 & $0.0323(2)$ & $0.41843(18)$ & $0.14385(17)$ & $0.0227(4)$ \\
\hline $\mathrm{O} 1$ & $0.01486(12)$ & $0.67103(12)$ & $0.20717(11)$ & $0.0176(3)$ \\
\hline
\end{tabular}




\begin{tabular}{lllll}
\hline & $\mathbf{x} / \mathbf{a}$ & $\mathbf{y} / \mathbf{b}$ & $\mathbf{z} / \mathbf{c}$ & $\mathbf{U}(\mathbf{e q})$ \\
\hline $\mathrm{O} 2$ & $0.71184(15)$ & $0.41361(13)$ & $0.43304(14)$ & $0.0254(3)$ \\
P1 & $0.11632(5)$ & $0.80281(4)$ & $0.27436(4)$ & $0.01615(11)$ \\
S1 & $0.19294(5)$ & $0.81594(5)$ & $0.44422(4)$ & $0.02355(12)$ \\
\hline
\end{tabular}


Table A4-1 Crystal data and structure refinement for $(R, S)-30$

\begin{tabular}{|c|c|c|}
\hline Empirical formula & \multicolumn{2}{|c|}{$\mathrm{C}_{47} \mathrm{H}_{44} \mathrm{C}_{16} \mathrm{~N}$ O P Pd } \\
\hline Formula weight & \multicolumn{2}{|l|}{988.9} \\
\hline Temperature & \multicolumn{2}{|l|}{$103(2) \mathrm{K}$} \\
\hline Wavelength & \multicolumn{2}{|l|}{$0.71073 \AA$} \\
\hline Crystal system & \multicolumn{2}{|l|}{ Orthorhombic } \\
\hline Space group & \multicolumn{2}{|l|}{$\mathrm{P} 2(1) 2(1) 2(1)$} \\
\hline \multirow[t]{3}{*}{ Unit cell dimensions } & $a=9.9217(3) \AA$ & $\alpha=90^{\circ}$ \\
\hline & $b=17.8163(7) \AA$ & $\beta=90^{\circ}$ \\
\hline & $\mathrm{c}=24.6478(9) \AA$ & $\gamma=90^{\circ}$ \\
\hline Volume & \multicolumn{2}{|l|}{$4356.9(3) \AA^{3}$} \\
\hline $\mathbf{Z}$ & \multicolumn{2}{|l|}{4} \\
\hline Density (calculated) & \multicolumn{2}{|l|}{$1.508 \mathrm{Mg} / \mathrm{m}^{3}$} \\
\hline Absorption coefficient & \multicolumn{2}{|l|}{$0.868 \mathrm{~mm}^{-1}$} \\
\hline $\mathbf{F}(\mathbf{0 0 0})$ & \multicolumn{2}{|l|}{2016} \\
\hline Crystal size & \multicolumn{2}{|c|}{$0.40 \times 0.32 \times 0.22 \mathrm{~mm}^{3}$} \\
\hline Theta range for data collection & \multicolumn{2}{|l|}{1.41 to $31.10^{\circ}$} \\
\hline Index ranges & \multicolumn{2}{|c|}{$-13<=\mathrm{h}<=14,-20<=\mathrm{k}<=25,-35<=1<=35$} \\
\hline Reflections collected & \multicolumn{2}{|l|}{45943} \\
\hline Independent reflections & \multicolumn{2}{|c|}{$13860[\mathrm{R}(\mathrm{int})=0.0557]$} \\
\hline Completeness to theta $=31.10^{\circ}$ & \multicolumn{2}{|l|}{$99.2 \%$} \\
\hline Absorption correction & \multicolumn{2}{|c|}{ Semi-empirical from equivalents } \\
\hline Max. and min. transmission & \multicolumn{2}{|l|}{0.8319 and 0.7227} \\
\hline Refinement method & \multicolumn{2}{|c|}{ Full-matrix least-squares on $\mathrm{F}^{2}$} \\
\hline Data / restraints / parameters & \multicolumn{2}{|l|}{$13860 / 620 / 608$} \\
\hline Goodness-of-fit on $\mathbf{F}^{2}$ & \multicolumn{2}{|l|}{1.099} \\
\hline Final $R$ indices $[\mathbf{I}>\mathbf{2 \sigma}(\mathrm{I})]$ & \multicolumn{2}{|c|}{$\mathrm{R} 1=0.0396, \mathrm{wR} 2=0.0894$} \\
\hline $\mathbf{R}$ indices (all data) & \multicolumn{2}{|c|}{$\mathrm{R} 1=0.0538, \mathrm{wR} 2=0.1135$} \\
\hline Absolute structure parameter & \multicolumn{2}{|l|}{$-0.03(2)$} \\
\hline Largest diff. peak and hole & \multicolumn{2}{|c|}{0.743 and -0.816 e..$\AA^{-3}$} \\
\hline
\end{tabular}


Table A4-2 Atomic coordinates $\left(\begin{array}{ll}x & 1^{4}\end{array}\right)$ and equivalent isotropic displacement parameters $\left(\AA^{2} \times 10^{3}\right)$ for $(R, S)-30$. $U(e q)$ is defined as one third of the trace of the orthogonalized $U_{i j}$ tensor.

\begin{tabular}{|c|c|c|c|c|}
\hline & $\mathbf{x}$ & $\mathbf{y}$ & $\mathbf{z}$ & $\mathrm{U}(\mathbf{e q})$ \\
\hline $\operatorname{Pd}(1)$ & $4200(1)$ & $9985(1)$ & $3317(1)$ & $10(1)$ \\
\hline $\mathrm{C}(1)$ & $5242(3)$ & $10442(2)$ & $3927(1)$ & $12(1)$ \\
\hline$C(2)$ & $4827(3)$ & $10488(2)$ & $4480(1)$ & $12(1)$ \\
\hline$C(3)$ & $5501(3)$ & 10923(2) & $4847(1)$ & $14(1)$ \\
\hline $\mathrm{C}(4)$ & 6654(3) & $11348(2)$ & 4689(1) & $14(1)$ \\
\hline$C(5)$ & 7381(3) & $11784(2)$ & $5066(1)$ & $19(1)$ \\
\hline$C(6)$ & $8471(3)$ & $12194(2)$ & 4914(1) & $21(1)$ \\
\hline$C(7)$ & $8883(3)$ & $12192(2)$ & 4364(1) & $19(1)$ \\
\hline $\mathrm{C}(8)$ & $8211(3)$ & $11772(2)$ & 3988(1) & $16(1)$ \\
\hline $\mathrm{C}(9)$ & 7066(3) & $11330(2)$ & 4132(1) & $12(1)$ \\
\hline $\mathrm{C}(10)$ & $6345(3)$ & $10867(2)$ & 3762(1) & $13(1)$ \\
\hline $\mathrm{C}(11)$ & $6749(3)$ & $10800(2)$ & $3173(1)$ & $12(1)$ \\
\hline $\mathrm{C}(12)$ & $7699(3)$ & $10133(2)$ & 3095(1) & $19(1)$ \\
\hline $\mathrm{C}(13)$ & $5709(3)$ & $10466(2)$ & $2290(1)$ & $19(1)$ \\
\hline $\mathrm{C}(14)$ & 4797(3) & $11475(2)$ & $2828(1)$ & $19(1)$ \\
\hline$C(15)$ & 3084(3) & $8145(2)$ & $3464(1)$ & $13(1)$ \\
\hline$C(16)$ & $4514(8)$ & $7900(5)$ & $3319(4)$ & $13(2)$ \\
\hline $\mathrm{C}(17)$ & $5227(10)$ & $8311(8)$ & 2940(5) & $16(2)$ \\
\hline $\mathrm{C}(18)$ & $6534(12)$ & $8127(8)$ & $2787(6)$ & $20(2)$ \\
\hline$C(19)$ & $7149(11)$ & $7528(9)$ & $3028(6)$ & $20(2)$ \\
\hline $\mathrm{C}(20)$ & $6466(10)$ & 7078(8) & $3418(5)$ & $16(2)$ \\
\hline $\mathrm{C}(21)$ & $7047(12)$ & 6421(7) & $3634(6)$ & $21(2)$ \\
\hline $\mathrm{C}(22)$ & $6392(13)$ & $5984(6)$ & 4013(5) & $20(2)$ \\
\hline$C(23)$ & $5108(14)$ & 6194(8) & $4188(5)$ & $21(2)$ \\
\hline$C(24)$ & $4489(15)$ & $6824(10)$ & $3975(8)$ & $19(2)$ \\
\hline$C(25)$ & $5130(12)$ & $7270(9)$ & $3576(7)$ & $16(2)$ \\
\hline$C(16 A)$ & $4509(10)$ & $7829(7)$ & $3365(5)$ & $14(3)$ \\
\hline$C(17 A)$ & $5326(12)$ & $8187(10)$ & 2985(7) & $17(3)$ \\
\hline$C(18 A)$ & $6665(13)$ & 7986(10) & 2894(8) & $17(3)$ \\
\hline$C(19 A)$ & $7152(14)$ & $7363(10)$ & $3157(8)$ & $20(3)$ \\
\hline$C(20 A)$ & $6350(14)$ & 6937(9) & $3521(8)$ & $19(2)$ \\
\hline$C(21 A)$ & $6831(16)$ & $6273(10)$ & 3772(8) & $24(3)$ \\
\hline$C(22 A)$ & $6070(20)$ & $5886(10)$ & 4142(9) & $33(3)$ \\
\hline$C(23 \mathrm{~A})$ & $4790(20)$ & $6136(10)$ & 4273(9) & $27(3)$ \\
\hline$C(24 \mathrm{~A})$ & $4280(20)$ & $6774(12)$ & $4027(10)$ & $18(2)$ \\
\hline$C(25 \mathrm{~A})$ & $5009(15)$ & $7189(10)$ & $3640(9)$ & $13(2)$ \\
\hline$C(26)$ & 2150(3) & $8110(2)$ & 2970(1) & $13(1)$ \\
\hline $\mathrm{C}(27)$ & $1426(3)$ & $7370(2)$ & $2928(1)$ & $15(1)$ \\
\hline $\mathrm{C}(28)$ & $471(3)$ & $7268(2)$ & 2464(1) & $12(1)$ \\
\hline$C(29)$ & $-68(3)$ & $6556(2)$ & 2377(1) & $14(1)$ \\
\hline $\mathrm{C}(30)$ & $-985(3)$ & 6431(2) & 1961(1) & $16(1)$ \\
\hline $\mathrm{C}(31)$ & $-1367(3)$ & $7033(2)$ & $1642(1)$ & $15(1)$ \\
\hline
\end{tabular}




\begin{tabular}{lllll}
\hline & $\mathbf{x}$ & $\mathbf{y}$ & $\mathbf{z}$ & $\mathbf{U}(\mathbf{e q})$ \\
\hline $\mathrm{C}(32)$ & $-872(3)$ & $7750(2)$ & $1727(1)$ & $17(1)$ \\
$\mathrm{C}(33)$ & $73(3)$ & $7864(2)$ & $2136(1)$ & $15(1)$ \\
$\mathrm{C}(34)$ & $1469(3)$ & $9272(2)$ & $4026(1)$ & $13(1)$ \\
$\mathrm{C}(35)$ & $432(3)$ & $8751(2)$ & $4004(1)$ & $16(1)$ \\
$\mathrm{C}(36)$ & $-851(3)$ & $8938(2)$ & $4183(1)$ & $18(1)$ \\
$\mathrm{C}(37)$ & $-1095(3)$ & $9633(2)$ & $4402(1)$ & $20(1)$ \\
$\mathrm{C}(38)$ & $-67(3)$ & $10154(2)$ & $4434(1)$ & $20(1)$ \\
$\mathrm{C}(39)$ & $1210(3)$ & $9977(2)$ & $4235(1)$ & $15(1)$ \\
$\mathrm{C}(40)$ & $4044(3)$ & $8735(2)$ & $4422(1)$ & $12(1)$ \\
$\mathrm{C}(41)$ & $3323(3)$ & $8420(2)$ & $4848(1)$ & $15(1)$ \\
$\mathrm{C}(42)$ & $3974(3)$ & $8108(2)$ & $5287(1)$ & $20(1)$ \\
$\mathrm{C}(43)$ & $5380(3)$ & $8107(2)$ & $5305(1)$ & $20(1)$ \\
$\mathrm{C}(44)$ & $6108(3)$ & $8420(2)$ & $4886(1)$ & $19(1)$ \\
$\mathrm{C}(45)$ & $5454(3)$ & $8732(2)$ & $4443(1)$ & $14(1)$ \\
$\mathrm{C}(46)$ & $8718(5)$ & $10225(3)$ & $1114(2)$ & $43(1)$ \\
$\mathrm{C}(51)$ & $6842(5)$ & $3771(3)$ & $3749(2)$ & $44(1)$ \\
$\mathrm{Cl}(1)$ & $2714(1)$ & $9781(1)$ & $2550(1)$ & $17(1)$ \\
$\mathrm{Cl}(2)$ & $-2496(1)$ & $6881(1)$ & $1112(1)$ & $20(1)$ \\
$\mathrm{Cl}(3)$ & $6866(2)$ & $3947(1)$ & $4444(1)$ & $64(1)$ \\
$\mathrm{Cl}(4)$ & $5427(2)$ & $3260(1)$ & $3547(1)$ & $73(1)$ \\
$\mathrm{Cl}(5)$ & $10049(1)$ & $9928(1)$ & $1542(1)$ & $48(1)$ \\
$\mathrm{Cl}(6)$ & $7348(1)$ & $9589(1)$ & $1144(1)$ & $47(1)$ \\
$\mathrm{N}(1)$ & $5450(2)$ & $10723(2)$ & $2858(1)$ & $12(1)$ \\
$\mathrm{O}(1)$ & $1573(3)$ & $6877(2)$ & $3263(1)$ & $28(1)$ \\
$\mathrm{P}(1)$ & $3201(1)$ & $9072(1)$ & $3806(1)$ & $11(1)$ \\
\hline & & & &
\end{tabular}


Table A5-1 Crystal data and structure refinement for cis-rac-41

\begin{tabular}{|c|c|c|}
\hline Chemical formula & \multicolumn{2}{|l|}{$\mathrm{C}_{50.50} \mathrm{H}_{41} \mathrm{Cl}_{3} \mathrm{O}_{2} \mathrm{P}_{2} \mathrm{Pd}$} \\
\hline Formula weight & \multicolumn{2}{|l|}{954.52} \\
\hline Temperature & \multicolumn{2}{|l|}{$103(2) \mathrm{K}$} \\
\hline Wavelength & \multicolumn{2}{|l|}{$0.71073 \AA$} \\
\hline Crystal size & \multicolumn{2}{|c|}{$0.260 \times 0.400 \times 0.420 \mathrm{~mm}$} \\
\hline Crystal habit & \multicolumn{2}{|l|}{ colorless block } \\
\hline Crystal system & \multicolumn{2}{|l|}{ triclinic } \\
\hline Space group & \multicolumn{2}{|l|}{$\mathrm{P}-1$} \\
\hline \multirow[t]{3}{*}{ Unit cell dimensions } & $a=13.2656(11) \AA$ & $\alpha=99.718(2)^{\circ}$ \\
\hline & $\mathrm{b}=13.8080(13) \AA$ & $\beta=116.4120(10)^{\circ}$ \\
\hline & $\mathrm{c}=14.7389(13) \AA$ & $\gamma=106.6050(10)^{\circ}$ \\
\hline Volume & \multicolumn{2}{|l|}{$2175.0(3) \AA^{3}$} \\
\hline $\mathbf{Z}$ & \multicolumn{2}{|l|}{2} \\
\hline Density (calculated) & \multicolumn{2}{|l|}{$1.457 \mathrm{~g} / \mathrm{cm}^{3}$} \\
\hline Absorption coefficient & \multicolumn{2}{|l|}{$0.725 \mathrm{~mm}^{-1}$} \\
\hline $\mathbf{F}(000)$ & \multicolumn{2}{|l|}{974} \\
\hline Theta range for data collection & \multicolumn{2}{|l|}{7.31 to $45.46^{\circ}$} \\
\hline Index ranges & \multicolumn{2}{|c|}{$-26<=\mathrm{h}<=26,-27<=\mathrm{k}<=27,-29<=1<=29$} \\
\hline Reflections collected & \multicolumn{2}{|l|}{123380} \\
\hline Independent reflections & \multicolumn{2}{|c|}{$36304[\mathrm{R}($ int $)=0.0796]$} \\
\hline Coverage of independent reflections & \multicolumn{2}{|l|}{$98.8 \%$} \\
\hline Absorption correction & \multicolumn{2}{|l|}{ multi-scan } \\
\hline Max. and min. transmission & \multicolumn{2}{|l|}{0.8339 and 0.7505} \\
\hline Structure solution technique & \multicolumn{2}{|l|}{ direct methods } \\
\hline Structure solution program & \multicolumn{2}{|c|}{ SHELXS-97 (Sheldrick, 2008) } \\
\hline Refinement method & \multicolumn{2}{|c|}{ Full-matrix least-squares on $\mathrm{F}^{2}$} \\
\hline Refinement program & \multicolumn{2}{|c|}{ SHELXL-97 (Sheldrick, 2008) } \\
\hline Function minimized & \multicolumn{2}{|l|}{$\Sigma \mathrm{w}\left(\mathrm{F}_{\mathrm{o}}^{2}-\mathrm{F}_{\mathrm{c}}^{2}\right)^{2}$} \\
\hline Data / restraints / parameters & \multicolumn{2}{|l|}{$36304 / 205 / 573$} \\
\hline Goodness-of-fit on $F^{2}$ & \multicolumn{2}{|l|}{1.002} \\
\hline$\Delta / \sigma_{\max }$ & \multicolumn{2}{|l|}{0.003} \\
\hline \multirow[t]{2}{*}{ Final $\mathbf{R}$ indices } & 24361 data; $\mathrm{I}>2 \sigma(\mathrm{I})$ & $\mathrm{R} 1=0.0484, \mathrm{wR} 2=0.0937$ \\
\hline & all data & $\mathrm{R} 1=0.0897, \mathrm{wR} 2=0.1112$ \\
\hline Weighting scheme & $\begin{array}{l}\mathrm{w}=1 /\left[\sigma^{2}\left(\mathrm{~F}_{\mathrm{o}}^{2}\right)+(0.039\right. \\
\text { where } \mathrm{P}=\left(\mathrm{F}_{\mathrm{o}}^{2}+2 \mathrm{~F}_{\mathrm{c}}^{2}\right) /\end{array}$ & $\left.\mathrm{P})^{2}+0.3957 \mathrm{P}\right]$ \\
\hline Largest diff. peak and hole & 1.296 and $-1.413 \mathrm{e}^{-}$ & \\
\hline R.M.S. deviation from mean & $0.139 \mathrm{e}^{-3}$ & \\
\hline
\end{tabular}


Table A5-2 Atomic coordinates and equivalent isotropic displacement parameters $\left(\AA^{2}\right)$ for cis-rac-41. $\mathrm{U}(\mathrm{eq})$ is defined as one third of the trace of the orthogonalized $U_{i j}$ tensor.

\begin{tabular}{|c|c|c|c|c|}
\hline & $\mathbf{x} / \mathbf{a}$ & $\mathbf{y} / \mathbf{b}$ & $\mathbf{z} / \mathbf{c}$ & $\mathrm{U}(\mathbf{e q})$ \\
\hline $\mathrm{Pd} 1$ & $0.973166(8)$ & $0.552962(7)$ & $0.735587(7)$ & $0.01032(2)$ \\
\hline $\mathrm{C} 1$ & $0.06084(11)$ & $0.44961(10)$ & $0.74985(9)$ & $0.01179(17)$ \\
\hline $\mathrm{C} 2$ & $0.99010(11)$ & $0.33733(10)$ & $0.71907(10)$ & $0.01394(19)$ \\
\hline $\mathrm{C} 3$ & $0.04325(12)$ & $0.26536(10)$ & $0.73050(11)$ & $0.0154(2)$ \\
\hline $\mathrm{C} 4$ & $0.17201(11)$ & $0.29941(10)$ & $0.77581(10)$ & $0.01331(19)$ \\
\hline $\mathrm{C} 5$ & $0.22889(13)$ & $0.22598(11)$ & $0.79178(12)$ & $0.0178(2)$ \\
\hline C6 & $0.35417(13)$ & $0.26130(11)$ & $0.83894(12)$ & $0.0179(2)$ \\
\hline $\mathrm{C} 7$ & $0.42786(12)$ & $0.37113(11)$ & $0.87132(10)$ & $0.0148(2)$ \\
\hline $\mathrm{C} 8$ & $0.37527(11)$ & $0.44391(10)$ & $0.85665(10)$ & $0.01240(18)$ \\
\hline $\mathrm{C} 9$ & $0.24559(11)$ & $0.41072(10)$ & $0.80830(9)$ & $0.01134(17)$ \\
\hline $\mathrm{C} 10$ & $0.18720(10)$ & $0.48436(9)$ & $0.79351(9)$ & $0.01017(16)$ \\
\hline $\mathrm{C} 11$ & $0.26612(10)$ & $0.60233(9)$ & $0.83090(9)$ & $0.01052(17)$ \\
\hline $\mathrm{C} 12$ & $0.32005(11)$ & $0.63456(10)$ & $0.76166(10)$ & $0.01212(18)$ \\
\hline $\mathrm{C} 13$ & $0.43134(11)$ & $0.74214(10)$ & $0.82314(10)$ & $0.01280(18)$ \\
\hline $\mathrm{C} 14$ & $0.47870(11)$ & $0.79911(10)$ & $0.76376(10)$ & $0.01380(19)$ \\
\hline $\mathrm{C} 15$ & $0.42980(13)$ & $0.75553(12)$ & $0.65325(11)$ & $0.0195(2)$ \\
\hline $\mathrm{C} 16$ & $0.47856(15)$ & $0.81213(14)$ & $0.60242(13)$ & $0.0245(3)$ \\
\hline $\mathrm{C} 17$ & $0.57672(15)$ & $0.91167(14)$ & $0.66285(14)$ & $0.0243(3)$ \\
\hline C18 & $0.62766(15)$ & $0.95661(13)$ & $0.77314(13)$ & $0.0239(3)$ \\
\hline C19 & $0.57828(13)$ & $0.90002(11)$ & $0.82284(12)$ & $0.0194(2)$ \\
\hline $\mathrm{C} 20$ & $0.21863(11)$ & $0.70711(10)$ & $0.98368(10)$ & $0.01232(18)$ \\
\hline $\mathrm{C} 21$ & $0.34354(12)$ & $0.76097(11)$ & $0.06503(10)$ & $0.0161(2)$ \\
\hline $\mathrm{C} 22$ & $0.37895(14)$ & $0.77893(13)$ & $0.17260(11)$ & $0.0219(3)$ \\
\hline $\mathrm{C} 23$ & $0.29080(16)$ & $0.74383(14)$ & $0.20029(12)$ & $0.0235(3)$ \\
\hline $\mathrm{C} 24$ & $0.16710(15)$ & $0.69087(13)$ & $0.12057(12)$ & $0.0218(3)$ \\
\hline $\mathrm{C} 25$ & $0.13108(13)$ & $0.67193(12)$ & $0.01248(11)$ & $0.0164(2)$ \\
\hline $\mathrm{C} 26$ & $0.21075(11)$ & $0.79175(10)$ & $0.81017(10)$ & $0.01195(18)$ \\
\hline $\mathrm{C} 27$ & $0.28838(13)$ & $0.89338(11)$ & $0.88931(11)$ & $0.0165(2)$ \\
\hline $\mathrm{C} 28$ & $0.32457(16)$ & $0.98358(12)$ & $0.86264(13)$ & $0.0241(3)$ \\
\hline $\mathrm{C} 29$ & $0.28217(17)$ & $0.97196(12)$ & $0.75508(14)$ & $0.0251(3)$ \\
\hline $\mathrm{C} 30$ & $0.20371(15)$ & $0.87248(12)$ & $0.67422(12)$ & $0.0197(2)$ \\
\hline $\mathrm{C} 31$ & $0.16732(11)$ & $0.78252(10)$ & $0.70126(10)$ & $0.01366(19)$ \\
\hline $\mathrm{C} 32$ & $0.05863(14)$ & $0.66531(14)$ & $0.51710(11)$ & $0.0218(3)$ \\
\hline C33 & $0.79132(11)$ & $0.64181(10)$ & $0.80846(10)$ & $0.01267(18)$ \\
\hline C34 & $0.74833(12)$ & $0.71444(11)$ & $0.84037(11)$ & $0.0152(2)$ \\
\hline $\mathrm{C} 35$ & $0.70083(12)$ & $0.69926(12)$ & $0.90637(11)$ & $0.0167(2)$ \\
\hline $\mathrm{C} 36$ & $0.69609(12)$ & $0.61170(12)$ & $0.94148(11)$ & $0.0176(2)$ \\
\hline $\mathrm{C} 37$ & $0.73758(13)$ & $0.53867(12)$ & $0.90962(12)$ & $0.0190(2)$ \\
\hline C38 & $0.78456(12)$ & $0.55347(11)$ & $0.84297(11)$ & $0.0156(2)$ \\
\hline
\end{tabular}




\begin{tabular}{lllll}
\hline & $\mathbf{x} / \mathbf{a}$ & $\mathbf{y} / \mathbf{b}$ & $\mathbf{z} / \mathbf{c}$ & $\mathbf{U}(\mathbf{e q})$ \\
\hline $\mathrm{C} 39$ & $0.74706(11)$ & $0.64226(10)$ & $0.59520(10)$ & $0.01352(19)$ \\
$\mathrm{C} 40$ & $0.62796(12)$ & $0.63090(13)$ & $0.56488(12)$ & $0.0193(2)$ \\
$\mathrm{C} 41$ & $0.54421(14)$ & $0.61709(15)$ & $0.45903(13)$ & $0.0252(3)$ \\
$\mathrm{C} 42$ & $0.58003(15)$ & $0.61674(15)$ & $0.38400(12)$ & $0.0251(3)$ \\
$\mathrm{C} 43$ & $0.69855(16)$ & $0.62819(16)$ & $0.41371(12)$ & $0.0272(3)$ \\
$\mathrm{C} 44$ & $0.78127(13)$ & $0.63904(14)$ & $0.51850(11)$ & $0.0222(3)$ \\
$\mathrm{C} 45$ & $0.9398(4)$ & $0.8161(3)$ & $0.7847(4)$ & $0.0143(8)$ \\
$\mathrm{C} 46$ & $0.8959(6)$ & $0.8770(3)$ & $0.7234(3)$ & $0.0215(7)$ \\
$\mathrm{C} 47$ & $0.9464(7)$ & $0.9885(3)$ & $0.7698(4)$ & $0.0274(9)$ \\
$\mathrm{C} 48$ & $0.0408(5)$ & $0.0390(3)$ & $0.8775(4)$ & $0.0249(8)$ \\
$\mathrm{C} 49$ & $0.0847(4)$ & $0.9780(4)$ & $0.9388(4)$ & $0.0213(8)$ \\
$\mathrm{C} 50$ & $0.0342(5)$ & $0.8666(4)$ & $0.8924(5)$ & $0.0158(7)$ \\
$\mathrm{C} 45 \mathrm{~A}$ & $0.9455(6)$ & $0.8127(4)$ & $0.7911(6)$ & $0.0132(10)$ \\
$\mathrm{C} 46 \mathrm{~A}$ & $0.9250(11)$ & $0.8749(5)$ & $0.7252(4)$ & $0.0251(15)$ \\
$\mathrm{C} 47 \mathrm{~A}$ & $0.9808(13)$ & $0.9865(5)$ & $0.7707(6)$ & $0.0349(19)$ \\
$\mathrm{C} 48 \mathrm{~A}$ & $0.0573(9)$ & $0.0360(5)$ & $0.8820(6)$ & $0.0314(16)$ \\
C49A & $0.0778(7)$ & $0.9739(7)$ & $0.9479(4)$ & $0.0198(11)$ \\
C50A & $0.0219(8)$ & $0.8622(6)$ & $0.9024(6)$ & $0.0140(9)$ \\
C51 & $0.9267(5)$ & $0.9101(4)$ & $0.4934(4)$ & $0.0399(9)$ \\
C13 & $0.79936(12)$ & $0.93821(11)$ & $0.47810(9)$ & $0.0460(3)$ \\
C14 & $0.03742(14)$ & $0.01560(13)$ & $0.49351(12)$ & $0.0564(3)$ \\
C11 & $0.77339(3)$ & $0.41399(3)$ & $0.61464(3)$ & $0.01776(6)$ \\
C12 & $0.63812(5)$ & $0.98239(5)$ & $0.59987(4)$ & $0.04185(12)$ \\
O1 & $0.48434(9)$ & $0.78026(9)$ & $0.92141(8)$ & $0.01841(18)$ \\
O2 & $0.09044(9)$ & $0.68147(8)$ & $0.62684(8)$ & $0.01671(17)$ \\
P1 & $0.16705(3)$ & $0.67021(3)$ & $0.84092(2)$ & $0.00961(5)$ \\
P2 & $0.86611(3)$ & $0.66639(3)$ & $0.73153(3)$ & $0.01135(5)$ \\
\hline & & & & \\
\end{tabular}


Table A6-1 Crystal data and structure refinement for $(Z)-\left(S_{\mathrm{C}}, S_{\mathrm{P}}, S_{\mathrm{N}}\right)-43$

\begin{tabular}{|c|c|c|}
\hline Chemical formula & \multicolumn{2}{|l|}{$\mathrm{C}_{39} \mathrm{H}_{37} \mathrm{Cl}_{5} \mathrm{NO}_{4} \mathrm{PPd}$} \\
\hline Formula weight & \multicolumn{2}{|l|}{898.32} \\
\hline Temperature & \multicolumn{2}{|l|}{$103(2) \mathrm{K}$} \\
\hline Wavelength & \multicolumn{2}{|l|}{$0.71073 \AA$} \\
\hline Crystal size & \multicolumn{2}{|c|}{$0.340 \times 0.340 \times 0.360 \mathrm{~mm}$} \\
\hline Crystal habit & \multicolumn{2}{|l|}{ colorless block } \\
\hline Crystal system & \multicolumn{2}{|l|}{ monoclinic } \\
\hline Space group & \multicolumn{2}{|l|}{ P 1211} \\
\hline \multirow[t]{3}{*}{ Unit cell dimensions } & $\mathrm{a}=13.5433(9) \AA$ & $\alpha=90^{\circ}$ \\
\hline & $\mathrm{b}=8.3171(6) \AA$ & $\beta=97.313(3)^{\circ}$ \\
\hline & $c=16.8968(15) \AA$ & $\gamma=90^{\circ}$ \\
\hline Volume & \multicolumn{2}{|l|}{$1887.8(2) \AA^{3}$} \\
\hline $\mathbf{Z}$ & \multicolumn{2}{|l|}{2} \\
\hline Density (calculated) & \multicolumn{2}{|l|}{$1.580 \mathrm{~g} / \mathrm{cm}^{3}$} \\
\hline Absorption coefficient & \multicolumn{2}{|l|}{$0.930 \mathrm{~mm}^{-1}$} \\
\hline $\mathbf{F}(000)$ & \multicolumn{2}{|l|}{912} \\
\hline Theta range for data collection & \multicolumn{2}{|l|}{1.21 to $31.33^{\circ}$} \\
\hline Index ranges & \multicolumn{2}{|c|}{$-19<=\mathrm{h}<=19,-12<=\mathrm{k}<=12,-24<=1<=24$} \\
\hline Reflections collected & \multicolumn{2}{|l|}{40922} \\
\hline Independent reflections & \multicolumn{2}{|c|}{$12169[\mathrm{R}(\mathrm{int})=0.0417]$} \\
\hline Coverage of independent reflections & \multicolumn{2}{|l|}{$98.7 \%$} \\
\hline Absorption correction & \multicolumn{2}{|l|}{ multi-scan } \\
\hline Max. and min. transmission & \multicolumn{2}{|l|}{0.7427 and 0.7306} \\
\hline Structure solution technique & \multicolumn{2}{|l|}{ direct methods } \\
\hline Structure solution program & \multicolumn{2}{|c|}{ SHELXS-97 (Sheldrick, 2008) } \\
\hline Refinement method & \multicolumn{2}{|c|}{ Full-matrix least-squares on $\mathrm{F}^{2}$} \\
\hline Refinement program & \multicolumn{2}{|c|}{ SHELXL-97 (Sheldrick, 2008) } \\
\hline Function minimized & \multicolumn{2}{|l|}{$\Sigma \mathrm{w}\left(\mathrm{F}_{\mathrm{o}}^{2}-\mathrm{F}_{\mathrm{c}}^{2}\right)^{2}$} \\
\hline Data / restraints / parameters & \multicolumn{2}{|l|}{$12169 / 1 / 465$} \\
\hline Goodness-of-fit on $F^{2}$ & \multicolumn{2}{|l|}{1.082} \\
\hline$\Delta / \sigma_{\max }$ & \multicolumn{2}{|l|}{0.004} \\
\hline Final $R$ indices & 11139 data; $\mathrm{I}>2 \sigma(\mathrm{I})$ & $\mathrm{R} 1=0.0295, \mathrm{wR} 2=0.0704$ \\
\hline & all data & $\mathrm{R} 1=0.0363, \mathrm{wR} 2=0.0883$ \\
\hline Weighting scheme & $\begin{array}{l}\mathrm{w}=1 /\left[\sigma^{2}\left(\mathrm{~F}_{\mathrm{o}}^{2}\right)+(0.048\right. \\
\text { where } \mathrm{P}=\left(\mathrm{F}_{\mathrm{o}}^{2}+2 \mathrm{~F}_{\mathrm{c}}^{2}\right) / 3\end{array}$ & )$\left.^{2}+0.0000 \mathrm{P}\right]$ \\
\hline Absolute structure parameter & $-0.0(0)$ & \\
\hline Largest diff. peak and hole & 0.713 and $-0.571 \mathrm{e}^{-}$ & \\
\hline R.M.S. deviation from mean & $0.142 \mathrm{e}^{-3}$ & \\
\hline
\end{tabular}


Table A6-2 Atomic coordinates and equivalent isotropic displacement parameters $\left(\AA^{2}\right)$ for $(Z)-\left(S_{C}, S_{P}, S_{N}\right)-43$. $U(e q)$ is defined as one third of the trace of the orthogonalized $U_{i j}$ tensor.

\begin{tabular}{|c|c|c|c|c|}
\hline & $\mathbf{x} / \mathbf{a}$ & $y / b$ & $\mathrm{z} / \mathrm{c}$ & $\mathrm{U}(\mathbf{e q})$ \\
\hline Pd1 & $0.624046(12)$ & $0.59533(2)$ & $0.660888(9)$ & $0.01101(4)$ \\
\hline $\mathrm{C} 1$ & $0.70904(18)$ & $0.7926(3)$ & $0.65521(15)$ & $0.0128(5)$ \\
\hline $\mathrm{C} 2$ & $0.72886(19)$ & $0.8520(3)$ & $0.58001(15)$ & $0.0155(5)$ \\
\hline $\mathrm{C} 3$ & $0.7904(2)$ & $0.9800(3)$ & $0.57367(15)$ & $0.0163(5)$ \\
\hline $\mathrm{C} 4$ & $0.83587(19)$ & $0.0618(3)$ & $0.64189(15)$ & $0.0137(5)$ \\
\hline $\mathrm{C} 5$ & $0.90315(19)$ & $0.1901(3)$ & $0.63635(16)$ & $0.0161(5)$ \\
\hline C6 & $0.9481(2)$ & $0.2663(3)$ & $0.70347(17)$ & $0.0175(5)$ \\
\hline $\mathrm{C} 7$ & $0.9273(2)$ & $0.2157(3)$ & $0.77887(17)$ & $0.0185(5)$ \\
\hline $\mathrm{C} 8$ & $0.86254(17)$ & $0.0925(4)$ & $0.78665(14)$ & $0.0168(4)$ \\
\hline C9 & $0.81533(19)$ & $0.0097(3)$ & $0.71836(15)$ & $0.0136(5)$ \\
\hline $\mathrm{C} 10$ & $0.75111(18)$ & $0.8735(3)$ & $0.72301(15)$ & $0.0124(4)$ \\
\hline $\mathrm{C} 11$ & $0.73336(18)$ & $0.8104(3)$ & $0.80438(15)$ & $0.0135(5)$ \\
\hline $\mathrm{C} 12$ & $0.82270(19)$ & $0.7058(3)$ & $0.84046(15)$ & $0.0160(5)$ \\
\hline $\mathrm{C} 13$ & $0.84392(19)$ & $0.7141(4)$ & $0.93096(16)$ & $0.0177(5)$ \\
\hline $\mathrm{C} 14$ & $0.86311(19)$ & $0.5649(3)$ & $0.97964(15)$ & $0.0172(6)$ \\
\hline $\mathrm{C} 15$ & $0.8883(2)$ & $0.5819(4)$ & $0.06212(15)$ & $0.0219(5)$ \\
\hline $\mathrm{C} 16$ & $0.9049(2)$ & $0.4477(4)$ & $0.11071(17)$ & $0.0230(6)$ \\
\hline $\mathrm{C} 17$ & $0.8959(2)$ & $0.2974(4)$ & $0.07651(17)$ & $0.0194(5)$ \\
\hline $\mathrm{C} 18$ & $0.8719(2)$ & $0.2756(4)$ & $0.99515(17)$ & $0.0221(6)$ \\
\hline C19 & $0.8551(2)$ & $0.4100(4)$ & $0.94712(17)$ & $0.0191(6)$ \\
\hline $\mathrm{C} 20$ & $0.72261(19)$ & $0.4432(3)$ & $0.52603(17)$ & $0.0171(5)$ \\
\hline $\mathrm{C} 21$ & $0.6928(2)$ & $0.3357(3)$ & $0.45426(17)$ & $0.0192(5)$ \\
\hline $\mathrm{C} 22$ & $0.5992(2)$ & $0.2554(3)$ & $0.47711(17)$ & $0.0188(5)$ \\
\hline $\mathrm{C} 23$ & $0.54930(18)$ & $0.3894(3)$ & $0.52156(15)$ & $0.0123(4)$ \\
\hline $\mathrm{C} 24$ & $0.50392(18)$ & $0.3290(3)$ & $0.59374(15)$ & $0.0129(5)$ \\
\hline $\mathrm{C} 25$ & $0.61513(18)$ & $0.5494(3)$ & $0.86477(15)$ & $0.0140(5)$ \\
\hline $\mathrm{C} 26$ & $0.61667(17)$ & $0.6053(4)$ & $0.94394(14)$ & $0.0161(4)$ \\
\hline $\mathrm{C} 27$ & $0.6450(2)$ & $0.8287(4)$ & $0.03372(17)$ & $0.0256(6)$ \\
\hline $\mathrm{C} 28$ & $0.6148(2)$ & $0.4962(4)$ & $0.00628(16)$ & $0.0205(6)$ \\
\hline $\mathrm{C} 29$ & $0.6126(2)$ & $0.3329(4)$ & $0.99012(17)$ & $0.0220(6)$ \\
\hline $\mathrm{C} 30$ & $0.6111(2)$ & $0.2752(4)$ & $0.91299(17)$ & $0.0212(5)$ \\
\hline $\mathrm{C} 31$ & $0.6122(2)$ & $0.3841(3)$ & $0.85061(16)$ & $0.0177(5)$ \\
\hline $\mathrm{C} 32$ & $0.51121(19)$ & $0.8157(3)$ & $0.78373(15)$ & $0.0140(5)$ \\
\hline C33 & $0.5132(2)$ & $0.9803(3)$ & $0.76686(16)$ & $0.0190(5)$ \\
\hline $\mathrm{C} 34$ & $0.4258(2)$ & $0.0701(3)$ & $0.76290(16)$ & $0.0211(6)$ \\
\hline $\mathrm{C} 35$ & $0.3371(2)$ & $0.9969(4)$ & $0.77469(17)$ & $0.0210(6)$ \\
\hline $\mathrm{C} 36$ & $0.3347(2)$ & $0.8330(4)$ & $0.78970(17)$ & $0.0211(6)$ \\
\hline $\mathrm{C} 37$ & $0.42104(19)$ & $0.7435(3)$ & $0.79466(16)$ & $0.0180(5)$ \\
\hline C38 & $0.2595(3)$ & $0.3865(4)$ & $0.6599(2)$ & $0.0294(7)$ \\
\hline
\end{tabular}




\begin{tabular}{lllll}
\hline & $\mathbf{x} / \mathbf{a}$ & $\mathbf{y} / \mathbf{b}$ & $\mathbf{z} / \mathbf{c}$ & $\mathbf{U}(\mathbf{e q})$ \\
\hline $\mathrm{C} 39$ & $0.9912(2)$ & $0.7098(4)$ & $0.6437(2)$ & $0.0294(7)$ \\
$\mathrm{C} 11$ & $0.91413(5)$ & $0.12722(8)$ & $0.13674(4)$ & $0.02599(16)$ \\
$\mathrm{C} 12$ & $0.23769(7)$ & $0.41210(11)$ & $0.75982(5)$ & $0.03652(19)$ \\
$\mathrm{Cl} 3$ & $0.17939(6)$ & $0.24040(10)$ & $0.61094(5)$ & $0.03109(17)$ \\
$\mathrm{C} 14$ & $0.00299(6)$ & $0.58539(13)$ & $0.56109(5)$ & $0.03563(17)$ \\
$\mathrm{C} 15$ & $0.08220(7)$ & $0.86156(11)$ & $0.65530(6)$ & $0.0388(2)$ \\
$\mathrm{N} 1$ & $0.62725(16)$ & $0.5150(3)$ & $0.54278(13)$ & $0.0110(4)$ \\
O1 & $0.53152(14)$ & $0.3942(2)$ & $0.66158(11)$ & $0.0165(4)$ \\
O2 & $0.43967(14)$ & $0.2224(2)$ & $0.58357(11)$ & $0.0181(4)$ \\
O3 & $0.84717(16)$ & $0.8452(3)$ & $0.96307(12)$ & $0.0216(4)$ \\
O4 & $0.62196(15)$ & $0.7672(2)$ & $0.95359(11)$ & $0.0210(4)$ \\
P1 & $0.61979(5)$ & $0.68842(8)$ & $0.78296(4)$ & $0.01220(12)$ \\
\hline
\end{tabular}


Table A7-1 Crystal data and structure refinement for $(R, S)-46$

\begin{tabular}{|c|c|c|}
\hline Chemical formula & \multicolumn{2}{|l|}{$\mathrm{C}_{44} \mathrm{H}_{40} \mathrm{ClN}_{2} \mathrm{O}_{5} \mathrm{PPd}$} \\
\hline Formula weight & \multicolumn{2}{|l|}{849.60} \\
\hline Temperature & \multicolumn{2}{|l|}{$153(2) \mathrm{K}$} \\
\hline Wavelength & \multicolumn{2}{|l|}{$0.71073 \AA$} \\
\hline Crystal size & \multicolumn{2}{|c|}{$0.120 \times 0.300 \times 0.400 \mathrm{~mm}$} \\
\hline Crystal habit & \multicolumn{2}{|l|}{ colorless block } \\
\hline Crystal system & \multicolumn{2}{|l|}{ monoclinic } \\
\hline Space group & \multicolumn{2}{|l|}{ P 1211} \\
\hline \multirow[t]{3}{*}{ Unit cell dimensions } & $a=10.5693(17) \AA$ & $\alpha=90^{\circ}$ \\
\hline & $\mathrm{b}=14.901(2) \AA$ & $\beta=109.764(4)^{\circ}$ \\
\hline & $\mathrm{c}=12.849(2) \AA$ & $\gamma=90^{\circ}$ \\
\hline Volume & \multicolumn{2}{|l|}{$1904.4(5) \AA^{3}$} \\
\hline $\mathbf{Z}$ & \multicolumn{2}{|l|}{2} \\
\hline Density (calculated) & \multicolumn{2}{|l|}{$1.482 \mathrm{~g} / \mathrm{cm}^{3}$} \\
\hline Absorption coefficient & \multicolumn{2}{|l|}{$0.649 \mathrm{~mm}^{-1}$} \\
\hline $\mathbf{F}(000)$ & \multicolumn{2}{|l|}{872} \\
\hline Theta range for data collection & \multicolumn{2}{|l|}{1.68 to $27.61^{\circ}$} \\
\hline Index ranges & \multicolumn{2}{|c|}{$-12<=\mathrm{h}<=13,-19<=\mathrm{k}<=19,-16<=1<=16$} \\
\hline Reflections collected & \multicolumn{2}{|c|}{21590} \\
\hline Independent reflections & \multicolumn{2}{|c|}{$8813[\mathrm{R}(\mathrm{int})=0.0620]$} \\
\hline $\begin{array}{l}\text { Coverage of independent } \\
\text { reflections }\end{array}$ & \multicolumn{2}{|c|}{$99.8 \%$} \\
\hline Absorption correction & \multicolumn{2}{|l|}{ multi-scan } \\
\hline Max. and min. transmission & \multicolumn{2}{|l|}{0.9262 and 0.7813} \\
\hline Structure solution technique & \multicolumn{2}{|l|}{ direct methods } \\
\hline Structure solution program & \multicolumn{2}{|c|}{ SHELXS-97 (Sheldrick, 2008) } \\
\hline Refinement method & \multicolumn{2}{|c|}{ Full-matrix least-squares on $\mathrm{F}^{2}$} \\
\hline Refinement program & \multicolumn{2}{|c|}{ SHELXL-97 (Sheldrick, 2008) } \\
\hline Function minimized & \multicolumn{2}{|c|}{$\Sigma \mathrm{w}\left(\mathrm{F}_{\mathrm{o}}^{2}-\mathrm{F}_{\mathrm{c}}^{2}\right)^{2}$} \\
\hline Data / restraints / parameters & \multicolumn{2}{|l|}{8813 / 283 / 536} \\
\hline Goodness-of-fit on $F^{2}$ & \multicolumn{2}{|l|}{1.126} \\
\hline$\Delta / \sigma_{\max }$ & \multicolumn{2}{|l|}{0.001} \\
\hline Final $R$ indices & $\begin{array}{l}6883 \text { data; } \\
\mathrm{I}>2 \sigma(\mathrm{I})\end{array}$ & $\mathrm{R} 1=0.0773, w \mathrm{R} 2=0.1996$ \\
\hline & all data $\quad \mathrm{R}$ & $\mathrm{R} 1=0.1087, \mathrm{wR} 2=0.2333$ \\
\hline Weighting scheme & $\begin{array}{l}\mathrm{w}=1 /\left[\sigma^{2}\left(\mathrm{~F}_{\mathrm{o}}^{2}\right)+(0.110\right. \\
\text { where } \mathrm{P}=\left(\mathrm{F}_{\mathrm{o}}^{2}+2 \mathrm{~F}_{\mathrm{c}}^{2}\right) /\end{array}$ & $\left.107 \mathrm{P})^{2}+9.9362 \mathrm{P}\right]$ \\
\hline Absolute structure parameter & $-0.0(1)$ & \\
\hline Largest diff. peak and hole & 2.907 and $-2.216 \mathrm{e} \AA$ & \\
\hline R.M.S. deviation from mean & $0.255 \mathrm{e}^{-3}$ & \\
\hline
\end{tabular}


Table A7-2 Atomic coordinates and equivalent isotropic displacement parameters $\left(\AA^{2}\right)$ for $(R, S)-46$. $U(e q)$ is defined as one third of the trace of the orthogonalized $U_{i j}$ tensor.

\begin{tabular}{|c|c|c|c|c|}
\hline & $\mathbf{x} / \mathbf{a}$ & $y / b$ & $\mathrm{z} / \mathrm{c}$ & $\mathrm{U}(\mathbf{e q})$ \\
\hline $\mathrm{Pd} 1$ & $0.36306(7)$ & $0.62928(4)$ & $0.77418(5)$ & $0.02166(18)$ \\
\hline $\mathrm{C} 1$ & $0.1731(9)$ & $0.6785(6)$ & $0.7144(8)$ & $0.0229(19)$ \\
\hline $\mathrm{C} 2$ & $0.0552(10)$ & $0.6474(7)$ & $0.7330(9)$ & $0.030(2)$ \\
\hline $\mathrm{C} 3$ & $0.9403(11)$ & $0.6944(8)$ & $0.6974(9)$ & $0.035(3)$ \\
\hline $\mathrm{C} 4$ & $0.9318(10)$ & $0.7783(8)$ & $0.6428(8)$ & $0.029(2)$ \\
\hline $\mathrm{C} 5$ & $0.8140(12)$ & $0.8321(8)$ & $0.6108(10)$ & $0.035(2)$ \\
\hline C6 & $0.8123(11)$ & $0.9160(8)$ & $0.5643(9)$ & $0.036(2)$ \\
\hline $\mathrm{C} 7$ & $0.9269(12)$ & $0.9476(7)$ & $0.5453(9)$ & $0.033(2)$ \\
\hline $\mathrm{C} 8$ & $0.0408(10)$ & $0.8970(7)$ & $0.5733(9)$ & $0.029(2)$ \\
\hline C9 & $0.0501(10)$ & $0.8102(6)$ & $0.6241(7)$ & $0.0214(19)$ \\
\hline $\mathrm{C} 10$ & $0.1680(10)$ & $0.7567(6)$ & $0.6567(7)$ & $0.024(2)$ \\
\hline $\mathrm{C} 11$ & $0.2937(10)$ & $0.7894(6)$ & $0.6376(7)$ & $0.0204(19)$ \\
\hline $\mathrm{C} 12$ & $0.3725(12)$ & $0.8558(6)$ & $0.7257(9)$ & $0.033(2)$ \\
\hline $\mathrm{C} 13$ & $0.5062(11)$ & $0.7330(7)$ & $0.6252(9)$ & $0.030(2)$ \\
\hline $\mathrm{C} 14$ & $0.3056(13)$ & $0.6530(7)$ & $0.5316(7)$ & $0.037(3)$ \\
\hline $\mathrm{C} 15$ & $0.6753(11)$ & $0.6558(6)$ & $0.8773(8)$ & $0.027(2)$ \\
\hline $\mathrm{C} 16$ & $0.8063(10)$ & $0.6397(8)$ & $0.9389(8)$ & $0.030(2)$ \\
\hline $\mathrm{C} 17$ & $0.8415(10)$ & $0.5586(7)$ & $0.0013(8)$ & $0.028(2)$ \\
\hline C18 & $0.9712(11)$ & $0.5383(8)$ & $0.0687(8)$ & $0.031(2)$ \\
\hline C19 & $0.9986(12)$ & $0.4612(10)$ & $0.1285(10)$ & $0.043(3)$ \\
\hline $\mathrm{C} 20$ & $0.8941(12)$ & $0.3983(8)$ & $0.1157(9)$ & $0.033(2)$ \\
\hline $\mathrm{C} 21$ & $0.7668(12)$ & $0.4167(7)$ & $0.0509(9)$ & $0.034(2)$ \\
\hline $\mathrm{C} 22$ & $0.7360(10)$ & $0.4987(6)$ & $0.9903(7)$ & $0.023(2)$ \\
\hline $\mathrm{C} 23$ & $0.6028(10)$ & $0.5226(6)$ & $0.9290(7)$ & $0.0212(19)$ \\
\hline $\mathrm{C} 24$ & $0.4870(10)$ & $0.4624(5)$ & $0.9231(7)$ & $0.0184(18)$ \\
\hline $\mathrm{C} 25$ & $0.4698(10)$ & $0.3869(6)$ & $0.8341(8)$ & $0.0223(19)$ \\
\hline $\mathrm{C} 26$ & $0.4166(11)$ & $0.3008(6)$ & $0.8682(9)$ & $0.029(2)$ \\
\hline $\mathrm{C} 27$ & $0.3577(11)$ & $0.2345(6)$ & $0.7795(8)$ & $0.025(2)$ \\
\hline $\mathrm{C} 28$ & $0.3665(10)$ & $0.2392(6)$ & $0.6751(8)$ & $0.025(2)$ \\
\hline $\mathrm{C} 29$ & $0.3108(14)$ & $0.1743(6)$ & $0.5959(9)$ & $0.038(3)$ \\
\hline $\mathrm{C} 30$ & $0.2338(14)$ & $0.1064(6)$ & $0.6180(10)$ & $0.039(3)$ \\
\hline $\mathrm{C} 31$ & $0.2191(14)$ & $0.1024(7)$ & $0.7200(11)$ & $0.041(3)$ \\
\hline $\mathrm{C} 32$ & $0.2808(13)$ & $0.1640(7)$ & $0.8022(10)$ & $0.037(3)$ \\
\hline C33 & $0.1989(10)$ & $0.4502(6)$ & $0.8528(8)$ & $0.0212(19)$ \\
\hline C34 & $0.1440(11)$ & $0.4200(7)$ & $0.7409(8)$ & $0.034(2)$ \\
\hline $\mathrm{C} 35$ & $0.0462(14)$ & $0.3562(9)$ & $0.7087(10)$ & $0.047(3)$ \\
\hline $\mathrm{C} 36$ & $0.9956(12)$ & $0.3208(8)$ & $0.7856(10)$ & $0.042(3)$ \\
\hline $\mathrm{C} 37$ & $0.0405(13)$ & $0.3491(9)$ & $0.8926(11)$ & $0.043(3)$ \\
\hline C38 & $0.1426(10)$ & $0.4131(7)$ & $0.9274(9)$ & $0.027(2)$ \\
\hline
\end{tabular}




\begin{tabular}{lllll}
\hline & $\mathbf{x} / \mathbf{a}$ & $\mathbf{y} / \mathbf{b}$ & $\mathbf{z} / \mathbf{c}$ & $\mathbf{U}(\mathbf{e q})$ \\
\hline $\mathrm{C} 39$ & $0.3342(11)$ & $0.5778(6)$ & $0.0253(8)$ & $0.025(2)$ \\
$\mathrm{C} 40$ & $0.3844(11)$ & $0.5303(8)$ & $0.1257(8)$ & $0.030(2)$ \\
$\mathrm{C} 41$ & $0.3795(13)$ & $0.5711(8)$ & $0.2227(9)$ & $0.038(2)$ \\
$\mathrm{C} 42$ & $0.3318(12)$ & $0.6503(6)$ & $0.2197(8)$ & $0.032(2)$ \\
$\mathrm{C} 43$ & $0.2786(11)$ & $0.6996(7)$ & $0.1216(9)$ & $0.031(2)$ \\
$\mathrm{C} 44$ & $0.2818(11)$ & $0.6630(7)$ & $0.0267(10)$ & $0.029(2)$ \\
$\mathrm{N} 1$ & $0.3745(8)$ & $0.7085(5)$ & $0.6372(6)$ & $0.0175(15)$ \\
$\mathrm{N} 2$ & $0.5729(8)$ & $0.5977(5)$ & $0.8673(6)$ & $0.0207(16)$ \\
O1 & $0.4278(9)$ & $0.2860(5)$ & $0.9626(6)$ & $0.0393(19)$ \\
$\mathrm{C} 11$ & $0.6263(8)$ & $0.4468(5)$ & $0.5942(6)$ & $0.0361(14)$ \\
O2 & $0.6327(18)$ & $0.3544(9)$ & $0.6306(13)$ & $0.056(4)$ \\
O3 & $0.606(2)$ & $0.5067(11)$ & $0.6682(14)$ & $0.087(5)$ \\
O4 & $0.5240(14)$ & $0.4526(9)$ & $0.4833(11)$ & $0.065(4)$ \\
O5 & $0.7472(13)$ & $0.4689(10)$ & $0.5764(13)$ & $0.069(4)$ \\
C11A & $0.631(3)$ & $0.4506(18)$ & $0.613(2)$ & $0.038(5)$ \\
O2A & $0.667(5)$ & $0.361(2)$ & $0.656(4)$ & $0.044(8)$ \\
O3A & $0.511(4)$ & $0.480(3)$ & $0.620(3)$ & $0.046(7)$ \\
O4A & $0.644(5)$ & $0.457(3)$ & $0.504(3)$ & $0.059(7)$ \\
O5A & $0.729(4)$ & $0.514(3)$ & $0.672(4)$ & $0.064(8)$ \\
P1 & $0.3340(3)$ & $0.53048(15)$ & $0.89424(19)$ & $0.0196(5)$ \\
\hline & & & &
\end{tabular}


Table A8-1 Crystal data and structure refinement for rac-47

\begin{tabular}{|c|c|c|}
\hline Chemical formula & \multicolumn{2}{|c|}{$\mathrm{C}_{31} \mathrm{H}_{26.50} \mathrm{Cl}_{2} \mathrm{NO}_{1.25} \mathrm{PPd}$} \\
\hline Formula weight & \multicolumn{2}{|l|}{641.30} \\
\hline Temperature & \multicolumn{2}{|l|}{$103(2) \mathrm{K}$} \\
\hline Wavelength & \multicolumn{2}{|l|}{$0.71073 \AA$} \\
\hline Crystal size & \multicolumn{2}{|c|}{$0.020 \times 0.120 \times 0.200 \mathrm{~mm}$} \\
\hline Crystal habit & \multicolumn{2}{|l|}{ yellow plate } \\
\hline Crystal system & \multicolumn{2}{|l|}{ monoclinic } \\
\hline Space group & \multicolumn{2}{|l|}{ P $121 / n 1$} \\
\hline \multirow[t]{3}{*}{ Unit cell dimensions } & $a=10.7255(10) \AA$ & $\alpha=90^{\circ}$ \\
\hline & $\mathrm{b}=40.711(4) \AA$ & $\beta=110.519(3)^{\circ}$ \\
\hline & $c=13.3492(13) \AA$ & $\gamma=90^{\circ}$ \\
\hline Volume & \multicolumn{2}{|l|}{$5459.1(9) \AA^{3}$} \\
\hline $\mathbf{Z}$ & \multicolumn{2}{|l|}{8} \\
\hline Density (calculated) & \multicolumn{2}{|l|}{$1.561 \mathrm{~g} / \mathrm{cm}^{3}$} \\
\hline Absorption coefficient & \multicolumn{2}{|l|}{$0.961 \mathrm{~mm}^{-1}$} \\
\hline $\mathbf{F}(000)$ & \multicolumn{2}{|l|}{2596} \\
\hline Theta range for data collection & \multicolumn{2}{|l|}{1.70 to $30.48^{\circ}$} \\
\hline Index ranges & \multicolumn{2}{|c|}{$-13<=\mathrm{h}<=14,-50<=\mathrm{k}<=53,-17<=1<=18$} \\
\hline Reflections collected & \multicolumn{2}{|c|}{41271} \\
\hline Independent reflections & \multicolumn{2}{|c|}{$12959[\mathrm{R}(\mathrm{int})=0.1027]$} \\
\hline $\begin{array}{l}\text { Coverage of independent } \\
\text { reflections }\end{array}$ & \multicolumn{2}{|l|}{$78.0 \%$} \\
\hline Absorption correction & \multicolumn{2}{|l|}{ multi-scan } \\
\hline Max. and min. transmission & \multicolumn{2}{|l|}{0.9810 and 0.8310} \\
\hline Structure solution technique & \multicolumn{2}{|l|}{ direct methods } \\
\hline Structure solution program & \multicolumn{2}{|c|}{ SHELXS-97 (Sheldrick, 2008) } \\
\hline Refinement method & \multicolumn{2}{|c|}{ Full-matrix least-squares on $\mathrm{F}^{2}$} \\
\hline Refinement program & \multicolumn{2}{|c|}{ SHELXL-97 (Sheldrick, 2008) } \\
\hline Function minimized & \multicolumn{2}{|c|}{$\Sigma \mathrm{w}\left(\mathrm{F}_{\mathrm{o}}^{2}-\mathrm{F}_{\mathrm{c}}^{2}\right)^{2}$} \\
\hline Data / restraints / parameters & \multicolumn{2}{|l|}{12959 / 34 / 697} \\
\hline Goodness-of-fit on $F^{2}$ & \multicolumn{2}{|l|}{1.047} \\
\hline$\Delta / \sigma_{\max }$ & \multicolumn{2}{|l|}{0.001} \\
\hline Final $R$ indices & $\begin{array}{l}6844 \text { data; } \\
I>2 \sigma(I)\end{array}$ & $\mathrm{R} 1=0.0852, \mathrm{wR} 2=0.1855$ \\
\hline & all data $\quad \mathrm{R}$ & $1=0.1742, w R 2=0.2440$ \\
\hline Weighting scheme & $\begin{array}{l}\mathrm{w}=1 /\left[\sigma^{2}\left(\mathrm{~F}_{\mathrm{o}}^{2}\right)+(0.114\right. \\
\text { where } \mathrm{P}=\left(\mathrm{F}_{\mathrm{o}}^{2}+2 \mathrm{~F}_{\mathrm{c}}^{2}\right) /\end{array}$ & $\left.41 \mathrm{P})^{2}+0.0000 \mathrm{P}\right]$ \\
\hline Extinction coefficient & $0.0124(6)$ & \\
\hline Largest diff. peak and hole & 1.184 and $-1.780 \mathrm{e} \AA$ & \\
\hline R.M.S. deviation from mean & $0.348 \mathrm{e}^{-3}$ & \\
\hline
\end{tabular}


Table A8-2 Atomic coordinates and equivalent isotropic displacement parameters $\left(\AA^{2}\right)$ for rac-47. $\mathrm{U}(\mathrm{eq})$ is defined as one third of the trace of the orthogonalized $U_{\mathrm{ij}}$ tensor.

\begin{tabular}{|c|c|c|c|c|}
\hline & $\mathbf{x} / \mathbf{a}$ & $y / b$ & $\mathbf{z} / \mathbf{c}$ & $\mathrm{U}(\mathbf{e q})$ \\
\hline $\mathrm{Pd} 1$ & $0.65907(7)$ & $0.184285(16)$ & $0.84419(5)$ & $0.0226(2)$ \\
\hline $\mathrm{Pd} 2$ & $0.73905(7)$ & $0.100677(16)$ & $0.68387(5)$ & $0.0208(2)$ \\
\hline $\mathrm{C} 1$ & $0.8962(8)$ & $0.2156(2)$ & $0.8120(7)$ & $0.029(2)$ \\
\hline $\mathrm{C} 2$ & $0.9630(9)$ & $0.2387(2)$ & $0.7762(7)$ & $0.028(2)$ \\
\hline $\mathrm{C} 3$ & $0.8960(9)$ & $0.2613(2)$ & $0.6990(7)$ & $0.026(2)$ \\
\hline $\mathrm{C} 4$ & $0.9614(11)$ & $0.2873(2)$ & $0.6680(8)$ & $0.037(3)$ \\
\hline $\mathrm{C} 5$ & $0.8913(12)$ & $0.3093(3)$ & $0.5954(9)$ & $0.048(3)$ \\
\hline C6 & $0.7512(12)$ & $0.3069(3)$ & $0.5468(9)$ & $0.047(3)$ \\
\hline $\mathrm{C} 7$ & $0.6869(10)$ & $0.2816(2)$ & $0.5757(8)$ & $0.034(2)$ \\
\hline $\mathrm{C} 8$ & $0.7570(10)$ & $0.2591(2)$ & $0.6528(7)$ & $0.028(2)$ \\
\hline C9 & $0.6907(8)$ & $0.2328(2)$ & $0.6878(6)$ & $0.0201(19)$ \\
\hline $\mathrm{C} 10$ & $0.5411(9)$ & $0.2272(2)$ & $0.6326(7)$ & $0.024(2)$ \\
\hline $\mathrm{C} 11$ & $0.5127(8)$ & $0.2065(2)$ & $0.5285(6)$ & $0.024(2)$ \\
\hline $\mathrm{C} 12$ & $0.3682(10)$ & $0.2095(2)$ & $0.4587(7)$ & $0.027(2)$ \\
\hline $\mathrm{C} 13$ & $0.3070(9)$ & $0.1827(2)$ & $0.3819(7)$ & $0.027(2)$ \\
\hline $\mathrm{C} 14$ & $0.1701(9)$ & $0.1844(2)$ & $0.3250(7)$ & $0.030(2)$ \\
\hline $\mathrm{C} 15$ & $0.1060(10)$ & $0.1595(2)$ & $0.2548(8)$ & $0.040(3)$ \\
\hline $\mathrm{C} 16$ & $0.1813(11)$ & $0.1330(3)$ & $0.2437(8)$ & $0.046(3)$ \\
\hline $\mathrm{C} 17$ & $0.3132(11)$ & $0.1312(3)$ & $0.2980(8)$ & $0.042(3)$ \\
\hline $\mathrm{C} 18$ & $0.3795(10)$ & $0.1560(2)$ & $0.3682(7)$ & $0.034(2)$ \\
\hline C19 & $0.3349(9)$ & $0.1823(2)$ & $0.6630(7)$ & $0.024(2)$ \\
\hline $\mathrm{C} 20$ & $0.3550(10)$ & $0.1518(2)$ & $0.6251(7)$ & $0.030(2)$ \\
\hline $\mathrm{C} 21$ & $0.2497(10)$ & $0.1314(2)$ & $0.5729(7)$ & $0.031(2)$ \\
\hline $\mathrm{C} 22$ & $0.1229(9)$ & $0.1415(2)$ & $0.5604(7)$ & $0.030(2)$ \\
\hline $\mathrm{C} 23$ & $0.1023(10)$ & $0.1718(2)$ & $0.5993(7)$ & $0.032(2)$ \\
\hline $\mathrm{C} 24$ & $0.2081(8)$ & $0.1922(2)$ & $0.6496(7)$ & $0.024(2)$ \\
\hline $\mathrm{C} 25$ & $0.4161(8)$ & $0.2431(2)$ & $0.7849(7)$ & $0.023(2)$ \\
\hline $\mathrm{C} 26$ & $0.4330(10)$ & $0.2431(2)$ & $0.8933(8)$ & $0.032(2)$ \\
\hline $\mathrm{C} 27$ & $0.3880(10)$ & $0.2701(2)$ & $0.9345(8)$ & $0.034(2)$ \\
\hline $\mathrm{C} 28$ & $0.3320(10)$ & $0.2964(2)$ & $0.8720(8)$ & $0.036(2)$ \\
\hline $\mathrm{C} 29$ & $0.3166(9)$ & $0.2959(2)$ & $0.7651(8)$ & $0.032(2)$ \\
\hline $\mathrm{C} 30$ & $0.3563(8)$ & $0.2697(2)$ & $0.7211(7)$ & $0.029(2)$ \\
\hline $\mathrm{C} 31$ & $0.0156(9)$ & $0.1244(2)$ & $0.7897(7)$ & $0.025(2)$ \\
\hline C32 & $0.1462(8)$ & $0.1236(2)$ & $0.8573(7)$ & $0.0220(19)$ \\
\hline $\mathrm{C} 33$ & $0.1860(9)$ & $0.1021(2)$ & $0.9457(7)$ & $0.023(2)$ \\
\hline C34 & $0.3208(10)$ & $0.0993(2)$ & $0.0155(7)$ & $0.031(2)$ \\
\hline $\mathrm{C} 35$ & $0.3537(9)$ & $0.0775(2)$ & $0.0972(7)$ & $0.027(2)$ \\
\hline $\mathrm{C} 36$ & $0.2563(9)$ & $0.0578(2)$ & $0.1161(7)$ & $0.024(2)$ \\
\hline C37 & $0.1257(9)$ & $0.0601(2)$ & $0.0505(7)$ & $0.023(2)$ \\
\hline $\mathrm{C} 38$ & $0.0877(8)$ & $0.0818(2)$ & $0.9621(6)$ & $0.0196(19)$ \\
\hline C39 & $0.9556(9)$ & $0.0838(2)$ & $0.8891(7)$ & $0.023(2)$ \\
\hline
\end{tabular}




\begin{tabular}{lllll}
\hline & $\mathbf{x} / \mathbf{a}$ & $\mathbf{y} / \mathbf{b}$ & $\mathbf{z} / \mathbf{c}$ & $\mathbf{U}(\mathbf{e q})$ \\
\hline $\mathrm{C} 40$ & $0.8472(8)$ & $0.0638(2)$ & $0.9069(6)$ & $0.0214(19)$ \\
$\mathrm{C} 41$ & $0.7953(9)$ & $0.0822(2)$ & $0.9867(6)$ & $0.024(2)$ \\
$\mathrm{C} 42$ & $0.7849(9)$ & $0.0598(2)$ & $0.0737(7)$ & $0.026(2)$ \\
$\mathrm{C} 43$ & $0.7399(8)$ & $0.0749(2)$ & $0.1583(7)$ & $0.0213(19)$ \\
$\mathrm{C} 44$ & $0.7380(10)$ & $0.0547(2)$ & $0.2443(7)$ & $0.035(2)$ \\
$\mathrm{C} 45$ & $0.6996(9)$ & $0.0682(3)$ & $0.3262(7)$ & $0.037(3)$ \\
$\mathrm{C} 46$ & $0.6658(10)$ & $0.1012(3)$ & $0.3254(8)$ & $0.037(2)$ \\
$\mathrm{C} 47$ & $0.6667(9)$ & $0.1207(2)$ & $0.2403(7)$ & $0.032(2)$ \\
$\mathrm{C} 48$ & $0.7045(9)$ & $0.1081(2)$ & $0.1574(7)$ & $0.028(2)$ \\
$\mathrm{C} 49$ & $0.5632(9)$ & $0.0501(2)$ & $0.7989(7)$ & $0.024(2)$ \\
$\mathrm{C} 50$ & $0.5513(10)$ & $0.0218(2)$ & $0.8512(7)$ & $0.032(2)$ \\
$\mathrm{C} 51$ & $0.4314(10)$ & $0.0160(2)$ & $0.8692(7)$ & $0.034(2)$ \\
$\mathrm{C} 52$ & $0.3282(10)$ & $0.0378(2)$ & $0.8368(7)$ & $0.036(2)$ \\
$\mathrm{C} 53$ & $0.3429(10)$ & $0.0664(2)$ & $0.7846(8)$ & $0.037(2)$ \\
$\mathrm{C} 54$ & $0.4587(9)$ & $0.0727(2)$ & $0.7661(7)$ & $0.027(2)$ \\
$\mathrm{C} 55$ & $0.7553(8)$ & $0.0190(2)$ & $0.7259(6)$ & $0.0214(19)$ \\
$\mathrm{C} 56$ & $0.6524(9)$ & $0.0032(2)$ & $0.6451(7)$ & $0.030(2)$ \\
$\mathrm{C} 57$ & $0.6743(11)$ & $0.9743(2)$ & $0.6008(8)$ & $0.040(3)$ \\
$\mathrm{C} 58$ & $0.8018(11)$ & $0.9615(3)$ & $0.6376(7)$ & $0.039(3)$ \\
$\mathrm{C} 59$ & $0.9058(9)$ & $0.9769(2)$ & $0.7149(7)$ & $0.029(2)$ \\
$\mathrm{C} 60$ & $0.8820(9)$ & $0.0062(2)$ & $0.7589(7)$ & $0.029(2)$ \\
O3 & $0.983(2)$ & $0.0061(3)$ & $0.4843(13)$ & $0.044(4)$ \\
$\mathrm{C} 61$ & $0.984(3)$ & $0.0573(5)$ & $0.573(2)$ & $0.054(7)$ \\
$\mathrm{C} 62$ & $0.063(2)$ & $0.0276(5)$ & $0.5698(15)$ & $0.043(5)$ \\
$\mathrm{C} 63$ & $0.047(2)$ & $0.9749(5)$ & $0.4830(18)$ & $0.052(5)$ \\
$\mathrm{C} 64$ & $0.958(3)$ & $0.9535(6)$ & $0.398(2)$ & $0.055(7)$ \\
$\mathrm{C} 11$ & $0.5272(2)$ & $0.15328(5)$ & $0.91082(18)$ & $0.0306(6)$ \\
$\mathrm{C} 25$ & $0.8557(2)$ & $0.16515(6)$ & $0.98147(19)$ & $0.0334(6)$ \\
$\mathrm{C} 13$ & $0.7672(2)$ & $0.14699(5)$ & $0.58532(17)$ & $0.0252(5)$ \\
$\mathrm{C} 14$ & $0.5442(2)$ & $0.08774(5)$ & $0.54986(17)$ & $0.0276(5)$ \\
$\mathrm{N} 1$ & $0.7581(7)$ & $0.21360(17)$ & $0.7699(5)$ & $0.0228(17)$ \\
$\mathrm{N} 2$ & $0.9214(7)$ & $0.10388(17)$ & $0.8042(5)$ & $0.0206(16)$ \\
$\mathrm{O} 1$ & $0.3061(6)$ & $0.23400(15)$ & $0.4641(5)$ & $0.0300(15)$ \\
O2 & $0.8115(6)$ & $0.03044(14)$ & $0.0757(5)$ & $0.0311(15)$ \\
$\mathrm{P} 1$ & $0.4794(2)$ & $0.20794(6)$ & $0.73135(18)$ & $0.0226(5)$ \\
$\mathrm{P} 2$ & $0.7162(2)$ & $0.05771(5)$ & $0.77583(18)$ & $0.0214(5)$ \\
\hline & & & & \\
\end{tabular}


Table A9-1 Crystal data and structure refinement for $\left(R, R_{C}, R_{P}\right)-50$

\begin{tabular}{|c|c|c|}
\hline Chemical formula & \multicolumn{2}{|c|}{$\mathrm{C}_{46} \mathrm{H}_{44} \mathrm{Cl}_{3} \mathrm{~N}_{2} \mathrm{O}_{6} \mathrm{PPd}$} \\
\hline Formula weight & \multicolumn{2}{|l|}{964.55} \\
\hline Temperature & \multicolumn{2}{|l|}{$153(2) \mathrm{K}$} \\
\hline Wavelength & \multicolumn{2}{|l|}{$0.71073 \AA$} \\
\hline Crystal size & \multicolumn{2}{|c|}{$0.040 \times 0.100 \times 0.400 \mathrm{~mm}$} \\
\hline Crystal habit & \multicolumn{2}{|l|}{ colorless plate } \\
\hline Crystal system & \multicolumn{2}{|l|}{ orthorhombic } \\
\hline Space group & \multicolumn{2}{|l|}{ P 212121} \\
\hline \multirow[t]{3}{*}{ Unit cell dimensions } & $a=10.451(4) \AA$ & $\alpha=90^{\circ}$ \\
\hline & $\mathrm{b}=13.846(6) \AA$ & $\beta=90^{\circ}$ \\
\hline & $\mathrm{c}=30.951(12) \AA$ & $\gamma=90^{\circ}$ \\
\hline Volume & \multicolumn{2}{|l|}{ 4479.(3) $\AA^{3}$} \\
\hline $\mathbf{Z}$ & \multicolumn{2}{|l|}{4} \\
\hline Density (calculated) & \multicolumn{2}{|l|}{$1.430 \mathrm{~g} / \mathrm{cm}^{3}$} \\
\hline Absorption coefficient & \multicolumn{2}{|l|}{$0.678 \mathrm{~mm}^{-1}$} \\
\hline $\mathbf{F}(\mathbf{0 0 0})$ & \multicolumn{2}{|l|}{1976} \\
\hline Theta range for data collection & \multicolumn{2}{|l|}{1.61 to $26.37^{\circ}$} \\
\hline Index ranges & \multicolumn{2}{|c|}{$-12<=\mathrm{h}<=8,-17<=\mathrm{k}<=17,-33<=1<=38$} \\
\hline Reflections collected & \multicolumn{2}{|c|}{18164} \\
\hline Independent reflections & \multicolumn{2}{|c|}{$9054[\mathrm{R}(\mathrm{int})=0.0793]$} \\
\hline $\begin{array}{l}\text { Coverage of independent } \\
\text { reflections }\end{array}$ & \multicolumn{2}{|l|}{$99.4 \%$} \\
\hline Absorption correction & \multicolumn{2}{|l|}{ multi-scan } \\
\hline Max. and min. transmission & \multicolumn{2}{|l|}{0.9734 and 0.7731} \\
\hline Structure solution technique & \multicolumn{2}{|l|}{ direct methods } \\
\hline Structure solution program & \multicolumn{2}{|c|}{ SHELXS-97 (Sheldrick, 2008) } \\
\hline Refinement method & \multicolumn{2}{|c|}{ Full-matrix least-squares on $\mathrm{F}^{2}$} \\
\hline Refinement program & \multicolumn{2}{|c|}{ SHELXL-97 (Sheldrick, 2008) } \\
\hline Function minimized & \multicolumn{2}{|l|}{$\Sigma \mathrm{w}\left(\mathrm{F}_{\mathrm{o}}^{2}-\mathrm{F}_{\mathrm{c}}^{2}\right)^{2}$} \\
\hline Data / restraints / parameters & \multicolumn{2}{|l|}{9054 / 177 / 593} \\
\hline Goodness-of-fit on $F^{2}$ & \multicolumn{2}{|l|}{0.996} \\
\hline$\Delta / \sigma_{\max }$ & \multicolumn{2}{|l|}{0.001} \\
\hline Final $\mathbf{R}$ indices & $\begin{array}{l}5709 \text { data; } \\
\mathrm{I}>2 \sigma(\mathrm{I})\end{array}$ & $\mathrm{R} 1=0.0732, \mathrm{wR} 2=0.1582$ \\
\hline & all data & $\mathrm{R} 1=0.1248, w \mathrm{R} 2=0.1958$ \\
\hline Weighting scheme & $\begin{array}{l}\mathrm{w}=1 /\left[\sigma^{2}\left(\mathrm{~F}_{\mathrm{o}}^{2}\right)+(0.0\right. \\
\text { where } \mathrm{P}=\left(\mathrm{F}_{\mathrm{o}}^{2}+2 \mathrm{~F}_{\mathrm{c}}^{2}\right.\end{array}$ & $\begin{array}{l}\left.953 \mathrm{P})^{2}+0.0000 \mathrm{P}\right] \\
\left.{ }^{2}\right) / 3\end{array}$ \\
\hline Absolute structure parameter & $-0.0(1)$ & \\
\hline Extinction coefficient & $0.0162(9)$ & \\
\hline Largest diff. peak and hole & 0.849 and $-1.269 \mathrm{e}$ & $\AA^{-3}$ \\
\hline R.M.S. deviation from mean & $0.196 \mathrm{e}^{-3}$ & \\
\hline
\end{tabular}


Table A9-2 Atomic coordinates and equivalent isotropic displacement parameters $\left(\AA^{2}\right)$ for $\left(R, R_{C}, R_{P}\right)-50 . U(e q)$ is defined as one third of the trace of the orthogonalized $U_{\mathrm{ij}}$ tensor.

\begin{tabular}{|c|c|c|c|c|}
\hline & $\mathbf{x} / \mathbf{a}$ & $y / b$ & $\mathbf{z} / \mathbf{c}$ & $\mathrm{U}(\mathbf{e q})$ \\
\hline $\mathrm{Pd} 1$ & $0.13563(6)$ & $0.54603(4)$ & $0.86848(2)$ & $0.0314(2)$ \\
\hline $\mathrm{C} 1$ & $0.2687(9)$ & $0.6148(6)$ & $0.9034(3)$ & $0.031(2)$ \\
\hline $\mathrm{C} 2$ & $0.2640(9)$ & $0.6356(6)$ & $0.9488(3)$ & $0.036(2)$ \\
\hline $\mathrm{C} 3$ & $0.3481(9)$ & $0.6955(6)$ & $0.9682(3)$ & $0.037(2)$ \\
\hline $\mathrm{C} 4$ & $0.4481(9)$ & $0.7397(6)$ & $0.9450(3)$ & $0.031(2)$ \\
\hline $\mathrm{C} 5$ & $0.5359(9)$ & $0.8025(6)$ & $0.9637(3)$ & $0.036(2)$ \\
\hline C6 & $0.6357(10)$ & $0.8411(6)$ & $0.9409(3)$ & $0.0323(19)$ \\
\hline $\mathrm{C} 7$ & $0.6468(9)$ & $0.8215(6)$ & $0.8972(3)$ & $0.039(2)$ \\
\hline $\mathrm{C} 8$ & $0.5620(8)$ & $0.7603(6)$ & $0.8766(3)$ & $0.033(2)$ \\
\hline C9 & $0.4577(8)$ & $0.7184(6)$ & $0.8999(3)$ & $0.028(2)$ \\
\hline $\mathrm{C} 10$ & $0.3650(9)$ & $0.6578(6)$ & $0.8802(3)$ & $0.032(2)$ \\
\hline $\mathrm{C} 11$ & $0.3634(10)$ & $0.6370(6)$ & $0.8312(3)$ & $0.036(2)$ \\
\hline $\mathrm{C} 12$ & $0.4379(10)$ & $0.5444(8)$ & $0.8213(3)$ & $0.051(3)$ \\
\hline $\mathrm{C} 13$ & $0.1692(10)$ & $0.7307(6)$ & $0.8182(3)$ & $0.047(3)$ \\
\hline $\mathrm{C} 14$ & $0.2087(11)$ & $0.5884(8)$ & $0.7732(3)$ & $0.050(3)$ \\
\hline $\mathrm{C} 15$ & $0.9037(10)$ & $0.5287(7)$ & $0.8052(3)$ & $0.042(2)$ \\
\hline $\mathrm{C} 16$ & $0.7972(10)$ & $0.4939(7)$ & $0.7875(3)$ & $0.043(3)$ \\
\hline $\mathrm{C} 17$ & $0.7512(10)$ & $0.4020(7)$ & $0.7991(3)$ & $0.037(2)$ \\
\hline C18 & $0.6389(11)$ & $0.3604(7)$ & $0.7822(3)$ & $0.041(2)$ \\
\hline C19 & $0.5970(9)$ & $0.2719(7)$ & $0.7952(3)$ & $0.042(3)$ \\
\hline $\mathrm{C} 20$ & $0.6650(9)$ & $0.2222(7)$ & $0.8262(3)$ & $0.042(3)$ \\
\hline $\mathrm{C} 21$ & $0.7716(9)$ & $0.2590(7)$ & $0.8443(3)$ & $0.035(2)$ \\
\hline $\mathrm{C} 22$ & $0.8189(8)$ & $0.3494(6)$ & $0.8313(3)$ & $0.030(2)$ \\
\hline $\mathrm{C} 23$ & $0.9322(9)$ & $0.3926(6)$ & $0.8483(3)$ & $0.031(2)$ \\
\hline $\mathrm{C} 24$ & $0.0110(9)$ & $0.3428(6)$ & $0.8823(3)$ & $0.033(2)$ \\
\hline $\mathrm{C} 25$ & $0.1155(9)$ & $0.2774(6)$ & $0.8616(3)$ & $0.032(2)$ \\
\hline $\mathrm{C} 26$ & $0.1603(9)$ & $0.1994(6)$ & $0.8916(3)$ & $0.031(2)$ \\
\hline $\mathrm{C} 27$ & $0.2582(9)$ & $0.1291(6)$ & $0.8751(3)$ & $0.035(2)$ \\
\hline $\mathrm{C} 28$ & $0.3038(9)$ & $0.1333(7)$ & $0.8327(3)$ & $0.037(2)$ \\
\hline $\mathrm{C} 29$ & $0.3897(9)$ & $0.0664(6)$ & $0.8187(3)$ & $0.040(2)$ \\
\hline $\mathrm{C} 30$ & $0.4306(10)$ & $0.9937(7)$ & $0.8458(4)$ & $0.048(3)$ \\
\hline $\mathrm{C} 31$ & $0.3870(11)$ & $0.9874(7)$ & $0.8875(4)$ & $0.057(3)$ \\
\hline $\mathrm{C} 32$ & $0.2989(10)$ & $0.0530(8)$ & $0.9020(3)$ & $0.052(3)$ \\
\hline C33 & $0.9122(8)$ & $0.4775(5)$ & $0.9418(3)$ & $0.028(2)$ \\
\hline C34 & $0.8383(9)$ & $0.4112(6)$ & $0.9646(3)$ & $0.036(2)$ \\
\hline $\mathrm{C} 35$ & $0.7175(9)$ & $0.4337(8)$ & $0.9801(3)$ & $0.043(3)$ \\
\hline $\mathrm{C} 36$ & $0.6679(11)$ & $0.5263(8)$ & $0.9723(4)$ & $0.058(3)$ \\
\hline $\mathrm{C} 37$ & $0.7419(10)$ & $0.5937(8)$ & $0.9504(4)$ & $0.054(3)$ \\
\hline C38 & $0.8620(10)$ & $0.5693(6)$ & $0.9356(3)$ & $0.040(2)$ \\
\hline
\end{tabular}




\begin{tabular}{lllll}
\hline & $\mathbf{x} / \mathbf{a}$ & $\mathbf{y} / \mathbf{b}$ & $\mathbf{z} / \mathbf{c}$ & $\mathbf{U}(\mathbf{e q})$ \\
\hline $\mathrm{C} 39$ & $0.1618(9)$ & $0.4053(6)$ & $0.9635(3)$ & $0.035(2)$ \\
$\mathrm{C} 40$ & $0.1235(9)$ & $0.4198(6)$ & $0.0067(3)$ & $0.035(2)$ \\
$\mathrm{C} 41$ & $0.2060(9)$ & $0.4002(7)$ & $0.0414(3)$ & $0.044(3)$ \\
$\mathrm{C} 42$ & $0.3262(10)$ & $0.3690(7)$ & $0.0338(3)$ & $0.044(3)$ \\
$\mathrm{C} 43$ & $0.3694(10)$ & $0.3540(6)$ & $0.9912(3)$ & $0.039(2)$ \\
$\mathrm{C} 44$ & $0.2895(9)$ & $0.3729(6)$ & $0.9560(3)$ & $0.037(2)$ \\
$\mathrm{C} 45$ & $0.4513(10)$ & $0.3356(8)$ & $0.9014(4)$ & $0.063(4)$ \\
$\mathrm{C} 46$ & $0.996(3)$ & $0.4401(15)$ & $0.6375(6)$ & $0.109(5)$ \\
$\mathrm{Cl} 2$ & $0.9970(15)$ & $0.3920(11)$ & $0.5862(4)$ & $0.186(5)$ \\
$\mathrm{Cl} 3$ & $0.0808(6)$ & $0.5418(4)$ & $0.6532(3)$ & $0.109(3)$ \\
$\mathrm{C} 46 \mathrm{~A}$ & $0.980(9)$ & $0.430(4)$ & $0.6528(12)$ & $0.099(8)$ \\
$\mathrm{Cl} 2 \mathrm{~A}$ & $0.017(3)$ & $0.525(2)$ & $0.6852(9)$ & $0.159(9)$ \\
$\mathrm{Cl} 3 \mathrm{~A}$ & $0.000(2)$ & $0.4082(15)$ & $0.5991(8)$ & $0.080(5)$ \\
$\mathrm{Cl} 1$ & $0.2522(3)$ & $0.3001(2)$ & $0.73386(9)$ & $0.0556(7)$ \\
O3 & $0.3355(8)$ & $0.2182(5)$ & $0.7311(2)$ & $0.059(2)$ \\
O4 & $0.254(2)$ & $0.3624(13)$ & $0.6998(5)$ & $0.114(7)$ \\
O5 & $0.1242(12)$ & $0.2622(11)$ & $0.7427(6)$ & $0.094(6)$ \\
O6 & $0.2849(14)$ & $0.3469(9)$ & $0.7749(3)$ & $0.053(4)$ \\
O4A & $0.1570(18)$ & $0.2859(14)$ & $0.7008(7)$ & $0.086(7)$ \\
O5A & $0.197(3)$ & $0.3313(16)$ & $0.7724(5)$ & $0.090(7)$ \\
O6A & $0.325(2)$ & $0.3812(9)$ & $0.7158(6)$ & $0.068(7)$ \\
N1 & $0.2210(7)$ & $0.6311(5)$ & $0.8185(2)$ & $0.0365(19)$ \\
N2 & $0.9771(7)$ & $0.4793(5)$ & $0.8356(2)$ & $0.0342(18)$ \\
O1 & $0.1184(6)$ & $0.1916(4)$ & $0.9284(2)$ & $0.0390(15)$ \\
O2 & $0.3213(6)$ & $0.3615(5)$ & $0.9136(2)$ & $0.0393(16)$ \\
P1 & $0.0654(2)$ & $0.44389(16)$ & $0.91873(7)$ & $0.0297(5)$ \\
\hline & & & & \\
\hline
\end{tabular}

